Szegedi Tudományegyetem

Természettudományi és Informatikai Kar

Földtudományok Doktori Iskola

Gazdaság- és Társadalomföldrajz Tanszék

\title{
AZ ALFÖLD VIDÉKTURIZMUSÁNAK FÖLDRAJZI JELLEMZŐI
}

Doktori (Ph.D.) értekezés

\section{Gulyás Péter}

Témavezető:

Dr. Csatári Bálint

egyetemi docens

Szeged

2016. 


\section{TARTALOMJEGYZÉK}

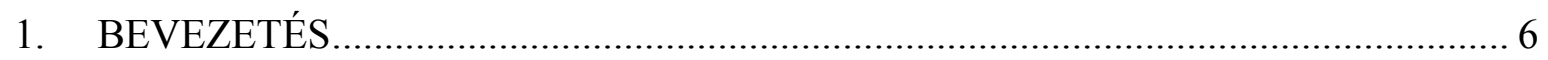

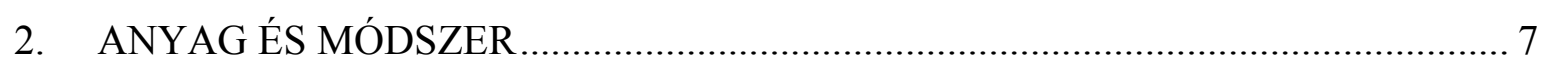

2.1. Az értekezés felépítése, a vizsgálatok időintervalluma ......................................... 7

2.2. A vizsgált terület lehatárolása, az értekezés célkitűzései, főbb kérdések ................ 8

2.3. Az értekezés elkészítése során alkalmazott módszerek ......................................... 9

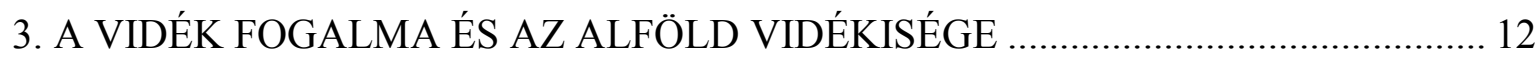

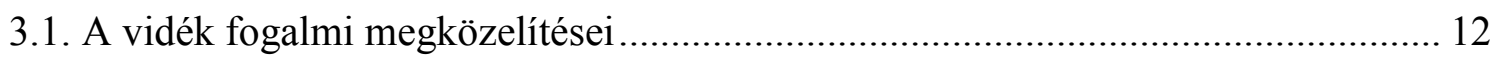

3.2. A hazai vidéki térségek tipizálása és az Alföld vidékisége ...................................... 14

4. A TURIZMUS ÉS A VIDÉKTURIZMUS FÖLDRAJZI ÉRTELMEZÉSE ................... 19

4.1. A turizmusföldrajz és a vidékföldrajz kapcsolata .................................................. 19

4.2. A rurális turizmus értelmezése, nemzetközi megközelítései.................................... 24

4.3. Az Integrált Rurális Turizmus koncepciójáról ………………………………..... 28

4.4. A rurális turizmus fogalmának hazai megközelítései............................................... 29

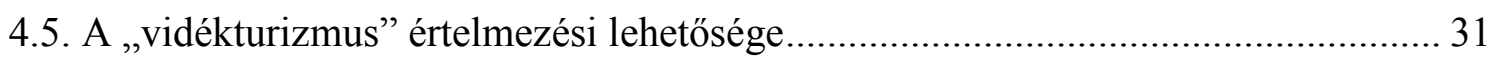

5. A VIDÉKGAZDASÁG ÉS A TURIZMUS ÖSSZEFÜGGÉSEI .................................. 34

5.1. A regionális fejlödési modellek érvényesülése vidéki térségekben .......................... 34

5.2. A helyi erőforrások és a vidékgazdaság ............................................................ 37

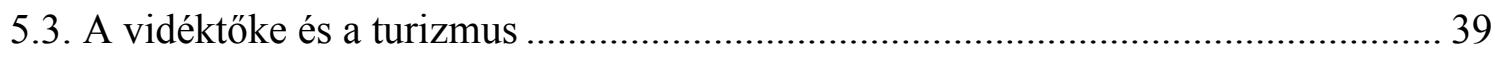

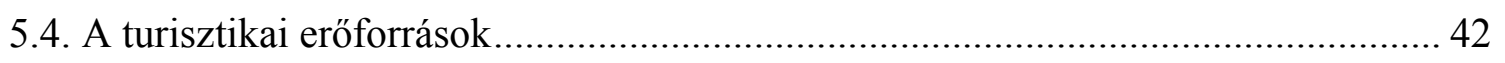

5.5. A kultúra szerepe a vidékgazdaság fejlődésében, a kultúragazdaság koncepciója .. 44

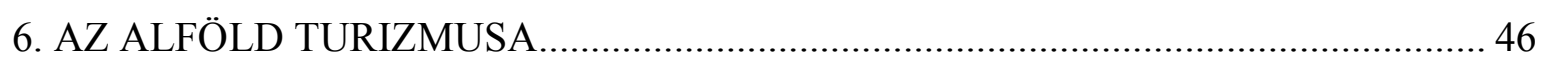

6.1. A vidéki területek turizmusának története Magyarországon...................................... 46

6.2. Falusi turizmus a rendszerváltást követően............................................................ 49

6.3. Az Alföld turizmusa - a vonzerők alapján ............................................................. 52

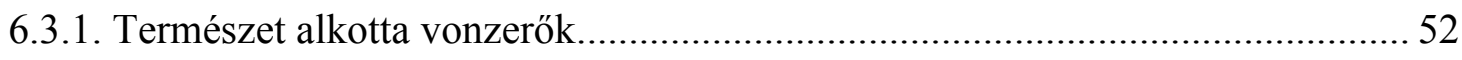

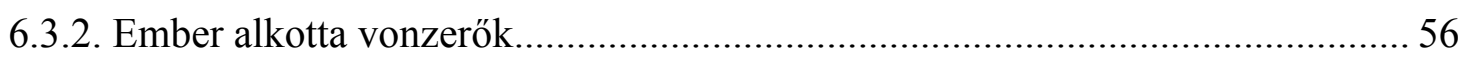

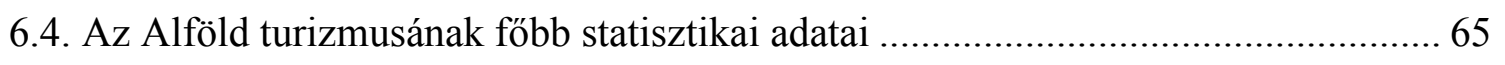

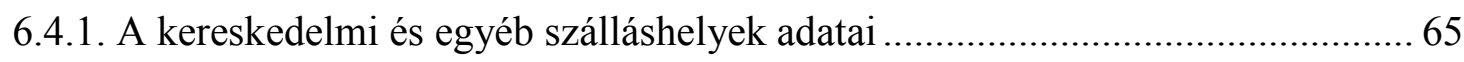

6.4.2. Nem üzleti céllal üzemeltetett közösségi és szabadidős szálláshelyek az

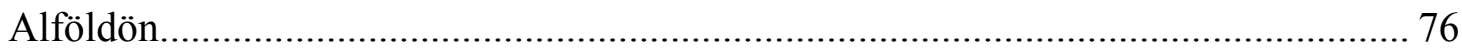

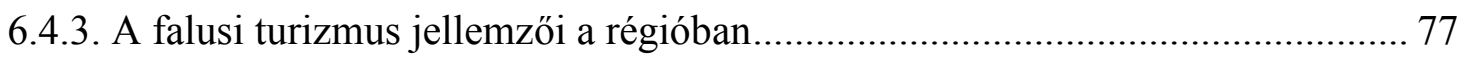


6.4.4. A falusi turizmus térbeli sürüsödései 82

6.4.5. Falusi szálláshelyek minőségi kategóriái ......................................................... 84

6.4.6. Kísérlet a vidékturizmus teljesítményének mérésére ....................................... 86

6.5. Az Alföld turizmusa - a benne részt vevő szakmai szereplők megkérdezésével ..... 89

6.5.1. Az Alföld turizmusának jellemzői az összes megkérdezett szerint ................... 90

6.5.2. A turizmus jellemzői a falusi vendégfogadók szerint ..................................... 97

6.5.3. Az alföldi vidékturizmus kiemelt térségeinek sajátosságai a kérdőívek alapján

6.6. A vidékturizmus alföldi sajátosságainak megjelenése turisztikai témájú weboldalakon.

6.6.1. A turisztikai szektort müködtető szereplők honlapjainak jellemzői

6.6.2. Turisztikai desztinációkat bemutató honlapok jellemzői

7. ÖSSZEFOGLALÁS, KONKLÚZIÓK, JAVASLATOK 


\section{ÁBRAJEGYZÉK}

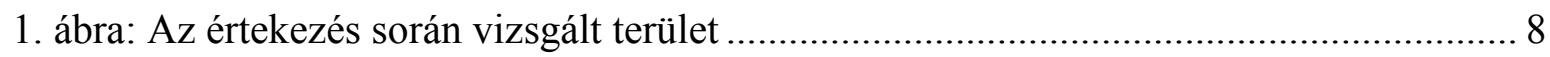

2. ábra: A magyarországi járások komplex típusai ....................................................... 16

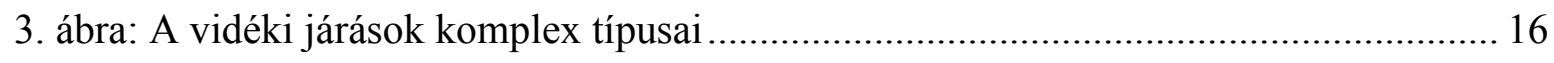

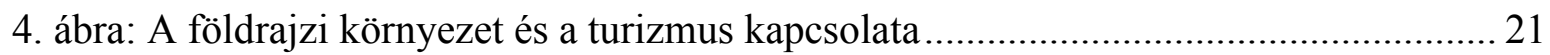

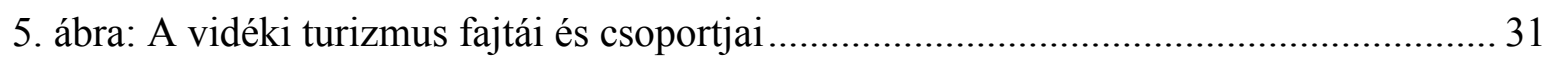

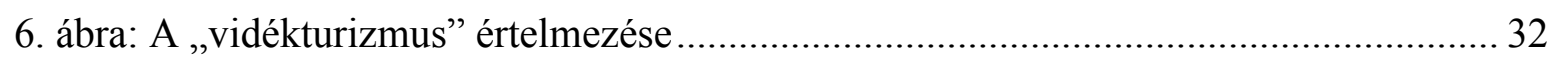

7. ábra: Az erőforrások, a „vidéktőke” és a turizmus kapcsolata a vidéki térségekben ....... 42

8. ábra: Fürdőtelepülések és vendégéjszakák az Alföldön.............................................. 53

9. ábra: Nemzeti Parkok és Natúrparkok Magyarországon..................................................56

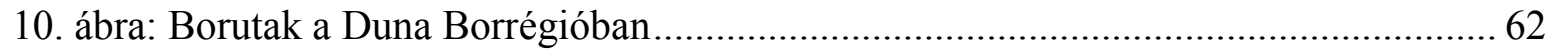

11. ábra: A lovas szolgáltatók és a vendégéjszakák száma az alföldi járásokban............... 63

12. ábra: A turizmusban érintett települések az Alföldön ................................................ 66

13. ábra: Kereskedelmi és egyéb szálláshelyek kapacitása az Alföldi járásokban .............. 69

14. ábra: Kereskedelmi és egyéb szálláshelyek kapacitása az Alföldi településeken .......... 70

15. ábra: A vendégéjszakák számának alakulása az Alföldön ......................................... 71

16. ábra: 1000 lakosra jutó vendégéjszakák az alföldi járásokban................................... 73

17. ábra: Vendégéjszakák száma kereskedelmi és egyéb szálláshelyeken az alföldi

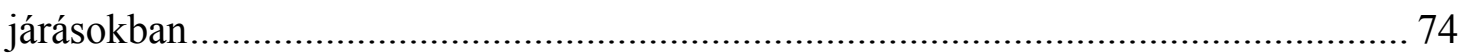

18. ábra: A falusi szállásadók és férőhelyek számának alakulása az Alföldön.................... 80

19. ábra: A falusi turizmus vendégforgalma az Alföldön ............................................. 81

20. ábra: A külföldi és belföldi vendégéjszakák aránya a falusi turizmus

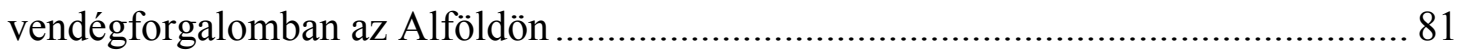

21. ábra: 1000 lakosra jutó falusi vendégéjszakák száma az Alföldön ................................ 83

22. ábra: A falusi szálláshelyeken eltöltött vendégéjszakák térbeli eloszlása...................... 84

23. ábra: Napraforgós Nemzeti Tanúsító Védjeggyel rendelkező szálláshelyek az Alföldön

24. ábra: Az Alföld belső erőforrásai az összes válaszadó szerint .................................... 92

25. ábra: A belső erőforrások fő csoportjai az alföldi járásokban ..................................... 93

26. ábra: Együttmüködés a turisztikai szakma szereplőivel és egyéb partnerekkel .............95

27. ábra: A falusi szállásadói szolgáltatás elindításának indítékai ..................................... 97

28. ábra: Az Alföld belső erőforrásai a falusi szállásadók szerint .................................... 100 
29. ábra: A turisztikai együttműködések minősége az Alföldön. 100

30. ábra: A turizmus jelentősége főbb válaszadói csoportonként 102

31. ábra: Térségi (desztinációs) honlapok minőségi kategóriái 115

\section{TÁBLÁZATOK JEGYZÉKE}

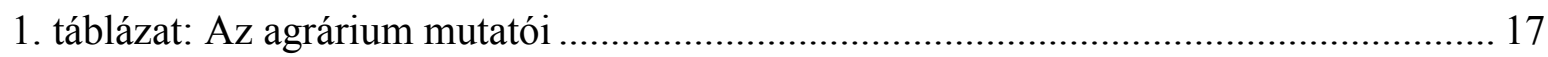

2. táblázat: A turisztikai termékek besorolása Lane szerint ............................................... 27

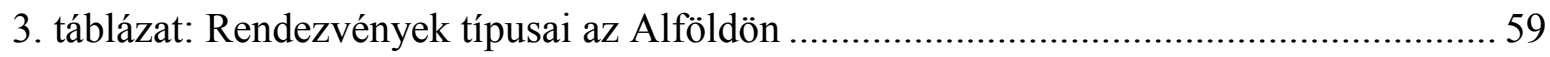

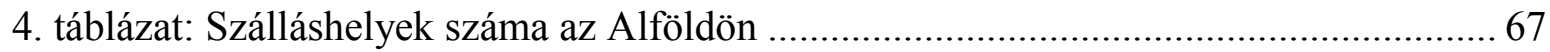

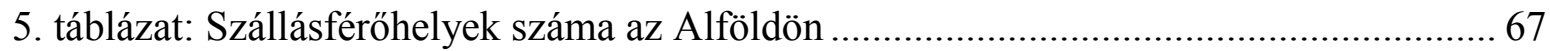

6. táblázat: Vendégéjszakák aránya szállástípusonként az Alföldön.....................72

7. táblázat: Az Alföld fö külföldi küldő országai 2011-ben és 2014-ben ............................ 76

8. táblázat: Nem üzleti céllal üzemeltetett közösségi, szabadidős szálláshelyek az Alföldi

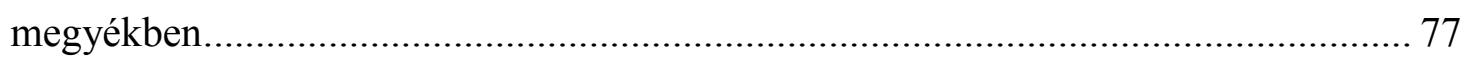

9. táblázat: Az egyéb (2009-ig magán) szállásadás adatainak változása............................. 79

10. táblázat: A vidékturizmus teljesítménye a vendégéjszakák száma alapján.................... 87

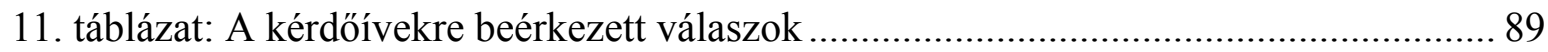

12. táblázat: A turizmus jelentőségének megítélése a jövőbeli fejlesztések kapcsán .......... 96

13. táblázat: A honlapok átlagos pontszámai főbb szolgáltatói típusonként...................... 112

14. táblázat: A szolgáltatói honlapok összpontszámainak megoszlása kategóriák szerint..112

15. táblázat: A desztinációk honlapjai kategóriák szerint. 


\section{Bevezetés}

A turizmus mára a világ egyik vezető és legdinamikusabban fejlődő ágazatává vált. Multiszektorális kapcsolódásai révén a földrajzi környezet valamennyi elemével kölcsönkapcsolatban áll. A tömeges elterjedése a geográfusokon kívül számos más tudományág (közgazdaságtan, szociológia, történelem, jog, pszichológia, stb.) müvelőinek érdeklődését is felkeltette. Noha jellegénél fogva inkább városias jelenség, az utóbbi évtizedekben egyre nagyobb jelentőségre tett szert az átalakuló vidéki térségekben is. Napjainkra a posztmodern fejlődési szakaszba jutott vidéki területeken már nem csak az élelmiszer-alapanyag termelés jellemző, hanem sokkal inkább az új vidéki funkciók aránynövekedése, a lakó-, a tájmegőrző és a turisztikai funkciók megerősödése. Számos fejlett országban a „vidékgazdaság” meghatározó ágazatává és a vidékfejlesztés egyik kulcstényezőjévé vált a helyi, belső erőforrások fenntartható hasznosítására épülő turizmus. Hazánkban az 1990-es években bekövetkezö gazdasági visszaesés az Alföldet fokozottan sújtotta, s a problémákra máig nem sikerült hathatós válaszokat adni. Sok település és kistáj ebben a régióban is a turizmusban látta a válságból való kilábalás viszonylag gyors lehetőségét. Noha az Alföld turizmusa mennyiségi és minőségi tekintetben is jelentős fejlődésen ment keresztül az utóbbi bő két évtizedben, számos megoldásra váró problémával küzd, melyeket csak alapos kutatásokra épülő tervezéssel és fejlesztéssel lehetne megoldani. E téma relevanciájához képest viszonylag kevés földrajzi szempontú tudományos kutatás látott napvilágot az elmúlt évtizedekben az Alföld turizmusáról. Ezek közül a legjelentősebbek és legátfogóbbak az Alföld kutatási programok részeként, Csordás László vezetésével készültek még az 1990-es években (CSORDÁS 1992, CSORDÁS 1999). Szintén fontos mérföldkövet jelentettek Hanusz Árpád falusi turizmusra, SzabolcsSzatmár-Bereg megye turizmusára és a Turisztikai Desztináció Menedzsment Szervezetek működésére vonatkozó kutatásai (HANUSZ - PRISTYÁK 2007, HANUSZ 2009).

Ezért úgy vélem indokolt lehet az Alföld turizmusának új, módszeres és átfogó vidék-, illetve turizmusföldrajzi elemzése, a vonzerők és a vendégforgalom különböző szempontú kapcsolatrendszerének feltárása, a turizmus adta lehetőségek különböző geográfiai és vidékgazdasági vizsgálata. Témaválasztásomnak személyes oka, hogy sokakhoz, költőkhöz, kutatókhoz hasonlóan jómagam is erőteljes érzelmi szálakkal kötődöm e tájhoz, s több mint 
egy évtizednyi turizmusban szerzett gyakorlati tapasztalataimat e módon is hasznosítani szerettem volna a régió érdeklődő közönsége számára.

\section{Anyag és módszer}

\subsection{Az értekezés felépítése, a vizsgálatok időintervalluma}

Doktori dolgozatomban arra törekszem, hogy a választott témát európai szakirodalmi kitekintéssel, az általánostól az egyedi felé haladva mutassam be. Ennek jegyében munkám során elsőként a vidék fogalmának nemzetközi és hazai értelmezéseit és a legújabb hazai vidékkutatási eredményeket ismertetem. Ezt követően feltárom a vidékföldrajz és turizmusföldrajz kapcsolatrendszerének főbb jellemzőit, valamint a vidéki területek turizmusával kapcsolatos különböző európai és hazai fogalmi megközelítéseket. Az elméleti megfontolások végén felvázolom a vidékturizmus általam használt és követett koncepcióját. A nemzetközi és hazai szakirodalom alapján értelmezem az ún. belső-, és a turisztikai erőforrásokat a vidéki területek, illetve a vidékgazdaság szempontjából. Ezután az Alföld turisztikai kínálatát és annak speciális, e régióra jellemző geográfiai elemeit mutatom be, majd szekunder kutatásaim keretében a meglévő turisztikai adatbázisokra alapozva elemzem a térség turizmusának föbb adatait, időbeli és térbeli folyamatait. Primer kutatásaim során vizsgáltam az alföldi turisztikai szakmai szereplők véleményét és hozzáállását a témához célzott, on-line kérdőíves felméréssel, valamint interneten történő megjelenésük, turisztikai kínálatuk főbb földrajzi sajátosságait.

Vizsgálataim időintervalluma a vidék fogalmával és jellemzőivel kapcsolatban, a vidékgazdaságot érintően, majd az Alföldre jellemző turisztikai folyamatok vonatkozásában általában a II. világháborútól napjainkig terjedő időszakot öleli fel. Az Alföld jelenlegi turizmusföldrajzának elemzését ennél rövidebb időtávra, az elmúlt 15 évre vonatkozóan készítettem el. 


\subsection{A vizsgált terület lehatárolása, az értekezés célkitüzései, főbb kérdések}

Értekezésemben konkrét elemzéseimet a hat alföldi megyére (Bács-Kiskun, Békés, Csongrád, Jász-Nagykun-Szolnok, Hajdú-Bihar és Szabolcs- Szatmár-Bereg megye), és további 11 alföldi térségre (Pest megyéből: ceglédi, dabasi, monori, nagykátai, nagykőrösi, ráckevei járás; Heves megyéből: füzesabonyi és hevesi járás; Borsod-Abaúj-Zemplén megyéből: mezőcsáti, mezőkövesdi és tiszaújvárosi járás), összesen 70 járásra vonatkozóan végzem el. Alapnak tehát a közigazgatási határokkal leírható természeti földrajzi síkságot tekintem, ami ebben a régióban a vidékies turisztikai kínálat alapját képezi.

\section{1. ábra: Az értekezés során vizsgált terület}

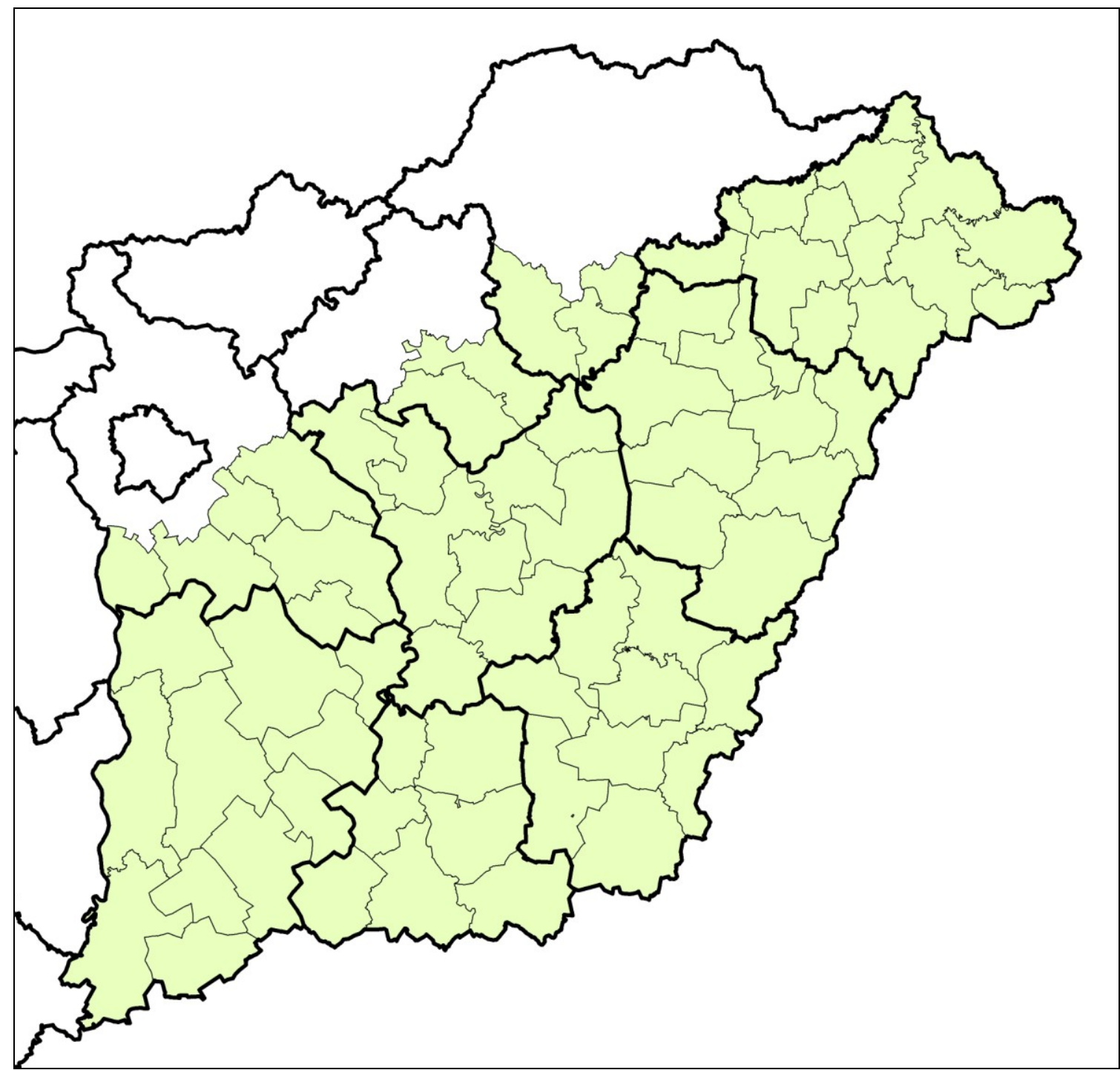

Forrás: saját szerkesztés 
Munkám során fő célkitűzésem volt, hogy elsősorban a tradícionális földrajzi szempontokat megújítva, európai kitekintéssel megvizsgáljam a vidéki tér, a vidékgazdaság és a turizmus kapcsolatrendszerét az Alföldön. Fel kívántam tárni a régió turizmusának térfolyamatait és annak változásait az elmúlt 15 évre vonatkozóan. Célom volt továbbá, hogy részletes képet rajzoljak az alföldi turizmus helyzetéről, a táj vidékiségével összefüggésben, annak speciális vonásairól és problémáiról. Kiemelt jelentőséget tulajdonítok és nagy hangsúlyt fektetek elemzéseim során az alföldi tájakra, azokra a „vidékek”-re, ahol a mérhető és jelentősnek tekinthető turisztikai folyamatok zajlanak. Munkám végén kísérletet teszek néhány javaslat megfogalmazására, amelyek a gyakorlatban is alkalmazhatók lehetnének az Alföld turizmusának jövőbeli fejlődését segítendő.

Kutatásaim során az alábbi kérdésekre kerestem a választ:

- Hogyan változott meg a turizmus szerepe a fejlett európai vidéki térségek gazdaságában a II. világháborút követően?

- Adaptálhatók-e az ott érvényes megközelítések és modellek a vidéki területek turizmusát illetően az Alföldre? Felvázolható-e egy alföldi vidékturisztikai modell?

- Melyek a turizmus fontosabb egyedi és vidékies kínálati elemei az Alföldön? Hogyan alakult az Alföld turizmusa az elmúlt 15 évben? Melyek a fő turisztikai magterületek?

- Melyek az Alföld főbb helyi és belső erőforrásai? Megvannak-e azok a társadalmi és humán erőforrások, amelyek e régióban a turizmus jövőbeli fejlődési lehetőségei szempontjából elengedhetetlenül szükségesek?

- Melyek a föbb jellemzői az alföldi turisztikai szektor internetes megjelenéseinek? Felfedezhetők-e benne, ha igen miként a vidékturizmus sajátos jegyei, speciális alföldi szolgáltatások és a vidékiség?

\subsection{Az értekezés elkészítése során alkalmazott módszerek}

Doktori értekezésem elkészítése során primer és szekunder kutatást egyaránt végeztem.

Primer kutatásaim keretében nem valószínűségi mintavételi eljárással, on-line kérdőíves felmérést készítettem az alföldi turizmust működtető szakmai szereplők (falusi szállásadók, egyéb szállásadók, kereskedelmi szálláshelyek, turisztikai szolgáltatók, turisztikai szervezetek és LEADER Helyi Akciócsoportok) körében. Az e célcsoportokra külön-külön 
specializált kérdőíveket Google ürlapokként készítettem el és küldtem szét a fentiekben felsorolt, közel 2500 szakmai szereplő e-mail címére. A válaszok behatárolhatósága okán zömmel zárt kérdéseket tettem fel, melyekre azok jellegétől függően egy vagy több választ adhattak a kérdőívet kitöltők. Több téma kapcsán (pl. belső erőforrások értékelése) a válaszadó véleményére, értékelésére voltam kíváncsi, így ezek mérésére a társadalomtudományokban széles körben alkalmazott Likert-skálát használtam. A beérkező válaszokat a Google alkalmazás táblázatos formában rögzítette. A Microsoft Excel formátumban kiexportált válaszokat SPSS szoftverrel rendeztem és értékeltem ki felhasználva kereszttábla elemzés és a korreláció számítás módszerét.

Kutatásaim során a tartalomelemzés metódusát alkalmazva az alföldi turisztikai szektort működtető szakmai szereplők honlapjainak elemzését végeztem el. Összesen 294 alföldi turisztikai szolgáltató (szálláshelyek, fürdők, lovas tanyák, vendéglátóhelyek, programszervezők) honlapját tekintettem át, továbbá a vizsgált 70 járás térségi szintü interneten történő megjelenését elemeztem a kínált szolgáltatások egyedisége, vidékisége, „alföldisége” mentén; a szakmai szereplőkkel való együttmüködésüket értékelve, továbbá a külső megjelenésük, komplexitásuk, rendezettségük, valamint földrajzi tartalmuk tekintetében. A honlapokat ezen szempontok szerint 10-es skálán pontoztam, majd objektumonként és szolgáltatói típusonként összesítettem a kapott értékeket. Értékelésüket Microsoft Excel és SPSS Statistics 22 szoftverekkel végeztem kereszttábla elemzések segítségével.

Szekunder kutatásaim egyrészt a témám szempontjából releváns hazai és nemzetközi szakirodalmak feldolgozására terjedtek ki, melynek során a forrásértékelés és az összehasonlító elemzés metódusát alkalmaztam. Munkám során felhasználtam a releváns magyar és angol nyelvü szakkönyveket, valamint a hazai és külföldi szakmai folyóiratok (A Falu, Területi Statisztika, Tér és Társadalom, Turizmus Bulletin, Gazdálkodás, Falusi Turizmus Tájékoztató, Magyar Tudomány, Valóság, valamint Sociologia Ruralis, Journal of Rural Studies, Journal of Sustainable Tourism, Annals of Tourism Research) nyomtatott vagy interneten elérhető verzióit. Áttekintettem a turizmushoz kapcsolódó hazai jogszabályokat (a magánszálláshelyek idegenforgalmi hasznosításáról, a szálláshelyek osztályba sorolásáról) a net.jogtar.hu internetes adatbázisból.

Mindezek mellett a hivatalos statisztikai adatközlésekben elérhető területi és települési adatbázisokat matematika-statisztikai módszerekkel (viszonyszám- és korreláció számítás, kereszttábla elemzések), Microsoft Excel 2007 és a SPSS Statistics 22 szoftverek felhasználásával elemeztem. 
Az elemi és számított adatok szemléletesebb bemutatására térinformatikai módszerekkel, az ArcGIS/ArcMAP 10.2 szoftver segítségével tematikus térképeket készítettem. Az kategóriahatárok beállításait és az osztályozásokat a „Natural Breaks (Jenks) féle természetes törés, továbbá kvantilisek szerinti beosztás alapján, illetve az osztályközök manuális beállításával végeztem.

Az adatok területi szintenként történő leválogatásukhoz az Országos Területfejlesztési és Területrendezési Információs Rendszer (www.teir.hu) „Interaktív elemző” alkalmazását, valamint a KSH Tájékoztatási adatbázisát (statinfo.ksh.hu) használtam.

A Központi Statisztikai Hivatal által gyüjtött turisztikai adatokkal kapcsolatban több korlátozó tényezővel és problémával szembesültem. Egyrészt a KSH nem közöl kereskedelmi és egyéb szálláshelyre vonatkozó vendégforgalmi adatot, ha az adott területi szinten háromnál kevesebb szálláshely müködik. Ez leggyakrabban települési szintű adatok esetén jelentett problémát, de a „Nem üzleti célú egyéb szálláshelyek” járási adatainál is megjelent. Témám kifejtése során gátló tényező volt, hogy a KSH nem végez adatgyüjtést a vidékturizmussal kapcsolatban, így annak teljesítménye csak közelítőleg, a meglévő adatokból számítva határozható meg.

Munkám során többször bebizonyosodott, hogy a KSH hivatalosnak tekintett adatai nem mutatnak egyezőséget, sőt bizonyos esetekben éles ellentmondásban állnak más adatbázisokkal, közte a szakmai szervezetek nyilvántartásaival. Ennek legeklatánsabb példája, hogy a KSH 2014-es adatai szerint egyes járásokban nem regisztráltak falusi szálláshelyet és vendégéjszakát, viszont a Falusi Turizmus Országos Szövetsége adatai szerint volt az adott térségben napraforgós „Nemzeti Tanúsító Védjeggyel” rendelkező szálláshely.

Értekezésem mellékletei között helyeztem el az Alföld turizmusának legföbb jellemzőit bemutató fotóadatbázist: a jellegzetes és kevésbé ismert turisztikai látnivalókról, valamint a turisztikai szolgáltatókról. A fényképek egy részét magam készítettem, a többi felvételt pedig a Magyar Turizmus ZRt.-től, valamint az alföldi Tourinform Irodák hálózatától, illetve a szakmai szereplők honlapjairól gyüjtöttem össze. 


\section{A vidék fogalma és az Alföld vidékisége}

Az utóbbi fél évszázad gyors urbanizációs folyamatai a vidéki terekben is mélyreható változásokat indítottak el. A tradícionális vidéki gazdaság és társadalom megszünt, illetve átalakult, a vidéki térségek természetközelsége, élhetősége, kulturális értékei, belső harmóniája felértékelődött. A vidéki térségek eme dinamikus átalakulása, társadalmigazdasági jelenségei Nyugat-Európában már az 1960-as évektől kezdődően kiváltották a kutatók és a döntéshozók figyelmét és érdeklődését. Elfogadottá vált, hogy az EU területének döntő többségét kitevő rurális térségek fejlesztése elengedhetetlen (CSATÁRI 2004), hiszen ott él a lakosság negyede, és a városias térségek szempontjából is kulcskérdés a vidék harmonikus fejlődése.

A következőkben a fent vázolt folyamatok nyomán a vidék fogalmának értelmezéseit, valamint a vidéktipizálási módszereket tekintem át európai és magyar kitekintésben.

\subsection{A vidék fogalmi megközelítései}

A vidék fogalmának meghatározása jó öt évtizede a regionális- és vidékkutatások egyik fő kérdésköre. Számos tudományág képviselői - agrárkutatók, szociológusok, közgazdászok, földrajzosok - foglalkoztak a témával, de egységes, mindenki által elfogadott definíció máig nem született. Abban viszont egyetértés mutatkozik a kutatók között, hogy a vidék lényegét meghatározó társadalmi, gazdasági, ökológiai folyamatokkal összhangban maga a fogalom is dinamikusan változhat (KOVÁCS-FARKAS-PERGER 2015).

A vidékről alkotott elképzelések sokfélék, s maguk a vidéktudományok (rural studies) is - interdiszciplináris tudományterületként - többek között a természeti és társadalmi földrajz, a környezettudományok, az agrártudományok, a közgazdaságtan, a szociológia, a néprajz ismereteit szintetizálják.

Nyugat-Európában a fogalom tartalma és meghatározása folyamatos fejlődésen ment keresztül az évtizedek során. Spitzer már a '80-as években végzett kutatásai során olyan önálló társadalmi-gazdasági struktúrával rendelkező téregységnek vélte, amely magában foglalja a mezö- és erdőgazdaságot, a vadászatot és halászatot, a víz- és hulladékgazdálkodást, valamint a turizmus jelentős részét (SPITZER 1991). Quendler 
„negatív” megközelítése szerint pedig minden térséget vidékinek tekintett, ami nem városi (QUENDLER 1986).

Az 1980-as években történt társadalmi-gazdasági változások hatására bekövetkező vidéki átrendeződés (rural restructuring) nyomán megjelent a szociológiai vidékértelmezés (KOVÁCH 2013). Marsden kutatásai során meghatározta a vidéki térségek ideáltípusait („megőrzött vidék”, „paternalista vidék”, „klientista vidék” és „versengő vidék”) (MARSDEN 1998). Ezt követően az 1990-es évektől az egyre bővülő agrár- és vidékfejlesztési támogatások megkövetelték egy széles körben alkalmazható definíció megalkotását, s egyre hangsúlyosabbá váltak a vidékfogalom fejlesztéspolitikai irányultságú meghatározásai. Az utóbbi évtizedekben megerősödött a vidékkutatások azon irányzata („poszt-rurális megközelítés”), amely a vidéki térségek közötti különbségek feltárására, azok elemzésére koncentrál. A korábbiakhoz képest újszerü témák kerültek a vidékkutatók érdeklődésének középpontjába, úgymint a társadalmi áramlási folyamatok, a helyi tényezők és - Ray kultúra-gazdasági elmélete nyomán - a kultúra szerepe a vidékgazdaságban.

A hazai szakirodalomban az első definiálási kísérletek a nyugat-európaihoz képest jó 3 évtizednyi késéssel, a rendszerváltás után indultak meg. Több tudományterület képviselői (agrártudományok, szociológia, földrajztudomány) tettek kísérletet a vidék fogalmának meghatározására. Élénk vita alakult ki e tekintetben Kovács Teréznek a Gazdálkodás folyóirat 1998/5. számában megjelent cikke kapcsán. Ebben az EU strukturális politikájának célkitüzéseire figyelemmel 5 mutató mentén (foglalkozási szerkezet, őstermelök száma, két népsürüségi mutató, illetve a népességszám csökkenése) tett kísérletet a vidék fogalmának megalkotására, s azokat a térségeket tekintette rurálisnak, ahol ezen feltételek közül legalább 4 teljesül (KOVÁCS 1998). Álláspontját vitatta Fehér és Dorgai, akik népsűrüségi mutatók túlsúlyára és a társadalmi jóléti, gazdaság és környezeti mutatók alul reprezentáltságára (FEHÉR 1998), illetve a Vidéki Térségek Európai kartájában megfogalmazottakhoz igazodásra hívták fel a figyelmet (DORGAI 1998).

A 2000-es évek elején - Glatz és Sarudi - munkássága nyomán hazánkban is teret nyert a vidéki térségek „,entrum-periféria” viszonyrendszerben történő értelmezése. Ebben a megközelítésben a vidék a területi, közigazgatási és funkcionális központok vonzáskörzetét jelenti (GLATZ 2005, SARUDI 2003).

Csatári geográfiai szempontú megközelítésében - mely hozzám földrajzosként a legközelebb áll - a vidék, mint speciális téregység tulajdonságaira és a benne lejátszódó folyamatokra helyezte a hangsúlyt. Értelmezésében „A vidéken tehát legáltalánosabban 
ritka települési szövetü, egy városhoz tartozó „nem városi” tér értendő. Alapvető jellemzője a mezőgazdasági táj-hasznosítás dominanciája, s falvai, szórványai részei egy város vonzáskörzetének” (CSATÁRI 2004: 332).. A vidék fogalmát a rurális terekre jellemző településhálózati sajátosságok (települések mérete, funkciói, épített környezete) irányából is igyekezett megvilágítani amikor azt írta: „Általában egyértelműen vidékies településeknek tekinthetők a szórványok (tanyák), a különböző méretü, alacsony beépítettségű és funkcióikat illetően egyre sokszínübbé váló falvak, $\mathrm{s}$ - számos tanulmány kompromisszumos mérőszáma szerint - a tíz-, illetve húszezer főnél nem népesebb települések, a kisvárosok is" (CSATÁRI 2004: 333).

A hazai kutatók közül talán legátfogóbban G. Fekete tárta fel a vidék szó jelentéstartalmának sokszínűségét, amikor így fogalmazott: „A magyar nyelvben a „vidék” egyszerre jelent tájat, tájegységet, valamilyen földrajzi szempontok szerint homogén területet, valamint falusi térséget. Sőt gyakran minden, a fövároson kívüli területet is ezzel a szóval határoznak meg" (G. FEKETE 2013: 6).

A fentiekben bemutatott hazai vidékdefiniálási kísérletek konklúziójaként kiemelhető, hogy a vidék értelmezése a gazdasági, társadalmi és ökológiai-környezeti funkciók mentén születhet meg; továbbá a vidék dinamikus fogalom, és ugyanúgy, mint a fejlett Európában hazánkban sem célszerü egyetlen rövidebb-hosszabb definícióval meghatározni azt (VIDÉKKUTATÁS 2012-2013).

\subsection{A hazai vidéki térségek tipizálása és az Alföld vidékisége}

Jóllehet a rendszerváltás után megnőtt mind a tudományos mind a politikai szféra érdeklődése a vidéki térségek iránt, a vidéki térségek tipizálására összességében mégis kevés kutató tett kísérletet.

Az első ezirányú kutatást Faluvégi végezte faktoranalízis segítségével, majd Csatári a '90-es évek közepén a vidéki térségek besorolására irányuló kutatásai során részben az OECD vidéklehatárolási módszerét vette alapul. Meghatározta a magyar kistérségek urbanitási/ruralitási indexét, és azokat a térségeket tekintette vidékinek, amelyekben az adott terület népességének kevesebb mint 50\%-a élt 120 fö/ $\mathrm{km}^{2}$-nél magasabb népsűrüségü településen. A lakosságarány alapján „,erőteljesen vidékies”, „,vidékies”, „városias” és erőteljesen városias” kategóriákat alakított ki, melyet kiegészített a magyar településszerkezeti sajátosságoknak megfelelő kategóriákkal („aprófalvas, tanyás, 
mezővárosi, kisvárosi” (KOVÁCS-FARKAS-PERGER 2015). Mindezek alapján az ezredfordulón 92 jellemzően vidéki, ezen belül 32 „erőteljesen vidéki” térség volt Magyarországon.

Értekezésem további fejezeteiben az Alföld és azon belül is a vidéki térségek turizmusával foglalkozom, így nagy jelentőséggel bír vizsgálataim szempontjából a hazai rurális terek legújabb tipizálása, melyet az MTA KRTK Alföldi Tudományos Osztályán zajlottak 2012-13-ban a Nemzeti Agrárszaktanácsadási, Képzési és Vidékfejlesztési Intézet megbízásából. A kutatási program az Európai Unió 2014-20-as költségvetési periódusára való felkészülést szolgálta, és az időközben új közigazgatási szintként megjelenő járási beosztás figyelembe vételével készült. A kutatók a munka első fázisában települési szinten vizsgálódtak. Vidékinek tekintették azokat a településeket, amelyek lakosságszáma - az ÚMVP-ben alkalmazott metódus szerint - 10.000 fő alatti és az OECD ajánlása alapján népsürüségük nem haladja meg a 150 fö/ $\mathrm{km}^{2}$ értéket. Emellett az Eurostat elhatárolásához igazodva a járások központjának népességszámát, illetve a beépített (vagy más megfogalmazásban a mesterséges felszínek) arányát is bevonták a vizsgálatba. A fentiek alapján vidékinek tekintettek minden olyan járást, amelyben 10.000 föt meg nem haladó lakosságszámú települések vannak; a központi város népessége 10.000 fő feletti, de a járás népsürüsége az országos átlag $\left(107 \mathrm{fö} / \mathrm{km}^{2}\right)$ alatti; a központi település népsürüsége 50 ezer fő fölötti, de a térség népsűrüsége szintén országos átlag alatti (VIDÉKKUTATÁS 20122013).

Ezen szempontok figyelembe vételével az ország területének túlnyomó többsége, több mint 79\%-a, összesen 136 járás (benne 2513 település) minősült vidéki térségnek, ahol a lakosság közel 45\%-a élt 2011-ben. 


\section{2. ábra: A magyarországi járások komplex típusai}

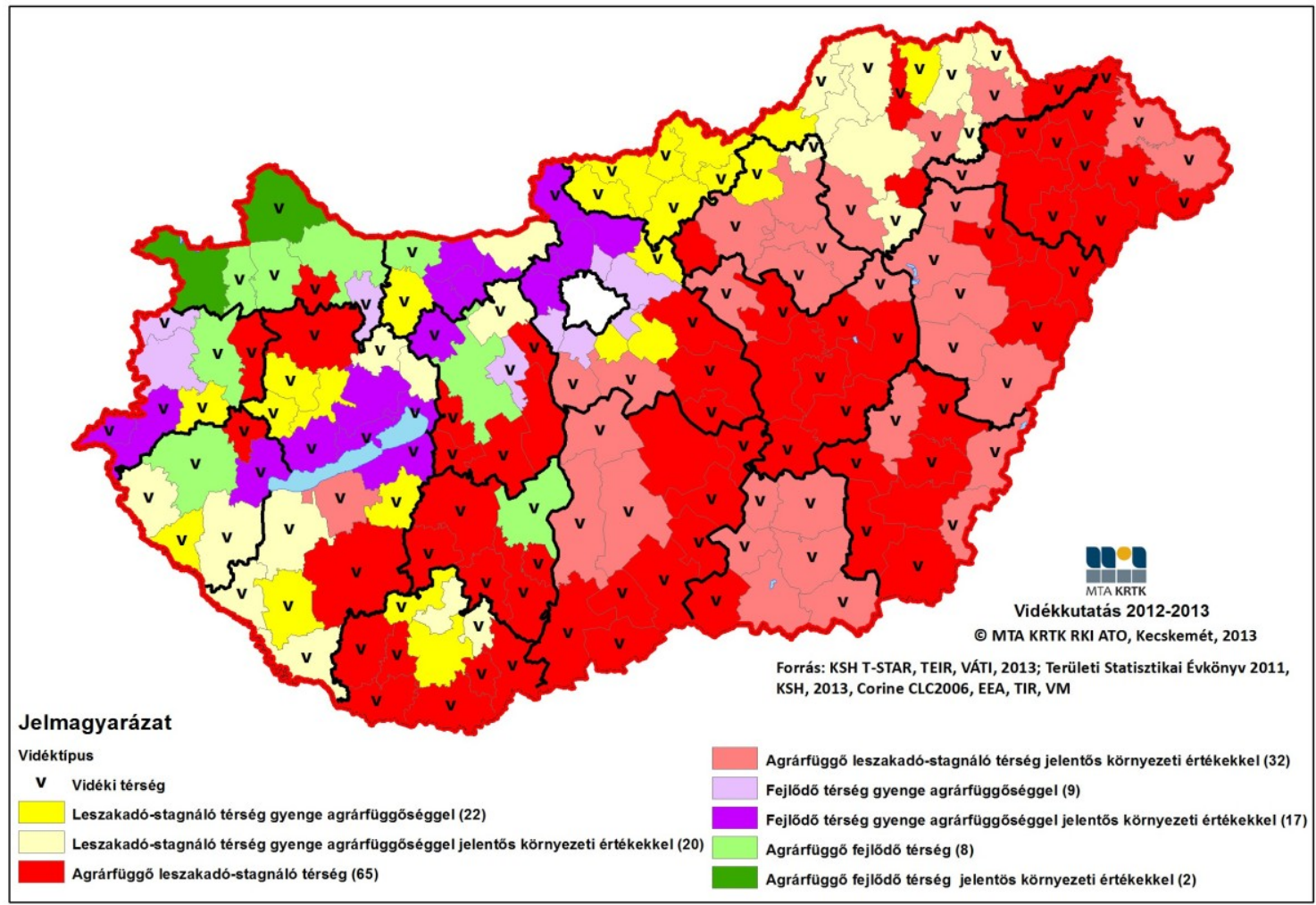

Forrás: Vidékkutatás 2012-2013.

\section{3. ábra: A vidéki járások komplex típusai}

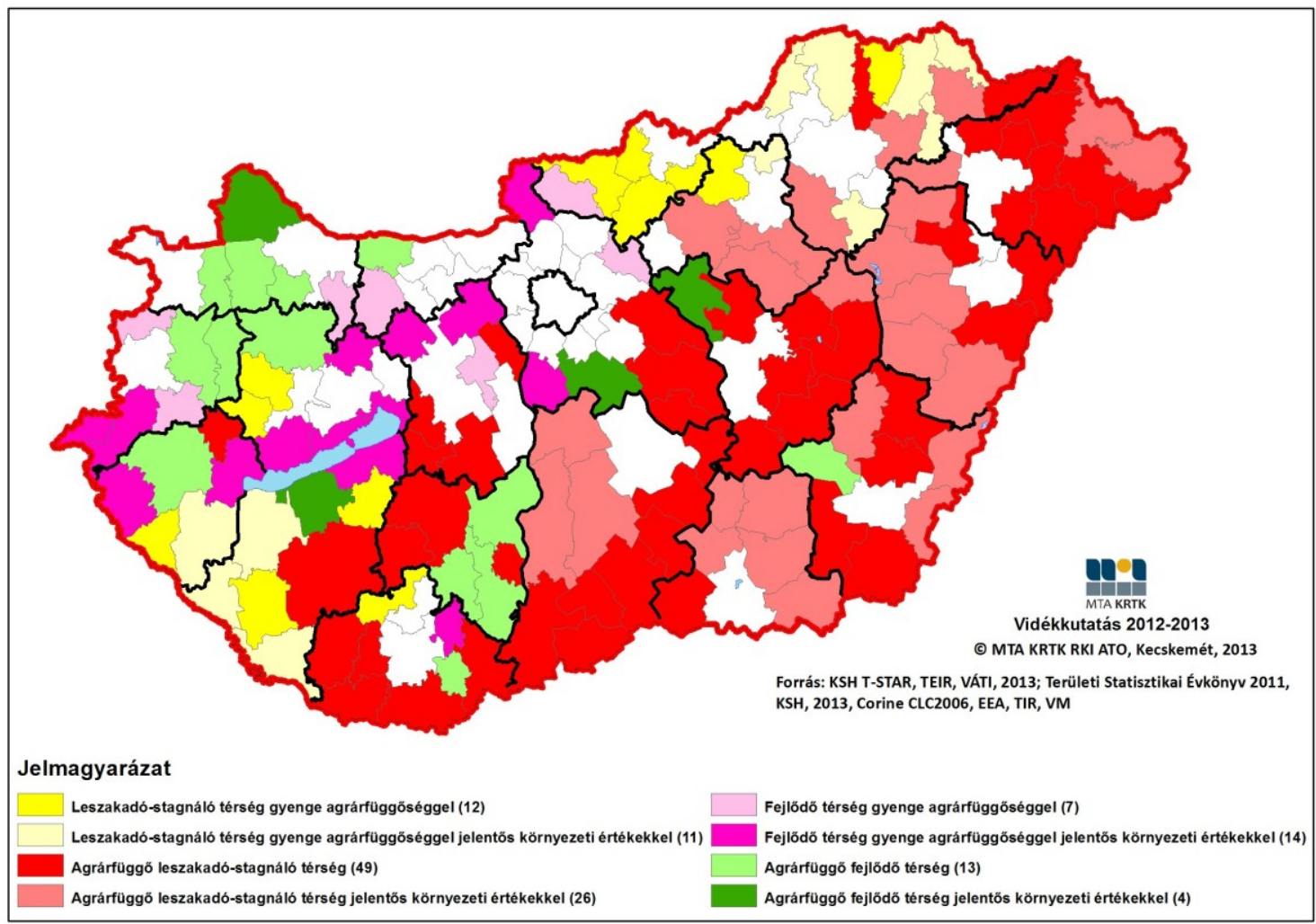

Forrás: Vidékkutatás 2012-2013. 
A kutatás eredményei szerint az Alföld általam vizsgált 70 járása közül mindössze 9 került a városias kategóriába, s ezen térségek között számos olyan is van, amelyben erőteljes valamely vidékies jelleget meghatározó tényező (pl. tanyai népesség átlag feletti aránya). Az alföldi vidéki járások komplex típusait tekintve többségük az „Agrárfüggő leszakadó-stagnáló térség” vagy az „Agrárfüggő leszakadó-stagnáló térség” típusba tartozik.

A vidékkutatási programban felhasznált mutatók (népsürüség, népesség) részletesebb, térségspecifikus áttekintésével, illetve néhány további „vidékiség faktor” mentén még eklatánsabban kirajzolódik az Alföld rurális jellege.

Kiindulópontnak tekinthetők az Alföld természeti viszonyai. Noha a régió mára jelentős mértékben emberi tevékenység által átalakított táj, mégis számos környezeti-táji értékkel bír. Az ezek megőrzésére hivatott és szigorú oltalmat biztosító három nemzeti parkhoz tartozó települések összterülete $11400 \mathrm{~km}^{2}-\mathrm{t}$ tesz ki, mely az Alföld területének több mint 25\%-a. A kapcsolódó természetvédelmi területetekkel a megőrzés mellett a fenntartható tájgazdálkodást és az értékek bemutatását is szolgálják, s a táj vidékies arculatát meghatározzák.

Az utóbbi évtizedek átalakulási folyamatai ellenére tetten érhető maradt az Alföld agrárjellege, amit egyértelműen mutat, hogy a 2010. évi Általános Mezőgazdasági Összeírás adatai szerint a régió országoshoz mért terület és népesség arányát messze meghaladják a primer szektor mutatói akár a földterületet használók, akár az állattartó és egyéni gazdaságok arányát vizsgáljuk. Noha az ágazatban foglalkoztatottak aránya jelentősen csökkent az utóbbi évtizedekben, az agrárium szerepe még ennek ismeretében is jelentős a térség gazdaságában.

1. táblázat: Az agrárium mutatói (2010)

\begin{tabular}{|l|r|r|r|r|r|}
\hline & \multicolumn{1}{|l|}{$\begin{array}{l}\text { Egyéni } \\
\text { gazdaságok } \\
\text { száma (db) }\end{array}$} & $\begin{array}{l}\text { Állattartó } \\
\text { gazdaságok } \\
\text { száma (db) }\end{array}$ & $\begin{array}{l}\text { Földterületet } \\
\text { használók } \\
\text { száma (db) }\end{array}$ & $\begin{array}{l}\text { Népesség- } \\
\text { szám (fó) }\end{array}$ & $\begin{array}{l}\text { Terület } \\
\left.\mathbf{( k m}^{\mathbf{2}}\right)\end{array}$ \\
\hline Alföld & 307.312 & 219.244 & 310.378 & 3.301 .013 & 41.973 \\
\hline Magyarország & 567.446 & 381.631 & 576.050 & 10.000 .023 & 93.027 \\
\hline Alföld/Magyarország & $54,16 \%$ & $57,45 \%$ & $53,97 \%$ & $33,01 \%$ & $45,12 \%$ \\
\hline
\end{tabular}

Forrás: TeIR, Általános Mezőgazdasági Összeírás 
Az Alföld az ország ritkán lakott tájai közé tartozik, s a vidékiség kritériumaként Európában általánosan alkalmazott népsürüség alapján is megkérdőjelezhetetlen vidékisége. Az országos átlagnak $\left(107 \mathrm{fő} / \mathrm{km}^{2}\right.$ ) 3/4-ét sem éri el az $1 \mathrm{~km}^{2}$-re jutó lakosok száma a régióban. Mindössze 10 járás esetén magasabb a népsürüség, mint az országos átlag, s ugyanennyi haladja meg a vidékiség hazai kritériumaként elfogadott $120 \mathrm{fö} / \mathrm{km}^{2}$ értéket is. E fölötti adat csak a megyeszékhelyek és néhány kis területủ járás esetén fordul elő. Magas, $200 \mathrm{fő} / \mathrm{km}^{2}$ fölötti népsürüség csak régió legnagyobb városaihoz (Debrecen, Szeged, Nyíregyháza) tartozó térségek esetén jellemző. A többi megyeszékhely járása (Békéscsaba, Kecskemét és Szolnok) e mutatót tekintve szinte átmenetet képez a rurális kategória felé.

Speciális vidéki, sőt kifejezetten alföldi jegyeket mutat az Alföld településhálózata, mely sajátos, történelme által meghatározott fejlődési utat járt be. Csak e tájon jellemző elemei, az alföldi mezővárosok és kismezővárosok jóllehet magukon viselik az utóbbi bő fél évszázad sokszor romboló hatású folyamatainak nyomait, mégis sok tekintetben megőrizték egykori arculatukat és miliőjüket. Egészen speciális alföldi településformának számít a tanyarendszer, melynek mennyiségi sorvadása az utóbbi másfél évtizedben megállt, sőt az utóbbi két népszámlálás között némileg még nőtt is a külterületen élök száma. Funkcionálisan azonban átalakulóban van a tanyarendszer. Erősödik a lakófunkció azáltal, hogy jelentős számú a városokból megélhetési gondok miatt kiköltözők száma, illetve a nagyvárosok körül megjelentek a szuburbán tanyák. A legutóbbi népszámlálás adatai szerint hazánkban külterületeken él a népesség 3,1\%-a (NÉPSZÁMLÁLÁS 2016.) Egyértelműen az Alföldön jellemző a tanya mint településforma, hiszen a hazai külterületi lakosság 2/3-a e tájon él, azon belül is legnagyobb számban a Duna-Tisza-közén.

Az Alföld természeti-táji adottságai, népességi és települési viszonyai alapján összességében vidéki területnek tekinthető, melyből néhány, elsősorban a legnagyobb városokhoz köthető urbanizáltabb térség emelkedik ki. A városok és a „vidékek” társadalmi és gazdasági tekintetben oly szorosan összeforrtak a történelem során, hogy e vidékies térség jövőbeli fejlesztése is - ahogyan hosszú évszázadokon keresztül - csak a városok fejlődésével összhangban lehet sikeres (CSATÁRI 2001.) 


\section{A turizmus és a vidékturizmus földrajzi értelmezése}

\subsection{A turizmusföldrajz és a vidékföldrajz kapcsolata}

A vidék fogalmának értelmező bemutatása után a turizmus általános fogalmi megközelítéseiből kiindulva a vidéki területek turizmusának földrajzi értelmezését kísérlem meg. Mindenekelött azonban szükségszerü röviden kitérni a turizmus alapfogalmára, a turizmus- és a vidékföldrajz összefüggéseire, kapcsolódási pontjainak ismertetésére.

A XX. században lejátszódó társadalmi-gazdasági folyamatok a turizmusban is mélyreható változásokat idéztek elő. A II. világháború után a szabadidő és a diszkrecionális jövedelmek növekedésével a turizmus tömegjelenséggé vált. A turizmus fogalma a jelenség mind szélesebb körben való elterjedésével párhuzamosan módosult. Az I. világháború után elsőként a „berlini iskola” kutatói, Glüncksmann és Schwink foglalkoztak definíciójának megalkotásával ${ }^{1}$, majd később Hunziker és Krapf svájci professzorok határozták meg az évtizedeken át elfogadott - csak az ,idegen”forgalomra koncentráló, mára már meghaladott - fogalmát ${ }^{2}$.

Burkart és Medlik 1981-ben megjelent könyvében a turizmus koncepcionális és technikai meghatározásának elkülönítését javasolta. Míg az előbbi széles körű elméleti keretét adja a jelenségnek és meghatározza alapvető jellemzőit, addig az utóbbi időről-időre módosulhat statisztikai, jogalkotási és operatív okokból egyaránt. A szerzőpáros öt fö jellemző mentén jelölte ki a turizmus fogalmi kereteit:

- A turizmus az emberek mozgásából és az adott desztinációban való tartózkodásából eredeztethető.

- Két eleme van minden turisztikai tevékenységnek: az utazás a célterületre és az ott tartózkodás, mely magában foglal számos tevékenységet.

- Az utazás a szokásos tartózkodási helyen és munkahelyen kívülre történik.

- A turisztikai célterületekre való mozgás csak ideiglenes, időben rövid távú, és néhány nap, hét, hónap múlva a turisták visszatérnek.

\footnotetext{
${ }^{1}$ „Az idegenforgalom a meglátogatott helyen a csak átmenetileg tartózkodó emberek és a helység lakosai közötti kapcsolatok összessége.” (GLÜNCKSMANN 1935)

${ }^{2}$, Az idegenforgalom azon kapcsolatok és jelenségek összessége, amely a meglátogatott hely szempontjából idegenek utazásából és tartózkodásából áll, amennyiben a tartózkodás letelepedéshez és ezzel járó jövedelemszerzési tevékenységhez nem kötődik.” (HUNZIKER ÉS KRAPF 1942)
} 
- A turisztikai célterületek meglátogatása elkülönül az állandó lakóhelyen, munkahelyen belüli mozgásoktól (BURKART - MEDLIK 1981).

Ezt követően alkotta meg Lengyel Márton a turizmus korábbiakhoz képest újszerü definícióját, amely rövidített formában a WTO és az Interparlamentáris Unió által elfogadott Hágai Nyilatkozatba is bekerült. Eszerint: „A turizmus magában foglalja a személyek lakó- és munkahelyén kívüli minden szabad helyváltoztatást, valamint az azokból eredő szükségletek kielégítésére létrehozott szolgáltatásokat" (LENGYEL 1992: 37). Lengyel megközelítése a korábbiakhoz képest változást hozott több tekintetben is. Egyrészt szélesebben értelmezte a turizmus dimenzióit és rámutatott arra, hogy a turizmus az emberek életének meghatározó részét képezi. Másrészt tágabban értelmezte a turisztikai kínálat fogalmát, abba beletartozónak vélte a turisták és a helyi lakosság által is használt létesítményeket. Harmadrészt a jelenség gazdasági aspektusai mellett előtérbe helyezte annak társadalmi, kulturális, környezeti és életminőségi vonatkozásait (LENGYEL 1992).

Vizsgálataim során a turizmust a geográfia szemszögéböl elemzem, ezért kulcsfontosságú volt számomra Leiper átfogó, holisztikus turizmus-definíciója, melyben megjelenik az ágazat sokrétű földrajzi kapcsolatrendszere: „A turizmus egy öt elemből álló és a szélesebb környezettel kölcsönhatásban lévő nyílt rendszer, amelynek elemei a következők: a turisták adják a dinamikus emberi elemet; a kibocsátó terület, a tranzitút és a fogadó terület adják a három földrajzi elemet; végül a turizmus szektor a gazdaságit. Mind az öt elem funkcionálisan és térbelileg rendezett kölcsönkapcsolatban van a fizikai, technológiai, társadalmi, kulturális és politikai tényezőkkel. A dinamikus elemet az utazó személyek képezik, akiknek az utazása bizonyos mértékig a szabadidőn alapul, és legalább egy éjszakás tartózkodással jár." (LENGYEL 1992: 31). Mindezek alapján könnyen felfedezhető a kapcsolat a definícióban felsorolt tényezők és a földrajzi környezetet alkotó természeti környezet (ökoszféra), az átalakított környezet (technoszféra), a társadalmi gazdasági környezet (termelő szféra) és a politikai kulturális környezet (szolgáltató szféra) között (SZABÓ 2006). 


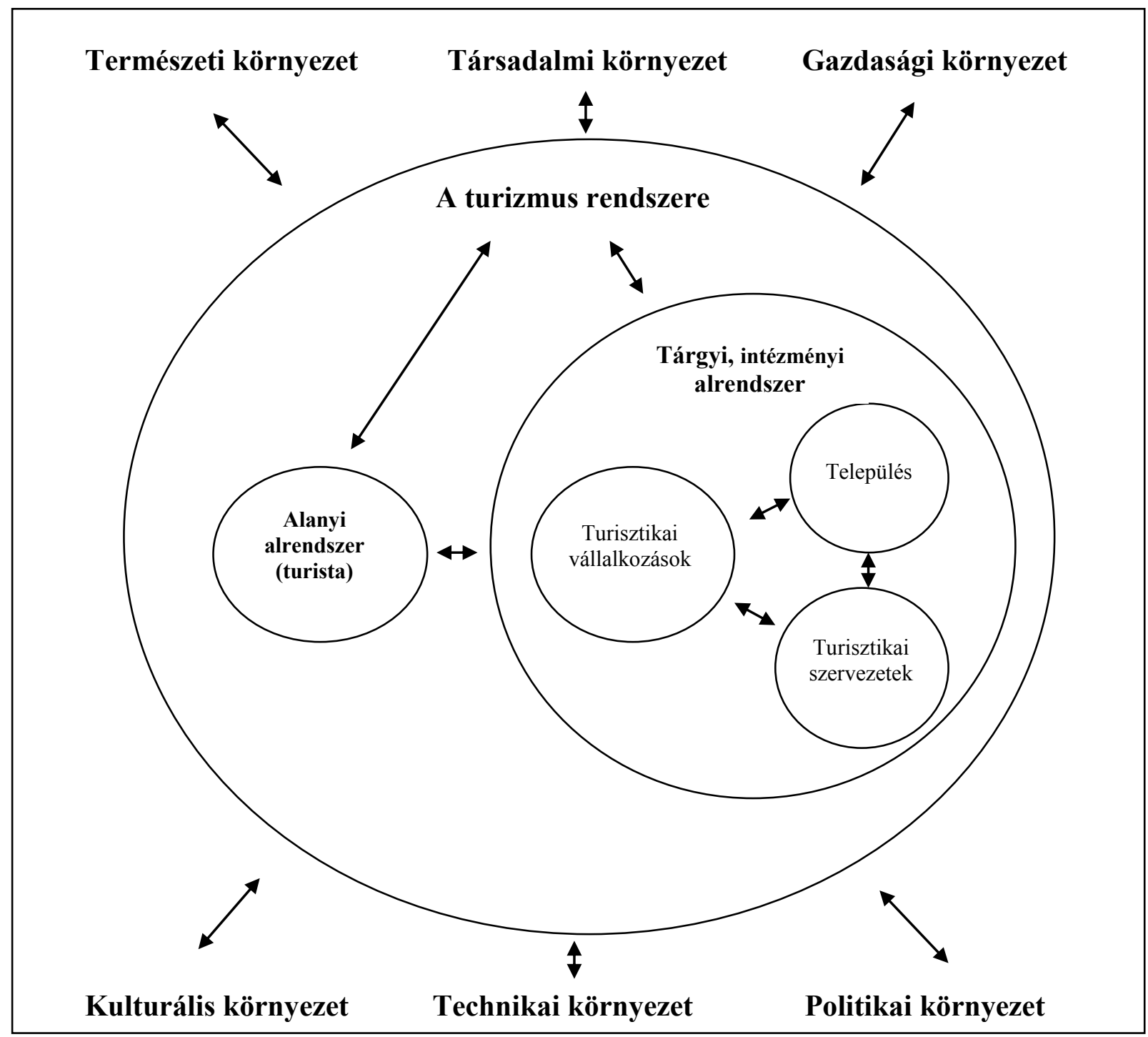

Forrás: Kaspar és Pompl alapján saját szerkesztés

A Hágai Nyilatkozat (1989) kiadása óta eltelt több mint 25 év, a globalizáció felgyorsulása a turizmus tartalmának változásához vezettek, így a fogalom újragondolása is szükségesség vált. A lakó- és munkahely „határvonala” mára a világ fejlett részein egyáltalán nem olyan éles mint korábban, a migrációs folyamatok új, részben turisztikai értelmezése alapján pedig a szabad helyváltoztatás definíciós kritériuma kérdőjelezhető meg (MICHALKÓ 2008). Mindezekre figyelemmel Michalkó Gábor a turizmus új, földrajzi szempontokat figyelembe vevő definícióját alkotta meg, mely szerint: „A turizmus az egyén élményszerzéssel párosuló környezetváltozása, amelynek során szolgáltatások igénybevételére kerül sor.” (MICHALKÓ 2008: 18) Meghatározása középpontjába két - a korábbiakhoz képest új - kulcstényezőt helyezett. Egyrészt az élményszerzést, mely az 
ember legfőbb célja a turisztikai tevékenység révén, másrészt a környezetváltozást, mely akkor tekinthető turizmusnak, ha mindennapi térpályáit elhagyja az ember.

Mindezen elméleti jellegü fogalom meghatározások mellett a turizmus jelenségének praktikumhoz igazodó leírásai általában három fő szempont mentén történnek:

- Az utazás célja (pl. az utazó típusa, üzleti utazás, nyaralás, barátok, rokonok meglátogatása, egyéb okok).

- Az utazás időtartama: minimum 24 órát, maximum 1 évet töltsön az utazó lakóhelyétől távol.

- Azon helyzetek tisztázása, amikor az utazó turistának számít vagy nem: pl. hajós utazók, kevesebb mint 24 órát a célterületen tartózkodók (HALL - PAGE 2006).

A turizmussal kapcsolatban több kutató is hangsúlyozza a fogalom interdiszciplináris jellegét, és kiemeli annak a földrajzzal való szoros kapcsolatát, valamint földrajztudomány megkülönböztetett jelentőségét a turizmus folyamatainak elemzése és értelmezése tekintetében (LENGYEL 1992, SZABÓ 2006. MICHALKÓ 2007). A turizmus erőteljes földrajzi dimenzióit külön kihangsúlyozza Michalkó. Megfogalmazása szerint a turizmusföldrajzi vizsgálatok során ,az egyén átmeneti térbeli mobilitására épülő, az eltérő környezeti feltételeket kínáló helyek közötti mozgásjelenségekre és magára a helyre koncentrálnak, vagyis a vizsgálatuk tárgya a földrajz központi kérdése, a tér" (MICHALKÓ 2007: 18). S maga a földrajzi tér is erőforrás a maga sajátos, egyedi meg nem ismételhető tulajdonságaival.

A fogalmi megközelítések változásával párhuzamosan a turizmuskutatás földrajzi irányzatai átalakultak. Nemzetközi szinten már a XX. század elején megjelent a turizmus kutatása. Christaller határozta meg elsőként turizmusföldrajz helyét a földrajztudományon belül, a gazdaságföldrajzi ágazatok közé sorolva azt (AUBERT 2006). A német geográfiában később a szociálgeográfiai irányzat berkein belül jelent meg a turizmus. Az 1960-as évektől egyre több olyan turisztikai tárgyú kutatás látott napvilágot, amely e részdiszciplína egyik társadalmi alapfunkciójához, a szabadidő eltöltéséhez kapcsolódóan tárgyalt turisztikai kérdéseket. A XX. század utolsó évtizedeiben a tömegturizmus általánossá válásával előtérbe kerültek az ágazat fenntarthatósági kérdései és környezeti hatásai (AUBERT 2006). Hazánkban az első turizmust érintő vizsgálatok a külföldiekhez képest időbeli késéssel jelentek meg, és főleg természeti földrajzi irányultságúak voltak (környezetminősítések, tájértékelések). Ezt követően Magyarországon is megerősödtek a szociálgeográfiai, a turizmusban résztvevő társadalmi csoportok tevékenységeit, valamint a 
turizmus településekre gyakorolt hatásait vizsgáló kutatások. Ugyancsak jellemzőek voltak hazánkban is az idegenforgalmi földrajzi témájú elemzések, melyek a gazdaság egyik alágazataként, a szolgáltató szektoron belül értelmezték a turizmust (SZABÓ 2006).

A turizmusföldrajzi vizsgálatok és elemzések során a kutatók egyaránt használják és szintetizálják a földrajztudomány más részterületei, így a geomorfológia, a geológia, a hidrológia, a népesség- és településföldrajz, a mezőgazdaság földrajza, a szolgáltatások földrajza és még számos részdiszciplína eredményeit. Sőt turizmusföldrajz nem csak a földrajztudomány ismereteire épít, hanem multidiszciplináris jellegénél fogva a földtudományi, földrajzi és a földrajzon kívüli tudományterületek, összesen mintegy 20 tudományterület eredményeit is szintetizálja. A közgazdaságtan, a demográfia, szociológia, a néprajz, az orvostudományok felé meglévő kapcsolatok erőteljesek, egyértelműek és viszonylag hosszabb időre tekintenek vissza, míg a politikai tudományok, a nyelvtudományok, a jogtudományok és a pedagógia újabb keletűek. Mindezek együttesen segítik a turizmusföldrajzi ismeretek és tudás létrejöttét (MICHALKÓ 2007).

Mint a korábban utaltam rá, a vidékkutatások és a vidékföldrajz igen jelentős átalakuláson ment keresztül az elmúlt fél évszázadban. Több mint egy évszázada az erőteljes iparosodás és az urbanizáció megváltoztatta a vidéki társadalmat. A mezőgazdasági jövedelmek csökkenő reálértékéhez és technológiai változásokhoz csatlakozott a mezőgazdasági foglalkoztatás csökkenése is. Válaszul a vidéki szolgáltatások (üzletek, iskolák, egyházak, szolgáltatások és a közlekedés) is átalakultak (LANE 1994). Az 1990-es években egyre inkább a vidéki területek átalakulása, az ezzel együtt járó társadalmi, gazdasági és környezeti kérdések kerültek a kutatások elöterébe. Napjainkban, pedig a posztmodern fejlődési szakaszban a vidék mint fogalom új, komplex értelmet nyer, „ahol a vidék társadalmi, morális és kulturális értékeket takar” (FARKAS 2010). A turizmus pedig a vidéki térségekben éppen és legfőképpen ezen értékeken alapuló erőforrásokat hasznosítja. Nem véletlen tehát, hogy a vidékföldrajz a társtudományok közül a turizmusföldrajzzal áll az egyik legszorosabb kapcsolatban (HALL - PAGE 2006), s a vidékföldrajzi kutatások fókuszpontjába újabb és újabb kutatási témák és célterületek kerültek, köztük egyre hangsúlyosabbá vált a turizmus is. 


\subsection{A rurális turizmus értelmezése, nemzetközi megközelítései}

A fogalom meghatározására Európában nincs egységes definíció, sőt még a jelenség elnevezésére is sokféle változatot találhatunk a szakirodalomban. A rural-, agri-, agro-, farm-, zöld-, szelíd és lágy turizmus elnevezés sokszor szinonímaként egyaránt felbukkan a vidéki környezetben, a helyi erőforrásokra alapozott turizmus kapcsán (KOVÁCS 2003, MIKLAY F.-NÉ 2007). Emellett a rurális turizmus keretében nyújtott szolgáltatások és az elnevezés is országonként különböző. Míg német nyelvterületen az „Urlaub am Bauernhof” („Üdülés parasztudvaron”) elnevezéssel illetett tevékenység keretében paraszti gazdaságokban fogadják és látják el a turistákat, addig Nagy-Britanniában a „Holiday in farm” fedi le ezt a szolgáltatáscsomagot. Franciaországban elzászi területein a „FermesAuberges” fogadó farmot, míg a „Gites-Ruraux” falusi szállást jelent, de Lotharingiában a „Gites de France” elnevezés terjedt el. Olaszországban kettéválik az agroturizmus és a rurális turizmus, s az agroturizmust csak agrárgazdálkodók végezhetik. Spanyolországban területi megkülönböztetéssel élnek, s csak az ország belső, nem tengerparti területeire irányuló turizmust tekintik rurális turizmusnak.

A rurális turizmus legátfogóbb kutatói meghatározását Jansen-Verbeke fogalmazta meg 1990-ben. Értelmezése szerint ebbe a fogalomkörbe tartozónak vélt minden olyan turizmusformát, amely „vidéken található” (JANSEN-VERBEKE 1990). Az agriturizmushoz pedig inkább a mezőgazdasághoz és annak termékeihez kapcsolódó turisztikai kínálatot sorolta. A farm turizmus kifejezés alatt a farmmal közvetlen kapcsolatos turisztikai formákat értette: az ott történő elszállásolást, az étkezést és szórakozást, illetve az oda történő kirándulást (JANSEN-VERBEKE 1990).

A kutatói értelmezéseken túl természetesen fejlesztői-fejlesztéspolitikai célzatú értelmezések is szép számmal születtek. A '80-as évektől kezdődően az agrártermékek piacán megjelenő túltermelés, majd a mediterrán államok csatlakozása egyre inkább ráirányította az Európai Unió szerveinek (Európa Tanács, Európai Bizottság) figyelmét is az elmaradott, vidéki területek felzárkóztatására és a vidékgazdaság diverzifikációjának szükségességére, amelynek fontos eszközeként jelölték meg a rurális turizmust. Az Európa Tanács a '80-as évek végén külön tanulmányt szentelt a témának, melyben magát a fogalmat csak körülírták, de nem határozták meg. Fontos azonban kiemelni, hogy a tanulmány kihangsúlyozta a helyi szereplők összefogásának szükségességét a rurális turizmus sikere érdekében (KOVÁCS 2000.) 
Az Európai Bizottság ettől kezdve jóval pragmatikusabban kezelte a rurális turizmus témakörét. A fejlesztéspolitikai célokhoz illeszkedően, azok megalapozására adták ki a 4/86-os Bulletint, amely szerint - Jansen-Verbeke definíciójához hasonlóan - minden vidéki környezetben zajló turisztikai tevékenység részét képezi a fogalomnak. Az 1988-ban megjelent, és a vidéki térségek fejlesztésének alapkövének tartott, „A vidéki társadalom jövője” („The future of Rural Society”) dokumentum hasonlóan, de a gyakorlathoz közelebb álló módon a farmon történö üdülés mellett más, vidéki területeken folytatott turisztikai tevékenységeket is a fogalom részének tekint (EUROPEAN COMMISSION 1988).

A legfejlettebb ipari országokat tömörítő OECD szintén közzétett a témában egy dokumentumot, mely sok ponton hasonlóságot mutat a Bernard Lane által jegyzett, a rurális turizmus egyik legkonkrétabb, részletekbe menően kidolgozott és hozzám közel álló értelmezést adó „What is rural tourism?” című tanulmányával, melyet az alábbiakban részletesebben ismertetek.

Tanulmányában Lane rávilágít arra, hogy a turizmus régebben, és még nagyrészt korunkban is erősen a fürdőhelyekhez, tavakhoz, hegyvidéki üdülöhelyekhez és a legfontosabb kulturális centrumokhoz kötődik. Több kutató eredményeire (Plog, Weiler és Lane) hivatkozva feltárja, hogy az utóbbi években az egyéni utazók számának emelkedése nyomán a vidéki területekre irányuló turizmus új lehetőségeket nyit ezen térségek számára gazdaságuk megújulására, átstrukturálódására.

Lane a rurális turizmus részeként értelmezte azon turisztikai termékeket, amelyek vidéken realizálódnak, de egyúttal jelezte, hogy nehéz olyan általános érvényü definíciót megadni, amely valamennyi ország vidéki területeire érvényes.

A fogalom pontos meghatározása kapcsán több problémát jelzett:

- A városi vagy üdülőhelyi turizmus nem korlátozódik a városi területekre, hanem vidéki területeken is megjelenik.

- A vidéki térségeket önmagukban nehéz meghatározni, és a kritériumok, amelyeket a különböző országok alkalmaznak jelentősen eltérnek.

- Nem minden turisztikai tevékenység sorolható be egyértelmúen a "vidéki" vagy a „városi” kategóriába. Vidékiségük mértékének megítélése egyaránt lehet érzelmi és technikai kérdés.

- Történelmileg a turizmus városi jelenség. A turisták nagy többsége városi területeken él. A turizmus akár az urbanizáció hatása is lehet a vidéki területekre. 
- A rurális turizmus különböző formái eltérően fejlődtek a különböző országokban. A farm alapú üdülés igen elterjedt Németország és Ausztria számos részén, sokkal ritkábbak a vidéki USA-ban és Kanadában.

- A vidéki térségek maguk is összetett változási folyamat részesei. A város és vidék közötti egykor világos különbséget elmossa a szuburbanizáció, távolsági ingázás és második otthonok fejlődése.

- A rurális turizmus komplex, sokrétü tevékenység, nem csak mezőgazdasági alapú turizmus. Magában foglalja nem csak a farmon történő nyaralásokat, hanem a tematikus természeti környezetben megvalósuló üdülést, de az ökoturizmust, a gyaloglást, a hegymászást és lovas kirándulást, a kaland-, sport és egészség turizmust, a vadászatot, a horgászatot, tanulmányi célú utazásokat, a művészeti és örökségturizmust, és egyes területeken az etnikai turizmust is (LANE 1994).

A definíció tartalmával kapcsolatosan fontos megállapításokat tesz Lane. Egyrészt meglátása szerint a rurális turizmus nem mentes a „városias” befolyásoltság alól, másrészt hangsúlyozza, hogy a vidéki terek rendkívüli változatossága azok turizmusában is tükröződik, harmadrészt a rurális turisztikai termékek egyedisége magában a terület vidékiségében rejlik (LANE 1994). Ezek felismerése és világossá tétele - úgy vélem nagyon lényeges a fogalom pontos tartalmának meghatározása szempontjából.

Lane a fogalmat nem egy rövid definíció leszükített lehetőségei között értelmezi, hanem - a város-vidék kontinuum elméletet bevonva - egy speciális koncepciót vázol fel. Ebben a vidékiség fogalmát az alacsony népsürüségü nyitott terekkel és a kis léptékü, általában 10 ezer lakos alatti településekkel kapcsolja össze, ahol a földhasználat uralják a mezö-, erdőgazdálkodási tevékenységek, valamint a természetes állapotában megörzött területek (LANE 1994.)

Mint korábban utaltam rá az OECD rurális turizmus értelmezése sok tekintetben azonos vonásokat mutat Lane koncepciójával. Maga a szerző is hivatkozik az OECD vidékkel és turizmussal kapcsolatos tanulmányára, amikor arról ír, hogy az OECD a vidéki térségeket periférikus vagy távoli régiókra, "köztes" régiókra és gazdaságilag integrált vidékfejlesztési régiókra osztja. A peremterületeket gyér lakosság, kisüzemi gyakran a hagyományos vállalatok, nagy kezelési költség és viszonylagos gazdasági elmaradottság jellemzi. A másik végletet jelentő fejlett régiók gazdasága diverzifikált, az ott igénybe vehető szolgáltatások széles skálán mozognak. A köztes területek két véglet között helyezkednek el. A három típus nem különül el élesen egymástól, széles átmeneti zónákkal kapcsolódnak egymáshoz. Lane ezen logikai összefüggéseket alkalmazza a vidéki területek 
turizmusának tipizálása kapcsán is. Kiemeli, hogy az OECD tipológiájának jelentős következményei vannak mind a vidékfejlesztésre, mind a rurális turizmusra. A települések mozoghatnak a „kontinuum” mentén. A változás, a települések és térségek elmozdulása jellemzően, de nem mindig - a városi pólus felé történik. Mint Lane írja, a rurális turizmus "legtisztább" formában vidéki térségekben található, ahol általában 10.000 fö alatti települések jellemzőek. Ezeken a területeken még megőrződött a természeti környezet és a kulturális örökség, turizmusuk kis léptékü; alacsony intenzitású és szervesen kapcsolódik a helyi közösség életéhez (LANE 1994).

A rurális turizmushoz tartozó turisztikai termékekkel kapcsolatban Lane megjegyzi, hogy meghatározásuk nem könnyü feladat, és nem adható meg kizárólag alapvető jellemzőik szerint, hiszen a használat intenzitása, az integráció a közösséggel és más tényezők mind közrejátszanak tartalmuk kialakításában. Felhívja a figyelmet, hogy a városi és vidéki térségekben is előfordulhatnak azonos vagy hasonló turisztikai termékek. Azok rendszerezése a kontinuumelmélet logikájához igazodik: a vidék-specifikustól a városspecifikus üdülések irányába haladva sorolja be az egyes turisztikai termékeket, és megjelöl egy széles köztes kategóriát is (LANE 1994).

\section{2. táblázat: A turisztikai termékek besorolása Lane szerint}

\begin{tabular}{|l|l|l|}
\hline \multicolumn{1}{|c|}{ Vidékies } & \multicolumn{1}{|c|}{ Köztes (átmeneti) } & \multicolumn{1}{c|}{ Városias } \\
\hline Gyalogtúra & Úszás & Városnézés \\
Hegymászás & Alacsony / közepes intenzitású & Vásárlás/shopping \\
Kalandtúra & strandolás & Intenzív tengerparti nyaralás \\
Kenuzás & A közepes intenzitású síelés & Intenzív síelés \\
Rafting & Sport természetben, pl. golf & Városi kulturális turizmus \\
Hótalpas túra & Gasztronómiai turizmus & Állatkertek \\
Kis intenzitású síelés & Általános örökség turizmus & Intenzív egészségturizmus \\
A természet tanulmányozása & Kulturális fesztiválok & Ipari turizmus \\
Vadászat & Hajóutak & A nagyobb konferenciák \\
Kerékpártúra & Campingezés & Szórakoztató \\
Lovaglás & Városnézés & nyaralás/szerencsejáték \\
Vidéki örökség turizmus & Közepes méretü konferenciák & Üdülőhelyi nyaralás \\
Falusi turizmus & Vitorlázás & Intenzív sport, nemzetközi \\
Relaxációs üdülés & sportrendezvények \\
környezetben & Tengeri halászat & \\
Kis léptékủ konferenciák & & \\
A vidéki fesztiválok & & \\
Halászat, horgászat & & \\
Sportolás a természetben & & \\
& & \\
\hline
\end{tabular}

Forrás: LANE, B. (1994): „What is the rural tourism?” c. tanulmánya alapján saját szerkesztés 


\subsection{Az Integrált Rurális Turizmus koncepciójáról}

A vidéki területek turizmusának értelmezésére az eddigiekben felvázoltaktól eltérő megközelítésére is találhatunk nyugat-európai példát, közte a fejlesztésközpontú Integrált Rurális Turizmus (Integrated Rural Tourism $=$ IRT) modellt, mely Saxena és Ilbery munkája nyomán látott napvilágot a 2000-es évek közepén. Elméletük kiindulópontja, hogy a vidéki térségek gazdaságában fontos szerepe van a turizmusnak, s meglátásuk szerint a holisztikus turizmus felfogást tükröző IRT a fejlesztés fontos eszköze lehet az elmaradott vidéki terülteken. Megfogalmazásuk szerint az IRT „olyan turizmus, amelyet elsősorban társadalmi hálózatok tartanak fenn” (SAXENA - ILBERY 2008). A modellben a helyi szereplők helyi hálózatokká kapcsolódnak össze a lokális (belső) sajátosságok (természeti, társadalmi, kulturális, gazdasági és emberi erőforrások) mentén, azok fejlesztése és fenntartása érdekében, s a hálózatosodás révén együtt sokkal sikeresebbek lehetnek. A hálózatok lehetővé teszik a benne szereplők számára, hogy feltárják és megosszák saját erőforrásaikat, kölcsönös előnyökkel járó, hosszú távú együttmüködésekben vegyenek részt, kialakítsák és fejlesszék a közös jövőképüket, és mobilizálják erőforrásaikat (SAXENA - ILBERY 2008). Tagja lehet minden olyan szereplő, akinek turizmussal kapcsolatos céljai vannak. Egyes aktorok, pl. szállásadók jobban, mások kevésbé integrálódnak a rendszerbe. A szerzők kiemelik, hogy a hálózatok mindig az adott helyen beágyazottak, de ennek mértéke területenként különböző lehet. Megjegyzik, hogy a turisztikai hálózatok esetén mindenképpen szükséges bizonyos fokú beágyazatlanság (SAXENA - ILBERY 2008). A két fogalom közötti ellentét csak látszólagos, hiszen egymással dinamikus kapcsolatban állnak. A helyi termékek piacra jutásához, bizonyos fontos eszközök és technológiák megszerzéséhez, valamint a desztináció versenyképességének növeléséhez szükséges a beágyazottság hiánya, és a fejlödéshez szükségesek külső elemek is. Ugyanakkor a túlzott külső befolyás is káros, hiszen negatív hatása van a közösségekre, a bizalomra, megtöri a helyi szereplök erejét.

Koncepciójuk kapcsán a szerzők hangsúlyozzák, hogy a vidékfejlesztési gyakorlatban a valóság a fentebb vázoltaknál bonyolultabb. A hálózatok sokszínüsége és ellentmondásos dinamikája lehetőségeket és veszélyeket egyaránt magában rejt az IRT alkalmazása kapcsán (SAXENA - ILBERY 2008).

A hazai turizmusfejlesztési stratégiákban mindeddig nem vagy csak nyomokban volt felfedezhető az Integrált Rurális Turizmus modellje. A 2005-2013. közötti időszakra 
készült Nemzeti Turizmusfejlesztési Stratégia eleve más aspektusból, nem földrajzi, hanem sokkal inkább közgazdaságtani szempontok mentén közelítette meg a témát. Leginkább a legnagyobb vendégforgalmat generáló turisztikai termékekre és térségekre koncentrált. Az Alföld tekintetében ezek közé legfeljebb a nagy fürdőhelyek sorolhatók. A többi, kevésbé intenzív turizmussal rendelkező térség mintha mostohagyereknek számított volna. Ettől csak némileg voltak helyspecifikusabbak az ugyanezen időszakra vonatkozó, minden régióra érvényesnek gondolt tematika alapján elkészített regionális turisztikai stratégiák. A fejlesztési források elosztása azonban sokkal inkább a tervezési-statisztikai régiók alapdokumentumai alapján történt. A program alapelveiből következően más megközelítés érvényesült a strukturális alapokhoz képest nagyságrendekkel kisebb forrásokkal rendelkező LEADER térségek fejlesztési dokumentumaiban. Sokkal inkább tükröződtek bennük a helyi sajátosságok vagy akár a fenti modellek bizonyos elemei. A jövőben pedig megkerülhetetlen az Alföld és más hasonlóan vidékies térségek esetén a fentiekben ismertetett megközelítések - akár csak részleges - adaptációja, s ezáltal az eddig tapasztaltaknál sokkal adekvátabb, a „hely szelleméhez” jobban igazodó és reálisan megvalósítható turisztikai fejlesztési terveket lehetne kialakítani.

\subsection{A rurális turizmus fogalmának hazai megközelítései}

A jelenség elnevezésére Magyarországon „falusi turizmus” elnevezés honosodott meg és terjedt el, ami a német „Urlaub am Bauernhof” fordításának felel meg. A Jenkei által összeállított Idegenforgalmi értelmező kéziszótár jó kiindulópontot jelent a falusi turizmus fogalmának bemutatásához. Eszerint beletartozik „a városon kívüli, helyi és regionális vonzóerőkkel rendelkező, gondozott falusi, vidéki környezetben, a belföldi és külföldi vendégek szabadidő-eltöltési szükségleteinek széles körü, kereskedelmi alapokon történő kielégítése és az ezt szervező helyi intézmények és szolgáltatók együttműködése" (JENKEI 2002). Ez a meghatározás úgy gondolom korrekt összegzését adja a jelenségnek, azonban más jellegü és tartalmú definíciók is születtek az elmúlt jó 20 év során.

A hazai falusi turizmusban érdekelt szálláshelyeket és szolgáltatókat tömörítő Falusi és Agroturizmus Országos Szövetsége (FATOSZ) müködése több mint 20 éve alatt folyamatosan foglalkozott a fogalom meghatározásával. Az első ilyen kísérletek közé tartozott Csizmadia értelmezése, melyben a falusi turizmust falun élő lakosság jövedelemkiegészítő tevékenységéként jelölte meg, melynek során lakóházaik 
kihasználatlan szálláshelyeit adják ki üdülési céllal (CSIZMADIA 1993). Ez a meghatározás mai szemmel nézve meglehetősen szük keretek között és csak a falusi szállásadásra fókuszálva értelmezte a vidéki környezetben zajló turizmust. Ezt maga a szerző is jelezte, $\mathrm{s}$ a fogalom tágabb definiálása során a szállásadáson túl a vidéken elérhető kapcsolódó szolgáltatásokat is ide sorolta. A későbbiekben, a FATOSZ által közétett, elméleti alapvetéseket tartalmazó tanulmányokban már „vidéki (falusi)” turizmusnak ${ }^{3}$ nevezték a jelenséget (CSIZMADIA 2013, MIKLAY F.-NÉ 2007), s kiemelték annak kapcsán, hogy vidéki, falusi környezetben valósul meg a helyi szereplök összefogásával, hozzájárul a természeti környezet megóvásához és a vidéki életkörülmények javításához. Különbséget tettek továbbá a vidéki (falusi) turizmus és a falusi vendéglátás között. Ez utóbbit a vidéki (falusi) turizmus részeként, annak speciális elemeként, konkrétan a szállásadói tevékenységgel azonosítva határozták meg.

$\mathrm{Az}$ utóbbi bő egy évtizedben más hazai szakmai berkekben is egyre inkább elmozdulás történt ${ }^{4}$ az átfogóbb és bővebb „vidéki turizmus” terminológia használata felé. Számos kutató, köztük Fehér és Kóródi, továbbá Dávid, valamint Kovács is ezen elnevezés használatát tartja célszerünek, s a turisztikai termékre helyezi a hangsúlyt, amikor azt nem egy konkrét turizmusfajtának, hanem azok egyfajta halmazának tekinti, amely „vidéki környezetben, vidéki jellegü fogadókapacitással, a vidékre jellemző szolgáltatásokat” kínál (DÁVID 2007, FEHÉR - KÓRÓDI 2009, KOVÁCS 2015). A vidéki turizmus tehát jóval bővebb kategória a falusi turizmusnál. Utóbbi a vidéki turizmus egyik kínálati formájának tekinthető. Szabó is a falusi turizmus és a vidéki turizmus szoros kapcsolatát emeli ki, s aláhúzza fontos szerepét a vidéki területek természeti értékeinek, tárgyiasult és szellemi örökségének megőrzésében és ápolásában (SZABÓ 2012). Szinte valamennyi idézett szerző kiemeli a vidéki turizmus kapcsán annak erős kötődését a helyi erőforrásokhoz, továbbá a vidékfejlesztésben betöltött egyre fontosabb szerepét.

\footnotetext{
3 „A hazai lakosság és a külföldi vendégek, turisták szabadidő szükségleteinek, vidéki, falusi környezetben való, minél szélesebb körü kielégítéséhez nélkülözhetetlen, minőségi infrastruktúra és sajátos szolgáltatások kialakítása, fenntartása, prezentálása, a természet és a környezet egyidejü megóvása, valamint a helyi lakosság, intézményeinek és a helyi vállalkozások összefogása, életkörülményeinek javítása a vidéki (falusi) turizmusban szolgáltatást nyújtók szakmai együttmüködése mellett.” (CSIZMADIA 2013: 5)

${ }^{4}$ Jancsik már az 1990-es évek végén a vidéki területek meghatározó jellegét emelte ki a fogalom tartalmát illetően. A rurális környezetben, azaz városi övezeteken és üdülötelepeken kívül megvalósuló turizmust tekintette vidékinek (JANCSIK 1998).
} 


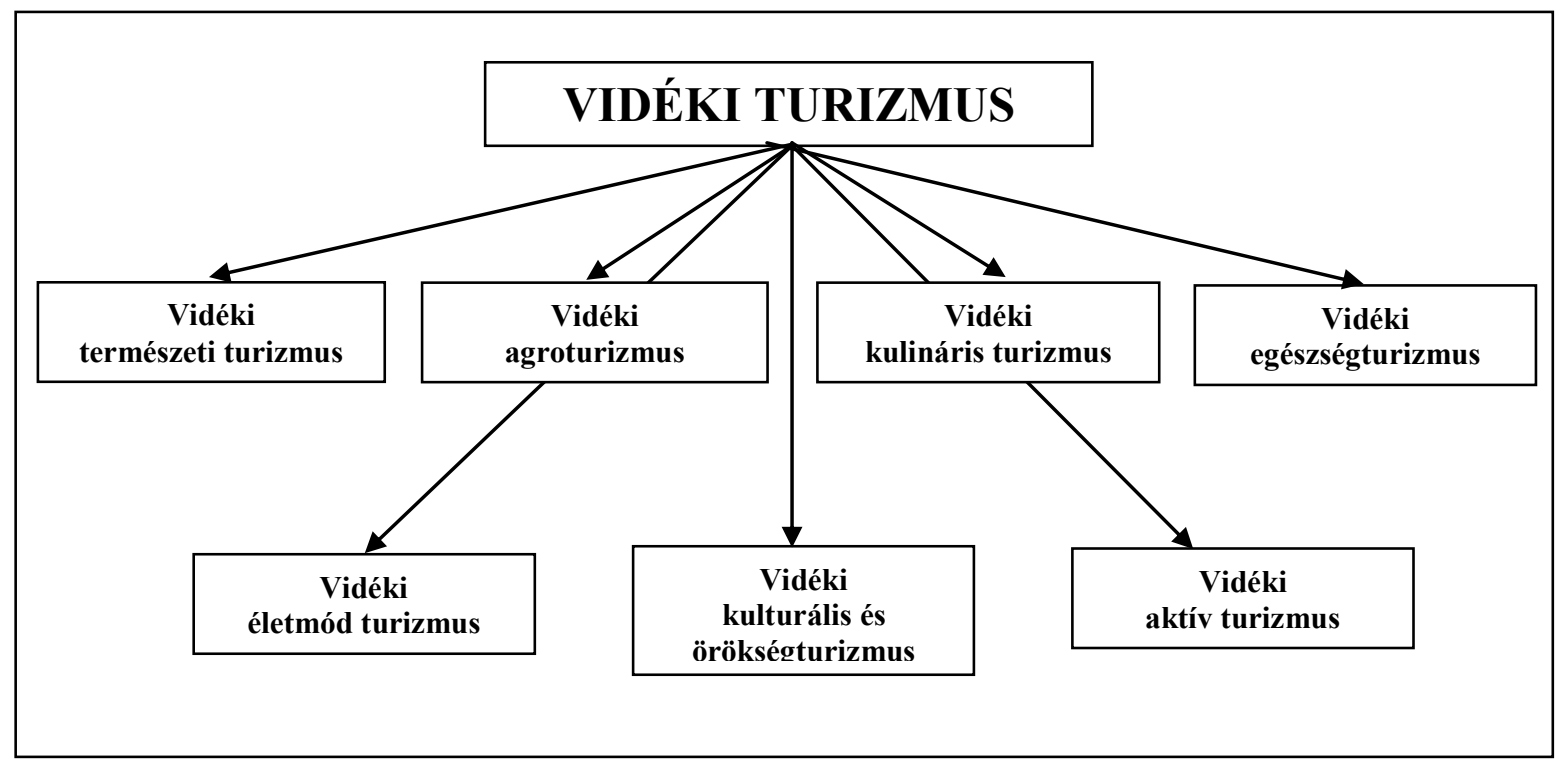

Forrás: Dávid L. (2007.): A turizmus földrajzi alapjai nyomán saját szerkesztés

A vidéki területek turizmusának fogalmi megközelítései mind-mind egy-egy fontos aspektusát emelték ki a jelenségnek, de úgy érzem egy sem tért ki kellő mértékben annak eröteljes térbeli, térspecifikus vonásaira. Vidékföldrajzi szempontú megközelítésem következtében érthető, hogy a vidéki tér és annak turizmusa közötti összefüggést szorosnak vélem, és ennek felhasználásával tartom célszerünek egy újszerü koncepció felvázolását.

\subsection{A ,vidékturizmus" értelmezési lehetősége}

A rurális turizmus fentebb ismertetett nemzetközi és hazai megközelítéseiből világosan kitünt, hogy nagyon sokszínü, szinte országonként változó annak elnevezése és tartalma. Az Alföld turizmusa kapesán azonban a nemzetközi és hazai elméleti megközelítéseket felhasználva felvázolható egy sajátos vidékföldrajzi irányultságú, a térség turizmusának jellegzetességeit jobban magába integráló elméleti koncepció, melyet nevezhetünk ,vidékturizmusnak”.

Mivel az Alföld szinte egésze - néhány urbanizáltabb központtól eltekintve - vidéki térnek tekinthető, turisztikai kínálata is ebben a térben fejlődött ki és funkcionál. Meglátásom szerint a vidéki tér, az Alföld jellegzetes vidékisége erősen meghatározza a térség turisztikai kínálatának legjellemzőbb vonásait is. Álláspontom szerint tehát az alföldi területek turizmus-rendszerének vidékföldrajzi szempontú értelmezése során a vidék, mint jellegzetes földrajzi tér állítható középpontba. Ennek erőforrásaiból a turisztikai kínálat 
valóban létrejön, s a vidéki tér meghatározó turisztikai szolgáltatások igénybe vétele, „fogyasztása” során is. Úgy vélem elméleti szinten, koncepcionálisan a Bernard Lane által felvázolt és fentiekben részletesen ismertetett modell - némi gondolati kiegészítéssel alkalmas lehet arra, hogy annak mentén átfogóan értelmezzük az Alföld vidéki térségeinek turizmusát. Könnyen belátható, hogy az Alföldön is megtalálhatók a Lane koncepciójában feltárt vidékies, átmeneti és városias jellegü turisztikai termékek. Érdemes megvizsgálni ezek térbeli előfordulását olyan szempontból, hogy milyen (vidékies vagy városias, esetleg átmeneti) térben érhetők el, milyen tértípus erőforrásaiból keletkeztek.

Mindez egy koordináta rendszerben vizuálisan is ábrázolható, ahol a vízszintes tengelyen az origótól indulva a vidéki tértől a városias felé mozdulunk el. A függőleges tengelyen pedig a kiindulóponttól távolodva a vidékies turisztikai termékektől a városiasok felé haladunk.

\section{6. ábra: A „vidékturizmus" értelmezése}

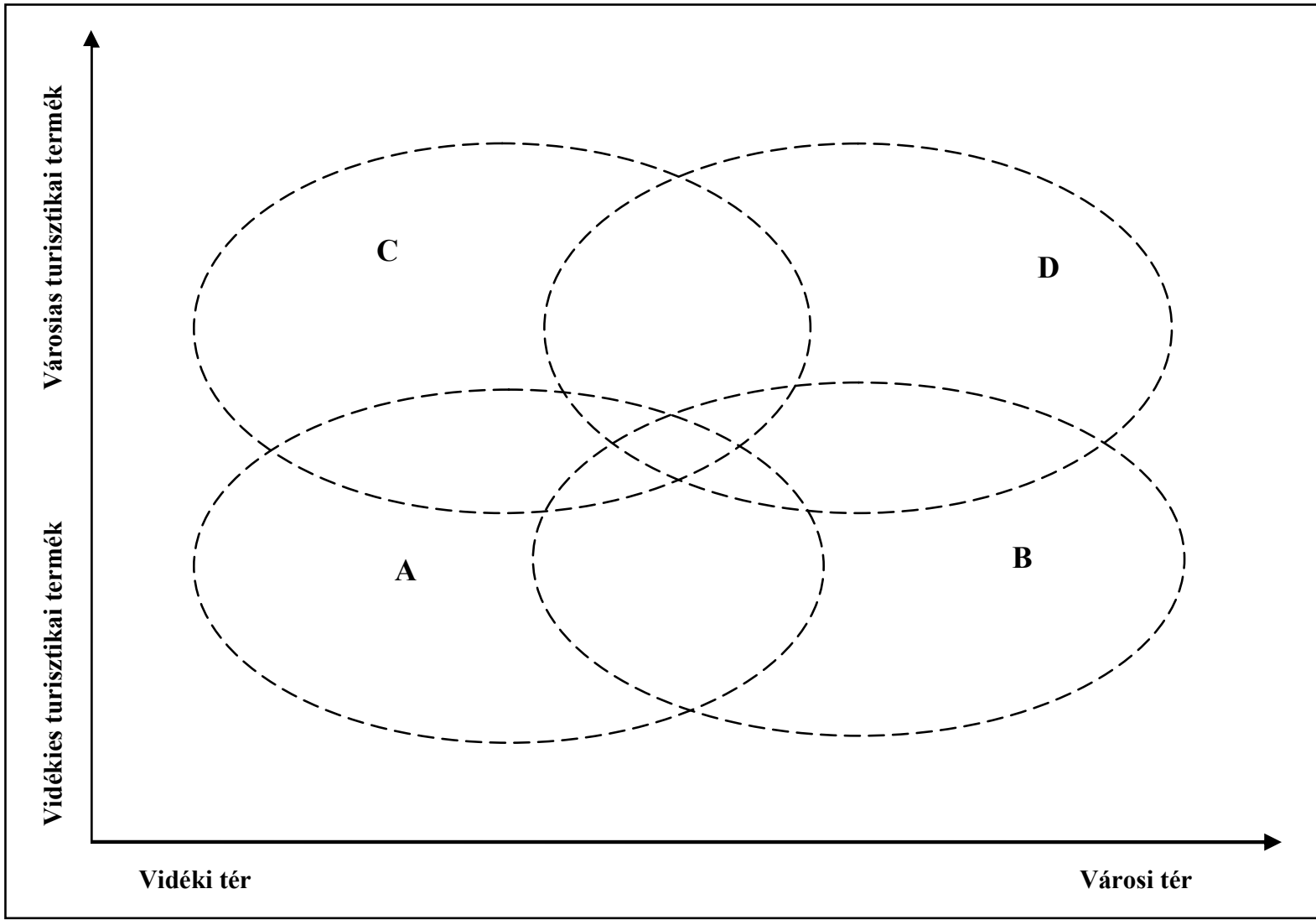

Forrás: saját szerkesztés

A tértípusok és a turisztikai termékek lehetséges kombinációit tekintve négy fő típus jelölhető ki:

- A: Vidéki térben - vidékies turisztikai termék

- B: Városi térben - vidékies turisztikai termék 
- C: Vidéki térben - városias turisztikai termék

- D: Városi térben - városias turisztikai termék

(Lane is utalt rá léteznek átmeneti turisztikai termékek, sőt akár átmeneti tértípusok is. Ezekre utalnak az ábrán a halmazok közötti átfedések, metszetek.)

Mint korábban jeleztem megközelítésemben a nagyon fontos a térbeliség, vagyis az, hogy az adott turisztikai termék, milyen típusú térben fordul elö, illetve vagy érhető el. Az ábrán szereplő „A” típus esetén egyértelmüen a vidékiség, a vidéki tér dominál. Konkrét példával illusztrálva klasszikusan ilyen lehet az Alföldön egy falusi-tanyai vendégfogadó programkínálata, amelynek keretében a vendégek megismerkedhetnek a gazdálkodással, a vidéki életmóddal.

A „B” típus esetén ugyan a tér városias jegyeket mutat, de a turisztikai termék inkább vidékies. Erre példa lehet az alföldi városias-mezővárosias településein egy-egy ma is jellemzően igénybe vehető hagyományőrző kézműves vagy gasztronómiai program.

A „C” típus esetén termék városias jegyeket mutat, de vidékies környezetben érhető el a turisták számára. Ezt példázzák az Alföldön, vidéki területeken is egyre elterjedtebb intenzív jellegü fürdő és wellness szolgáltatások.

A „D” kombináció a városi térben előforduló városiasnak tekinthető turizmusfajtát takarja. Ilyen lehet például a nagyvárosok kulturális turisztikai kínálata, mely kifejezetten városias térben valósul meg.

Koncepcióm szerint az alföldi „vidékturizmus” tágan vett értelmezésébe ez utóbbit kivéve valamennyi fentebb felsorolt kategória beletartozhat, s együttesen képezheti az Alföld nagyrégió rendkívül változatos, összetett turisztikai kínálatát és turizmusrendszerének gerincét. Sőt, még bizonyos megszorításokkal az alföldi városias térségekben előforduló inkább városinak minősíthető turizmusfajták is részét képezhetik, hiszen mint a korábban bemutatott vidéktipizálásokból látható volt a városias térségek aránya alacsony az Alföldön, csak néhány megyeszékhely járása tekinthető urbanizáltnak, $\mathrm{s}$ ezek városiassága sem mérhető nyugat-európai mércével. Emellett mint maga Bernard Lane is kifejtette koncepciójában, nehéz éles határvonalat húzni a városias és vidékies turizmusfajták között, széles köztes zóna és erőteljes keveredés jellemző.

A „vidékturizmus” tehát a falusi és vidéki turizmusnál jóval bővebb és tágabb megközelítése a vidéki területek turizmusának. Úgy vélem ezen újszerü, a térbeliséget előtérbe helyező megközelítés révén jobban és pontosabban feltárható az Alföld turizmusának belső lényegi tartalma, összetettsége és valódi ,alföldisége”. 


\section{A vidékgazdaság és a turizmus összefüggései}

Mint korábban utaltam rá a turizmus egyre nagyobb jelentőséggel bír az átalakuló vidéki térségek gazdaságában. E fejezetben a regionális fejlődési modellek, a helyi, belső erőforrások, a vidékgazdaság, a vidéktőke és a turizmus összefüggéseit vizsgálom.

\subsection{A regionális fejlődési modellek érvényesülése vidéki térségekben}

Hosszú idő óta foglakoztatja a kutatókat a regionális fejlődés mozgatórugóinak meghatározása: milyen okok és mely tényezők vannak hatással egy-egy térség fejlődésére.

A fejlődéselméletek igen sokféle megközelítésből vizsgálták a kérdéskört, s azok több történeti szakaszra bonthatók.

A hagyományos modellek kiindulópontja a klasszikus termelési tényezők, a munka és a tőke földrajzilag egyenlőtlen eloszlása, ami miatt egyenlőtlen gazdasági növekedés alakul ki, s a tőke oda áramlik, ahol bőséges és olcsó a munkaerő, a munkaerő pedig ellentétes irányba egészen a kiegyenlítődésig. Az agglomerációs modellek szerint a növekedési pólus stimulálja a többi terület gazdasági növekedését, mely a központi várost közvetlenül övező területek esetén is fejlődést indukál. A helyi miliő modell alapján a helyi tényezők (munkaerő képességei, technikai és szervezeti állapota, a know-how, szociális és ipari struktúrák, tőke- és munkaerő) meghatározóak a regionális fejlődésben. A területi innovációs modellek esetén pedig az újítások diffúziója jelentheti az adott térség növekedésének motorját (TERLUIN 2003).

Az 1990-es évektől a globalizáció felgyorsulásával párhuzamosan egyre inkább megerősödtek az endogén tényezőkre építő, egyben a lokalitás szerepét hangsúlyozó regionális fejlődési teóriák (LENGYEL 2012). Nyilvánvalóvá vált ugyanis, hogy egy adott terület fejlődését a globalizált világban is erőteljesen meghatározzák saját belső adottságai földrajzi fekvésétől kezdve, a természeti földrajzi adottságain át a társadalmi viszonyaival bezárólag. Bármennyire is globalizálttá vált ugyanis világunk, a termékek és szolgáltatások előállításához szükséges erőforrások továbbra is lokálisak, egy adott helyhez kötöttek (LENGYEL 2012.) Ennek nyomán egy-egy térség fejlödését a helyi és a globális 
erőviszonyok kölcsönhatása befolyásolja, s a globális kihívásokra adott helyi válaszok határozzák meg az adott térség gazdasági teljesítményét, sikerét vagy sikertelenségét.

Sajátos helyzetben vannak e tekintetben a vidéki térségek, ahol az elmúlt fél évszázadban példa nélküli gyorsaságú társadalmi-gazdasági változások következtek be. Fejlődési modelljeiknek a szakirodalom szerint három fő típusa különbözethető meg: az exogén, illetve endogén tényezőkön alapuló, valamint az ezek kombinációjaként jellemezhető alapuló vegyes (exogén/endogén) fejlődést leíró megközelítések.

Az 1970-es évekig az exogén szemlélet uralkodott Nyugat-Európában (TERLUIN 2003). Eszerint a fejlődés elsősorban külső tényezők által meghatározott, kívülről determinált. Ez azonban nem volt elég a vidéki területek mezőgazdaságának modernizációjához, a vidék gazdaságnak stabilizációjához. A következő szakaszban a növekedési pólus elméletet preferálták. Azonban ez sem hozott áttörést, nem alakult ki ennek nyomán sem fenntartható gazdaságfejlődés a vidéki térségekben.

Az elmúlt negyed században mind hangsúlyosabbá vált az endogén tényezőket előtérbe helyező modell, mely szerint a fejlödés föként helyi impulzusok által, helyi erőforrásokból táplálkozik, $\mathrm{s}$ az exogén modellel ellentétben helyben maradhat a megtermelt haszon is, döntő cél lett tehát a helyi értékek fenntartható hasznosítása. E csoporton belül további három fontosabb elmélet látott napvilágot (TERLUIN 2003):

A ,közösség által vezérelt vidékfejlesztés” elmélete (MURRAY-DUNN 1995), amely a helyi szereplők önsegítő képességén alapszik, s mintegy előfeltétele a fenntartható gazdaságfejlesztésnek. A modell az alulról jövö, a helyi közösség önrendelkezésén alapuló kezdeményezésekre, valamint a helyi, regionális és nemzeti hatóságok közötti együttmüködésre alapoz. Mára egyre szélesebb körben alkalmazzák az Európai Uniós fejlesztéspolitikában.

Bryden ,állandó erőforrás” elmélete a vidéki erőforrások viszonylagos állandóságára épül (BRYDEN 1998). Meglátása szerint a globális folyamatok változó erőforrásaihoz képest a vidéki erőforrások stabilnak tekinthetők, s ez akár jelentős versenyelőnyt is biztosíthat. Az állandó erőforrások közé sorolta a társadalmi tőkét, a kulturális tőkét, a környezetvédelmi tőkét és a helyi tudástőkét. Bryden elmélete alapján a vidéki területek gazdasági fejlődése a tárgyi és állandó erőforrások kombinációjától és egymással való kölcsönhatásától függ.

A közösségfejlesztés sajátos, kreatív destrukciós modellje (MITCHELL 1998) a vidék, a vidéki idill áruvá válásával, módosulásával foglalkozik. Ezen folyamat során vidéki erőforrások és örökség egyre inkább széles tömegek által megvásárolt és fogyasztott 
„árucikké” válnak. A növekvő fogyasztás egyre nagyobb beruházásokat generál egészen addig, amíg akár „túlhasználat” állhat elő, károsodnak a vidéki erőforrások, eltünik a vidéki idill. Ennek nyomán alakultak ki például az ún. „heritageshopping” falvak Kanadában (Nelson és St. Jacobs) és Spanyolországban (Albarracin). E megoldás létrejöttéhez három tényező szükséges: a vállalkozói beruházások, a felfutó fogyasztás és közben a vidéki örökség sajnálatos lerombolása. Mögöttes feltétele továbbá az erőteljes vállalkozói értékesítési szemlélet és a marketing, valamint az, hogy a vidékies gyökereit kereső, nosztalgiát igénylö posztmodern fogyasztót sikerüljön rávenni ezen javak „megvásárlására”. A jelenség egy-egy terület túlzott mértékü vidékturisztikai hasznosítása kapcsán is reálisan előfordulhat.

A vegyes (endogén/exogén) fejlesztési modell az endogén és exogén megközelítés helyett a helyi és külső erők összjátékát, kölcsönhatását emeli ki a vidéki régiók fejlődésével kapcsolatban. A globalizált világban a vidéki térségek aktorai egyaránt részt vesznek helyi és külső hálózatokban, de ennek mértéke, iránya és intenzitása régiónként igen eltérő. Ez a vidékfejlesztési megközelítés hálózatok sajátosan komplex hálójának tekinthető, amely a helyi erőforrásokra épül, a folyamatok pedig a külső és belső erők kölcsönhatásától függően zajlanak (LOWE 1995). Lényegében ezen alapvetésekre épül a korábban bemutatott Integrált Rurális Turizmus (IRT) modellje is.

Természetszerüleg kapcsolódások és átfedések fedezhetők fel az általános regionális és vidéki térségekre specifikált fejlődési elméletek között. A növekedési pólus elmélet sok tekintetben hasonlóságot mutat az exogén fejlesztési megközelítéssel, továbbá az agglomerációs modellekkel, az endogén tényezőkre építő teória pedig a helyi miliő modellel.

Jóllehet nincsenek univerzális, általánosan alkalmazható modellek, több európai szintü kutatás, közte a RUREMPLO projekt mégis azt igazolta, hogy a leghatékonyabb fejlesztési módszerek közé tartozik a vegyes (exogén/endogén) módszer, továbbá Bryden elmélete. Ezek elsősorban a helyi erőforrások, valamint a helyi és külső hálózatok szerepének fontosságát hangsúlyozzák.

Mindezekböl kiindulva primer kutatásaim során (ld. 6.5. fejezet) az Alföld turizmusa kapcsán releváns belső erőforrásokat, továbbá a szektor szereplői közötti együttmüködéseket vizsgáltam. 


\subsection{A helyi erőforrások és a vidékgazdaság}

A globalizáció világméretü jelenségének egyik hozadékaként - mint már említettem megnőtt a lokalitás és a helyi erőforrások jelentősége, felértékelődtek a még viszonylag eredeti állapotukban megmaradt vidéki térségek. Enyedi a globalizáció területi fejlődésre gyakorolt hatásainak vizsgálata kapcsán pontosan erre, a helyi adottságok szerepének jelentőségére és annak változására hívta fel a figyelmet. Megjegyezte azonban, hogy nem minden helyi tényező növeli a versenyképességet, csak a másutt elő nem forduló, vagy pl. a speciális tudáson alapuló lokális adottságok. A hagyományos ágazatok is lehetnek ilyenek, ha különleges, csak az adott helyen elöállítható terméket produkálnak. (ENYEDI 2000). Több kutató is rámutatott, hogy a földrajzi tér is különös erőforrássá vált, és a tér minden egysége a különböző erőforrások egyedi, más térségektől eltérő kombinációját nyújthatja (BOKOR 2003, LENGYEL 2012).

A lokális, vidéki erőforrások fogalmi meghatározásával kapcsolatos álláspontok is igen sokfélék és szerteágazóak. Általában véve nem feltétlenül jelentenek kézzel fogható dolgokat, sokkal inkább egy kulturálisan meghatározott absztrakt fogalmat takarnak. Cloke és Park általános meghatározása szerint minden olyan dolog vidéki erőforrásnak tekinthető, amely társadalmilag értékes lokális célok elérésének eszközéül szolgálhat (CLOKE PARK 1985). A célok jellemzője, hogy azok rendkívül széleskörüek, valamint térben és időben erőteljesen változhatnak. Hasonlóképpen értelmezést ad Tóth is, aki szerint minden olyan eszköz, körülmény vagy lehetőség, például a természeti környezet valamely eleme erőforrás, ami a gazdaság egy adott fejlettségi szintjén az emberi szükségletek kielégítésének alapja, illetve forrása lehet (TÓTH 1988).

A globalizáció folyamataira adott válaszok, az alkalmazkodás értelemszerüen a helyi sajátosságoktól függően más és más lehet, melyet döntően befolyásolnak a térségre jellemző belső tényezők, ún. endogén erőforrások. Póla a vidéki térségek belső erőforrásokra alapozott fejlesztését vizsgálva a helyi, belső erőforrásokat az alábbi csoportokba sorolta:

- Földrajzi helyzet;

- Természeti erőforrások: tájkép, talaj, víz, éghajlat, növényzet és állatvilág, nyersanyagok, megújuló energiák);

- Humán erőforrások: speciális tudás, képzettség, kreativitás, szorgalom;

- Társadalmi erőforrások: identitás, társadalmi kapcsolatok, bizalom, együttmüködés; 
- Intézményi környezeti erőforrások: helyi gazdaság és intézmények müködése, szervezettsége, a közöttük lévő együttmüködés;

- Speciális termékekhez kapcsolódó erőforrások: speciális tradícionális és innovatív helyi termékek (PÓLA 2014).

Mindezekből következően a vidékgazdaság definiálására is számos szerző tett kísérletet, több szempontból megközelítve a fontos és sajátos fogalmat. Egyikük volt Fehér, aki abból indult ki, hogy a vidék, mint a tér egy speciális része, sajátos, komplex természeti, gazdasági és társadalmi egység (FEHÉR 2005). A vidékgazdaságot „a vidéki területeken található, nagy részben földhasználati irányultságú regionális gazdaságként” definiálta, amely magában foglalja az adott területen gazdasági tevékenységet végző és fogyasztó szereplőket, az ott fellelhető és felhasználható helyi erőforrásokat, az adott területen müködő vállalkozásokat, háztartásokat, civil szférát, hatóságokat és intézményeket, valamint az általuk fenntartott belső és külső kapcsolatrendszert, illetve a gazdasági tevékenységek kereteit jelentő struktúrákat (FEHÉR 2005). Koncepciója szerint tehát a vidékgazdaság az adott terület belső erőforrásain alapul, amelyet az ott müködő szereplők: a vállalkozások, az önkormányzatok, a civil szervezetek és természetes személyek hasznosítanak. Lényegében ugyanígy vélekedett Bozsik is, amikor a vidékgazdaság kapcsán megjegyezte, hogy az endogén tényezőkre épül, és csak kis mértékben használ kívülröl származó erőforrásokat (BOZSIK 2010).

A külföldi kutatók megközelítései több ponton eltérnek ezektől az álláspontoktól. Ward definíciós kísérletében a vidéki térségek sokszínűségére helyezte a hangsúlyt. Kiemelte, hogy a vidéki térségek igen heterogének, így azok gazdasága is sokféle, s nem egy általánosan értelmezett vidékgazdaság létezik, hanem „,vidékgazdaságok” („rural economies”), melyek sok szállal kötődnek a városi gazdaságokhoz is (WARD 2008). Angolszász példákból kiindulva a „föld-alapú” „hagyományos vidékgazdaság” fogalmának bővítését, átgondolását javasolta. Érvelését arra alapozta, hogy a szorosan vett agráriumot illetően az angliai farmerek több mint 50 \%-a már nem csak agrár tevékenységet folytat, és a vidéki térségek lakóinak kevesebb mint $3 \%$-át foglalkoztatja a mezőgazdaság és a GDPből is $1 \%$ alatti a részesedése (OLÁH 2003, WARD 2008). A vidéki vállalkozások zöme sem mezőgazdasági tevékenységet folytat ma már, hanem a kereskedelem és a turizmus, az oktatás és egészségügy, az ipar, valamint a pénzügyi szolgáltatások terén müködik. Hasonlóan vélekedett Roberts is, aki szerint szintén nem egyetlen vidékgazdaság létezik, az egyes térségek gazdasága inkább vegyes gazdaság, városi és vidéki területeket egyaránt magába foglal, melyek szorosan kapcsolódnak egymáshoz (ROBERTS 2002). Analóg 
módon Marini és Mooney is azt hangsúlyozta, hogy a város és a vidék szervesen kötődnek egymáshoz, ugyanígy a gazdaság egésze sem választható el a politikai, kulturális, társadalmi tényezőktől és viszonyoktól (MARINI - MOONEY 2006).

Az erőforrások körét nehéz egyszerüen, egzakt módon meghatározni, hiszen egy-egy tudományterület szempontjából nagyon eltérőek lehetnek a megközelítések. A hard elemek mellett legalább olyan fontosak például a szoft tényezők. Erre hívta fel a figyelmet Nógrádi is. Meglátása szerint a vidékgazdaságok fejlödéséhez először „társadalmi csodára van szükség”, amelyet maga az adott helyi-vidéki közösség tud megvalósítani azáltal, hogy a lokális társadalom belső erőforrásait, a helyi kultúrát, a munkakultúrát és az értékek mentén történő együttműködést mozgósítja a fejlődés érdekében (NÓGRÁDI 2010).

Mára a vidékgazdaságok is az ún. a posztmodern fejlődési szakaszba jutottak, melynek fő jellemzője - mint fentebb láttuk - a mezőgazdaság alacsony részesedése a GDP-ből és a foglalkoztatásból, ugyanakkor át- és felértékelődnek az indusztriális fejlődési szakaszban kis jelentőséggel bíró tényezők és erőforrások, diverzifikálódik és multiplikálódik a vidékgazdaság. Bővülnek és előtérbe kerülnek a vidék belső lényegéből fakadó és benne akár rejtetten müködő funkciók. S ezek mentén a posztmodern vidékgazdaság sokkal nagyobb érték előállítására képes, mint a korábbi (OLÁH 2005).

\subsection{A vidéktőke és a turizmus}

Mint korábban a regionális fejlődési elméleteknél röviden jeleztem, hogy napjainkra egyre inkább teret nyertek az endogén tényezőkre épülő modellek, megnőtt a térbeliség szerepe, felértékelődött a belső erőforrásokkal rendelkező tér szerepe. Ezek nyomán a klasszikus termelési tényezőnek számító tőke fogalma is új dimenziókkal bővült, kialakult a „területi töke” fogalomrendszere. Ennek alaptényezői Camagni szerint a közjavak, a magánjavak, a társadalmi tőke és a humán tőke, melyek egyben az endogén regionális fejlődés forrásainak is tekinthetők (LENGYEL 2012).

A területi tőke egy sajátos változatának tekinthető a vidékei területeken megjelenő „,vidéktőke”. Ennek megjelenésével a nyugat-európai kutatók még inkább hangsúlyozni akarták a vidéki területek belső erőforrásainak jelentőségét. Definiálására az angliai Vidékfejlesztési Ügynökség tett kísérletet. Értelmezésük szerint a „,vidéktőke” a vidék sajátos értékeket képviselő szövete a falvakkal és városokkal (GARROD - WORNELL YOUELL 2006). 
A vidék szövetének összetevőit Garrod és szerzőtársai három komponens elegyeként határozták meg. Ezek a természeti tényezők, az épített környezet (közte a vidéki települések) és a szociális tényezők (pl. helyi kulturális hagyományok).

Értelmezésükben a vidéki tőke alkotóelemei az alábbiak:

- Táj, tájkép

- Vadvilág, állat- és növényfajok

- A biológiai sokféleség

- Földtani és talajadottságok

- Levegő és levegőminőség

- Sövények és táblahatárok

- Mezőgazdasági épületek

- A vidéki települések, az elszigetelt lakóhelyek/tanyák és a mezővárosok

- Történelmi emlékek, mint például a történelmi épületek, ipartörténeti emlékek

- Útvonalak, ösvények, lovastúra útvonalak, sávok és utak

- Patakok, folyók, tavak

- Víz és vízminőség

- Erdök és ültetvények

- Jellegzetes helyi szokások, nyelvek, népviseletek, tradícionális élelmiszerek, kézmüves termékek, fesztiválok, hagyományok, vidéki életmód (GARROD WORNELL - YOUELL 2006).

Koncepciójukban kiemelik a „vidéktőke” és a turizmus kölcsönös egymásrautaltságát, kölcsönkapcsolatát, amivel a belső erőforrások, „vidéktőke” és a turizmus közötti erős kapcsolatot támasztották alá (GARROD - WORNELL - YOUELL 2006). Elemzésükben kifejtették, hogy a turizmus szempontjából valamennyi vidéki tőkeelem - bár különböző mértékben - vonzhat turistákat és élményt biztosíthat számukra, igénybe vehetők a turisztikai értékláncban. A „,vidéktőke” alapvető összetevője a vidéki turisztikai vállalkozások eszközkészletének, az általuk kínált attrakcióknak. Persze nem az egyetlen meghatározója a turisztikai élménynek, hiszen abban nagy része van más támogató intézményeknek, a magas színvonalú szolgáltatásoknak és a kiváló ügyfélkiszolgálásnak.

Megjegyzendő azonban egy - a szerzők által is elismert - hiányossága fenti fogalmi megközelítésnek, mégpedig, hogy nem hangsúlyozza eléggé a tőke pénzdimenzióját a kifejezésben. Javára írható viszont, hogy a vidék „,szövetét” tőkeként értelmezi, és rávilágít arra, hogy mindez meghatározó szerepet játszhat a vidéki vállalkozások életében. 
Meghatározó gondolatmenetükben a fenntartható fejlődés elveinek alkalmazása, melyet a vidéki problémák kezelésében is követendőnek tartanak. Eszerint a mai generáció életminősége attól függ, hogy milyen bölcsen használták fel az elődeiktől kapott erőforrásokat, vagy megközelítésünk szerint ezt a sajátos „tőkét”. Ugyanezen analógia alapján a jövő generációk élete és lehetőségei attól függenek, hogy mi a jelenkorban hogyan gazdálkodunk az erőforrásokkal. Az a tőkeállomány, amit átadunk utódainknak nem lehet kevesebb és rosszabb minőségü, mint amit örököltünk. Ezt ,állandó tőke szabály”-nak nevezték, mely a fenntartható fejlődés gondolatának központi eleme.

Garrod és szerzőtársai koncepciója mentén három fontos haszna van annak, ha a vidéki területek belső erőforrásait „,vidéktőkeként” értelmezzük. Egyrészt ezzel ráirányítjuk a figyelmet a „,vidéki turizmus értéklánc” valamennyi szakaszában játszott létfontosságú szerepére. Ez azt is jelenti, hogy a belső erőforrások és ezáltal vidék minősége igen nagymértékben meghatározza a turizmus által nyújtható élményt (GARROD - WORNELL - YOUELL 2006). Ez egyben elvezet a vidéktőke fogalmának alkalmazása révén keletkező második haszonhoz, ami rávilágít arra, hogy a turizmus terén tevékenykedő vállalkozásoknak fenntartható kapcsolatot kell kialakítania vidékkel, ahol működnek. A „,vidéktőke” nélkülözhetetlen inputját jelentik tehát a vidéki környezetben létrejövő turisztikai termékeknek. Ha csökken a minősége az valószínűleg tükröződni fog látogatások csökkenésében is. S ez fordítva is igaz, ugyanis ha a turisztikai vállalkozások a vidéktőke védelmébe és fejlesztésébe fektetnek be, az növelheti az eladható végtermék minőségét. Ha a turizmus terén müködő vállalkozások szisztematikusan nem képesek vagy nem hajlandók ezen beruházásokat megtenni, akkor kudarcra vannak ítélve. Fontos lehet végül a vidéki belső erőforrások ,vidéktőkeként” való újragondolása, mert segíthet felismerni azon tevékenységeket, amelyek károsítják vagy lebontják ezt a sajátos tőkeállományt. Ilyen lehet akár - ahogyan azt a regionális fejlődés kreatív modellje is bemutatta - a rosszul menedzselt turizmus is. Az ilyen tevékenységeket vagy ki kell tiltani, vagy, ha úgy ítélik, hogy jelentős hozzájárulása vidéki közösség életéhez, akkor úgy kell kezelni, hogy minimalizálják a „vidéktőke” állományban okozott kárt (GARROD - WORNELL YOUELL 2006).

Nyugat-Európában egyre inkább a vidékgazdaság integráns részének tekintik a turizmust, kiemelve annak a vidéki lokális, térségi erőforrásokat konzerváló, megőrző hatását (GARROD - WORNELL - YOUELL 2006). Mára sok helyen a vidékturizmus vált sok helyi közösség tartóoszlopává, mivel a mezőgazdaság szerepét pótolja a vidékgazdaságokban, sőt számos angliai vidéki térségben ma már jelentősebb szereppel bír, 
mint az agrárium. Németországban már az 1990-es évek közepén a GDP 8 \%-át tette ki a vidéki területek turizmusának hozzájárulása, messze meghaladva a mezőgazdaság $3 \%$-os részesedését (OLÁH 2005).

Vonzó és élénk vidék nélkül a turizmus nem képes értékesíthető turisztikai terméket előállítani és eladni a fogyasztóknak, a látogatóknak, a turistáknak (GARROD WORNELL - YOUELL 2006). A vidéki táj valamennyi eleme beleértve a természeti környezetet, a településeket és a humán tényezöket a turizmus számára valamilyen erőforrásként hasznosítható.

7. ábra: Az erőforrások, a „vidéktőke” és a turizmus kapcsolata a vidéki térségekben

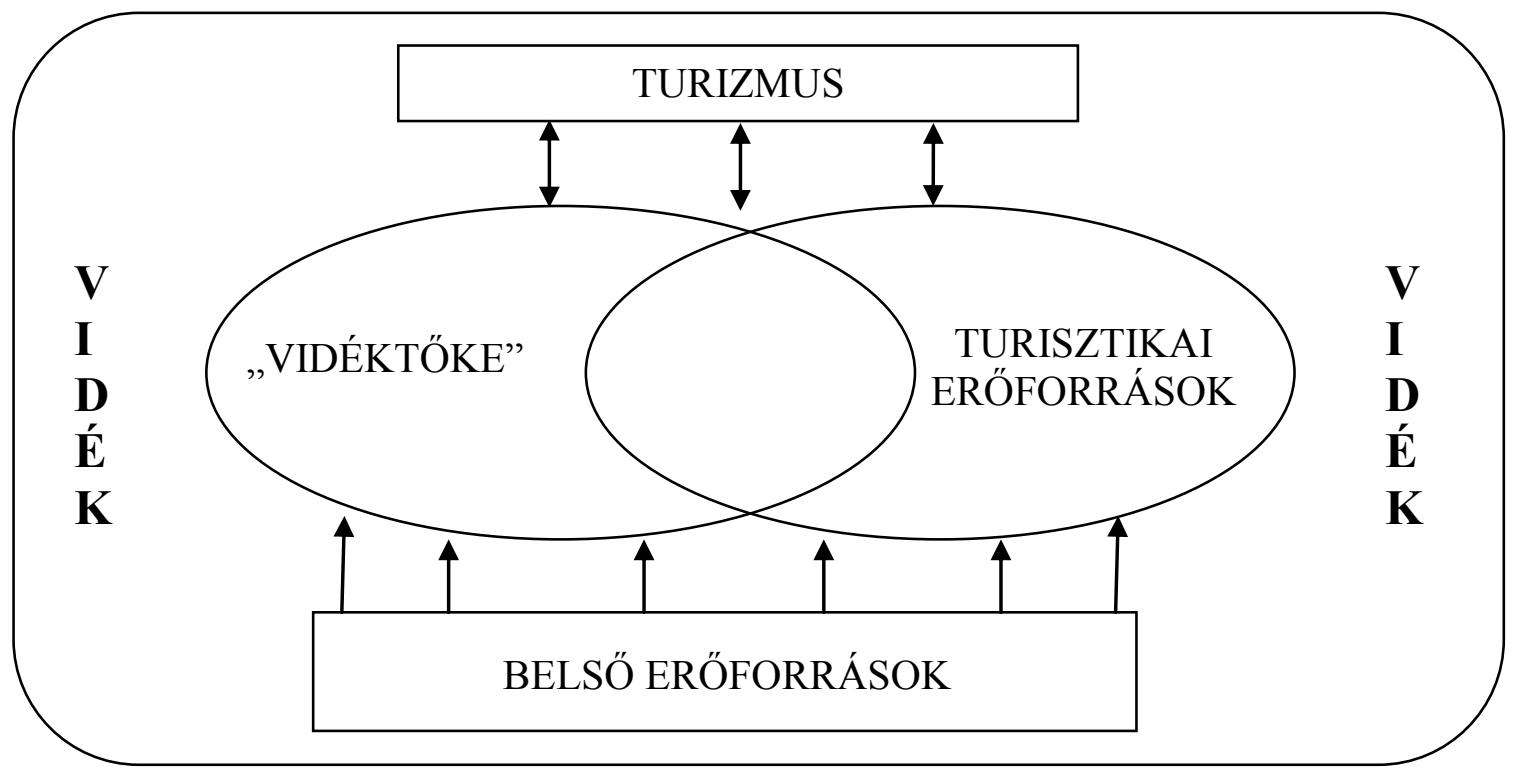

Forrás: GARROD-WORNELL-YOUELL (2006) nyomán saját szerkesztés

\subsection{A turisztikai erőforrások}

A turisztikai erőforrások áttekintésére több tudományág fogalomrendszere alapján is lehetséges. Témám szempontjából értelemszerüen legfontosabb a földrajzi szempontú megközelítés. E tekintetben kiemelhető, hogy turizmus erőforrásai a földrajzi környezet különböző elemeiből származtathatók, a természeti és kulturális erőforrások a vonzerők alapját képezik. Az infrastruktúra, közlekedés és információtechnológia; a turisztikai szuprastruktúra és az emberi erőforrások pedig ezekhez társulva, a turizmus rendszerének müködésében játszanak fontos szerepet. Mindezek mellett egy sajátos vonása is kiemelhető a turizmus rendszerének, mely szerint a turisztikai desztinációk létrejöttében 
megkülönböztetett jelentősége a „hely szellemének” (genius loci), amit az egyes erőforrás elemek alakítanak és formálnak (JÓNÁS-BERKI 2010).

A turizmus erőforrásainak másik - közgazdasági irányultságú - megközelítése szerint a többi társadalmi-gazdasági jelenség müködéséhez hasonlóan ezen ágazat müködéséhez is erőforrások szükségesek. A klasszikus közgazdaságtan alaptétele szerint a javak előállításához termelési erőforrások kellenek. A közgazdászok ezek közé sorolják a földet (a természeti erőforrásokat), a munkát és a tőkét (MICHALKÓ 2007). Mivel a turizmus, más ágazatokkal fennálló kapcsolatai miatt nem egy jól körülhatárolható gazdasági ágazatnak tekinthető, így a termelési tényezők fogalmát is „turizmus specifikusan” kell értelmezni (DÁVID - JANCSIK - RÁTZ 2007). Ennek kapcsán három sajátosság emelhető ki. Az első - az általam követni szándékozott földrajzi szempontú megközelítés szempontjából a legfontosabb - a helyettesíthetőség kérdése, vagyis az, hogy a turizmus által hasznosított erőforrások egy része térspecifikus, egyedinek tekinthető, mással nem helyettesíthető, a földrajzi tér is erőforrás. A második jellegzetesség, hogy a turisztikai termékek létrejöttében nem csak a magánjavak, hanem jelentős részben a közjavak ${ }^{5}$ és a szabad javak ${ }^{6}$ is szerepet játszanak. (DÁVID - JANCSIK - RÁTZ 2007). Harmadik specifikumként megjegyzendő a turisztikai termék összetevőinek létrehozásába maga a fogyasztó, a turista is tevékenyen részt vehet azáltal, hogy saját maga állítja össze a felkínált lehetőségekből a számára szükséges kombinációt.

Ezen sajátosságok figyelembe vételével a turisztikai erőforrások Dávid-Jancsik-Rátz modellje szerint az alábbiak szerint értelmezhetők. A föld a természet egészeként azonosítható. A klíma, a tájkép, az növény- és állatvilág, a környezet állapota kiemelt szerepet játszik a turisztikai termékek létrejöttében, azok alapját képezi. A munka, a humán erőforrások összességének tekinthető, s két nagy alegységre bontható. Részét képezik egyfelől az ágazatban dolgozó munkaerő mennyiségi és minőségi jellemzői, másfelől a fogadóterület lakosságának beállítottsága, szokásai, hagyományai, attitűdjei. A tőkejavak is speciális értelmezést kap turisztikai aspektusból. Az ember által létrehozott tőke jellegü javak (pl. kastélyok, várak, templomok) alapjában véve nem turisztikai hasznosítás céljából jöttek létre, viszont gyakran részét képezik a turisztikai erőforrásoknak. Így az ágazat számos, nem saját maga által létrehozott tőkejavat használ. Ezek alapján a turisztikai

\footnotetext{
${ }^{5}$ Az emberi tevékenység nyomán létrejövő javak, amelyek oszthatatlanok, vagyis a használatukból eredö elönyök egyéni szinten nem differenciálhatóak, pl. közbiztonság, környezetvédelem, nemzetvédelem (DÁVID L. - JANCSIK A. - RÁTZ T. 2007).

${ }^{6}$ A természetben korlátlanul rendelkezésre álló, ingyenesen használható javak, pl. napfény, levegő (DÁVID L. - JANCSIK A. - RÁTZ T. 2007).
} 
erőforrások közé tartoznak tehát a természeti erőforrások, a kulturális erőforrások, a humán erőforrások és az infrastrukturális erőforrások, valamint ötödikként a pénzügyi erőforrások is (DÁVID - JANCSIK - RÁTZ 2007). Ez utóbbiak jóllehet közvetlenül nem a turisztikai termék alkotóelemei, viszont a termékfejlesztés közgazdasági-számviteli értelemben vett forrásai, s ezáltal áttételesen mégis a turisztikai erőforrások közé sorolhatók.

Látható tehát, hogy többféle megközelítés szerint a turizmus rendszerének alapelemét jelentik a lokális, belső erőforrások, melyekből létrejöhetnek a vonzerők, attrakciók. Az erőforrások azonban csak potenciális vonzerőnek tekinthetők, s csak akkor válhatnak valódi vonzó tényezőkké, ha a megfelelő szolgáltatásokkal (pl. idegenvezetés, egyéb programok, szállás, vendéglátás, stb.) kiegészülnek és vonzó imázsuk alakul ki (DÁVID - JANCSIK RÁTZ 2007).

\subsection{A kultúra szerepe a vidékgazdaság fejlődésében, a kultúragazdaság koncepciója}

Az utóbbi évtizedekben megerősödött a társadalomtudományokban az a szemlélet, amely a kultúrában gyökerező társadalmi tőkét gazdasági folyamatokat befolyásoló tényezőként azonosítják. A helyi kultúra (a tudás, az értékek, a hiedelmek és normák) gazdaság- és térségfejlesztő hatására hívta fel a figyelmet számos hazai és külföldi szerző (NÓGRÁDI 2010, MARINI - MOONEY 2006), sőt Bendixen a kultúrát a „gazdaság fejlődésének mozgatójaként” jelölte meg (BENDIXEN 2004). A helyi fejlesztések során átés újraértékelődik, és azokhoz igazodóan újjá konstruálódik a kulturális örökség, új szerepet kaphat a tradicionális gasztronómia és a helyi élelmiszerek, a helyi látványosságok és természeti értékek, épületek, szokások és hagyományok, felértékelődnek vidéki javak és szolgáltatások a rekreációban és a turizmusban (KOVÁCH 2010).

Ezen folyamatokhoz kapcsolódva a vidékfejlesztési politika lényegi tartalmát tekintve alapjaiban újszerü megközelítés honosodott meg, mely szerint a területi kiegyenlítés eszköze a helyi gazdasági, társadalmi és kulturális erőforrások kiaknázása. Ezt az új paradigmát fejtette ki és honosította meg Cristopher Ray 1998-ban, a Sociologia Ruralis folyóiratban publikált „kultúragazdaság” koncepciója. Ennek kulcsmegállapítása szerint Ray a helyi a kultúrát a vidéki térségek fejlesztésében alapvető fontosságúnak, fundamentumnak tekinti. Ezen, új alapokon nyugvó fejlesztési stratégia sikeres működéséhez három tényező együttes megléte szükséges. Egyrészt a fogyasztói és termelői magatartás átalakulása és összeegyeztethetősége, másrészt az állami és helyi fejlesztési 
stratégiák konszenzusa, harmadrészt pedig a regionalizmus. Ezekhez igazodóan Ray a kultúragazdaság négy, egymásra épülő fokozat-jellegü típusát különíti el (RAY 1998).

Az első típusban a már meglévő lokális kultúra, az adott helyhez köthető erőforrások „értékesítését” emeli ki a szerző. Ezek közvetlenül is piacra vihetők, de akár a térségmarketingben is könnyedén használhatók. A második típus új területi identitások és ehhez kapcsolódóan új termékek létrehozásáról szól, melyek értékesítése megtörténhet a külvilág felé (RAY 1998). A harmadik fokozatnál Ray szintén a kulturális erőforrások lokális identitást erősítő szerepét tartja alapvetőnek. Ez esetben azonban nem csak a térségen kívüli, hanem a térségen belüli szereplöket is meg lehet célozni (selling itself to itself) (RAY 1998). A negyedik típus az előző három sajátosságain alapul, de az önállóság magasabb fokát jelenti. Az adott térség saját belső erőforrásaira támaszkodva egy új, másoktól nem függő fejlesztési metódust dolgozhat ki magának (RAY 1998).

Ray tanulmányában rámutat arra is, hogy az általa kidolgozott kultúragazdaság koncepció nem csak a vidéki térségekre alkalmazható, hanem bármilyen térségtípusra is.

A kultúragazdaság elmélet leglényegesebb és a vidéki területek turizmusa szempontjából kiemelkedő vonása, hogy a helyben meglévő, lokális tudásra épít, annak újraértelmezésével teremt új lehetőségeket az adott térségben élők számára. 


\section{Az Alföld turizmusa}

Jelen fejezetben az Alföld turizmusát és vidékturizmusát elemzem annak mennyiségi és minőségi jellemzői alapján. Áttekintem a régió gazdag turisztikai vonzerőit, kiemelve azokat, amelyek legjellemzőbbek az Alföldre, jelentős a vendégvonzó képességük, továbbá néhány olyan tényezőt is, amely jelenleg még kisebb vendégforgalmat generál, de valamely szempontból speciális alföldi kínálati elemként a jövőben jelentőségük növekedhet.

Kvantitatív elemzéseim keretében az elérhető statisztikai adatokkal számszerüen is bemutatom az Alföld vendégforgalmát. E tekintetben azonban nagy nehézséget jelent, hogy a Központi Statisztikai Hivatal jelenlegi adatgyüjtési rendszerében rendelkezésre álló adatokkal erre legfeljebb közelítőleg van mód, ugyanis hivatalos statisztikai adatok csak a „Kereskedelmi szálláshelyek”, az „Üzleti célú egyéb szálláshelyek” (közte a „Falusi szálláshelyek”), valamint a „Nem üzleti célú közösségi, szabadidős szálláshelyek” vonatkozásában állnak rendelkezésre. Ezek okok miatt elemzéseim e kategóriák mentén, többségében az Alföld egészére vonatkoznak.

Számszerüsített mutatók mellett legalább ugyanolyan jelentőséggel bírnak a régió turizmusának azon kvalitatív mutatói, melyeket primer kutatásaim során igyekeztem feltárni, s az értekezés ezen részében összegezni a térség turizmusát működtető szakmai szereplők kérdőíves megkérdezése, valamint turisztikai szolgáltatásaik internetes megjelenéseinek elemzése alapján.

\subsection{A vidéki területek turizmusának története Magyarországon}

Az Osztrák-Magyar Monarchia idején kezdődő polgárosodás és gazdasági fejlődés nyomán a turizmus is kibontakozásnak indult. Számos mai is népszerü fürdőhely és klimatikus gyógyhely épült ki és vált népszerüvé már a dualizmus idején. Ekkortájt kezdődött el a Balaton turisztikai értelemben vett „felfedezése”, amely a tavakhoz, tópartokhoz kötődő utazások kiindulópontját jelentette.

A vidéki területekre irányuló turizmus hazánkban a két világháború között jelent meg először. Egyfajta mozgalommá, hazafias kötelességgé vált például a Trianon utáni időkben a belföldi vidéki üdülés, melynek kiteljesedését állami eszközökkel is támogatták. 1929-ben 
megalakult az Országos Magyar Weekend Egyesület (OMWE), mely 1936-tól Országos Magyar Vendégforgalmi Szövetség (OMVESZ) néven müködött tovább és segítette a belföldi üdülések szervezését. Mindezek mellett a vidéki hagyományok, kulturális értékek, így a néptánc, a népzene ápolására és bemutatására létrejött „Gyöngyösbokréta” mozgalom is nagyban hozzájárult vidéki területekre irányuló turizmus viszonylag gyors terjedéséhez.

Az állam úgy is az ügy mellé állt, hogy az OMWE díszelnökségét a kezdeti időkben maga Klebelsberg Kunó kultuszminiszter látta el. Az államigazgatáson belül is megindult a turizmust segítő intézményrendszer kiépülése. Először tíz megyében (Baranya, Borsod, Fejér, Heves, Nógrád, Pest Somogy, Veszprém, Zala, Esztergom) hoztak létre „megyei idegenforgalmi osztályintézőségeket”, majd 1934-től tovább bővült a hálózat Abaúj-Torna, Sopron Zemplén, Győr, Tolna, Csongrád és Hajdú megyékkel (KENÉZNÉ 1996).

Az OMWE kezdeményezésre elkészült a falun élő vendégfogadók számára a vendéglátás alapjait bemutató kiadvány, és kezdetét vette a mai értelemben vett szervezett „marketing tevékenység”. Ennek részét képezte a sajtó és a szakmai szervezetek folyamatos tájékoztatása, a kiállításokon való részvétel és a vidéken elérhető turisztikai szolgáltatásokat bemutató kiadványok (pl. „Utas könyve”) elkészítése az 1930-as évek közepén.

Jelentős lépés volt a turisztikai intézményrendszer további kiépülése szempontjából, hogy az állam a vármegyei és városi vendégforgalmi bizottságok, valamint a községfejlesztő bizottságok 1937-es létrehozásával a korábbinál erőteljesebb szerepet vállalt a feladatellátásban. Megjelent a „Vendégforgalmi újság”, sőt idegen nyelvü prospektusok is készültek (föleg németül) a külföldi vendégkörnek.

A hazai vidéki térségek gyors ütemben kedvelt turistacélponttá váltak, hiszen 1939-re több mint 250 településen regisztráltak vendégfogadást, és mintegy 70 ezer ember vette igénybe ezeket a szolgáltatásokat. Ekkor vált népszerü alföldi turistacélponttá a Hortobágy, valamint Bugac is. Ez utóbbi terület esetén a helyi elit összefogása és hathatós önszerveződő együttmüködése kellett a látványos sikerhez.

Már a két világháború között megkezdődött a hazai termál- és gyógyvízkészletek balneológiai célú kutatása és hasznosítása. Több napjainkban is ismert és látogatott alföldi fürdő (Hajdúszoboszló, Szeged, Berekfürdő) termálkútját ezidőtájt fúrták. Emellett a szénhidrogén-kutatások nyomán is számos településen termálvizet találtak (Cserkeszőlő, Hajdúböszörmény, Kecskemét, Kiskőrös, Mezőkövesd, Tótkomlós, Túrkeve) (LORBERER 2010), melyek hasznosítására később fürdők épültek.

A II. világháború után azonban minden megváltoztatott. Az államszocialista rendszer nem támogatta a vidéket, maradinak, a „szocialista fejlődés” akadályának tartotta. A 
mezőgazdaságot szovjet mintára kollektivizálták, a parasztságot termelőszövetkezetekbe kényszerítették. Néhány térségben, ahol a természeti adottságok és az azon alapuló tanyás gazdálkodási mód nem tette lehetővé a nagyparcellás, monokultúrás jellegü növénytermesztés meghonosítását, ott a kevésbé kötött formában müködő, a földet a gazdálkodók művelésében tartó szakszövetkezeteket hoztak létre (pl. Duna-Tisza-köze területe). A rendszer a vidéki térségekben történő üdülést általában nem ösztönözte, a korábbi intézmények megszüntek, a folyamatok - a gyógyvízre épülő vendégforgalom kivételével - megtörtek.

A 1970-80-as években a jövedelmek növekedésével azonban egyre szélesebb társadalmi rétegek számára váltak elérhetővé a szabadidős célú utazások, így hazánkban is megjelent a tömegturizmus, mely elsősorban a Balaton környékére és a mind kedveltebbé váló fürdőhelyekre összpontosult. Fontos azonban megemlíteni azt a tényt, hogy a szállodai kapacitások a jelentős fejlesztések ellenére is szűkösnek bizonyultak, és egyre inkább megnőtt az ún. „fizetővendéglátás” szerepe a szálláshely-kapacitáson belül. Az 1970-es évektől kezdődően kiépült egy olyan sajátos „,magánszálláshely” hálózat, amely alapvetően ellentétes volt ugyan a rendszer ideológiájával, de a szükös kapacitások pótlása céljából mégis megtürték. Mértékére jellemző, hogy a '70-es évekre ezen szálláshelyek aránya meghaladta az összkapacitás 50 \%-át (KOVÁCS 2015). Több utazási iroda (IBUSZ, Cooptourist, Express) saját fizetővendéglátó hálózatot épített ki. Jelentős változást hozott e szektor tekintetében is a rendszerváltáskor bekövetkező liberalizáció és a korábban kötelező nyilvántartás eltörlése, melyek nyomán a „szervezett magánszállásadás” szinte teljesen megszűnt. A korábbi és az új vendéglátók jelentős része az egyéni értékesítést választva az adómentességet élvező „falusi turizmus” nyilvántartási és adózási kategóriába lépett át (KOZIEL 2010). Néhány évvel később született csak meg az ágazat érdemi jogi szabályozása (110/1997-es kormányrendelet), mely a 2009-es új besorolás megalkotásáig rögzítette a fizetővendéglátás és falusi szállásadás kategóriákat. Részben az adatgyüjtés változása miatt a szektor számszerüsített mutatói jelentős csökkenést mutattak a rendszerváltás utáni 10 évben. Az 1990-es kiinduló adatokhoz képest a magánszállásadók és féröhelyek száma országos szinten kevesebb mint harmadára esett vissza. Az Alföldön még nagyobb arányú volt a csökkenés, ugyanis szállásadók száma alig ötödére, az igénybe vehető szállások száma pedig negyedére csökkent. Az Alföld országon belüli részesedése szintén csökkent mindkét mutató tekintetében 10 év alatt: a rendszerváltás idején jellemző 10\%-ot meghaladó arányról 6,4, illetve 7,1\%-ra. 
Az államszocialista rendszer lazulásával és a viszonylagos jóléttel összefüggésben jelentek meg hazánkban a második otthonok, melyek száma az 1970-es évektől folyamatosan emelkedett. A magánüdülők építésének legdinamikusabb szakasza az 19721988. között időszak, amikor minden évben több mint 3 ezer ilyen ingatlan épült az országban. A fö üdülőépítési területek a Balaton, a nagyobb tavak és folyóvizek mentén alakultak ki. A rendszerváltás után ugrásszerü csökkenés következett be, és a 2000-es években már csak alig több mint 1000 új magánüdülő létesült évente (CSORDÁS 2010).

\subsection{Falusi turizmus a rendszerváltást követően}

A „falusi turizmus” újbóli beindulása csak a rendszerváltás idején vált ismét lehetővé, jóllehet már az 1980-as évek elejétől egyre több terv jelent meg e tevékenység fejlesztése kapcsán. Ezek sorába tartozik a VÁTI által készített kutatás is, amely azt vizsgálta, hogy mely falvak lehetnek alkalmasak a falusi vendégfogadásra. 282 falu esetében javasolták a vizsgálatok alapján a turizmus beindítását, és 28-ra fejlesztési tervek is készültek. A turizmust akkoriban szervező intézmények, „vállalatok” tevékenységében viszont ez az üzletág erőteljesen marginális volt (KOVÁCS 2002), így ezek a tervek nem valósultak meg annyiban azonban mégis volt hasznuk, hogy ráirányították a szakma figyelmét a vidéki területekben rejlő potenciális turisztikai lehetőségekre.

A rendszerváltás erőteljes fordulópontot hozott az ország és a „,vidék” életében. A gazdasági depresszióból történő kiútkeresés során szinte minden település, a legkisebbek, a kevés vagy maximum helyi szintü attrakcióval rendelkezők is gyakran a „falusi turizmust” jelölték meg mint fö kitörési pontot, ettől remélték a település gazdaságának gyors fejlődését. Bebizonyosodott azonban, hogy ez önmagában nem csodaszer a problémák megoldására, sőt a kezdeti reményekhez képest igen kevés település számára hozott átütő erejü változást a helyi gazdaság diverzifikálásában, a vidéki jövedelemszerzési lehetőségek érezhető bővülésében.

A szervezeti keretek kialakulása már a rendszerváltáskor elkezdődött, ugyanis 1989ben magalakult a Magyar Falusi Vendégfogadók Szövetsége. Néhány évvel később, 1994ben pedig létrejött a Falusi Turizmus Országos Szövetsége, mely máig müködik. Szervezetét tekintve alulról építkező, a megyei tagszervezetekre támaszkodó, valódi szakmai szövetség, mely a tagság érdekképviselete mellett információnyújtással, a 
kutatások elvégzésével, a marketinggel segíti tagságát, és hosszú idő óta a hazai turisztikai szakma elismert szereplője.

A falusi turizmus jogi helyzete egészen 1997-98-ig rendezetlen volt. Ezt megelőzően nem volt jogszabály e tevékenység végzésére vonatkozóan, és a statisztikai adatgyüjtés is hiányzott, mondhatjuk ez volt a spontán fejlődés időszaka. A 110/1997-es Kormányrendelet, mely szabályozta a magánszállásadás és ezen belül a falusi szállásadás jogszabályi kereteit, valamint az ezzel kapcsolatos adatgyüjtés szabályait (110/1997. Kormányrendelet, 1997). Majd a 45/1998-as IKIM rendelet pedig a kereskedelmi és magánszálláshelyek minősítésére vonatkozó szabályokat határozta meg, a falusi szálláshelyeket pedig a magánszállások közé sorolta (45/1998. IKIM rendelet, 1998).

A rendeletek értelmében a „falusi magánszálláshelyek” közé tartozott minden „,idegenforgalmi célra hasznosított lakás, üdülő és egyéb épület (épületrész) a hozzájuk tartozó helyiségekkel és területekkel együtt”, amely „nem kiemelt gyógy-, kiemelt üdülő-, gyógy- vagy üdülöhelyeken kívül községekben és a már kialakult tanyás térségekben helyezkedik el" (45/1998. IKIM rendelet, 1998). A jogszabály meghatározta a maximális kapacitást (5 szoba, 10 ágy), valamint a falusi szálláshelyek típusait (vendégszoba; üdülőlakás, -lakrész; üdülőház (-tanya); sátorozóhely) és besorolta azokat komfortfokozat szerint is (összkomfortos, komfortos, félkomfortos, komfort nélküli szálláshely). A falusi szálláshelyek osztályba sorolására pedig a „napraforgós” minősítési rendszert vezette be. 24 napraforgós minősítést nyerhettek el a szállások attól függően, hogy:

- üdülésre és pihenésre alkalmas-e a település- és lakókörnyezet

- balesetet okozó körülményektől és környezeti ártalmaktól mentes-e a szálláshely

- milyen a szállás és környezetének esztétikai minősége, tisztasága

- milyen a szállásadó szakmai felkészültsége

- megoldott-e a hulladékgyüjtés és szállítás

- a szálláshely megfelel-e a komfortfokozatok technikai alapkövetelményeinek

- milyen a szálláshely egészségügyi helyiségeinek, konyhájának berendezettsége és felszereltsége

- a vendégszobák mérete és felszereltsége megfelel-e a minimális követelményeknek

- az egészségügyi helyiségek megfelelnek-e a komfortfokozat szerinti elöírások

- biztosított-e a konyha- és étkezőhasználat

- $\quad$ van-e pihenőkert és parkolási lehetőség. 
A rendelet egészen 2009. év végéig érvényben volt. Ekkor 239/2009-es Kormányrendelet értelmében jelentősen módosult (szükült) a falusi szálláshelyek statisztikai definíciója. A jogszabály csak az 5000 fő alatti lélekszámú, illetve 100 fö $/ \mathrm{km}^{2}$ alatti népsürüségü településeken lévő „egyéb” szálláshelyeket tekinti e kategóriába tartozónak. Ez különösen a ritka településhálózatú, egykori mezővárosias-kismezővárosias településszerkezeti jegyeket magán viselő Alföld nagyrégió esetén jelent szembetűnően nagy különbséget az adatgyüjtés megváltozása miatt. Megmaradt azonban a napraforgós minősítési rendszer, sőt 2011-től Nemzeti Tanúsító védjeggyé lépett elő.

Mint korábban is utaltam rá a vidéki területekhez kötődő turizmus pontosabb és teljesebb értelmezéséhez a jelenség statisztikai megközelítését is célszerü lenne hozzáigazítani. 


\subsection{Az Alföld turizmusa - a vonzerők alapján}

A fél országnyi kiterjedésű Alföld domborzatát tekintve síkvidék, mégis igen változatos természeti földrajzi adottságokkal bír, s a térség több évszázadra visszatekintő kulturális öröksége is sokszínü és egyedi (ld. Fotómelléklet). A továbbiakban ezek mentén mutatom be az Alföldre leginkább jellemző turisztikai vonzerőket és az azokra alapozott turisztikai termékeket.

A turisztikai szakirodalom mindazon tényezőket vonzerőnek tekinti, amelyek „kiváltják a turisták érdeklődését és utazásra ösztönzik őket” (RÁTZ 2011). Két nagy csoportjuk különíthető el: a természet- és az ember alkotta vonzerők.

\subsubsection{Természet alkotta vonzerök}

A természeti környezet elemei közül az Alföld nagyrégió vonatkozásában megkülönböztetett jelentősége van a termál- és gyógyvizeknek, melyekben az Alföld sajátos földtani viszonyainak köszönhetően kiemelkedően gazdag. A geotermikus gradiens e térségben a világátlagnál másfélszer magasabb országos értéket is meghaladja, így nem véletlen, hogy a hazai mintegy 1000 termálkút zöme itt található. Ugyanígy a 236 hazai gyógyvízkút közel felét, 107 alföldi településen fúrták. A térség kiváló hidrogeológiai adottságaira több mint 80 fürdő települt, s az Országos Egészségbiztosítási Pénztárral szerződött 171 magyar gyógyfürdőből 64 db helyezkedik el az Alföldön. Ezek közül 10 településen 11 alföldi intézmény rendelkezik a 2014 óta elnyerhető „Fürdők Nemzeti Tanúsító Védjegye" minősítéssel, ami az országosan minősített 21 fürdő több mint fele. Hét térségbeli település (Gyula, Debrecen, Hajdúszoboszló, Nyíregyháza-Sóstógyógyfürdő, Mezőkövesd, Kismunmajsa és Orosháza-Gyopárosfürdő) pedig a „gyógyhely” minősítést is elnyerte.

A termál-és gyógyvizekhez kapcsolódó egészségturisztikai szolgáltatások 11 alföldi gyógyszállodában vehetők igénybe, melyek közül 7 rendelkezik a Magyar Szállodák és Éttermek Szövetsége által működtetett Hotelstars Union - Nemzeti Szállodai Tanúsító Védjegy szerinti minősítéssel. A 31 alföldi wellness hotel fele mutathat fel ilyen tanúsítványt.

Az alföldi gyógy- és termálvizek, valamint a fürdők vonzerejének kiemelkedő jelentőségét jelzi, hogy az ezen adottságokkal rendelkező településeken az országos átlagot 
szignifikánsan meghaladó mértékü a szállásférőhelyek és a turisták által eltöltött vendégéjszakák aránya. Míg 2014-es adatok szerint országos szinten a kereskedelmi szállásférőhelyek 56\%-a, az egyéb szálláshelyeknek pedig $41 \%$-a, az összes vendégéjszakának pedig 74\%-a realizálódott fürdővel rendelkező településeken, addig ezen adatok az Alföldön sorrendben közel 71\%, illetve több mint 78\%, a vendégéjszakák esetén pedig 93\% feletti. Nyilvánvalóan más vonzerők is lehetnek az érintett településeken vagy közvetlen környezetükben, de arra mindenképpen markánsan utal ez a magas arány, hogy meghatározó az Alföldön a gyógy- és termálvizekhez kötődő turizmus.

\section{8. ábra: Fürdőtelepülések és vendégéjszakák az Alföldön (2014)}

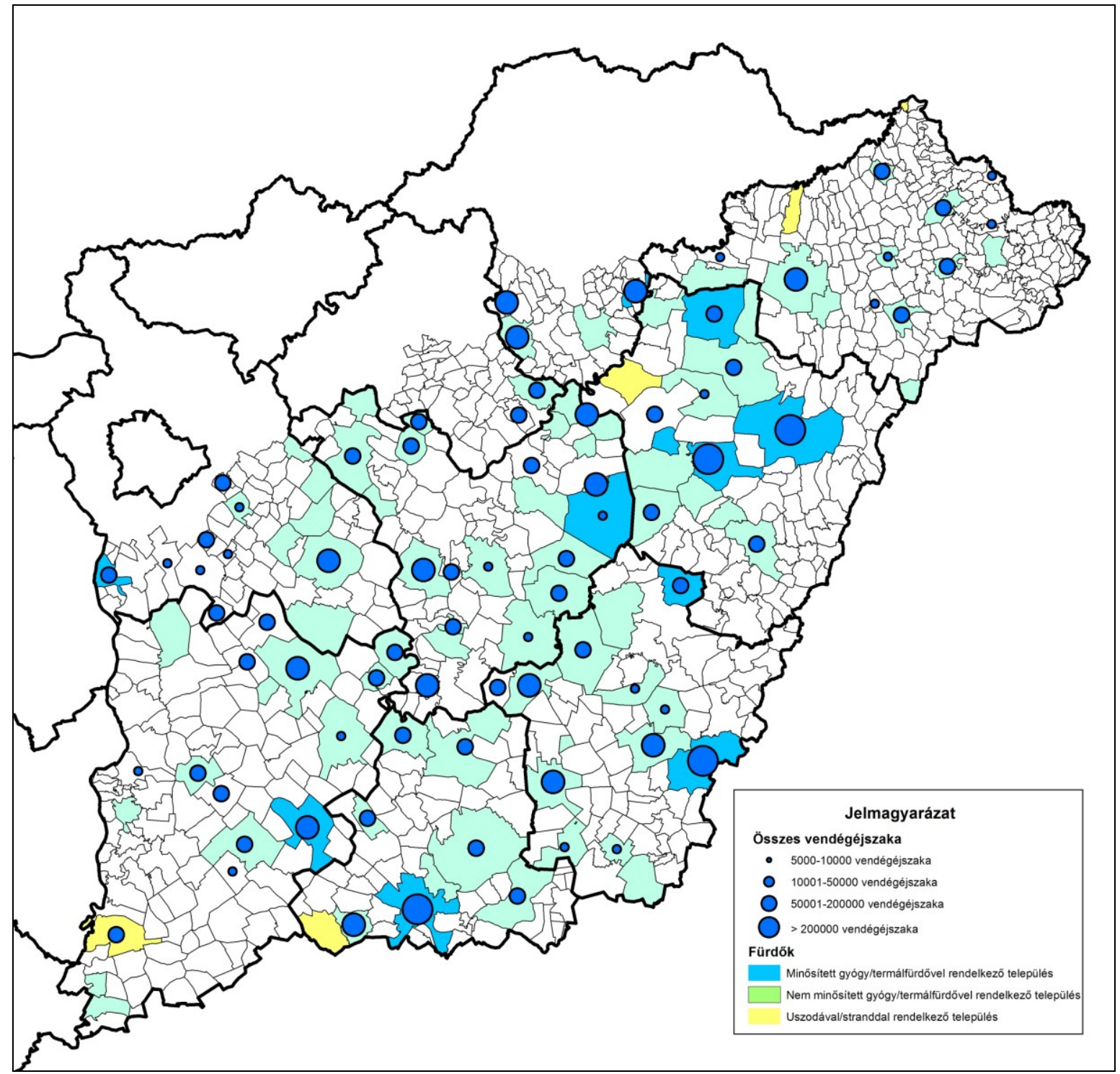

Forrás: KSH, Magyar Turizmus ZRt. NETA, saját szerkesztés

A felszíni vizeket tekintve szintén kitünőek a térség adottságai. Az Alföldön oly jellemző folyók, tavak, holtágak egyaránt turisztikai vonzerőt jelentenek. A folyók a XIX. 
századi folyószabályozásokig a legfőbb felszínformáló erőként alakították a táj arculatát, s meghatározóak voltak a térség gazdasági életére. A Kárpát-medence domborzati és hidrogeográfiai viszonyaiból adódóan révén óriási vízmennyiség haladt és halad át a térségen. Hazánk legnagyobb folyói közül a Duna, a Tisza, a Körösök, a Maros és a Szamos egyaránt érintik, illetve átszelik az Alföld vidékét, és esetenként meghatározzák annak hidrogeográfiai-hidrológiai, klimatikus viszonyait, továbbá jelentősen befolyásolják a terület gazdasági életét.

Kiváló színterei korunkban a vízi sportoknak, a vízitúrázásnak, a vízparti üdüléseknek, a strandolásnak és a horgászatnak. A szervezett vízitúrák közül külön ki kell emelni a Tisza túrát, mely a folyó felső szakaszán kerül megrendezésre évről évre, valamint a Körösök Völgye Határtalan Vándortúrát, mely a Fekete-Körös romániai forrásától indulva egészen a Kettős-Körösig (Békésig) tart. A vízi turizmushoz kapcsolódó megállóhelyek egységes minősítésére hozták létre a „Lapátos vízi megállóhely” Nemzeti Tanúsító Védjegyet, mellyel kapcsolatban az operatív teendőket a Magyar Kajak-Kenu Szövetség látja el. Infrastrukturális ellátottságuktól függően 1-4 lapátos minősítést nyerhetnek el a vízi megállóhelyek. Az országosan minősített 72 állomás közül 35 található az Alföldön (20 db a Tisza, $11 \mathrm{db}$ a Körösök és $4 \mathrm{db}$ a Duna mentén).

A felszíni vizekhez kötődő legtöbb turisztikai vonzerővel és attrakcióval a Tisza-tó rendelkezik. Itt a legkiépültebb a vízi turizmus és a horgászat infrastrukturális háttere, és az infrastruktúra alapelemét jelentő kikötőhálózat is e térségben a legsűrübb. A 12 Tisza-menti kikötőből 7 található a Tisza-tavi régióban. Szabadvízi strandjai (Tiszanána, Sarud, Tiszafüred, Poroszló, Abádszalók, Kisköre) már az 1980-as évektől kedvelt turistacélpontok.

A folyók mentén lévő további szabadstrandok közül különleges, egyedi vonzerőt képez homokfövenyes partszakaszával a Vásárosnamény-Gergelyiugornyai és a Csongrád Körös-toroki strand, illetve kedvelt üdülő- és kirándulóhely Békés megyében a Fehér- és Fekete-Körös összefolyásánál Szanazug.

Az Alföld tavai keletkezésüket tekintve igen változatosak. A morotvatavakon (Szelidi-tó) át, a szikes tavakig (Kun-Fehér-tó) egészen a szél vájta tavakig (Sós-tó) számos típus megtalálható a térségben, és a nyári szezonban nagy tömegek számára jelent vonzerőt. A folyószabályozások nyomán keletkezett holtágak szintén egyedi vonzerőt jelentenek. Jelentőségüket mi sem jelzi jobban, mint hogy a Duna és a Tisza völgyéhez kapcsolódóan több mint $250 \mathrm{db} 5$ hektárnál nagyobb felületủ holtágat tartanak nyilván, s legnagyobbjuk, a 
Szarvas és Békésszentandrás környékén lévő Körös-holtág rendszer Magyarország ötödik legnagyobb állóvize.

Jóllehet az Alföld ma már jórészt emberkéz által formált kultúrtájnak tekinthető, azonban bizonyos részein mégis sokkal kevésbé érték antropogén hatások, mint számos, főleg nyugat-európai tájat. A természeti környezet ugyan sok esetben mozaikszerűen, de számos területen eredeti vagy ahhoz közeli állapotában megmaradt hazánk e nagy kiterjedésű síkvidéki területén. Jelzésértékű az Alföld természeti értékeire vonatkozóan, hogy itt alapították Magyarország első nemzeti parkjait, a Hortobágyi Nemzeti Parkot 1973-ban, a Kiskunsági Nemzeti Parkot pedig 1975-ben. Ugyancsak az alföldi élővilág és táj védelmére szervezték meg 1997-ben a Körös-Maros Nemzeti Parkot. További két Nemzeti Park (Bükki NP és a Duna-Dráva NP) területének egy része érinti pedig az Alföld általam vizsgált járásait. Ezen felül 11 Tájvédelmi Körzet és 52 Természetvédelmi Terület is található e vidéken.

Kiemelkedő a turizmus szempontjából az Alföldön található négy nemzeti parki látogatóközpont. A Hortobágyi Nemzeti Park Hortobágyon, a Körös-Maros Nemzeti Park Szarvason és Dévaványa-Réhelyen, a Kiskunsági Nemzeti Park pedig Kecskeméten működteti ezen modern, interaktív bemutatóelemekkel ellátott objektumait, ahol a látogatók a Tiszántúl, illetve a Duna-Tisza-köze védett értékeinek esszenciáját tekinthetik meg az érdeklődők, továbbá szakvezetéseken és terepi foglalkozásokon vehetnek részt. Speciális színfoltját képezi a természeti értékek bemutatóhelyeinek a Poroszlón létesített Tisza-tavi Ökocentrum, mely az 1970-es években mesterségesen létrehozott Tisza-tó, valamint annak táplálója, a Tisza, a „legalföldibb” folyó élővilágának megismertetése révén kínál egyedülálló élményt.

A természeti-táji-kultúrtörténeti értékek megőrzése és bemutatása, a környezeti nevelés elősegítése, valamint a fenntartható turisztikai és rekreációs hasznosítás érdekében jöttek létre Magyarországon a natúrparkok. Turisztikai szempontból lényeges szerepük van a müködési területükön lévő attrakciók turisztikai termékké formálásában, a tájhoz illeszkedő tematikus túrák és helyi programok (pl. ökoturisztikai programok és helyi termék vásárok) szervezésében és kommunikációjában, valamint föleg a nagyvárosok közelében lévőek esetén rekreációs funkciójuk sem elhanyagolható.

Jelenleg hazánkban 9 térség viselheti hivatalosan is ezt a címet, és további 6 terület szerezheti meg azt a közeljövőben a természetvédelemért felelős minisztériumtól. Az Alföld területén jelenleg a Szatmár- Beregi és a Körösök Völgye Natúrpark rendelkezik állami elismertséggel. Az előbbi több mint 103 ezer $\mathrm{km}^{2}$ kiterjedésű és 67 települést foglal 
magába, míg az utóbbi 207 ezer $\mathrm{km}^{2}$-t meghaladó összterületével (14 település) a legnagyobb kiterjedésủ valamennyi közül. Gyulától Kunszentmártonig egybefüggő területet képez a Körösök mentén.

\section{9. ábra: Nemzeti Parkok és Natúrparkok Magyarországon}

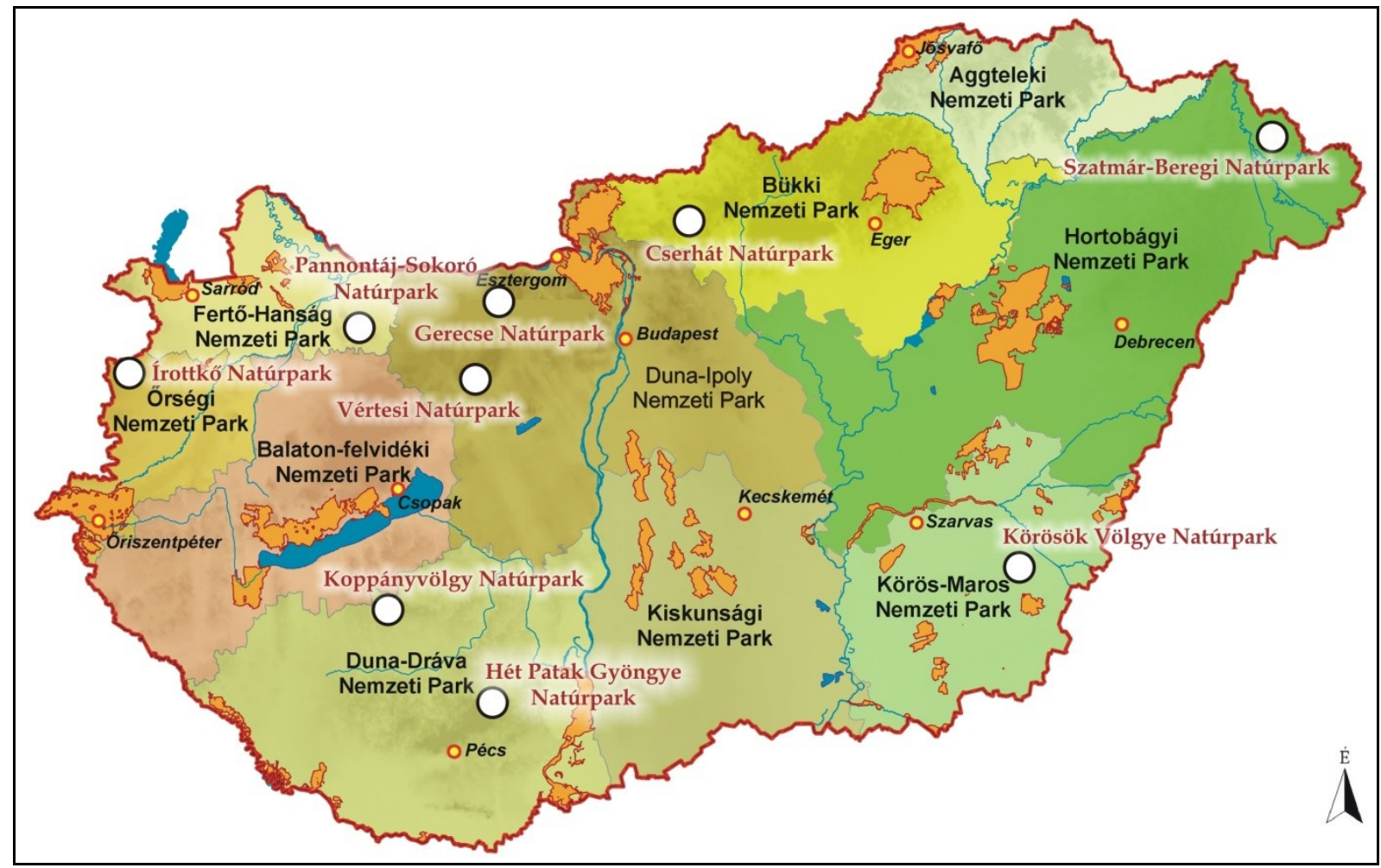

Forrás: Magyarországi Natúrparkok Fejlesztési Koncepciója, 2016.

A természet és az ember harmonikus alföldi együttélésének máig szinte eredeti valójában érintetlenül megmaradt színtere, egyben az UNESCO világörökség része, Európa legnagyobb füves pusztája, a Hortobágy, illetve a Hortobágyi Nemzeti Park. Természetitermészetvédelmi értékei mellett Alföld kulturális örökségének is kiemelkedő eleme.

\subsubsection{Ember alkotta vonzerök}

A magyarság kulturális örökségének kiemelkedő helyszíne, egyben a magyar államiság egyik bölcsője, az Ópusztaszeri Nemzeti Történeti Emlékpark. Anonymus „Gesta Hungarorum” címü müve szerint a magyarok vezérei itt „ejtették szerét” az ország dolgainak, itt jött létre a magyar állam első kezdeménye. Ma itt látható Feszty Árpád „Magyarok bejövetele” címü, az ország milleniumi ünnepségeire készült körképe, az 
egykoron virágzó „Szer Monostorának” maradványai, valamint a Dél-alföldi népi építészet számos emléke is egy skanzenben.

Az Alföld történelmének viharos évszázadai épített örökségében is tükröződnek. A tatárjárás és főleg a török hódoltság következtében szinte teljesen elnéptelenedett a térség, az addigi településhálózat jó része megsemmisült. Csak a XVII-XVIII. századtól indult meg a terület újbóli benépesülése, és a mai településhálózat kialakulása. A mai „történelmi városok", valamint az épített örökség elemei jórészt ekkortól datálhatók és erőteljes vidékies gyökerekkel rendelkeznek. Kevés azonban a történelem korábbi viharait átvészelő műemlék. Egyike ezeknek az 500 éves Szeged-Alsóvárosi Ferences Kolostor, ahol ma már látogatóközpont fogadja a vendégeket. A török korban fontos védelmi funkciót látott el a Gyulai Vár, mely az egyetlen épen maradt alföldi gótikus téglavár Európában. Az Alföld másik máig fennmaradt téglavára Kisvárdán található. Nyaranta mindkét helyszínen várszínház színesíti a vonzerők palettáját.

Az alföldi nagyvárosok (Debrecen, Szeged, Kecskemét, Nyíregyháza) tárgyiasult és szellemi öröksége is erőteljes ,vidékies” gyökerekkel rendelkezik, hiszen a mai városok az egykori alföldi mezővárosokból fejlődtek ki, s magukon viselik annak bizonyos településmorfológiai, építészeti jegyeit, hajdani kiterjedt tanyavilágukhoz való kapcsolatukat, valamint a hagyományokban és identitásban megnyilvánuló sajátosságait is. Ezek és a modernitás együttes megjelenése jelentik ma egyedi vonzerejüket. Szeged esetében a nagy árvíz utáni újjáépítés hozott sajátos európai építészeti világot.

Különös, az Alföldön sehol máshol nem jellemző építészeti értéket és vonzerőt képvisel az 1200 pincéből álló hajósi pincefalu, ahol mai is működő löszbe vájt pincék és présházak mutatják be az ide telepített svábok szőlőtermesztéshez és bor előállításhoz kapcsolódó hagyományait. A népi építészet és az egykori tradícionális alföldi életmód (halászat) harmonikus együttélését tükrözi a máig fennmaradt Csongrád városi ősi településmag, a Belsőváros. A 37 megmaradt „halászház” ma részben vendégfogadóként szolgál és műemléki védettséget élvez.

A népi kultúra megőrzését szolgálják és ezáltal kiemelkedő jelentőségü a magyar Tájház hálózat, amely éppen napjainkban kandidál az UNESCO világörökségi címre. Az Alföldön 41 településén található tájházak kiemelkedő szerepet töltenek be a vidéki területek népi építészetének, tárgyi kultúrájának, szellemi örökségének és hagyományainak megőrzésében és ápolásában.

Az Alföld vallási képének jellegzetessége a sokszínűség mellett a protestantizmus erőteljes jelenléte, különösen a Tiszántúlon. A történelmi egyházak közül a római katolikus 
(domináns a Kiskunságban, Jászságban és Szeged környékén), a görög katolikus (jellemzően az Alföld ÉK-i részén), a református (domináns a Tiszántúlon) és az evangélikus (főleg Békés megyében) is jelen van a térségben. Valamennyi felekezethez köthetők turisztikai szempontból fontos vonzerők. A római katolikushoz Kalocsa, mint ezer éves érseki székhely és Szeged, mint püspöki székhely egyházi épületei és gyüjteményei; a Mária út alföldi szakasza, valamint az alföldi Mária kegyhelyek. A görög katolikushoz Máriapócs, mint nemzeti kegyhely kapcsolódik. A reformátushoz Debrecen, a „kálvinista Róma” egyházi és oktatási épületei, valamint Szabolcs-Szatmár-Bereg megyében 130 müemlék református templom, amire a Középkori Templomok Útja c. program is épül. Az evangélikushoz Békéscsaba és Szarvas szakrális épületei tartoznak.

A vallási turizmus és a zarándoklatok ma már világszerte az egyik legtöbb turistát vonzó szegmense az ágazatnak. Vonzerői, mint látható az Alföldön is potenciálisan adottak, azonban a jelenleginél számottevőbb turisztikai alágazattá csak a zarándokútvonalak kijelölésével és a kapcsolódó szolgáltatási rendszer (pl. szálláshelyek, éttermek, stb.) lényeges bővítésével válhatnak.

Mára az Alföld turisztikai kínálatának fontos részévé váltak fesztiválok és rendezvények. Ma már szinte alig találunk olyan települést, ahol ne rendeznének olyan helyi eseményt, amely egy-egy helyi termékhez, személyhez vagy szokáshoz kötődik. Elnevezésükre gyakran használják a „fesztivál” kategóriát, amely így egy kissé túl általánossá vált, s igazából a legalább térségi vagy még inkább a regionális/országos jelentőségü rendezvények esetén lenne célszerü csak azt valójában alkalmazni ${ }^{7}$. Így a kifejezés egy minőségi kategóriát is jelölhetne. Minden bizonnyal ez a törekvés jelentette a fő mozgatórugót a Magyar Fesztiválszövetség számára is, amikor megalkotta a Magyar Fesztivál Regisztrációs és Minősítő Programot. Ennek első részeként valamennyi magát fesztiválnak tekintő rendezvény kérheti regisztrációját, majd második körben a regisztrációt elnyerő fesztiválok vehetnek részt a minősítési folyamatban. A 2015. év végéig regisztrált 43 alföldi fesztivál között 12 gasztronómiai, 27 kulturális és 4 egyéb rendezvényt találhattunk. Ezek zömmel a legnagyobb, legismertebb alföldi rendezvények, mint a Csabai Kolbászfesztivál, Debreceni Virágkarnevál, Gyulai Végvári Napok, Szegedi Szabadtéri Játékok, Szentesi Lecsófesztivál. Minősítést 15 fesztivál kért az országban, ebből 6 alföldi rendezvény.

\footnotetext{
${ }^{7}$ A helyi jelentőségü rendezvények, falunapok is fontos szerepet töltenek be a helyi közösségek életében, a helyi identitás erősítésében különösen ha egy vagy több helyi értékhez (élelmiszer, néphagyomány) kötődnek.
} 
A Magyar Turizmus Zrt. Nemzeti Turisztikai Adatbázisa (NETA) összegzi a turisztikai jelentőséggel bíró rendezvényeket. 2015. év végén 200-at meghaladó alföldi rendezvényt tartalmazott, melynek több mint fele $(123 \mathrm{db})$ a Dél-Alföldön valósul meg. Jellegüket tekintve jól érzékelhetően dominálnak a kulturális és a gasztronómiai rendezvények.

3. táblázat: Rendezvények típusai az Alföldön

\begin{tabular}{|l|c|c|c|c|}
\hline & Gasztronómiai & Kulturális & Sport & Egyéb \\
\hline $\begin{array}{l}\text { Észak-alföldi } \\
\text { régió }\end{array}$ & 30 & 26 & 6 & 19 \\
\hline Dél-alföldi régió & 30 & 45 & 16 & 32 \\
\hline $\begin{array}{l}\text { Egyéb alföldi } \\
\text { területek }\end{array}$ & 9 & 7 & 0 & 8 \\
\hline Összesen & 69 & 78 & 22 & 59 \\
\hline
\end{tabular}

Forrás: Magyar Turizmus Zrt. NETA ( www.itthon.hu ) (2015. december)

Vannak közöttük több évtizedes múltra visszatekintő események (pl. Szegedi Szabadtéri Játékok, Hírös Hét Fesztivál, Debreceni Virágkarnevál), egy részük viszont az elmúlt 20 évben indult útjára. A sok évtizedes tradíció önmagában nem jelent szignifikáns kapcsolatot a jelentőségükkel, hiszen pl. a „csak” 20. alkalommal megrendezésre kerülő Csabai Kolbászfesztivál mára az Alföld egyik legnagyobb és legjelesebb, nemzetközi jelentőségű gasztronómiai rendezvényévé vált.

A fesztiválok és rendezvények között többségben vannak a nagy- és középvárosokban zajló, főleg kulturális tematikájú események. Szép számmal találhatunk olyan rendezvényeket is, amelyek más jellegü (pl. gyógyfürdő) vonzerökkel bíró, nagy turistaforgalmú településeken zajlanak mintegy színesítve azok kínálatát (Hajdúszoboszló, Gyula). Jellemzőek a nagyvárosban megrendezésre kerülő, de a környék termékeit középpontba állító rendezvények is. Ezek a „város és vidéke” turisztikai szempontból is értelmezhető együttélésére, kapcsolatára utalnak. Ilyen pl. Kecskemét esetén a Helyi termék ünnep, a Garabó napok, a Barackpálinka és Borfesztivál).

A falvakban kevésbé jellemzőek a helyi és térségi lakosság érdeklődésén túlmutató, érdemi turisztikai vonzerővel bíró rendezvények. A kivételek közé tartozik a szatmár-beregi térség, ahol a széles körben ismert helyi termékekhez, nem mostanában kreált, hanem évszázados kultúrához és hagyományokhoz köthető, a vidék valós értékeit bemutató rendezvények kerülnek megszervezésre kis településeken is (Nemzetközi Molnártalálkozó 
- Túristvándi, Nemzetközi Szilvalekvárfőző Verseny - Szatmárcseke, Szatmár-Beregi Szilvanapok - Az Új pálinka ünnepe - Tarpa). Nagyon eröteljes és az Alföld más pusztai területein nem jellemző ennyire egyértelmủen, mint Hortobágy településen a rendezvények pásztorkodó életmódhoz köthető tematikája (Hortobágyi Hídi Vásár - Országos Kirakodóés Népművészeti Vásár, Hortobágyi Pásztorok és Magyar Hagyományőrző Pásztorkutyások Találkozója, Országos Gulyásverseny és Pásztortalálkozó). A kisvárosok közül Mórahalom példája emelhető ki, ahol a rendezvények tematikáját egyre inkább a helyi hagyományokhoz és gasztronómiai értékekhez alakítják (Szent György napi kihajtás, Rétesfesztivál, Pálinka- és Tepertőfesztivál).

A gasztronómia egyértelmüen karakterisztikus eleme az Alföld turisztikai kínálatának. Nem véletlenül, hiszen a táj kiváló mezőgazdasági adottságai nyomán e térség az ország legjelentősebb mezőgazdasági termőkörzete, s ez megjelenik a köztudatban is az „ország éléskamrája” metafora révén. Mi sem jelzi jobban a térség jelentőségét az élelmiszer előállításban, minthogy innen eredeztethető az elismert 20 agrárélelmiszergazdasági hungarikum nagy többsége, szám szerint 14. A „Hagyományok - Ízek - Régiók” (HÍR) - Magyarországi hagyományos és tájjellegü mezőgazdasági és élelmiszeripari termékek gyüjteményében ugyancsak erőteljesen van jelen az Alföld. A 2010 óta pályázati úton HÍR védjegyoltalmat nyert 56 pályázó fele (ld. 2. sz. melléklet), a 126 védjegyes termék közel fele $(59 \mathrm{db})$ alföldi illetőségü, és további 4 pályázó ugyan nem alföldi székhelyü, de $8 \mathrm{db}$ jellegzetes alföldi termékre nyerte el a védjegyet.

Manapság a fogyasztói igényekhez igazodóan egyre elterjedtebbek a helyi termelői piacok, ahol az adott megyében vagy a piac 40 km-es körzetében előállított mezőgazdasági, illetve élelmiszeripari termékeiket értékesítik a kistermelők. Ezeken mód nyílik nem csak a helyi lakosság számára, hanem a térségbe érkező turisták számára is a helyi termékek beszerzésére. A Nemzeti Agrárgazdasági Kamara nyilvántartása szerint 80 termelői piac működik az alföldi településeken. A legtöbb Csongrád (29 db), Békés (14 db) és SzabolcsSzatmár-Bereg megyében (13 db). Ezek számottevő szerepet játszanak a területre érkező vendégek élelmezésében is.

Egyre fontosabb szempont a fogyasztók számára az ellenőrzött alapanyagokból, ökológiai gazdálkodásból származó élelmiszer-alapanyagok és termékek fogyasztása. A hagyományos alföldi gasztronómiai kínálatban is megjelent már ezen új irányzat. A legautentikusabb helyen, a Hortobágyi Csárdában a Hortobágyi Nemzeti Parkban nevelt szürke marhából, bivalyból, mangalica sertésből, rackajuhból, gyöngytyúkból és halból 
készült, kizárólag bio minősítésü ételspecialitások szerepelnek az étlapon. Sőt Hajdúszoboszlón immár több mint 10 éve Bioétel- és Borfesztivált is rendeznek.

A hazánkban nyilvántartott 22 borvidék közül a Duna Borrégiót alkotó 3 bortermő körzet található az Alföldön ${ }^{8}$, jellemzően a Duna-Tisza-közén: a Csongrádi, a Hajós-Bajai és a Kunsági. Ez utóbbi a legnagyobb területi kiterjedésű a hazai borvidékek között.

A homokos, illetve helyenként löszös talajoknak és a napsütéses órák magas számának köszönhetően a három alföldi borvidéken könnyed, gyümölcsös ízekkel teli borok teremnek, melyek a maguk kategóriájában egyre kedveltebbek a borfogyasztók körében. Azonban a korábbi évtizedek mennyiséget a minőség rovására előtérbe helyező termelési szemlélete, valamint a térséghez köthető borhamisítási ügyek jelentősen rombolták az alföldi borok megítélését és hírnevét. Az utóbbi másfél évtizedben kibontakozott azonban egy, a minőségi bortermelést előtérbe helyező szemlélet, $\mathrm{s}$ fokozatosan egyes alföldi borok is bekerültek az elismerten magas minőségü hazai nedük közé. Maga a borász szakma is elismerte ezt a folyamatot, hiszen a kunsági borvidékről Frittmann János (2007-ben) és Gálné Dingisz Éva (2013-ban) is elnyerte az „Év bortermelője,, rangos szakmai elismerést.

A legjelentősebb borászatokat, kulturális és hagyományőrző tevékenységet folytató magánszemélyeket és vállalkozásokat, önkormányzatokat tömörítő, 2002-ben létrejött Duna Borrégió Borút Egyesület deklaráltan a minőségi bortermelés előmozdítását, a borturizmus fejlesztését és a térséget behálózó borutak kialakítását tüzte ki célul. A szolgáltatások egységes minőségi kategóriáinak kialakítására és besorolására létrehozták a „Borúti Karta” alapelvein nyugvó minősítési rendszert, amely alapján az egyes borászatok ,3-5 poharas” minősítést kaphatnak. A borrégió területén hat borút került kialakításra, amelyek rendre érintik a térség utóbbi évtizedben épült kiváló borházait is, három borvidék legjelesebb borászatait kapcsolják össze. Jóllehet a közeli szekszárdi vagy a villányi borvidék borútjainak ismertégéhez és látogatottságához nem mérhető jelentőségük, de az Alföld vidékturisztikai vonzerőinek ígéretes és növekvő potenciált magában rejtő terméke a borturizmus.

\footnotetext{
${ }^{8}$ Az Alföld északi peremén a Bükki borvidék is érinti általam vizsgált 70 alföldi járás közül a mezökövesdit.
} 
10. ábra: Borutak a Duna Borrégióban

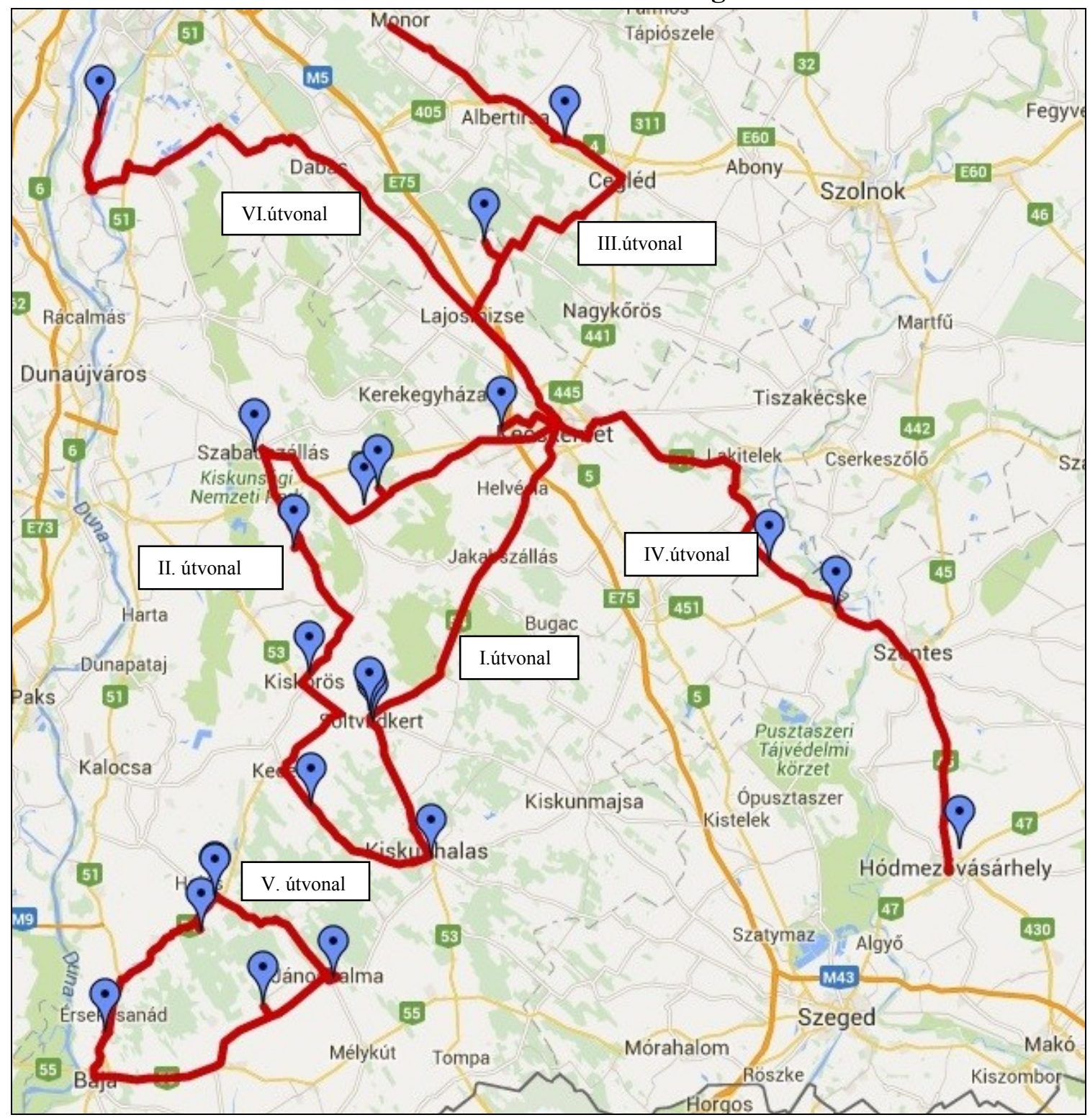

Forrás: Duna Borrégió Borút Egyesület

A természeti adottságok, a hagyományok és a kultúra együttesen teremti meg a lovaglás és a lovas turizmus alapjait az Alföldön. A természeti adottságok közül a síkvidéki terep, a nagy bejárható terek kiváló feltételeket kínálnak a lovaglásra. A ló évszázadokon át a magyar ember mindennapjainak nélkülözhetetlen részéhez tartozott. Egyrészt igaerő, másrészt a vasút és a személygépkocsik megjelenéséig alapvető közlekedési „eszköz” is volt a lóvontatta szekér és postakocsi.

A rendszerváltást követően újra reneszánszát éli a hobbi célú lótartás, gombamód szaporodtak és szaporodnak a lovas egyesületek. Annak ellenére történik mindez, hogy igen költséges tevékenységről van szó. A lovas turizmus már az 1980-as évektől ígéretes fejlődésnek indult a kedvező adottságú helyeken, ám egészen napjainkig nem érte el közel 
sem azt a szintet, amelyre az adottságok predesztinálnák. Aktív (pl. lovas túrák, fogathajtás) és passzív (pl. lovas bemutatók) formái egyaránt megtalálhatók a kínálati palettán.

A lovas tanyák térbeli elhelyezkedése igen speciális képet mutat. A Dél-Alföld 3 megyéjében sokkal inkább jellemző a lovas szolgáltatók jelenléte, mint az Alföld más részein. A Magyar Kereskedelmi Engedélyezési Hivatal 2012-es nyilvántartása szerint 100ból 57 db lovas szolgáltató telephelye a Dél-Alföldön helyezkedett el. Térbeli megjelenésük másik speciális vonása, hogy csaknem egyharmaduk (32 db) az alföldi nagyvárosok szuburbán jellegü járásaiban (kecskeméti, szegedi, békéscsabai, nyíregyházi) müködött, ami egyértelmü összefüggést mutat az ottani magasabb jövedelmü fogyasztói kör meglétével. Vendégkörük általában vegyes: nem csak a turisták, hanem a legtöbb esetben a helyi vagy környékbeli lakosság is igénybe veszi szolgáltatásaikat. Turisztikai szerepük e két tényező egymáshoz viszonyított arányától függően változó. Leginkább a nagyobb települések, főleg a városok kínálatához kapcspolódva komplementer turisztikai termékként jelennek meg.

\section{1. ábra: A lovas szolgáltatók és a vendégéjszakák száma az alföldi járásokban (2012)}

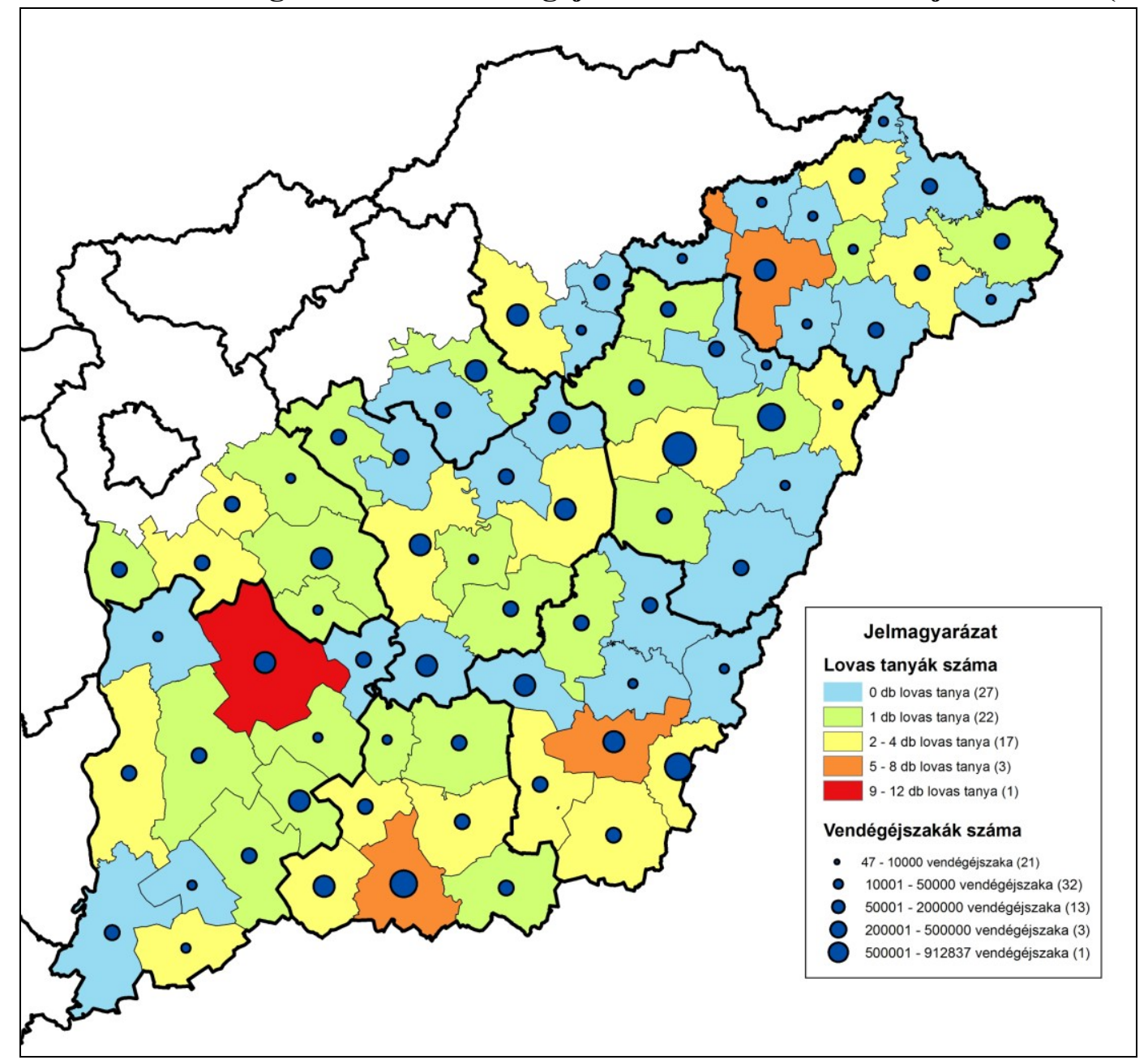

Forrás: TeIR, saját szerkesztés 
A szektor szereplőinek jó részét tömörítő Magyar Lovas Turisztikai Közhasznú Szövetség (MLTSZ) minősítési rendszert dolgozott ki a lovas bázisok besorolására. Hasonlóan a borturizmushoz vagy a falusi szálláshelyek napraforgós minősítéséhez, ötfokozatú minősítést (1-5 patkós) szerezhetnek meg a lovas tanyák, szolgáltatásaik minőségétől függően. Az MLTSZ 2015. évi nyilvántartása szerint 290 tagjuk volt szerte az országban, ebből az Alföldön 114 db. Országos és nagyrégiós szinten is több mint 80\%-uk rendelkezett patkós minősítéssel, nagy többségük jellemzően 3 patkós. Megfigyelhető a magas minőségi kategóriák dominanciája, ugyanis mindkét területi szinten a minősítettek több mint $85 \%$-a a 3 vagy több patkós kategóriákba tartozottk. Mindezek ellenére a szolgáltatások további fejlesztése, köztük a kijelölt lovas túra útvonalak létrehozása elengedhetetlen feltétele az egyik „legalföldiesebb” kínálati elem, a lovas turizmus valódi lehetőségeinek hasznosításához. 


\subsection{Az Alföld turizmusának föbb statisztikai adatai}

\subsubsection{A kereskedelmi és egyéb szálláshelyek adatai}

Az Alföld turizmusának mennyiségi mutatók mentén történő vizsgálata a hivatalos statisztikai adatgyüjtésben meglévő adatok alapján végezhető el. A Központi Statisztikai Hivatal havonta gyüjti és publikálja a kereskedelmi szálláshelyek, és évente az egyéb (2009-ig „magán”) szálláshelyek vendégforgalmi adatait. Ezen mutatók településsorosan legyüjthetők, azonban adatvédelmi okok miatt a KSH csak olyan településen tesz közzé vendégforgalmi adatokat, ahol legalább három szálláshely szolgáltató müködik. Ez jelentős adatvesztést okozhat a szálláshelyek vendégforgalmi statisztikájában, hiszen sok kistelepülésen jellemző, hogy háromnál kevesebb vendégfogadó müködik az adott helyhatóság területén.

Az Alföld turizmusának mennyiségi jellemzőire vonatkozó elemzéseimet általában járási szinten végeztem. Ennek oka az volt, hogy ezen területi szinten már kellő mennyiségben és komplexitásban mérhetők a vonzerők, speciális indoka pedig, hogy a nagyrégió településszerkezetének sajátosságai és turizmusának jellemzői alapján ez a területi szint szolgál talán a szignifikánsabb információkkal (s ezen a szinten már nem jelentős az adatvesztés a KSH rendszerében). Ahol persze a folyamatok megértése megkívánta és segítette azt a település szintü elemzés, ott ezen adatokat is felhasználtam.

Ha a turizmusban érintett települések számát vizsgáljuk, akkor viszonylag erős térbeli szóródás figyelhető meg az elmúlt 15 éves időszakban. A kereskedelmi és egyéb (2009-ig magán) szálláshelyeken vendégéjszakákat regisztráló települések köre jelentősen bővült. Míg 1999-ben 247 településen mért a KSH egyáltalán vendégéjszakákat, addig 2014-ben már 321-en. Ez a települések számát tekintve több mint $9 \%$ pontos bővülést jelent. Az újonnan belépő települések jellemzően 10 ezer fö alatti vidéki falvak és kisvárosok jórészt alacsony vendégforgalommal, amit visszaigazol, hogy vendégéjszakáik száma a 2014. évi összesített alföldi adat mindössze 2,3\%-át teszi ki. Kettősség jellemezte tehát a szóródást: Az érintett települések számát tekintve erőteljes, a vendégéjszakák vonatkozásában pedig szerény mértékü bővülés volt tapasztalható. A települések térbeli eloszlása kiegyenlítettnek tekinthető, Szatmár és Bereg térségében, a Tisza-tó környékén, Békés megyében, Szeged környékén, valamint Pest és Bács-Kiskun megye Duna-menti területeihez igazodóan rajzolódnak ki térbeli sűrüsödések. 
Az Alföld településeinek mintegy 6\%-ában, 47 településen szünt meg 1999-2014. között a vendégfogadás és nem realizálódott vendégéjszaka. Főleg Jász-Nagykun-Szolnok, Pest és Bács-Kiskun megyében találhatók ezen falvak és városok, de néhány eset SzabolcsSzatmár-Bereg megyében is regisztrálható.

A turizmusba még be nem kapcsolódott települések az Alföld valamennyi megyéjében fellelhetők. Jelentős térbeli sủrüsödésük a kevesebb vonzerővel rendelkező térségekben figyelhető meg Szabolcs-Szatmár-Bereg megye középső harmadában, továbbá Hajdú-Bihar megye dél-keleti és Békés megye észak-keleti határ menti területein, illetve Bácskában.

\section{2. ábra: A turizmusban érintett települések az Alföldön}

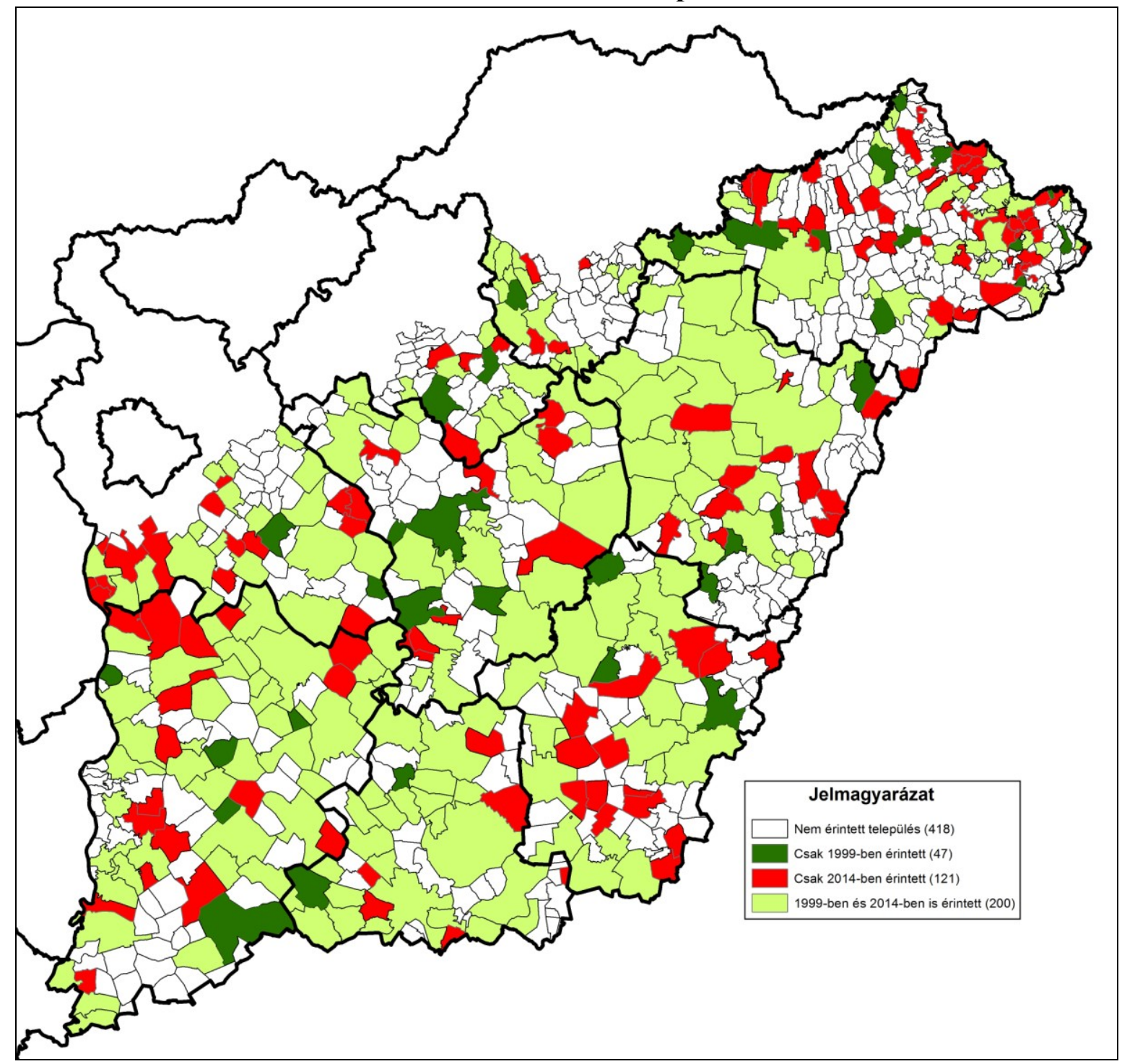

Forrás: KSH TSTAR, saját szerkesztés

A turisztikai fogadóképesség jellemző mennyiségi mutatója a szálláshelyek kapacitása. Az Alföld vonatkozásában a vizsgált 1999-2014. közötti időszakban jelentős 
mértékben, mintegy 60\%-kal nőtt a szálláshelyek száma, s a szállásférőhelyek száma is közel 45\%-kal emelkedett. Az összes magyarországi szálláshely között az alföldiek aránya így 9,1\%-ról 16,1\%-ra, a szállásférőhelyeket tekintve pedig 16,9\%-ról 18,3\%-ra nőtt 15 év alatt. E jelentős mennyiségi növekedésben erőteljes szerepet játszottak az igénybe vehető EU-s szálláshely fejlesztési támogatások pozitív és olykor negatív értelemben egyaránt. A megvalósult projektek jó része valóban hiányzó kapacitásokat pótolt, de a pályázati rendszer anomáliái miatt akadtak olyanok is, amelyek inkább presztízsberuházások voltak, inkább a forráslehívást célozták, semmint a valós és indokolt szálláshely hiányt orvosolták.

4. táblázat: Szálláshelyek száma az Alföldön

\begin{tabular}{|l|r|r|r|r|}
\hline & \multicolumn{1}{|c|}{$\mathbf{1 9 9 9}$} & \multicolumn{1}{|c|}{$\mathbf{2 0 0 4 .}$} & \multicolumn{1}{c|}{$\mathbf{2 0 0 9}$} & \multicolumn{1}{c|}{$\mathbf{2 0 1 4 .}$} \\
\hline $\begin{array}{l}\text { Egyéb (2009-ig magán) szállásadók } \\
\text { száma }\end{array}$ & 3151 & 4719 & 5586 & 5340 \\
\hline Falusi szállásadók száma & 995 & 1815 & 1938 & 673 \\
\hline Kereskedelmi szálláshelyek száma & 696 & 769 & 787 & 827 \\
\hline Szállásadók száma összesen $^{9}$ & 3847 & 5488 & 6373 & 6167 \\
\hline
\end{tabular}

Forrás: KSH TSTAR, saját számítás

5. táblázat: Szállásférőhelyek száma az Alföldön

\begin{tabular}{|c|c|c|c|c|}
\hline & 1999. & 2004. & 2009. & 2014 \\
\hline $\begin{array}{l}\text { Egyéb (2009-ig magán) szállásadók } \\
\text { száma }\end{array}$ & 18159 & 30224 & 38887 & 38299 \\
\hline $\begin{array}{lll}\text { Falusi } & \text { szállások } & \text { féröhelyeinek } \\
\text { száma } & & \\
\end{array}$ & 5930 & 12022 & 13146 & 5100 \\
\hline $\begin{array}{ll}\text { Kereskedelmi } & \text { szálláshelyek } \\
\text { férőhelyeinek száma } & \end{array}$ & 64391 & 75556 & 75168 & 80914 \\
\hline $\begin{array}{ll}\text { Szállásférőhelyek } & \text { száma } \\
\text { összesen } & \end{array}$ & 84409 & 105780 & 114055 & 119213 \\
\hline
\end{tabular}

Forrás: KSH TSTAR, saját számítás

A szálláshelyek minőségét tekintve is jelentős elmozdulás történt a magasabb minőségi kategóriák felé. Mi sem jelzi ezt jobban, minthogy 15 év alatt megháromszorozódott és mára meghaladta a 30 -at a $4 *$-os szállodák száma, és a falusi szálláshelyek közül pedig több mint 400 rendelkezik ma már napraforgós Nemzeti Tanúsító Védjegy szerinti minősítéssel.

\footnotetext{
${ }^{9}$ Az egyéb, illetve 2009-ig magán szálláshelyek és a kereskedelmi szálláshelyek száma összesen.

${ }^{10}$ Az egyéb, illetve 2009-ig magán szállások és a kereskedelmi szállások férőhelyeinek száma összesen.
} 
Összességében mind az egyéb (2009-ig magán), mind a kereskedelmi szálláshely egységek száma, illetve féröhelyeinek száma nőtt 1999 és 2014. között. Az egyéb szállásadáson belül nyilvántartott falusi szállásadók és féröhelyek száma viszont 2009-ig emelkedett, majd a rájuk vonatkozó nyilvántartási jogszabályok 2010-től érvényes változásával egyidejűleg nagy mértékben csökkent. A szálláshelyek számát tekintve 25,9\%ról 10,9\%-ra, a férőhelyek vonatkozásában pedig 7\%-ról 4,2\%-ra esett vissza arányuk.

A kapacitások térben meglehetősen egyenlőtlenül helyezkednek el és nagy szóródást mutatnak. Az alföldi járások adatai az ötven féröhely alattitól egészen a 17 ezret meghaladó értékig szóródnak. Átlag alatti férőhely számmal általában a határ menti, periférikus fekvésű járások bírnak, míg azt meghaladó értékekkel kevés kivételtől eltekintve a térség nagyvárosait (Debrecen, Nyíregyháza, Szeged, Kecskemét, Szolnok) és fürdőhelyeit (Hajdúszoboszló, Gyula, Berekfürdő, Cserkeszőlő, Mórahalom, Kiskunmajsa) magukban foglaló, illetve a Tisza-tó környékén fekvő járások, valamint egyes tipikusan vidékies turisztikai szolgáltatásokat kínáló térségek (fehérgyarmati és vásárosnaményi) rendelkeznek. Sajátos tény, hogy a járások többségében a kereskedelmi szállásféröhelyek dominálnak, ezért sem lehet ezen szállástípust figyelmen kívül hagyni a vidékturizmus vizsgálatánál. Az „egyéb” szálláshelyek kapacitása a legnagyobb fürdőket magukban foglaló járásokban, a Tisza-tó környékén és Szatmár-Beregben haladja meg a kereskedelmi szálláshelyekét.

Ugyancsak egy sajátos vonása a térség turizmusának a kapacitás kihasználtságban lévő nagy különbségek. Ez még a turisztikailag frekventált desztinációk esetén is érvényes. Legjellemzőbb példaként említhető a hajdúszoboszlói és a szegedi járás, ahol a kereskedelmi szálláshelyek kapacitása nagyságrendileg azonos, ám az előbbi több mint két és félszer több vendégéjszakát tudhat magáénak. A hajdúszoboszlói járás turizmusa közismerten a gyógy-és termálvizekre épül, emiatt hosszabb a vendégek átlagos tartózkodási ideje, jobb a kapacitás kihasználtság. Szeged és járása esetén pedig erősebbek a kulturális vonzerők, valamint nagy az átutazó forgalom is az átlagos tartózkodási idő és a kapacitás-kihasználtság alacsonyabb szintjét eredményezi. 


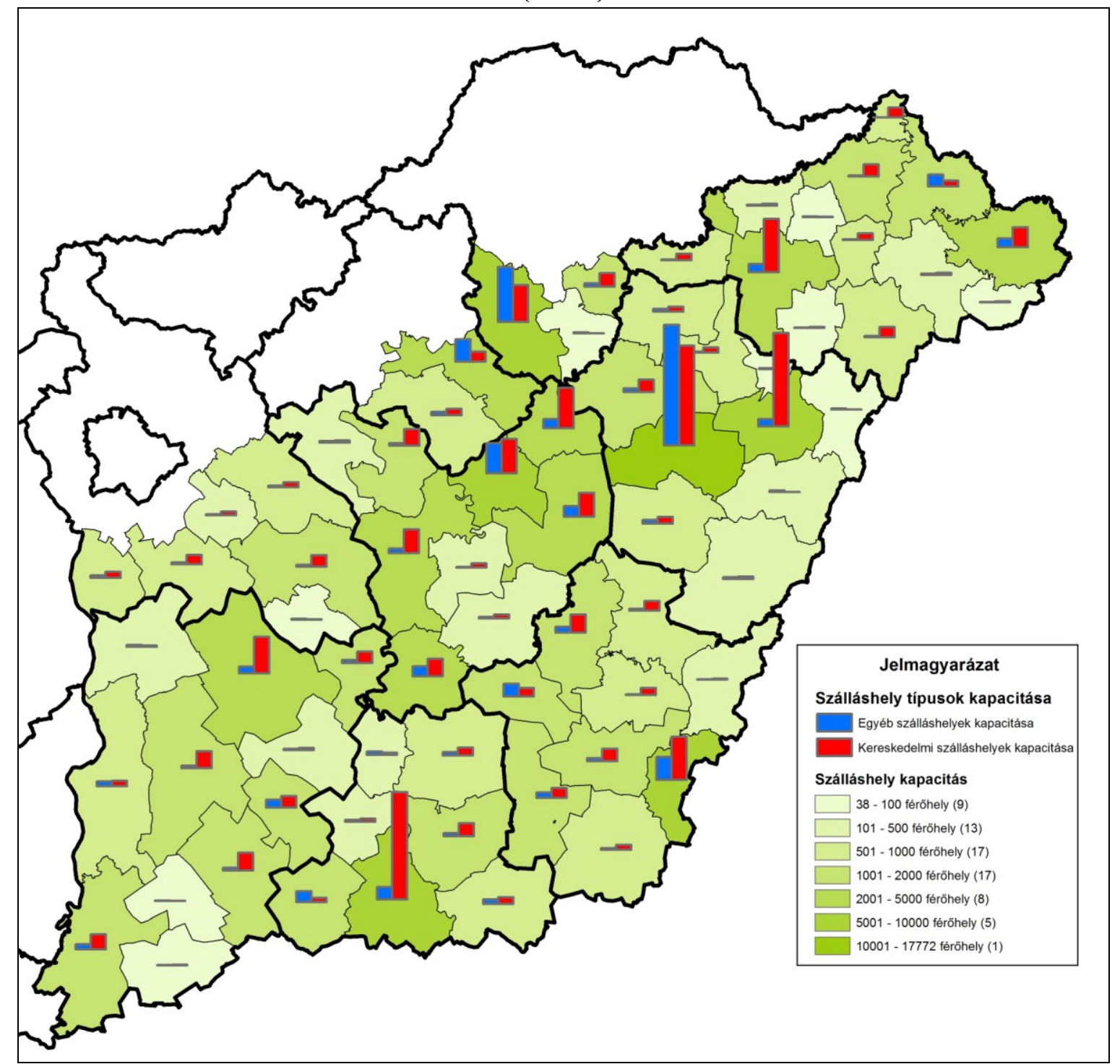

Forrás: KSH TSTAR, saját szerkesztés

A gyakorlatban is hasznosítható információkkal szolgálhat a szálláshely kapacitási adatok települési szintű vizsgálata. Egy-egy település turisztikai fogadóképessége szempontjából sokat elárul, hogy el lehet-e ott szállásolni egy kisbusznyi (20 fö), illetve egy normál méretü autóbusznyi (45 fö) vendéget. A KSH adatai szerint az alföldi települések közel felében (46\%) egyetlen szállásférőhely sem volt 2014-ben, így statisztika által mérhető turistaforgalom sem keletkezhetett. További több, mint ötödükben van $20 \mathrm{db}$ vagy az alatti számú férőhely, azaz az előző kategóriával együtt a települések 2/3-ában nem lehetett egyszerre egy kisbusznyi embert elszállásolni. Alig több mint 22\%-uk alkalmas arra, hogy egy normál autóbusz utasainak egyszerre szállást adjon. Kevéssel 15\% feletti azon települések aránya, ahol már két autóbusznyi vendég szállásolható el egyszerre. A 
települési szintü fogadókapacitás térbeli eloszlását mutatja az alábbi ábra, mely alapján jól érzékelhető az alföldi térség keleti, észak-keleti részeinek alacsony szálláskapacitása.

\section{4. ábra: Kereskedelmi és egyéb szálláshelyek kapacitása az Alföldi településeken}

\section{(2014.)}

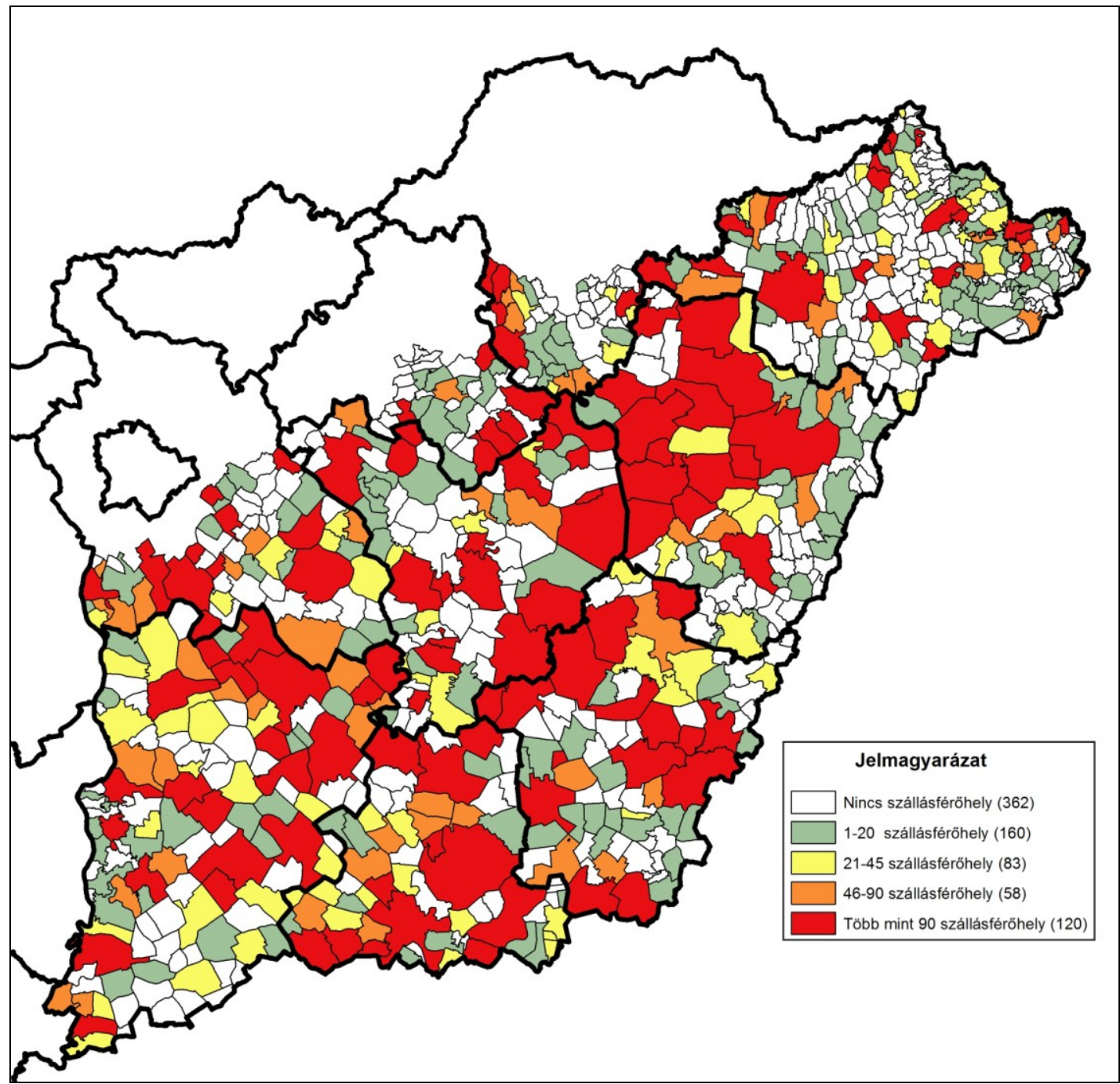

Forrás: KSH TSTAR, saját szerkesztés

Az Alföld turizmusának a vendégek és vendégéjszakák száma alapján mért összteljesítménye az országos adatok növekedési ütemét meghaladó mértékben emelkedett 1999-2014. között. Országosan az elöbbi mutató több mint 77\%-kal, az utóbbi ettől jelentősen elmaradva, 35,5\%-kal emelkedett. Ettől dinamikusabb növekedést ért el az Alföld, ahol majdnem megduplázódott a vendégszám (+92,6\%) és több mint 50\%-kal nőt a vendégéjszakák száma ugyanezen időszakban. Ezek nyomán némileg nőtt a térség országon belüli súlya (1,3\% ponttal, illetve közel $2 \%$ ponttal), de még mindig $20 \%$ alatt van mindkét mutató vonatkozásában. Mivel a Budapesten kívüli térségek növekedése az országos és az alföldi átlagnál is alacsonyabb volt, így az Alföld részesedése a „vidéki Magyarországon” 
belül növekedett: a vendégszámot tekintve 21,4\%-ról 25,4\%-ra, a vendégéjszakák esetében pedig 18,6\%-ról 24,25\%-ra. A vendégek átlagos tartózkodási ideje valamennyi területegységnél csökkent: legkisebb mértékben, 14\%-kal az Alföld esetén, 20\%-kal országos szinten, 24\%-kal a Budapesten kívüli térségekben. Ez nyilván az Alföld régió gyógyturizmusa miatt van.

A teljesítménymutatók közül legkifejezőbb vendégéjszakák száma. Ez az Alföld vizsgált 70 járásában 15 év alatt 53,6\%-kal emelkedett, ami leginkább azért figyelemre méltó, mert 8 százalékponttal meghaladja a szállásféröhelyek korábban bemutatott növekedését. Ebben minden bizonnyal nagy szerepet játszott az üdülési csekk bevezetése és használatának elterjedése, valamint az Alföldet érintő egészségturizmus népszerűvé válása.

A vendégéjszakák időbeli alakulását áttekintve a növekvő trendet két hullámvölgy töri meg: 2004 és 2005., valamint 2009-2013. közötti. Ez utóbbi a gazdasági-pénzügyi válság hatásaként jelentkezett, s mélypontján a válság előtti utolsó évhez képest $12 \%$-ot meghaladó csökkenést eredményezett.

15. ábra: A vendégéjszakák számának alakulása az Alföldön

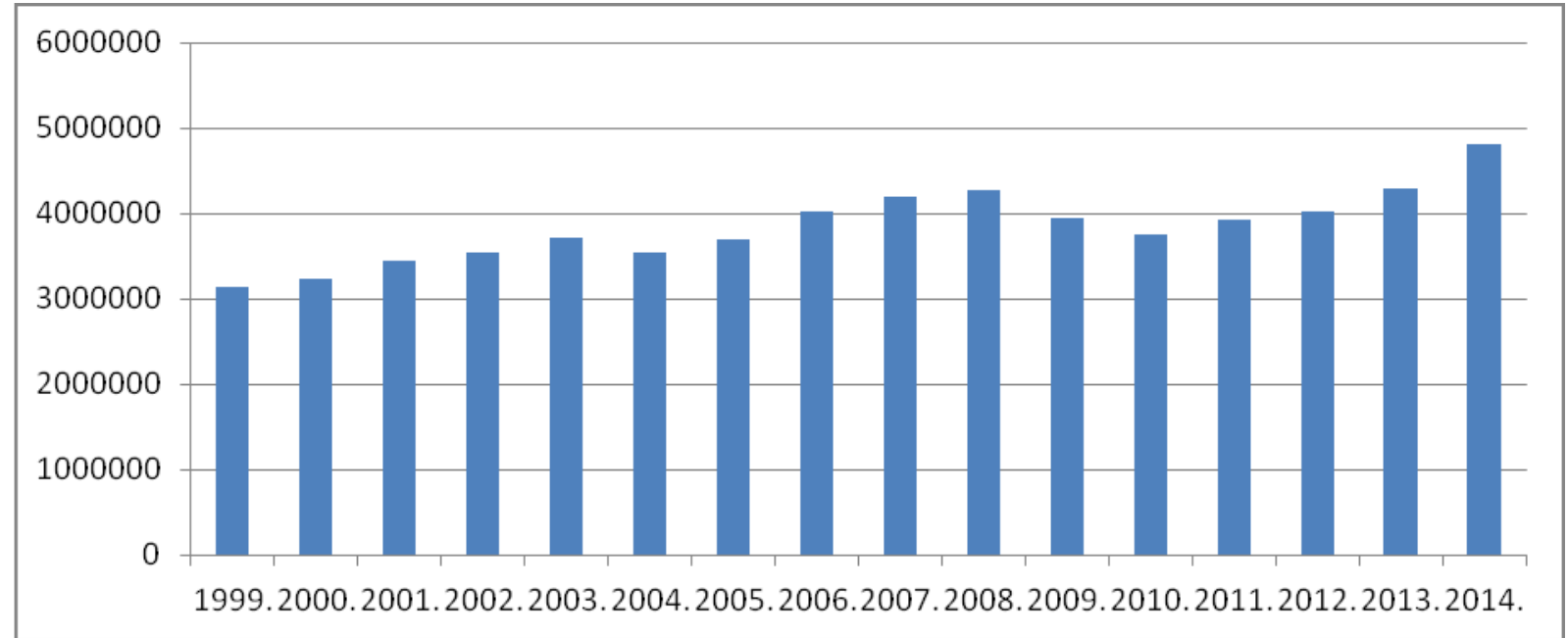

Forrás: KSH TSTAR, saját számítás

Az alföldi vendégéjszakák szállástípusok közötti megoszlásában kisebb átstrukturálódás történt a vizsgált 15 éves időszakban. A kereskedelmi szálláshelyek végig dominánsak voltak, és részesedésük ugyan csökkent a vizsgált időszak végére, de így is 80\% feletti. Az egyéb (korábban magán) szálláshelyek viszont ezzel párhuzamosan lassú, de folyamatos emelkedést mutattak. Ugyanígy nőtt 2009-ig a falusi szállásokon eltöltött vendégéjszakák aránya, 2010-től azonban javarészt a fogalmi besorolás változása miatt egyre inkább visszaesett részesedésük, s 2014-re alig haladta meg a 1,5\%-ot. 
6. táblázat: Vendégéjszakák aránya szállástípusonként az Alföldön

\begin{tabular}{|c|c|c|c|c|c|c|c|c|}
\hline & 1999. & $\%$ & 2004. & $\%$ & 2009. & $\%$ & 2014. & $\%$ \\
\hline $\begin{array}{l}\text { Egyéb (2009-ig magán) } \\
\text { szállások vendégéjszakái }\end{array}$ & 431241 & $13,75 \%$ & 540656 & $15,3 \%$ & 736515 & $18,6 \%$ & 829251 & $17,2 \%$ \\
\hline $\begin{array}{ll}\text { Falusi } & \text { szállások } \\
\text { vendégéjszakái } & \end{array}$ & 95497 & $3,05 \%$ & 148624 & $4,2 \%$ & 199138 & $5 \%$ & 77438 & $1,6 \%$ \\
\hline $\begin{array}{l}\text { Kereskedelmi } \\
\text { szálláshelyek } \\
\text { vendégéjszakái }\end{array}$ & 2704264 & $86,25 \%$ & 3001710 & $84,7 \%$ & 3213074 & $81,4 \%$ & 3985943 & $82,8 \%$ \\
\hline Összes vendégéjszaka & 3135505 & $100 \%$ & 3542366 & $100 \%$ & 3949589 & $100 \%$ & 4815194 & $100 \%$ \\
\hline
\end{tabular}

Forrás: KSH TSTAR, saját számítás

Rendkívül nagy a forgalom települési koncentrációja, hiszen a TOP 20 (azaz az első húsz) alföldi település ${ }^{12}$ több mint 3 millió 580 ezer eltöltött vendégéjszakával a teljes vendégforgalom több mint 3/4-ét reprezentálja. A TOP 10 település is az összes vendégéjszaka több mint 58\%-át adja. Járási szinten vizsgálva is hasonlóan erős a koncentráció, hiszen a hajdúszoboszlói járás egymagában több mint 21\%-át képviseli az összes alföldi vendégéjszakának. A további négy 200 ezer feletti vendégéjszakával rendelkező járással (debreceni, gyulai, mezőkövesdi, szegedi) együtt az alföldi érték közel felét (48,97\%-át) teszik ki. A három legvárosiasabb járás (debreceni, szegedi, nyíregyházi) a teljes alföldi vendégforgalom 18\%-át adja. Az ellentétes végletet az a 13 járás adja, ahol a vendégéjszakák száma egyenként 5000 alatt marad. Ezek többnyire attrakciókkal kevésébé rendelkező, határ menti, periférikus térségek (csengeri, záhonyi, nyíradonyi, derecskei, sarkadi, bácsalmási, jánoshalmi járás).

A járások 2014-es vendégéjszaka adatai rendkívül széles skálán mozognak. A kétszázat alig meghaladó és az 1 millió 35 ezres érték között szóródnak az adatok. Ezek, mint turisztikai teljesítmények persze akkor igazán összehasonlíthatóak, ha az 1000 lakosra jutó vendégéjszakák számát vesszük górcső alá. Messze az átlag alatti mutatóval rendelkezik a magyar-román határ menti, periférikus járások jó része, Duna-menti járások közül a kalocsai és a kunszentmiklósi, továbbá a nagykőrösi, az ibrányi és a kemecsei. Átlagos értékkel bír több karakteresen vidékies turisztikai attrakciókkal rendelkező járás (fehérgyarmati, vásárosnaményi, balmazújvárosi, püspökladányi). A nagyvárosok, megyeszékhelyek járásai jóllehet erőteljes centrumai turizmusnak magas

\footnotetext{
${ }^{11}$ Magán (2009-től egyéb), valamint a kereskedelmi szálláshelyek vendégéjszakái összesen.

${ }^{12}$ TOP 20 település csökkenő sorrendben: Hajdúszoboszló, Gyula, Debrecen, Szeged, Nyíregyháza, Cserkeszőlö, Kecskemét, Mezőkövesd, Bogács, Berekfürdő, Szolnok, Kiskunmajsa, Cegléd, Tiszafüred, Mórahalom, Orosháza, Békéscsaba, Tiszaújváros, Szarvas, Ráckeve
} 
népességszámuknak köszönhetően - a fajlagos mutatókról lévén szó - nem kerültek a legmagasabb értékkel bíró kategóriába. Szinte kivétel nélkül oda tartoznak viszont az országos és nemzetközi vonzerővel bíró fürdőhelyek járásai (mezőkövesdi, hajdúszoboszlói, gyulai, karcagi, kunszentmártoni, mórahalmi, kiskunmajsai), illetve a Tisza-tó menti területek egy része (tiszafüredi, füzesabonyi járás).

\section{6. ábra: 1000 lakosra jutó vendégéjszakák az alföldi járásokban (2014)}

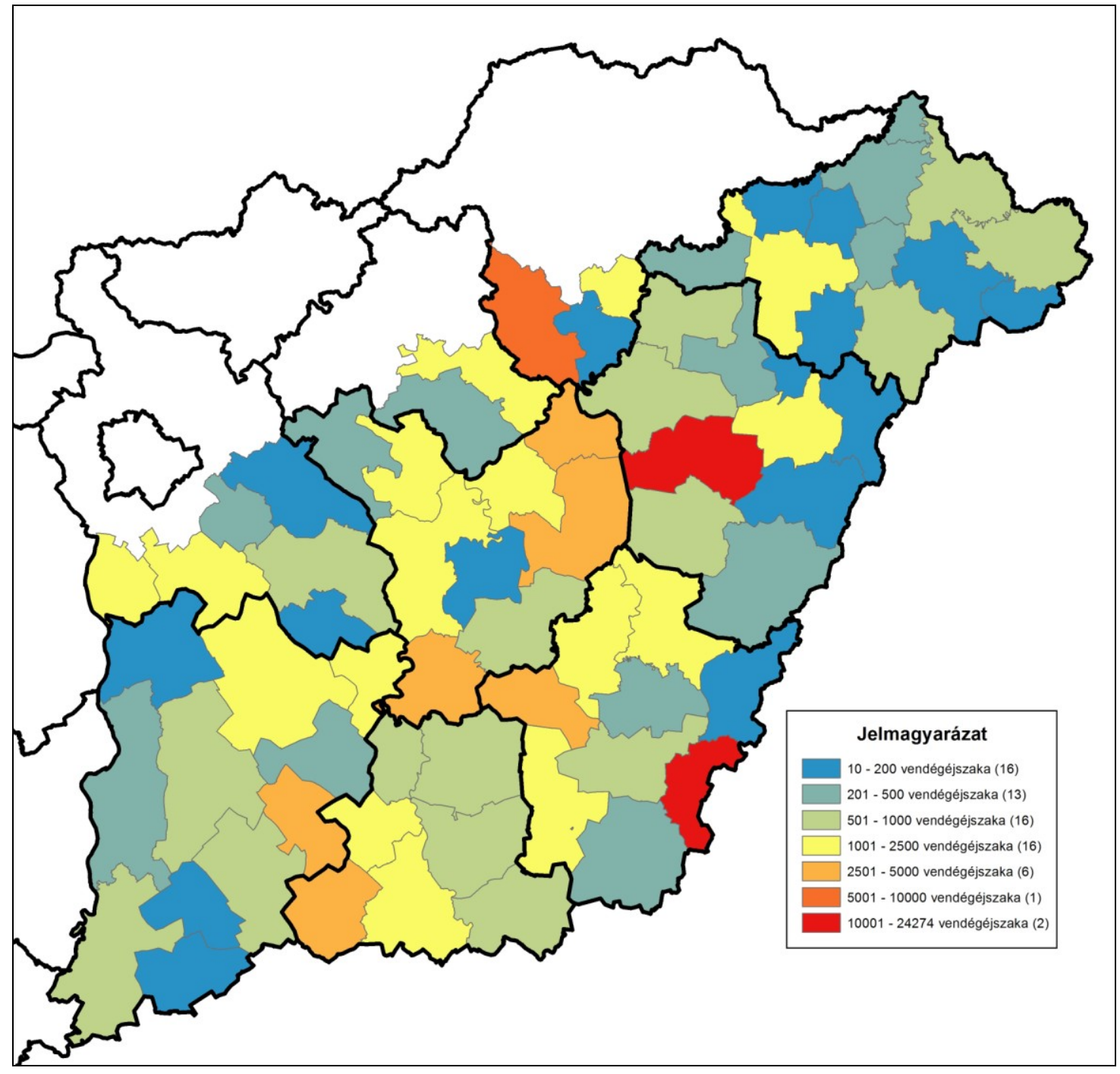

Forrás: KSH TSTAR, saját szerkesztés

Általában azokat a turizmusban érintett térségeket (desztinációkat) tekinti a szakma „életképesnek”, önfenntartásra alkalmasnak, amelyek minimum 50 ezer vendégéjszakával rendelkeznek. 22 olyan járás van az Alföldön, ahol ez a kritérium teljesül. Ezek jellemzően a megyeszékhelyeket (Nyíregyháza, Debrecen, Szolnok, Szeged, Kecskemét, Békéscsaba) továbbá többségükben nemzetközi vagy országos jelentőségű fürdőhelyeket (Hajdúszoboszló, Gyula, Berekfürdő, Cserkeszőlő, Mezőkövesd, Cegléd, Orosháza, 
Kiskunmajsa, Mórahalom, Ráckeve) magukban foglaló járások, illetve a Tisza-tó környéki területek (füzesabonyi, tiszafüredi járás).

17. ábra: Vendégéjszakák száma kereskedelmi és egyéb szálláshelyeken az alföldi járásokban (2014)

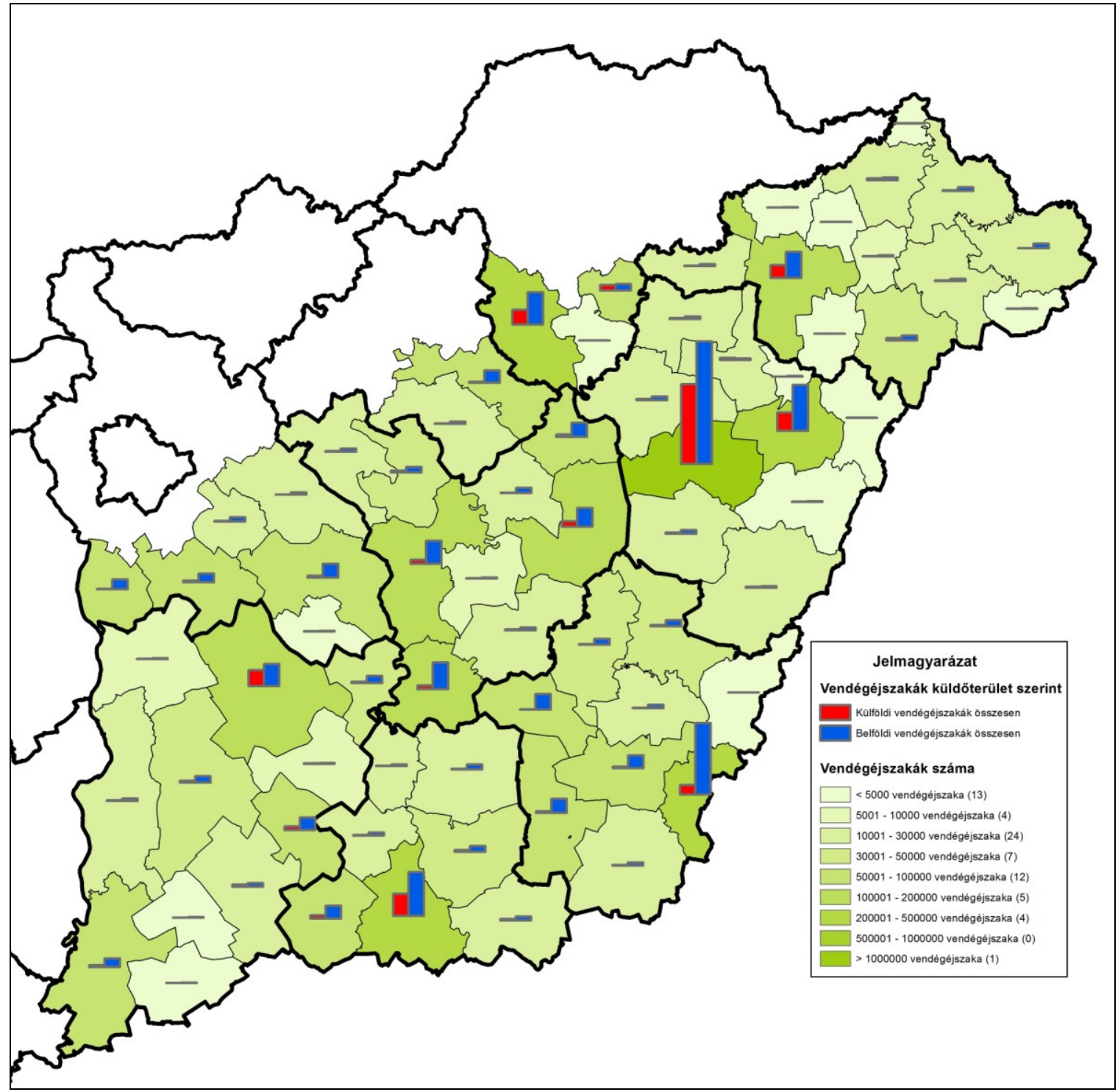

Forrás: KSH TSTAR, saját szerkesztés

Fontos tény, hogy az Alföldre érkező turisták és az általuk eltöltött vendégéjszakák közel 3/4-e a belföldi relációból származik. Nem volt mindig ennyire domináns a belföldi turizmus a térségben, hiszen 1999-ben még 40\% volt a külföldiek aránya, de ez 2014-ig folyamatos csökkenést mutatva 26\%-ra esett vissza. A tartós hanyatlás alapvetően két okra vezethető vissza. Egyrészt nőtt a régióba irányuló belföldi turizmus mértéke, ami relatíve csökkentette a külföldi reláció arányát. Másrészt a külföldi turisták és vendégéjszakáik száma a rendszerváltástól kezdve folyamatosan abszolút értékben is fogyó tendenciát 
mutatott. E kettős folyamat eredményeképpen alakult ki a közelítőleg 3/4-ed - 1/4-ed arány 2014-re. Megállapítható, hogy jelentősebb számú, külföldi vendégek által eltöltött vendégéjszakát csak az alföldi nagyvárosokat és a fürdőtelepüléseket magukban foglaló járásokban regisztráltak, számottevő nemzetközi szintű vonzerővel csak ezek a térségek rendelkeznek.

A fő külföldi küldő országok tekintetében is gyökeres változások zajlottak le az elmúlt évtizedekben. Az 1990-es évek első felét a volt szocialista országokból érkező vendégforgalom erős visszaesése jellemezte, amit tovább súlyosbított a délszláv háború. Fokozatosan egyre inkább az Európai Unió, azon belül is Németország, illetve a szomszédos, közeli országok váltak az Alföld legjelentősebb külföldi küldő piacaivá. Ez utóbbi országcsoport turisztikai szempontból a 2008-ban kezdődő gazdasági-pénzügyi válság nyomán még inkább felértékelödött. Jól látható növekvő reprezentáltságuk a TOP 10 külföldi küldő ország között. A legutóbbi évek adatai szerint Németország továbbra is tartja vezető helyét, ám 2011-2014. között igen drasztikusan, csaknem 20\%-kal csökkent a német vendégéjszakák száma. Szembetünő, hogy a 10 legjelentősebb küldő ország közül csak pont ez a legjelentősebb küldő piac és Ausztria nem tudta növelni részesedését. Noha alacsony bázisról, mégis látványos növekedést produkált viszont a válság idején is Oroszország és Szerbia. Sajátos vonása a szomszédos országokból érkező vendégforgalomnak, hogy legerősebben az adott országhoz közel eső alföldi területekre összpontosul. Így a lengyel, orosz és ukrán turisták elsősorban az észak-alföldi, a szerb vendégek döntő többsége pedig a dél-alföldi desztinációkat keresi fel. A Romániából érkezők szinte egyenletesen oszlanak meg a két térség között. 
7. táblázat: Az Alföld fő külföldi küldő országai 2011-ben és 2014-ben

\begin{tabular}{|c|c|c|c|c|c|c|}
\hline \multicolumn{7}{|c|}{ TOP 10 KÜLFÖLDI KÜLDŐORSZÁG } \\
\cline { 1 - 5 } Helyezés & Ország & $\begin{array}{c}\text { Vendég- } \\
\text { éjszaka }\end{array}$ & Helyezés & Ország & $\begin{array}{c}\text { Vendég- } \\
\text { éjszakáltozás }\end{array}$ & $\mathbf{2 0 1 4 / 2 0 1 1 .}$ \\
\hline $\mathbf{1 .}$ & Németország & 258018 & $\mathbf{1 .}$ & Németország & 206876 & $-19,82 \%$ \\
\hline $\mathbf{2 .}$ & Románia & 134843 & $\mathbf{2 .}$ & Lengyelország & 151630 & $+15,61 \%$ \\
\hline $\mathbf{3 .}$ & Lengyelország & 131156 & $\mathbf{3 .}$ & Románia & 148969 & $+10,48 \%$ \\
\hline $\mathbf{4 .}$ & Szlovákia & 52724 & $\mathbf{4 .}$ & Szlovákia & 69460 & $+31,74 \%$ \\
\hline $\mathbf{5 .}$ & Ausztria & 29955 & $\mathbf{5 .}$ & Ukrajna & 39325 & $+46,42 \%$ \\
\hline $\mathbf{6 .}$ & Ukrajna & 26858 & $\mathbf{6 .}$ & Oroszország & 38451 & $+191,12 \%$ \\
\hline $\mathbf{7 .}$ & Olaszország & 24908 & $\mathbf{7 .}$ & Szerbia & 36196 & $+122,24 \%$ \\
\hline $\mathbf{8 .}$ & Hollandia & 22644 & $\mathbf{8 .}$ & Ausztria & 28856 & $-3,66 \%$ \\
\hline $\mathbf{9 .}$ & Csehország & 21781 & $\mathbf{9 .}$ & Hollandia & 24881 & $+9,88 \%$ \\
\hline $\mathbf{1 0 .}$ & Szerbia & 16287 & $\mathbf{1 0 .}$ & Csehország & 23831 & $+9,41 \%$ \\
\hline
\end{tabular}

Forrás: KSH Tájékoztatási adatbázis, saját számítás

6.4.2. Nem üzleti céllal üzemeltetett közösségi és szabadidős szálláshelyek az Alföldön

Az Alföld fogadókapacitásáról és vendégforgalmáról alkotott kép akkor válik teljessé, ha az „egyéb” és „kereskedelmi” szálláshelyeken túl számba vesszük az ún. „Nem üzleti céllal üzemeltetett közösségi, szabadidős szálláshelyek" nem elhanyagolható csoportját is. Ebbe a kategóriába tartoznak az üdülők (vállalati üdülők, gyermeküdülők, villák); a gyermek- és ifjúsági táborok (vagy pl. telepített sátortábor); a menedékházak (turistaház, kulcsosház, matracszállás), a pihenőházak (munkásszállás, vendégszállás); valamint a diákotthonok és kollégiumok.

A KSH 2004 óta gyüjti ezen szálláshelyek adatait is, de települési szinten - a kereskedelmi és falusi szálláshelyekhez hasonlóan - ott nem közöl adatot, ahol 3-nál kevesebb szálláshely müködik. Mivel a települési és járási szintü elemzések túlzottan nagy adatveszteséggel jártak volna, így ez esetben megyei bontásban, a hat alföldi megyére vizsgáltam a kapacitás és vendégforgalmi adatokat 2004., 2009. és 2014. évekre 
vonatkozásában. Ez idő alatt a 2009. körül mutatkozó hullámvölgy mellett összességében kapacitási és vendégforgalmi adatok erőteljesen növekedtek, bár mindezek ellenére a vendégéjszakák száma a hat alföldi megye összesített adataihoz mérten közel 8\%-os mértékü visszaesést mutatott. Az is megállapítható, hogy ezen szállás- és férőhelyek bővülésének dinamikájától elmaradt a vendégforgalmi mutatók bővülése. Ez a „Nem üzleti célú szálláshelyek” alföldi megyék összesen adatain belüli arányának változásában is tükröződött. Míg a férőhelyekből való részesedésük 10,75\%-ról 14,3\%-ra nőtt, addig a vendégéjszakákon belüli arányuk 6,44\%-ról 5,93\%-ra csökkent 10 év alatt. A megyék közül egyedül Csongrád adatai csökkentek a vizsgált időszakban (24-56\%-kal), s mivel a megye a korábbi években ezen szállástípus tekintetében az élmezőnyben helyezkedett el, a visszaesés erőteljes hatással volt az összesített adatokra.

\section{8. táblázat: Nem üzleti céllal üzemeltetett közösségi, szabadidős szálláshelyek az Alföldi megyékben}

\begin{tabular}{|c|c|c|c|c|c|c|c|c|c|c|c|c|}
\hline \multirow[b]{2}{*}{ Megye } & \multicolumn{4}{|c|}{ Szálláshelyek száma } & \multicolumn{4}{|c|}{ Férőhelyek száma } & \multicolumn{4}{|c|}{ Vendégéjszakák száma } \\
\hline & 2004. & 2009. & 2014. & $\begin{array}{l}2014 / 2004 . \\
(\%)\end{array}$ & 2004. & 2009. & 2014. & $\begin{array}{l}2014 / 2004 . \\
(\%)\end{array}$ & 2004. & 2009. & 2014. & $\begin{array}{c}2014 / 2004 . \\
(\%)\end{array}$ \\
\hline $\begin{array}{c}\text { Bács-Kiskun } \\
\text { megye }\end{array}$ & 11 & 28 & 35 & 318,18 & 976 & 2213 & 2320 & 237,7 & 20528 & 36239 & 35801 & 174,4 \\
\hline Békés megye & 32 & 26 & 54 & 168,75 & 3663 & 1924 & 3751 & 102,4 & 59223 & 29559 & 65365 & 110,37 \\
\hline $\begin{array}{l}\text { Csongrád } \\
\text { megye }\end{array}$ & 38 & 35 & 29 & 76,32 & 3640 & 1913 & 2079 & 57,12 & 81214 & 59151 & 35566 & 43,79 \\
\hline $\begin{array}{l}\text { Hajdú-Bihar } \\
\text { megye }\end{array}$ & 16 & 18 & 36 & 225,0 & 723 & 1038 & 3750 & 518,67 & 23079 & 24306 & 71012 & 307,69 \\
\hline $\begin{array}{l}\text { Jász-Nagykun- } \\
\text { Szolnok megye }\end{array}$ & 14 & 23 & 38 & 271,43 & 852 & 2010 & 1734 & 203,52 & 16956 & 11817 & 25837 & 152,38 \\
\hline $\begin{array}{c}\text { Szabolcs- } \\
\text { Szatmár-Bereg } \\
\text { megye }\end{array}$ & 14 & 19 & 40 & 285,71 & 1215 & 738 & 3612 & 297,28 & 17238 & 32866 & 31587 & 183,24 \\
\hline Összesen & 125 & 149 & 232 & 185,6 & 11069 & 9836 & 17246 & 155,8 & 218238 & 193938 & 265168 & 121,5 \\
\hline $\begin{array}{c}\text { Aránya a } 6 \\
\text { alföldi megye } \\
\text { összesen } \\
\text { adaton belül } \\
(\%)\end{array}$ & 2,8 & 2,81 & 4,46 & 159,29 & 10,75 & 9,09 & 14,32 & 133,21 & 6,44 & 5,27 & 5,93 & 92,1 \\
\hline
\end{tabular}

Forrás: KSH, saját számítás

6.4.3. A falusi turizmus jellemzői a régióban

A vidéki területekre irányuló turizmust Magyarországon a statisztikai adatgyüjtés erőteljesen leszükítve, a „falusi turizmus” és a „falusi szálláshelyek” fogalmaihoz köti. A 
korábbi fejezetekben kitértem rá, hogy a KSH által alkalmazott „falusi turizmus” kategória messze nem fedi le a vidéki területeken realizálódó, vidékies terekben elérhető, azok erőforrásain alapuló tényleges turisztikai vendégforgalmat. Mivel azonban más ilyen jellegü adatgyüjtés nincs, így ennek felhasználásával készítettem elemzéseimet.

Mint korábban ismertettem 1997/98-ig nem volt konkrét szabályozás, adatgyüjtés és statisztikai adatszolgáltatás a falusi turizmus kapcsán, s csak ezt követően alakult ki a jogszabályi környezet, valamint az adatgyüjtés rendszere. A 2009-ben megjelent falusi szálláshelyekre vonatkozó rendeletben foglaltak viszont jelentősen szükítették azon települések körét, ahol egyáltalán végezhető e tevékenység. A statisztikai csak az 5000 fö alatti népességü és 100 fö $/ \mathrm{km}^{2}$ alatti népsürüségü településeken végzett szállásadói tevékenységet tekinti ekkortól falusi turisztikai tevékenységnek. Az új szabályozás a statisztikai adatokban is megmutatkozott. 2010-ben az előző évhez képest alig felére esett vissza a szükített statisztikai adatok szerint a szállásadók és férőhelyek száma, és még jelentősebb mértékben csökkent az így mért vendégforgalom. Persze a csökkenésben a gazdasági válság és az adótörvények 2010-es változása (megszüntették a falusi szállásadásból származó 800 ezer Ft alatti bevétel adómentességét) is szerepet játszhatott.

A statisztikai adatgyüjtés népességi küszöbének változása az Alföldet sajátos településhálózata miatt különösen érzékenyen érintette. 44 település, közte jó néhány jellemzően vidékies adottságokkal rendelkező egykori „kismezőváros” (pl. Bácsalmás, Battonya, Derecske, Dévaványa, Füzesgyarmat, Jánoshalmán, Jászladány, Komádi, Kunszentmárton, Kunszentmiklós, Mezőhegyes, Szeghalom, Tótkomlós, Vésztő) került ki a fogalom „hatálya” és az adatgyüjtés alól. A népsürüségi határ megvonása következtében pedig további több mint 50 alföldi településen (pl. a korábban falusi vendégforgalmat regisztráltak közül Győrtelek, Kocsord, Nagylak, Örkény, Zsombó) nem falusi turizmusként értelmezi a hivatalos statisztika ezen tevékenységet. Ez egyébként szakmailag nehezen magyarázható.

A jogszabályi és a statisztikai adatfelvételben történt változások miatt hirtelen „eltünt” szállásadók „sorsával” kapcsolatban teljesen pontos információk és felmérések nincsenek, de az egyéb (2009-ig magán) szálláshelyekre vonatkozó statisztikai adatok változásából és a szakmai szereplők tapasztataiból használható információkhoz juthatunk. Legnagyobb csoportjuk nem „falusi szállásadóként”, hanem „egyéb szállásadóként” müködik tovább. Erre utal, hogy 2010-ben jelentősen megugrott azon „egyéb szállásadók” száma, amelyek az új besorolás szerint nem tartoznak a falusi szállásadói kategóriába. Fontos tény, hogy szinte ugyanannyi férőhellyel bővült az előzőek köre, mint amennyivel 
ez utóbbiaké csökkent. A vendégforgalmi adatokban ezen átstrukturálódás nem tükröződött, aminek oka lehet az akkoriban kiteljesedő gazdasági-pénzügyi válság. Egy kisebb részük minden bizonnyal felhagyott tevékenységével, más részük feltehetően a szürke gazdaságba tette át tevékenységét.

\section{9. táblázat: Az egyéb (2009-ig magán) szállásadás adatainak változása}

\begin{tabular}{|c|c|c|c|c|c|c|c|c|}
\hline & $\begin{array}{l}\text { Falusi } \\
\text { szállás } \\
\text { adók } \\
\text { száma } \\
\end{array}$ & $\begin{array}{l}\text { Egyéb } \\
\text { szállása- } \\
\text { dók } \\
\text { száma } \\
\text { (kivéve } \\
\text { falusi) } \\
\end{array}$ & $\begin{array}{l}\text { Falusi } \\
\text { szállásférő- } \\
\text { helyek } \\
\text { száma } \\
\end{array}$ & $\begin{array}{l}\text { Egyéb } \\
\text { szállásférőhe- } \\
\text { lyek száma } \\
\text { (kivéve falusi) }\end{array}$ & $\begin{array}{l}\text { Vendégek } \\
\text { száma falusi } \\
\text { szálláshelye- } \\
\text { ken } \\
\end{array}$ & $\begin{array}{l}\text { Vendégek } \\
\text { száma egyéb } \\
\text { szálláshelye- } \\
\text { ken (kivéve } \\
\text { falusi) } \\
\end{array}$ & $\begin{array}{l}\text { Vendégéj- } \\
\text { szakák } \\
\text { száma falusi } \\
\text { szálláshelye- } \\
\text { ken }\end{array}$ & $\begin{array}{l}\text { Vendégéj- } \\
\text { szakák } \\
\text { száma egyéb } \\
\text { szálláshelye- } \\
\text { ken (kivéve } \\
\text { falusi) } \\
\end{array}$ \\
\hline 2008. & 1793 & 3373 & 12091 & 23376 & 53340 & 153678 & 195839 & 573651 \\
\hline 2009. & 1938 & 3648 & 13146 & 25741 & 60921 & 152649 & 199138 & 537377 \\
\hline 2010. & 1055 & 6401 & 5347 & 32725 & 28238 & 167941 & 96197 & 543746 \\
\hline 2011. & 1034 & 6475 & 5321 & 31871 & 31534 & 166412 & 95989 & 513111 \\
\hline 2012. & 796 & 4472 & 5855 & 31183 & 24503 & 188339 & 64009 & 574575 \\
\hline $\begin{array}{l}\text { Válto- } \\
\text { zás } \\
2010 / \\
2009 .\end{array}$ & -883 & 2753 & -7799 & 6984 & -32683 & 15292 & -102941 & 6369 \\
\hline
\end{tabular}

Forrás: KSH TSTAR, saját számítás

Az alföldi falusi szállásadók és férőhelyek, valamint a vendégek és vendégéjszakák országon belüli aránya jelentősen elmarad attól, amit a térség adottságai alapján előzetesen becsülhető volt. A kapacitási mutatók adatgyüjtés kezdetekor mért 18-19\%-os részesedése biztató emelkedésnek indult a 2000-es évek közepéig, és elérte a 25-27\%-os szintet, majd 2009-ig kisebb visszaesés, illetve stagnálás következett, 2010-től pedig csökkenésnek indult, és 2014-re 24\%-os szintre állt be. Ez kisebb arányvesztés, mint a vendégek és vendégéjszakák vonatkozásában. Ott is hasonló tendenciák figyelhetők meg azzal a különbséggel, hogy a kezdeti növekedési szakasz intenzívebb volt, mint kapacitási mutatók esetén: a vendégek aránya 2004-ben megközelítette a 28\%-ot, a vendégéjszakáké pedig a 30\%-ot, de a csökkenés itt is bekövetkezett, s 2014-re 22, illetve 21\%-ra esett vissza a két mutató.

A falusi turizmus keretében eltöltött vendégéjszakák aránya az Alföld számszerüsített és KSH által mért turisztikai összteljesítményéből jelentős változásokat mutatott az elmúlt bő 15 év alatt. A kezdeti (1999-es) 3\% körüli értékről 2009-re 5\%-ra nőtt, majd 2014-re 1,6\%-ra esett vissza, ami igen csekély arány. A 70 alföldi járás falusi turizmusra vonatkozó adatai alapján tehát az egész szektor teljesítménye egyenletes emelkedést mutatott a 2000es évek közepéig. A férőhelyek száma még nagyobb ütemben is nőtt, mint a szállásadóké. Ennek nyomán 5,9-ről 6,6-ra nőt az egy szállásadóra jutó férőhelyek száma. A 2005-ben 
történt 25\%-os kapacitás csökkenés 3 év alatt kompenzálódott, sőt 2009-re fogadóképességének addigi csúcspontját érte el az ágazat. A 2010-től hatályba lépett jogszabályi változások, valamint a gazdasági pénzügyi válság következtében azonban drasztikus visszaesés következett be, a szállásadók és a férőhelyek száma csaknem felére csökkent, s a hivatalos statisztika szerint 2014-ben kevesebb szállásadó és alig valamivel több féröhely volt az Alföldön, mint az adatgyüjtési rendszer indulásakor, 1998-ban. Ez különösen ellentmondásos annak ismeretében, hogy a 2010 előtti trendek és az Európai Mezőgazdasági és Vidékfejlesztési Alap III. tengelye által nyújtott szálláshely fejlesztési támogatásoknak köszönhetően valójában növekedni kellett volna a férőhelyek számának.

\section{8. ábra: A falusi szállásadók és férőhelyek számának alakulása az Alföldön}

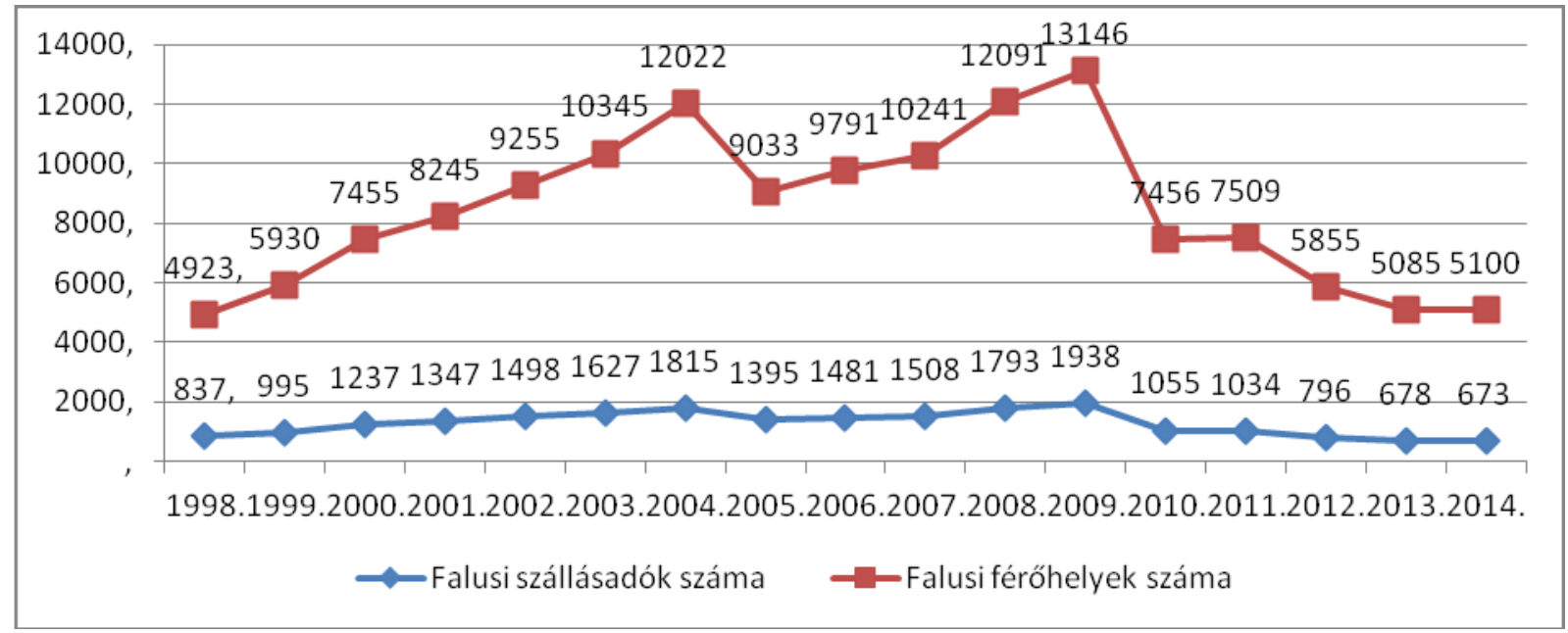

Forrás: KSH TSTAR, saját szerkesztés

A szállásadók és féröhelyek számában 2005. körül megmutatkozó első csökkenő szakasz a vendégforgalmi adatok vonatkozásában már némileg korábban (2003-2004-ben) jelentkezett. A második (2009/10-es) drasztikus visszaesés a vendégforgalmi adatokban is jól tetten érhető. Mind a vendégszám, mind a vendégéjszakák száma egyik évről a másikra több mint 50\%-kal csökkent a hivatalos statisztikai adatok szerint, sőt a következő években ez a trend tovább folytatódott. Egyedül 2014-ben mutatkoztak némi jelei a kilábalásnak.

A lakosság utazási szokásai jellemzően átalakultak az utóbbi 10-15 évben. A gyakoribb, de rövidebb időtartamú utazások kerültek előtérbe. A falusi turizmus statisztikai adatai is ezt igazolják vissza. A vendégéjszakák és a vendégszám hányadosaként számított átlagos tartózkodási idő a vizsgált időszakban évről-évre folyamatosan csökkent, 4,3-ról 2,7 napra, azaz több mint harmadával esett vissza. 
19. ábra: A falusi turizmus vendégforgalma az Alföldön

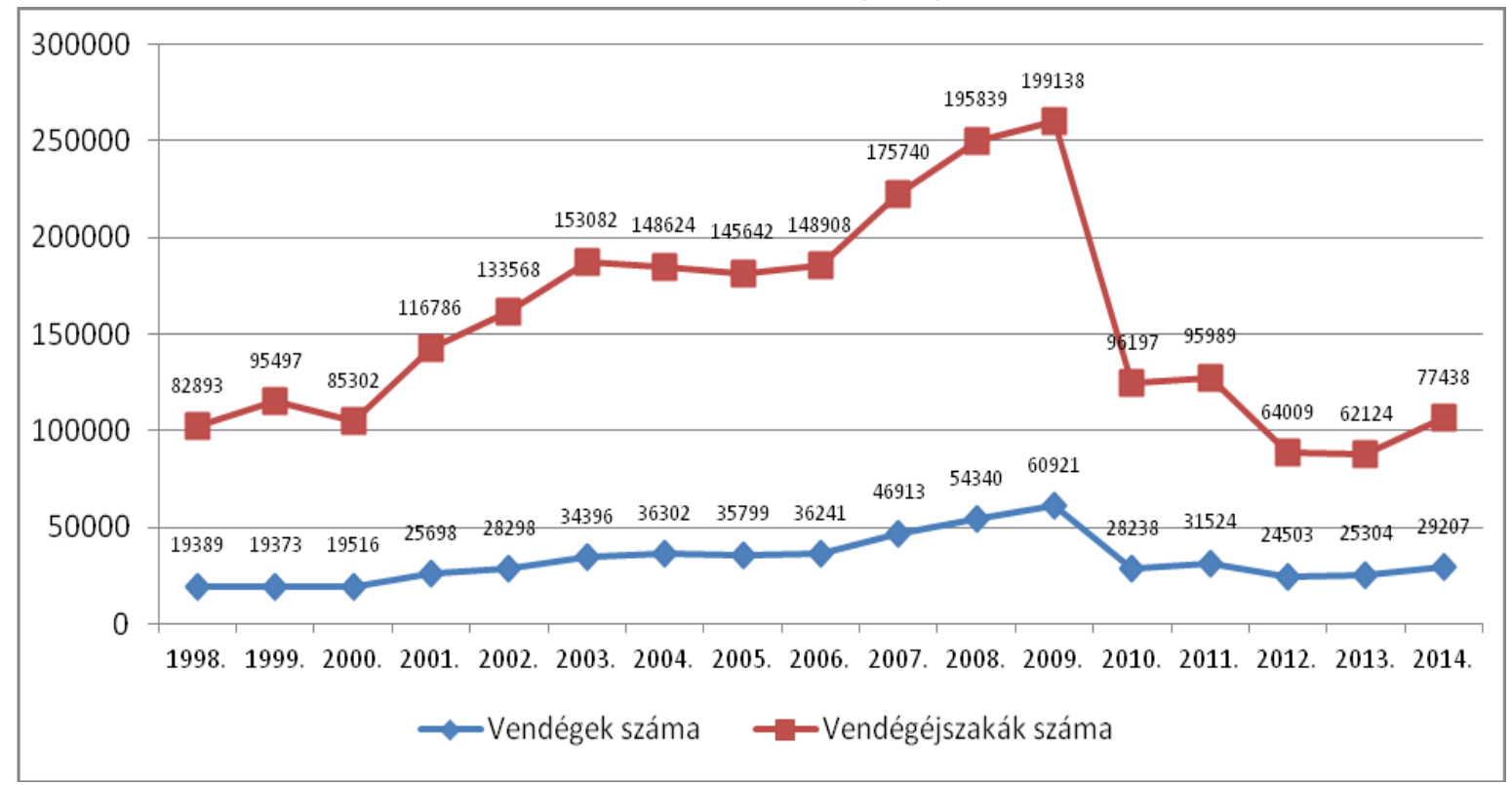

Forrás: KSH TSTAR, saját számítás

Az alföldi falusi szálláshelyeken eltöltött vendégéjszakák az összes alföldi vendégéjszakához hasonlóan döntően a belföldi turizmusból származnak annyi különbséggel, hogy még nagyobb a belföld „,fölénye”: az utóbbi 15 évben rendre 70\% fölött volt a belföldi vendégéjszakák aránya. Egyébként az egész Európai Unióban jellemző ebben az ágazatban a belföldi forgalom nagy, illetve döntő aránya.

\section{0. ábra: A külföldi és belföldi vendégéjszakák aránya a falusi turizmus} vendégforgalomban az Alföldön

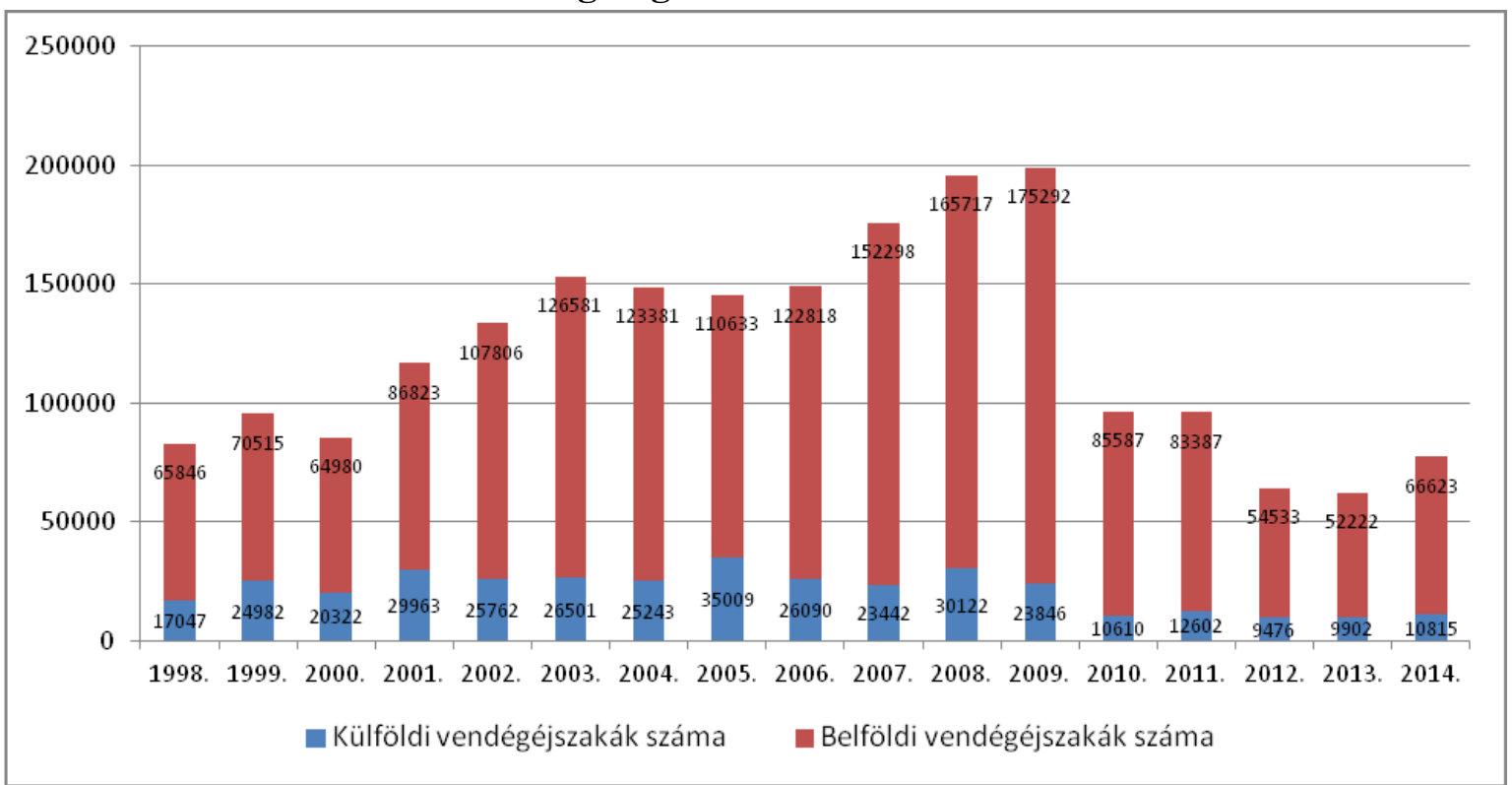

Forrás: KSH TSTAR, saját számítás 
Elemzéseim megerősítették, hogy amit hazánkban a jogszabályok és az adatgyüjtési rendszer (különösen 2010-től) a „falusi turizmus” fogalmához hozzárendelt, az nem tükrözi a vidéki területekre irányuló turizmus valós teljesítményét. Nem fedi a valóságot, hogy az Alföld turisztikai összteljesítményéből ilyen kis részt képviseljen a vidéki területek turizmusa.

\subsubsection{A falusi turizmus térbeli sürüsödései}

Az alföldi járások 786 településéböl 168 területén, közte 18 városban regisztráltak az új szabály alapján falusi turizmus keretében eltöltött vendégéjszakát 2014-ben. (Összehasonlításképpen a jogszabályi változások előtt, 2009-ben még 246 településen volt ilyen típusú vendégfogadás.) A forgalom meglehetősen alacsony intenzitású, amit jól példáz, hogy a 168-ból 53 helyhatóság esetén maradt 100 vendégéjszaka alatt az éves teljesítmény. Csak 20 település érte el az 1000-es, és mindössze nyolc (Ásotthalom, Ebes, Hortobágy, Inárcs, Szatmárcseke, Szigetbecse, Szihalom, Túrkeve) a 2000-es határt.

A járások teljesítménye a falusi turizmus terén az 1000 lakosra jutó vendégéjszakák alapján hasonlítható össze. Feltünően magas ez a fajlagos szám több olyan járás esetén (hajdúszoboszlói, ráckevei, mórahalmi, makói, mezőkövesdi), amely legalább regionális jelentőségü fürdővel rendelkezik, de Szatmár-Beregben és a Tisza-tó környékén is több járásban átlag feletti a mutató értéke. Ez esetben a más turisztikai mutatókban gyenge jánoshalmi járás is a legfelsőbb kategóriába került annak köszönhetően, hogy több mint 1900 vendégéjszaka keletkezett 3 szolgáltatónál. (Ez az adat ugyanakkor akár nagyon csalóka is lehet, hiszen adódhat egy nagyobb környékbeli infrastrukturális beruházás munkásainak elszállásolásából.) 


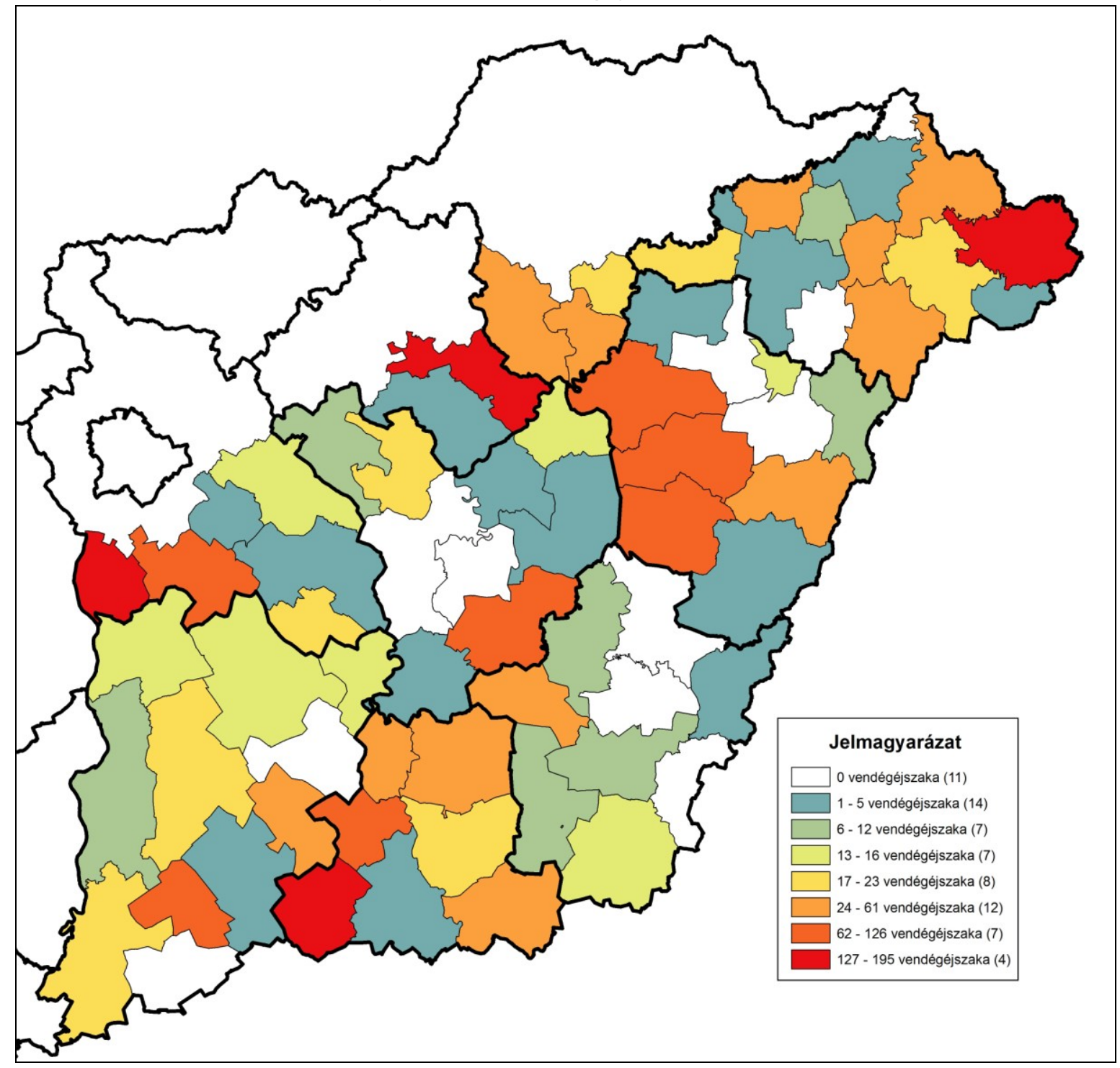

Forrás: KSH TSTAR, saját számítás

A falusi vendégéjszakák települési szintű adatainak térképi ábrázolása tovább finomítja a jelenség előzőekben körvonalazódó térbeli képét. A legegyértelműbb és legmarkánsabb csomópont ezek közül Szatmár-Bereg térsége (a fehérgyarmati és a vásárosnaményi járás települései), de jól azonosítható a Hortobágy térsége; a Tisza-tó mente, Hajdú-Bihar megye délnyugati része (püspökladányi, derecskei járás települései). További térbeli csoportok fedezhetők fel a Duna-Tisza-közi Homokhátságon, annak északnyugati részén a dabasi, kunszentmiklósi és kecskeméti járás, továbbá déli, dél-keleti részén a mórahalmi, kisteleki, csongrádi járás területén. De beazonosíthatók a Duna-menti területek is a ráckevei, kalocsai és bajai járásokban eltöltött magasabb vendégéjszakák révén. 


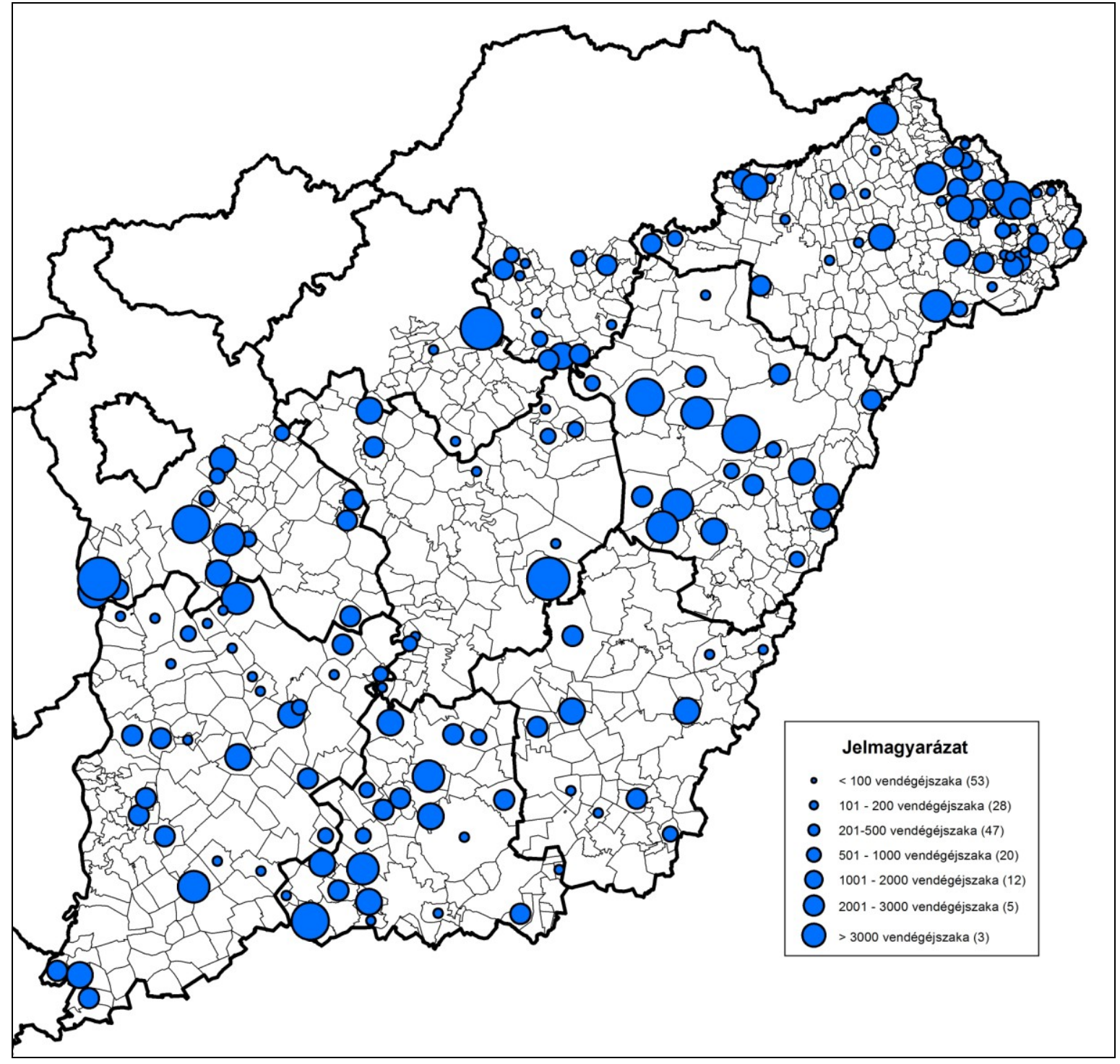

Forrás: KSH TSTAR, saját számítás

\subsubsection{Falusi szálláshelyek minőségi kategóriái}

A falusi turizmusban érintett szálláshelyek összehasonlíthatósága és a szolgáltatások minőségének emelése céljából hozta létre a Nemzetgazdasági Minisztérium együttmüködve a FATOSZ-szal a „Falusi szálláshely napraforgóval” Nemzeti Tanúsító Védjegyet. Ennek alapvető célja, hogy garantálja a falusi szálláshelyek szakmai elvárásoknak megfelelő színvonalát, és támpontot nyújtson a fogyasztónak, a turistának az adott vendégfogadónál 
elérhető és elvárható szolgáltatások minőségéről. A szálláshelyek minősítése a FATOSZ által kidolgozott szakmai szempontrendszer szerint történik ${ }^{13}$. A szálláshelyek 1-4 napraforgós minősítést nyerhetnek el felszereltségüktől és komfortosságuktól függően.

Az EMVA-ból nyújtott szálláshely-fejlesztési támogatások egyik feltétele a minősítés megszerzése, így nem véletlen, hogy a 2007-13-as Európai Uniós fejlesztési ciklus kifizetéseinek felfutásával szinte egyenes arányban nőtt a minősített „házak” száma is.

2015. decemberéig 1210 vendégfogadó szerezte meg hazánkban a napraforgós minősítés valamely fokozatát. Az alföldi szállások igen erőteljesen, a térség területarányának megfelelően reprezentáltak a minősítettek között, hiszen 461 „ház” található az általam vizsgált járásokban, ami az Alföld országon belüli területarányával szinte azonos, 38,1 \%-os részt képvisel. Az is figyelmet érdemel, hogy Alföldön lévő minősített szálláshelyek nagy többsége $(81,1 \%$-a) a legmagasabb minőségi szintet képviselő 4 napraforgós kategóriába tartozik. Ebből arra is következtethetünk, hogy a vizsgált régiónkban ezt a tevékenységet jó színvonalon szeretnék biztosítani a tulajdonosok. Ebben nyilván az EU-s támogatásoknak is jelentős szerepe lehetett.

A minősített szállások térbeli sűrűsödései - értelemszerüen - a már vizsgált szálláshely kapacitások terén mutatkozó csomópontokkal esnek egybe. A szatmár-beregi térségben, a Tisza-tó környékén, a Hortobágyon és Hajdú-Bihar megye Dél-nyugati részén, valamint a Duna-Tisza-közi Homokhátság területén egyaránt magasabb számban vannak jelen a Nemzeti Tanúsító Védjeggyel rendelkező falusi szálláshelyek. Kiemelkedően magas a minősített szállásadók száma a szarvasi és a fehérgyarmati járásban. (A hivatalos statisztikai adatgyüjtés anomáliáira utal, hogy ezzel szemben nem mért falusi vendégéjszakát a szarvasi járásban pl. a legtöbb védjegyes szálláshellyel rendelkező Békésszentandráson). Kilenc térségben, közte a Nagykunság jelentős területein (karcagi és törökszentmiklósi járás) és Hajdúság bizonyos részein nincsenek napraforgós Nemzeti Tanúsító Védjeggyel rendelkező szállások.

\footnotetext{
${ }^{13}$ A napraforgós Nemzeti Tanúsító Védjegy 2011-es bevezetése előtt is létezett a szálláshelyek minőségi kategóriáinak ugyanilyen szimbólummal történő megjelölése, melyez szintén a FATOSZ gondozott.
} 


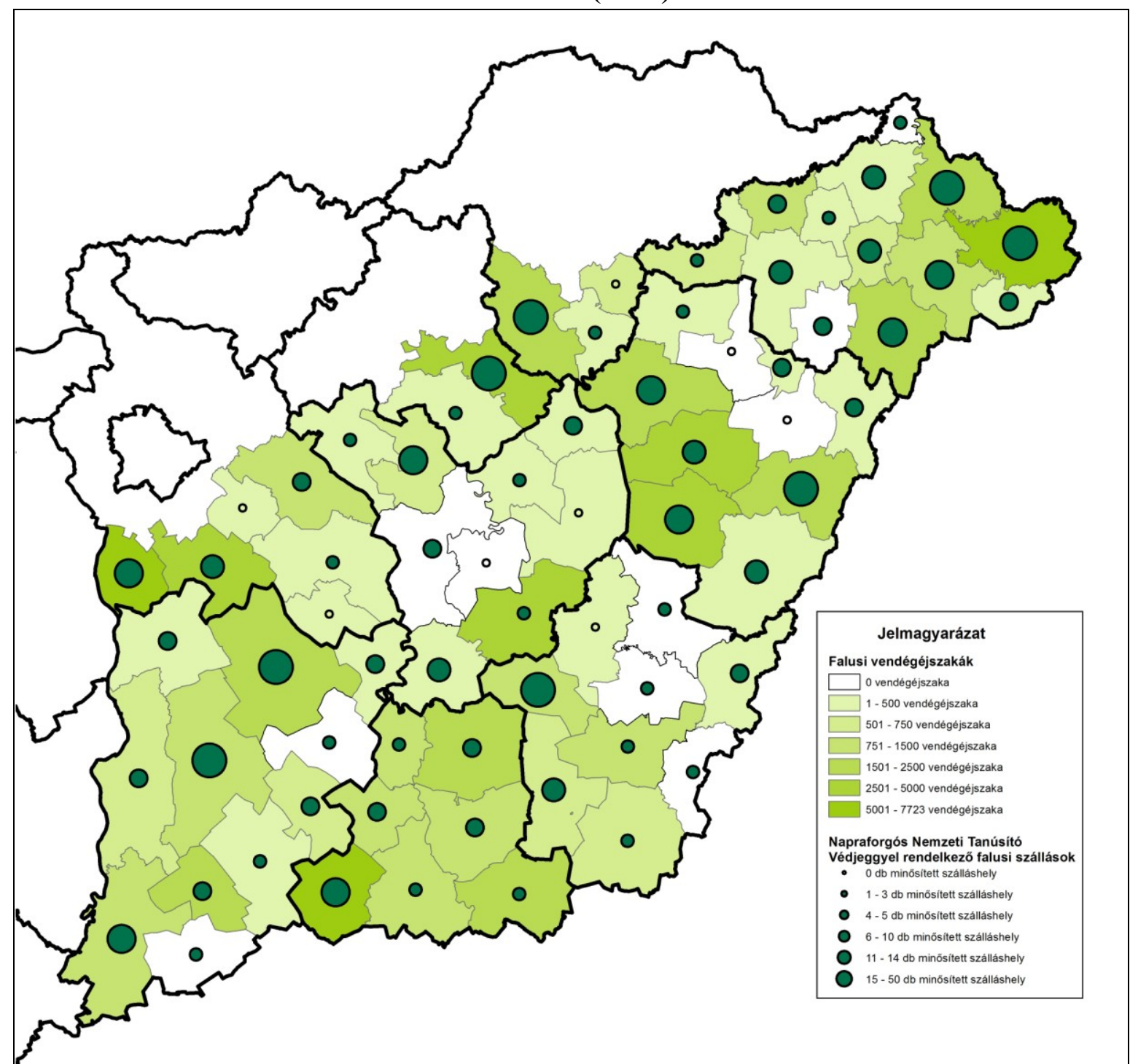

Forrás: FATOSZ, saját számítás

\subsubsection{Kísérlet a vidékturizmus teljesítményének mérésére}

Mint jeleztem, a vidékturizmus teljesítményének számszerü mutatókkal történő kifejezése nehézségekbe ütközik, mivel a KSH nem végez ilyen tartalmú adatgyüjtést. Arra viszont mód nyílik, hogy a meglévő statisztikai apparátus felhasználásával legalább közelítő számításokat végezzünk.

Mint bemutattam a vidékturizmus koncepciómban, ahol a turisztikai termékek és a tértípusok különböző kombinációit vázoltam fel: a négy lehetséges kombináció közül csak 
a városias térben elérhető városias turisztikai termékeket nem tekintem e fogalom részének. Az Alföld turizmusa teljesítményének mérésére ez esetben is a kereskedelmi és egyéb szálláshelyeken eltöltött vendégéjszakák számát alkalmazom. A vidékturizmus koncepció alapját a tértípusok (vidéki, köztes, városi) jelentik, ezek szerint differenciálhatók a különböző turizmusfajták, s a regisztrált vendégéjszakák. (A KSH adatgyüjtésében szereplő a kereskedelmi és egyéb szálláshelyek vendégéjszaka adatai térségtípusonként vizsgálhatók.) Mint jeleztem az általam vizsgált 70 alföldi járás nagy többsége vidékies (61 db), és a városias járások közül a népsürüséget tekintve több inkább átmenetinek tekinthető. Számításaim során tehát a vidékies és átmeneti járások KSH által, a kereskedelmi és egyéb szálláshelyeken mért adatait vettem figyelembe a vidékturizmus számszerüsített teljesítményének vizsgálatakor. Két területi szinten (járási és települési) összegeztem a rendelkezésre álló adatokat, szükebb és bővebb értelmezés szerint. Előbbi során a térségtipizálások alapján városias 9 járás, illetve települési szinten járásközpont adata nélkül, míg utóbbi esetében a három legurbanizáltabb járás (debreceni, szegedi, nyíregyházi), illetve járásközpont adata kivételével.

10. táblázat: A vidékturizmus teljesítménye a vendégéjszakák száma alapján

\begin{tabular}{|c|c|c|c|c|}
\hline & \multicolumn{2}{|c|}{ Járási szint } & \multicolumn{2}{|c|}{ Települési szint } \\
\hline & db & $\%$ & db & $\%$ \\
\hline Összes vendégéjszaka & 4.815 .194 & 100 & 4.815 .194 & 100 \\
\hline $\begin{array}{lr}\begin{array}{l}\text { Vidékturizmushoz } \\
\text { vendégéjszakák }\end{array} & \begin{array}{r}\text { köthető } \\
\text { szűkebb }\end{array} \\
\text { értelmezés szerint } & \end{array}$ & 3.456 .147 & 71,8 & 3.584 .628 & 74,4 \\
\hline $\begin{array}{ll}\begin{array}{l}\text { Vidékturizmushoz } \\
\text { vendégéjszakák }\end{array} & \begin{array}{l}\text { köthető } \\
\text { bővebb }\end{array} \\
\text { értelmezés szerint } & \end{array}$ & 3.946 .675 & 82,0 & 3.966 .381 & 82,4 \\
\hline
\end{tabular}

Forrás: KSH, TeIR, saját számítás

Az alföldi tér, a régió vonzeröi és az ezekre épülö turisztikai termékek vidékies karaktere a turizmus e teljesítménymutatójában is tükröződnek. Mindkét értelmezés szerint magas, a régió vendégéjszakáinak 70\%-át meghaladó a vidékturizmushoz köthetők aránya.

A vidékturizmus kapcsán két alföldi térségre mindenképpen szükséges külön kitérni. Noha a hajdúszoboszlói és gyulai járás vidékiesnek tekinthető, turizmusuk nagyságrendje és főleg intenzitása megkérdőjelezheti az e fogalomhoz való tartozásukat. A koncepció 
alappillére azonban a tér, amelyben a turisztikai termékek keletkeznek, így a vidékturizmushoz tartozónak vélem mindkét térséget a vidékies térségben elérhető köztes vagy városias turisztikai termékekkel. 


\subsection{Az Alföld turizmusa - a benne részt vevő szakmai szereplők megkérdezésével}

Az Alföld turisztikai vonzerőinek áttekintése és a turizmus kvantitatív adatainak elemzése mellett az Alföld turizmusáról alkotott kép teljesebbé tételéhez primer kutatást folytattam a turisztikai szektor szereplöi körében különös tekintettel a statisztikában kedvezőtlenül megjelenő a falusi vendéglátókra.

Kutatásaim keretében nem valószínűségi mintavételi eljárással on-line kérdőíves felmérést végeztem az alföldi turisztikai szakmai szereplök (falusi szállásadók, egyéb szállásadók, kereskedelmi szálláshelyek, turisztikai szolgáltatók, turisztikai szervezetek és LEADER Helyi Akciócsoportok) között (kérdöív az 1. sz. mellékletben). Célom az volt, hogy lehetőleg átfogó képet kapjak arról, hogyan értékelik a turisztikai szektor alföldi szereplői a térség belső erőforrásait; milyen az e szempontból fontos társadalmi erőforrások állapota, különös tekintettel a szektor szereplőinek együttműködésére, azok erősségére és minőségére. Azért választottam ezt a mintavételi módszert, mert a kutatás célja - a szakmai szereplők véleményének, attitűdjének feltárása - ezt lehetővé tette. A hasonló célzatú kutatások során általában nem alkalmazzák a nagy humán erőforrás igényü és igen költséges valószínűségi mintavételi eljárásokat. Így ugyan kutatáson nem tekinthető reprezentatívnak, de a megkérdezett csoportok véleményének fő irányairól összetett és érdemi tartalmakat tükröző képet mutat.

A kérdőíveket Google űrlapokként készítettem el és küldtem szét a fentiekben jelzett szakmai szereplők e-mail címére. Konkrétan 672 falusi szállásadónak, 923 egyéb szállásadónak, 586 kereskedelmi szálláshelynek, 207 turisztikai szolgáltatónak, 65 turisztikai szervezetnek, és a turisztikai fejlesztésekben érdekelt 41 LEADER Helyi Akciócsoportnak.

Összesen 484 kérdőív érkezett vissza az alábbiak szerint:

11. táblázat: A kérdőívekre beérkezett válaszok

\begin{tabular}{|l|c|c|}
\hline \multicolumn{1}{|c|}{ Célcsoport } & $\begin{array}{c}\text { Beérkezett kérdőívek } \\
\text { száma }\end{array}$ & Visszaküldési arány \\
\hline Falusi szállásadók & 162 & $24,1 \%$ \\
\hline $\begin{array}{l}\text { Egyéb (2009-ig magán) } \\
\text { szállásadók }\end{array}$ & 122 & $13,2 \%$ \\
\hline Kereskedelmi szálláshelyek & 118 & $20,1 \%$ \\
\hline
\end{tabular}




\begin{tabular}{|c|c|c|}
\hline Turisztikai szolgáltatók & 51 & $24,6 \%$ \\
\hline Turisztikai szervezetek & 17 & $26,1 \%$ \\
\hline $\begin{array}{ll}\text { LEADER } & \text { Helyi } \\
\text { Akciócsoportok } & \end{array}$ & 14 & $35 \%$ \\
\hline Összesen: & 484 & $19,4 \%$ \\
\hline
\end{tabular}

Forrás: a beérkezett kérdőívek alapján saját szerkesztés

A válaszadási hajlandóság jó szintet ért el. Külön sikerként értékelem, hogy előzetes várakozásaimmal szemben a falusi szállásadók közel negyede a kérdőív visszaküldésével véleményt nyilvánított a témát illetően. Az „egyéb” (korábban magán) szállásadóknál adódó alacsonyabb visszaküldési arány nem meglepő, hiszen nagyon heterogén és széttagolt csoportról van szó, akik nem szívesen nyilvánítanak véleményt.

A válaszokat a Google ürlap alkalmazás táblázatos formában rögzítette, majd az adatok .xls formátumban kerültek átkonvertálásra. Végül SPSS 22.0, Microsoft Excel és ArcMap 10.2 szoftverek segítségével kerültek rendszerezésre, feldolgozásra és ábrázolásra.

A beérkezett válaszokat egyrészt valamennyi célcsoport válaszait együttesen figyelembe véve, másrészt a falusi szállásadók csoportjára szűkítve értékeltem. Így az összes válasz alapján átfogó, a szükített válaszadói csoport révén pedig speciális képet kaphattam a régió vidékeinek belső-, és elsősorban társadalmi erőforrásairól. A legtipikusabb vidékturisztikai térségekből, illetve a turisztikai szempontból frekventált területeiről érkező válaszokat külön is elemeztem.

\subsubsection{Az Alföld turizmusának jellemzői az összes megkérdezett szerint}

Az összes válaszadó nemek közötti megoszlása enyhe eltérést mutatott a nők javára. A kérdőíveket kitöltők 43\%-a férfi, 57\%-a nö. Magasan reprezentáltak közöttük a felsőfokú végzettséggel rendelkezők, mintegy 2/3-uk rendelkezett a diplomával. Mindössze 6 válaszadónak volt csak alapfokú végzettsége. Turisztikai végzettséggel a válaszadók 43,2\%-a rendelkezett, több mint harmaduk felsőfokú, 60\%-uk középfokú (jellemzően OKJs) képzettséggel bír. Az egy idegen nyelvből legalább alapfokú nyelvismerettel rendelkezők aránya közel 70\%-os. Az alapfokú végzettségüek 1/6-a, a középfokúak közel fele (több mint 48\%-a), a felsőfokúak több mint $80 \%$-a beszél idegen nyelvet. Leggyakrabban az 
angolt középfokon (a válaszadók több mint 1/3-a), és németet alapfokon (30\%) müvelik, de az államszocializmus idején kötelezően tanult orosz nyelvet is több mint 50-en (több mint 15\%) beszélik alapfokon. Megállapítható tehát, hogy a válaszokat visszaküldő turizmussal foglalkozók jól kvalifikáltak voltak mind az általános, mind a szakmai végzettségüket, mind idegen-nyelvtudásukat illetően.

A belső erőforrásokra adott értékelések alapján egyértelmüen kitünik, hogy a természet alkotta erőforrásokat, azon belül is sorrendben a felszíni és felszín alatti vizeket és a természeti értékeket („Tájkép, természetvédelmi területek” és „Állat- és növényvilág”) tartják legfontosabbnak. Ezen három tényező karakteresen kiemelkedik a többi közül, amit az is jelez, hogy a válaszok legalább felénél „Inkább jelentős” és „Nagyon jelentős” minősítést kaptak. Az Alföld erőteljes agrártradícióinak és vidékiségének fontosságát jelzi, hogy válaszadók majdnem fele (40-50\%-a) ítélte inkább- vagy nagyon jelentősnek a termőföldet, illetve az ember alkotta erőforrások közül pedig a mezőgazdasághoz kapcsolódó értékeket és a helyi élelmiszereket, valamint a vidéki életmódot. Szinte teljesen azonos fontosságúnak ítélték még a kulturális örökséget és a hagyományokat, valamint az azokhoz kapcsolható rendezvényeket és fesztiválokat. A térségek jövője szempontjából bizakodásra ad okot, hogy két jelentős humán tényezőt is („Helyi identitás” és Települések közötti jó kapcsolat”) magasra értékeltek. Ugyanakkor egyáltalán nem reményt keltő, hogy a humán erőforrások minősége az egyik leggyengébb minősítést kapta. A szakma értékelése egyértelműen felhívja a figyelmet ennek gyengeségére, és egyben kijelöli a térség jövőbeli fejlesztésének kívánatos irányát is. Mindezekhez kapcsolódik kérdőíves felmérésem egy másik része, mely során az elmúlt 10 év fejlesztéseinek fő irányvonalait is összegeztem. Tanulságos volt látni, hogy a válaszadó szakmai szereplők az elmúlt időszakban alig helyeztek hangsúlyt saját fejlesztéseik között a humán tényezőkre. Több mint 80\%-uk hajtott végre valamilyen volumenű attrakció vagy szálláshely fejlesztést, ám ezek nagy többsége a szállásférőhelyek és szolgáltatások bővítésére vonatkozott, kifejezetten a humán erőforrásokba alig 5\%-uk invesztált. Így nem meglepő, ha azokat maguk is általában gyengének minősítették. 
24. ábra: Az Alföld belső erőforrásai az összes válaszadó szerint

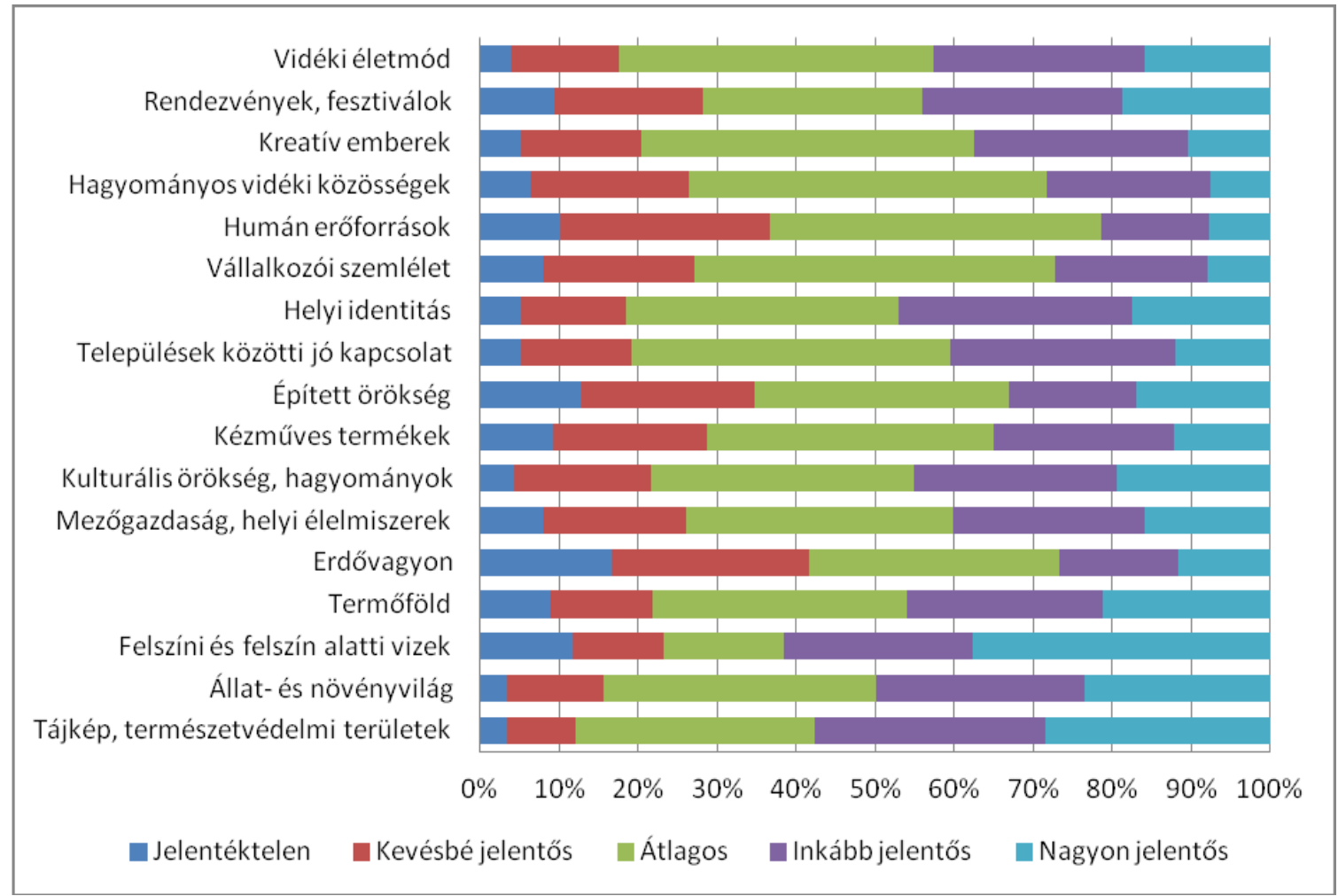

Forrás: a beérkezett kérdőívek alapján, saját szerkesztés

A belső erőforrás csoportok egymáshoz viszonyított arányának és térbeli képének meghatározásához első lépésként járásonként átlagoltam a természethez és a humán tényezőkhöz kötődő erőforrások válaszadók által adott pontértékeit. Majd kiszámítottam a két fö erőforrás csoport átlagát. Ezt követően a két értéket a járásban eltöltött vendégéjszakákat is ábrázoló térképen tüntettem fel. Az átlagolásokból adódóan nem szóródtak széles skálán a két erőforrás csoport értékei, de ezen egyszerüsítésekkel is szembetűnőek az aránybeli különbségek és a területi sajátosságok. Felismerhetők a folyók mentén és a természetvédelmi területeken lévő térségek, ahol a természethez kötődő tényezők magasabb arányban jelentek meg a válaszokban. A megyeszékhelyek és nagyvárosok környezetében jóval kiegyenlítettebb a kép, sőt több esetben a humán tényezők erőteljesebb szereppel bírnak a válaszadók szerint. 


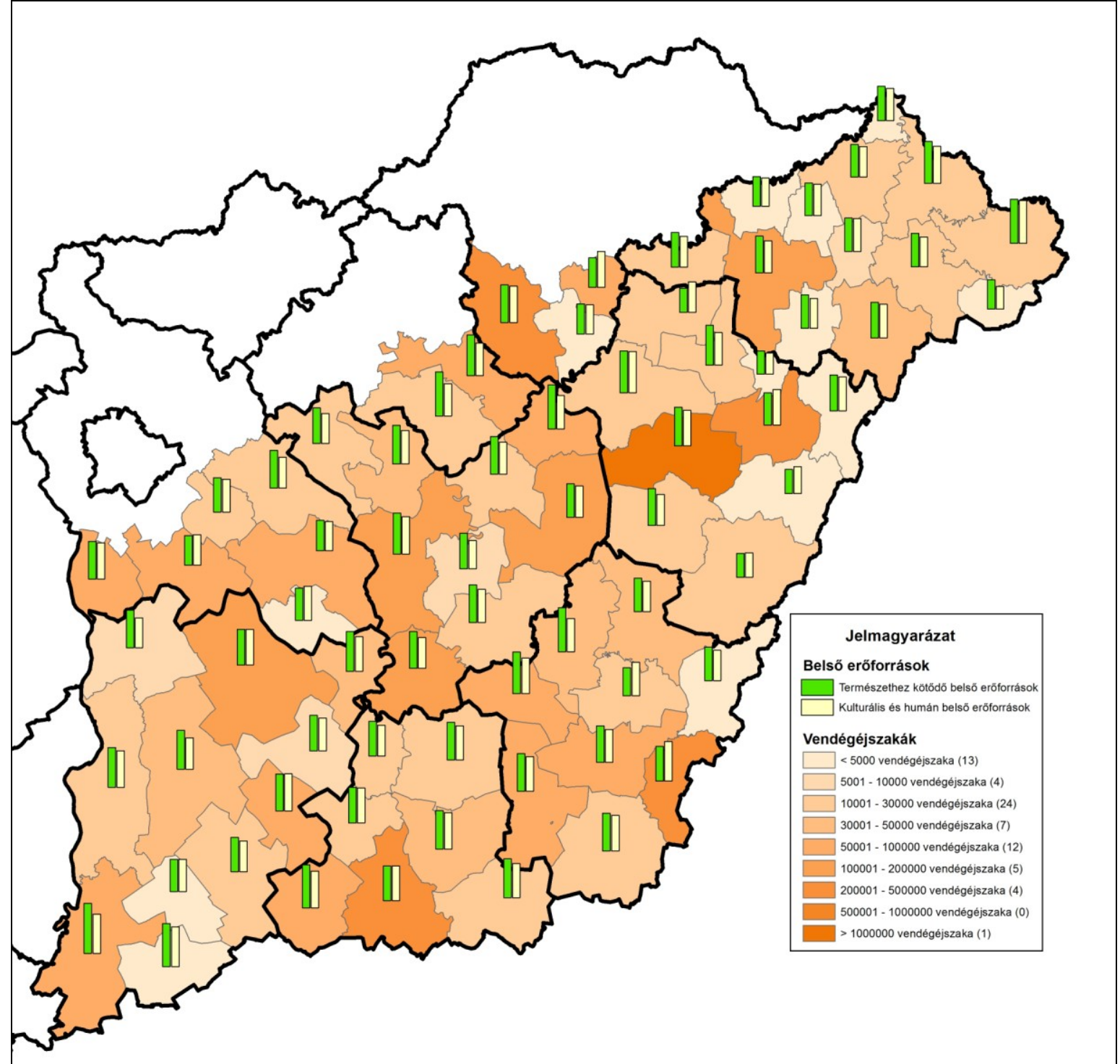

Forrás: beérkezett kérdőívek alapján saját szerkesztés

A belső erőforrások és a turizmus teljesítménymutatóinak korrelációs vizsgálata a mutatók közötti kapcsolat erősségére és irányára utal. A falusi vendégéjszakákkal legerősebb pozitív összefüggésben lévő tényezők között a természethez (tájkép, vizek) és emberhez kötődőek (kulturális örökség, vidéki közösségek, vidéki életmód és identitás) egyaránt megfigyelhetők, míg a kereskedelmi szálláshelyek teljesítményét jelző vendégéjszakákkal elsősorban a humán tényezők mutatnak erősebb korreláltságot. A természet alkotta erőforrások közül csak a vizek esetén mondható el ugyanez. Markánsan kirajzolódik ezen vizsgálat mentén is, hogy az alföldi turizmus teljesítményére több belső erőforrás együttesen van hatással, de a vizek (termálvizek) dominanciája ez esetben is szembetünő. Míg a legtöbb erőforrást változó erősségü és irányú kapcsolat füzi a 
szállástípusonkénti vendégéjszakákhoz, a vizek valamennyi esetben az átlagnál erősebb összefüggést mutatnak.

Egy adott településen vagy térségben a turisztikai kínálat nagyon sok elemből tevődik össze, s a termék létrejöttéhez, vagy más aspektusból közelítve a fogyasztó, a turista kiszolgálásához elengedhetetlen a szektor szereplöi közötti harmonikus együttmüködés. Nagyon bíztató, hogy a válaszadók több mint 85\%-a kooperál a szükebben vett turisztikai ágazat valamely másik szereplőjével (szállásadó, vendéglátóhely, programszervező). Az viszont már kevésbé pozitív, hogy a kérdőívet kitöltők közel fele (43\%) átlagosnak ítéli az együttmüködést, s csak 10\%-uk érzi erősnek. 60\%-uk a turisztikai szektorhoz kapcsolódó egyéb szereplőkkel (helyi termék előállító kistermelők, erdészet, Nemzeti Park Igazgatóság, stb.) is együttmüködik. Ez esetben még magasabb arányban (60\%) érzik átlagosnak, középszerünek a közös munkát. Az előző csoporthoz hasonlóan 1/10-ük ítéli csak erősnek az együttmüködést.

Érdekesebb viszont az együttmüködések erősségének térbeli képe, különösen, ha párhuzamosan a vendégforgalmat is vizsgáljuk. A szükebben vett szakmai szereplőkkel való együttműködés minden járásban, így turisztikailag frekventáltakban is erős, viszont az egyéb partnerekkel történő kooperáció mértéke jóval alacsonyabb, az adatok egymással való korrelációja közepes.

Látványos eredményeket hozhatna és minden érintett félnek elönyös lenne a szélesebb körü és tartalmasabb kapcsolatrendszer kiépítése. Erre a külföldi szakirodalom és az ott bemutatott esettanulmányok (TERLUIN 2003) is felhívják a figyelmet. A rendkívül széttagolt, sok szereplőből álló turizmus szektor sokkal hatékonyabb müködésre és nagyobb vendégforgalom generálására lenne képes az Alföldön, de egész Magyarországon is, ha az érdekeltek hathatós és valós, az ágazat harmonikus müködését elősegítő, sőt azt biztosító együttműködést tudnának megvalósítani mikro- és makro szinten egyaránt. A szálláshelyek sokkal színesebb szabadidős programkínálatot tudnának felmutatni, s ezáltal minden bizonnyal több vendégük és bevételük lenne, az egyéb partnerek pedig szintén vendéghez és egyben jövedelemhez jutnának az együttmüködések bővítése révén. Ezek révén tudná igazán kifejteni multiplikátor és térségfejlesztő hatását a turizmus. 


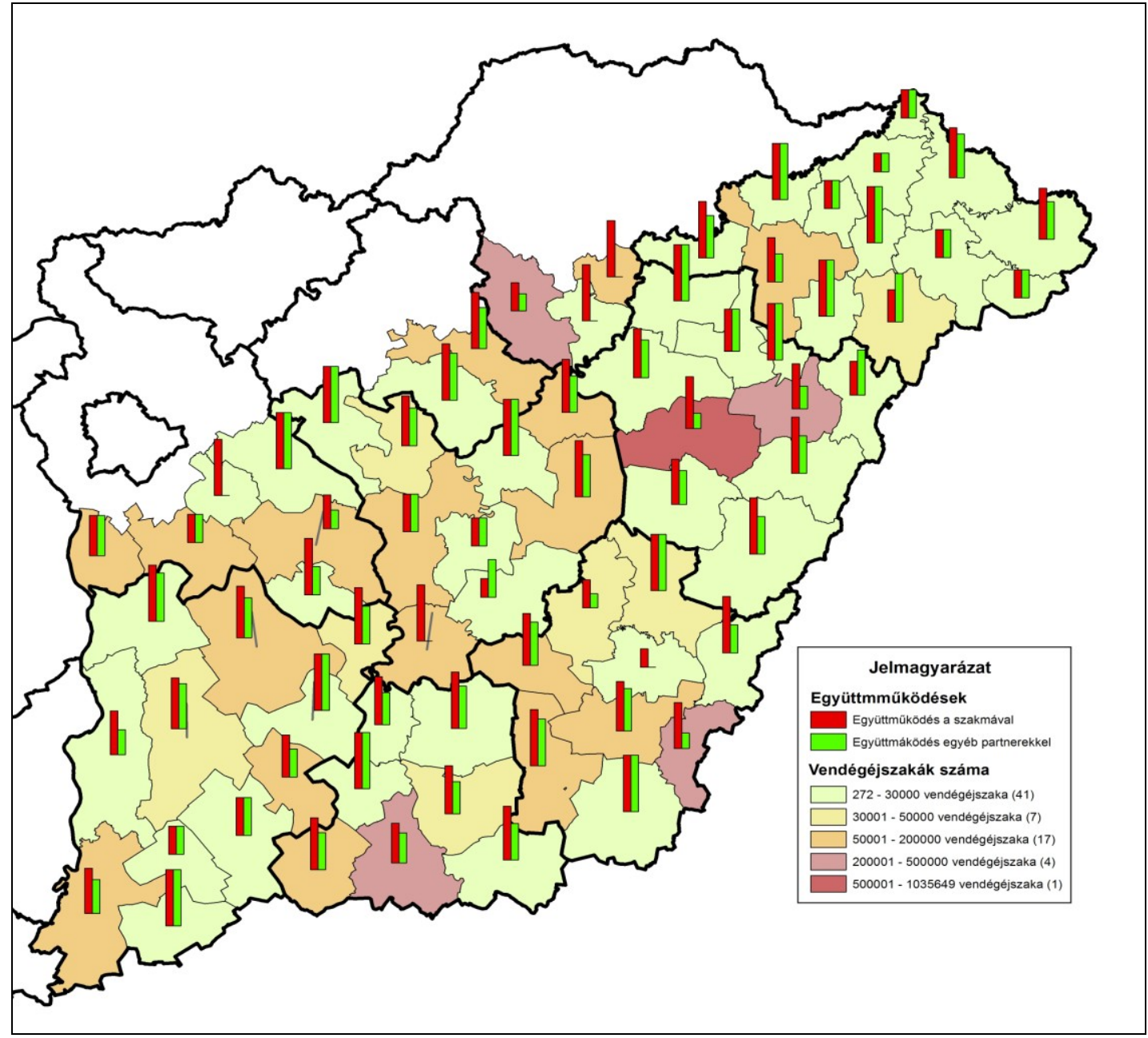

Forrás: beérkezett kérdőívek alapján saját szerkesztés

Mint korábban utaltam rá a turisztikai ágazat szereplői az Alföldön nagyon jelentős fejlesztéseket hajtottak végre az elmúlt 10 évben, és ugyanezt tervezik a következő időszakban is. A válaszadók több mint $80 \%$-a fejlesztette szolgáltatásait az elmúlt 10 évben és közel ugyanennyien tervezik ezt 5 éven belül. Ez a jövőbe vetett hitet jelzi, amit tovább erősít az is, hogy függetlenül legmagasabb iskolai végzettségétől, valamint turisztikai végzettségének meglététől, illetve hiányától, a válaszadók 90\%-a bizakodó tevékenysége jövőjét illetően. Tovább boncolgatva a jövő és a tervezett fejlesztések kérdéskörét megállapítható, hogy még a jövőt pesszimistán látók között is feltünően magas, 55\% körüli azok aránya, akik fejlesztést terveznek 5 éven belül. Ez egyfajta előremenekülést is jelez, de minden bizonnyal erősen motiválja a jövőbeli fejlesztéseket az EU-s források további megszerzésének lehetősége is. Az alföldi turisztikai szolgáltatók válaszaiból a jövőbeli fejlesztések tartalmának átstrukturálódása tünik ki. A mögöttünk hagyott években jellemző szállásférőhely bővítések a jövőben kevésbé lesznek a fejlesztések homlokterében, inkább a 
szolgáltatások minőségének javítása és a szolgáltatások körének bővítése fog megvalósulni, ami remélhetőleg az alacsony kapacitás kihasználtsági és bevételi-jövedelmezőségi mutatók javulását fogja eredményezni.

Lényeges a turizmus beágyazottsága szempontjából, hogy maguk a turisztikai szektor szereplői hogyan értékelik a turizmus jelentőségét az adott településen. A válaszadók relatív többsége (46\%-a) kiegészítő tevékenységnek tartja települése gazdaságában. Némileg kisebb részük, de összességében mégis jelentős csoportjuk (38\%) véli meghatározónak azt. Előbbi válaszokat nagy számban a csongrádi, a kiskőrösi, makói, kecskeméti és balmazújvárosi járásból küldték be, míg az utóbbiak nagy többsége nem meglepő módon az alföldi fürdővárosok járásaiból (hajdúszoboszlói, gyulai, mórahalmi, kiskunmajsai, ráckevei, tiszakécskei, mezőkövesdi, karcagi) és nagyvárosokból (Szeged, Debrecen) érkezett. Számos turisztikai szereplő vélekedik ugyanígy a tipikusan vidékies turisztikai szolgáltatásokat kínáló térségekben is (Szatmár-Bereg, Hortobágy térsége, Tiszató, valamint Szarvas-Békésszentandrás és Baja környéke). Ahogyan az várható volt dominánsnak vélik az ágazatot a település/térség gazdaságában az intenzívebb turizmussal rendelkező járásokban: Hajdúszoboszló, Gyula, Mórahalom és a Tisza-tó környékén. A kisebb léptékű vendégforgalmú járásokban (csongrádi, kiskőrösi, balmazújvárosi, fehérgyarmati, vásárosnaményi) inkább kiegészítő tevékenységnek gondolják. Mindezek mellett jóval kisebb, 15\% alatti azok aránya, akik nem tartják jelentős tevékenységnek (magas az arányuk pl. a kunszentmiklósi járásban).

Nem meglepő, hogy a tevékenységük jövőjét bizakodóan megítélők csoportja a turizmus szerepét is magasabbra értékeli településén. Nem mutatkozik viszont jelentős különbség (maximum 1-2\% pontnyi) e tekintetben a turisztikai végzettséggel rendelkezők és nem rendelkezők között.

12. táblázat: A turizmus jelentőségének megítélése a jövőbeli fejlesztések kapcsán

\begin{tabular}{|c|c|c|c|c|c|c|c|c|c|c|c|}
\hline \multirow{2}{*}{$\begin{array}{l}\text { Fejleszti } \\
\text { szolgálttatásait } \\
5 \text { éven belül } \\
\end{array}$} & \multicolumn{2}{|c|}{$\begin{array}{c}\text { Nem jelentős } \\
\text { a település } \\
\text { gazdaságá- } \\
\text { ban }\end{array}$} & \multicolumn{2}{|c|}{$\begin{array}{l}\text { Kiegészítő } \\
\text { tevékenység } \\
\text { néhány } \\
\text { család } \\
\text { számára }\end{array}$} & \multicolumn{2}{|c|}{$\begin{array}{c}\text { Kiegészítő } \\
\text { tevékeny- } \\
\text { ség sok } \\
\text { család } \\
\text { számára }\end{array}$} & \multicolumn{2}{|c|}{$\begin{array}{l}\text { Meghatározó a } \\
\text { település } \\
\text { gazdaságában }\end{array}$} & \multicolumn{2}{|c|}{$\begin{array}{l}\text { Nincs } \\
\text { válasz }\end{array}$} & \multirow{2}{*}{\begin{tabular}{|r|}
$\begin{array}{l}\text { Összes } \\
\text { en }\end{array}$ \\
\\
\\
388 \\
\end{tabular}} \\
\hline & 53 & $13,66 \%$ & 109 & $28,09 \%$ & 72 & $18,56 \%$ & 148 & $38,14 \%$ & 6 & $1,55 \%$ & \\
\hline $\begin{array}{l}\text { Nem fejleszti } \\
\text { szolgáltatásait } \\
5 \text { éven belül }\end{array}$ & 16 & $16,67 \%$ & 23 & $23,96 \%$ & 21 & $21,88 \%$ & 35 & $36,46 \%$ & 1 & $1,04 \%$ & 96 \\
\hline Összesen & 69 & $14,26 \%$ & 132 & $27,27 \%$ & 93 & $19,21 \%$ & 183 & $37,81 \%$ & 7 & $1,45 \%$ & 484 \\
\hline
\end{tabular}

Forrás: beérkezett kérdőívek alapján saját szerkesztés 
6.5.2. A turizmus jellemzői a falusi vendégfogadók szerint

A turisztikai szektor karakteres csoportját képezik az Alföldön a falusi szállásadók. Jóllehet számuk a vonatkozó jogszabály és a statisztikai adatgyüjtés változása miatt abszolút értékben jelentősen csökkent 2010-től, ám - mint korábban utaltam rá tevékenységüket más ,jogi-statisztikai” kategóriában minden bizonnyal továbbra is végzik, és vidéki területek turizmusának továbbra is meghatározó szereplői.

A primer kutatásom során beérkezett kérdőívek kitöltőinek legnagyobb létszámú csoportját ezen szállásadói csoport képezte. Többségében kvalifikált, közel 65\%-ban felsőfokú végzettségü, 50\%-ban turisztikai végzettséggel is rendelkező szállásadó válaszolt. 75\%-uk OKJ-s turisztikai végzettséggel bír. 60\%-uk idegen nyelvet is beszél. Legnagyobb arányban német és angol alapfokú nyelvismerettel rendelkeznek.

Sokatmondó információkkal szolgálnak a falusi turisztikai szolgáltatás indításának okai, hiszen a tevékenység elkezdésének indítékai akár a későbbi működés minőségére is hatással lehetnek. A válaszadók három szempont mentén adtak értékelést a kérdőívben. Ezek közül legjelentősebb súllyal a kiegészítő jövedelemszerzés lehetősége szerepelt. Kisebb mértékben ugyan, de mégis szerepet játszott a tevékenység elindításában a vendéglátáshoz szükséges feltételek megléte, legtöbbször egy vidéki környezetben birtokolt ingatlan. Szerencsés módon nem magas a kényszerüség szerepe, amely pl. munkanélküli státuszból vagy más lehetőségek hiányából adódhatott.

\section{7. ábra: A falusi szállásadói szolgáltatás elindításának indítékai}

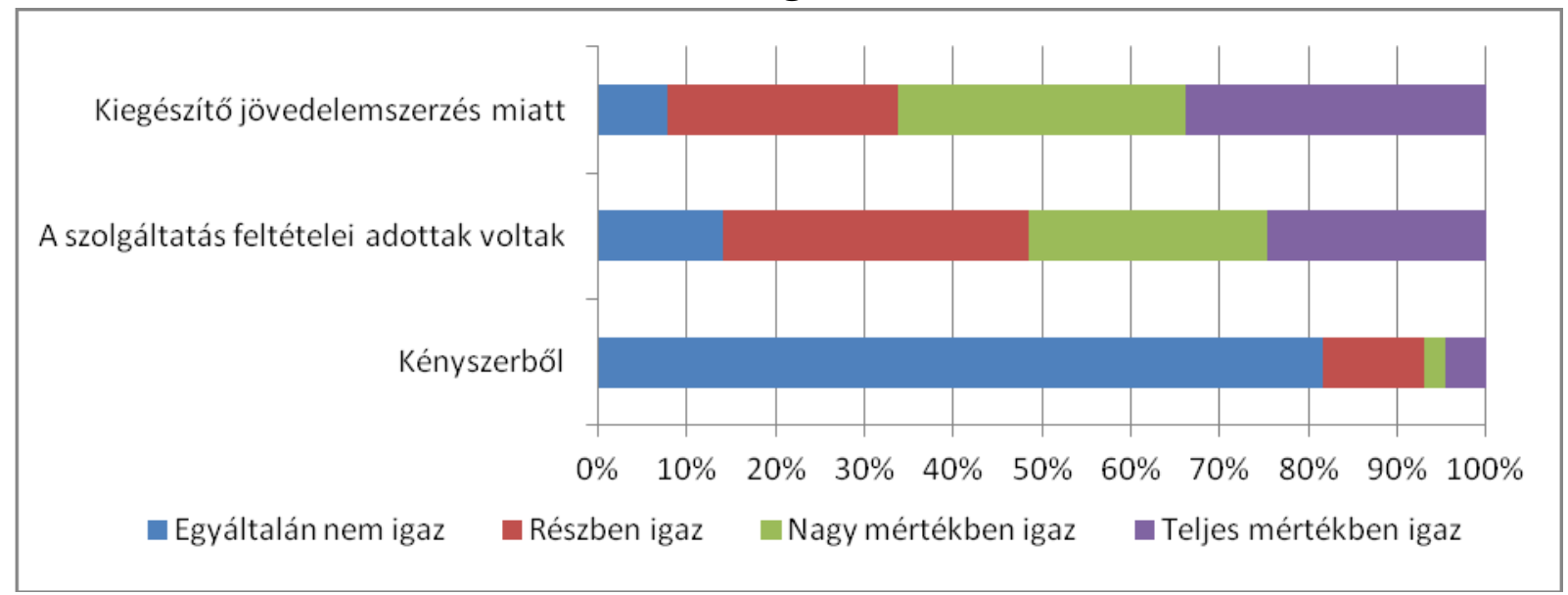

Forrás: beérkezett kérdőívek alapján saját szerkesztés 
A falusi szálláshelyek típusát tekintve a szállásadók több mint 4/5-e vendégházat üzemeltet, a vendégszoba, lakrész és sátorozóhely együttesen 15\%-ot tesz ki. A legtöbben magas minőségi kategóriát képviselő (2/3 részben 4 napraforgós) szálláshelyeket müködtetnek, melyek 30\%-a szakosodással is rendelkezik. A speciális szolgáltatások alapján elnyerhető szakosodások közül legnagyobb számban az „Aktív üdülés falusi portán”, az „Üdülés lovas tanyán” és „Hagyományok portája” fordult elő, de valamennyi típus megjelent kérdőívet kitöltők között. Fontos kitérni arra, hogy újszerü és speciális szolgáltatásokat kínáló vendégfogadók is jelen vannak az Alföldön, így a „Bioporta/Ökoporta”, a „Kerekes székes és mozgáskorlátozottakat fogadó vendégház” és a „Falusi életmód ifjúsági porta” egyaránt megtalálható.

Nem jellemző ma már a falusi turizmus rendszerváltáskori újraindulása után még elterjedt vendégfogadási mód, mely szerint a vendégfogadó egy fedél alatt lakik a turistával. A beérkezett kérdőívek alapján ez az elszállásolási forma a vendéglátók kevesebb mint 1/4-nél fordul elő. Ahol jellemző ott is a minőségi kategóriák emelkedésével egyre csökken az arányuk. A 2 és 3 napraforgós szállások 1/3-ánál fordul elö, de a 4 napraforgósoknál már 15\%-ot alig meghaladó a részesedésük.

A szállásadók saját maguk által kínált szolgáltatásai igen széles skálán mozognak a kulináris élményektől kezdve az aktív kikapcsolódáson át (lovas programok, kerékpározás, horgászat, stb.) a hagyományos gazdálkodáshoz köthető programokig. A legtöbb szállásadónál azonban inkább a kisebb hozzáadott értékü, kevésbé helyspecifikus (,alföldies”) szolgáltatástípusok jellemzőek. A válaszadó vendégfogadók több mint felénél van lehetőség szabadtéri sütés-fözés, sporteszközök-játékok, játszóudvar, kerékpárkölcsönzés igénybevételére. Az igazán izgalmas, az alföldi vendégfogadás specifikumait jelentő szolgáltatások (lovas programok, hagyományos gazdálkodás bemutatása, kézműves programok, vidéki élethez kapcsolódó tevékenységek) még kevésbé jellemzőek (a válaszadók 20-35\%-ánál), pedig ez tenné igazán unikálissá, sehol máshol meg nem ismételhetővé a szolgáltatók kínálatát, ez jelenthetné az alföldi vidékies turisztikai szolgáltatások USP-jét (Unique Selling Proposition).

Árnyaltabbá és kedvezőbbé teszi viszont a képet, hogy szinte minden vendégfogadó (9/10-ük) kínál olyan programokat, amelyeket más szolgáltatónál lehet igénybe venni. Kimondottan ilyen szolgáltatás a fentiekben hiányoltak egy része, közte a lovas és kézműves programok, az állatsimogató, de ezek közé tartozik a szakképzett túravezetés és a horgászat is. 
Összefügg mindezekkel, hogy a nyilatkozó vendégfogadók 3/4-e nem életvitelszerűen, fóállásban végzi tevékenységét. Szinte ugyanennyien értékelték a turizmust településük életében kiegészítő és nem jelentős tevékenységnek.

Nem mutat viszont jelentős összefüggést a falusi turisztikai és a mezőgazdasági tevékenység. A turisztikai szolgáltatások mellett a választ beküldő szállásadók mindössze 1/4-e folytat gazdálkodói tevékenységet valamilyen formában (pl. őstermelőként vagy vállalkozóként). Ez lényegében megegyezik az országos adattal (21\%). Legjellemzőbb, hogy a vendégfogadó a szolgáltatási ágazat valamely szegmensében alkalmazottként dolgozik. S mint a fentiekben bemutattam a megkérdezettek 2/3-a úgy nyilatkozott, hogy nagymértékben vagy teljes mértékben a kiegészítő jövedelemszerzés lehetősége miatt kezdte el ezt a tevékenységét. Ezek magyarázatot is adnak arra a korábbiakban szintén feltárt tényre, hogy a szállásadók saját szolgáltatásként inkább alacsonyabb hozzáadott értékü programokat kínálnak. Mivel zömmel nem életvitelszerüen végzik turisztikai szolgáltatói tevékenységüket, így föállás mellett kevesebb időt tudnak arra fordítani. Ebböl következően inkább olyan szolgáltatásokat kínálnak, amelyekhez saját humán erőforrásaik kevésbé szükségesek.

A belső erőforrások fontosságát a falusi szállásadók több ponton máshogy ítélik meg, mint az összes válaszadó. A három általuk legfontosabbnak ítélt tényező esetükben is természethez kötődik, de sorrendjük eltér a teljes minta által kialakított véleménytől. Szembetűnő, hogy a felszíni és felszín alatti vizek jelentőségét alacsonyabbra értékelik a falusi szállások üzemeltetői, és azok sorrendben csak a harmadik helyre kerültek. Az első helyet fogalja el viszont ezen válaszadói csoportnál a „Tájkép, természetvédelmi területek” kategória. Előzetesen várható volt, hogy nagy fontosságúnak értékelik a termőföldet és a vidéki életmódot. A „Mezőgazdaság, helyi élelmiszerek”, „Helyi identitás” és a „Kulturális örökség, hagyományok” ezen válaszadói csoportnál is az élmezőnyben kaptak helyet, de azokat összes válaszadó véleményéhez képest alacsonyabb fontosságúnak vélik. A rendezvények, fesztiválok vonatkozásában mutatkozik az egyik legjelentősebb eltérés. A falusi szállásadók szerint jóval kevésbé jelentős belső erőforrást jelentenek, mint az összes turizmusban érdekelt válaszadó körében. Ahogy előzetesen várható volt a falusi szolgáltatókra szükített válaszadói célcsoport esetén erőteljesebben kirajzolódnak a kifejezetten vidékiesnek tekinthető belső erőforrások. 


\section{8. ábra: Az Alföld belső erőforrásai a falusi szállásadók szerint}

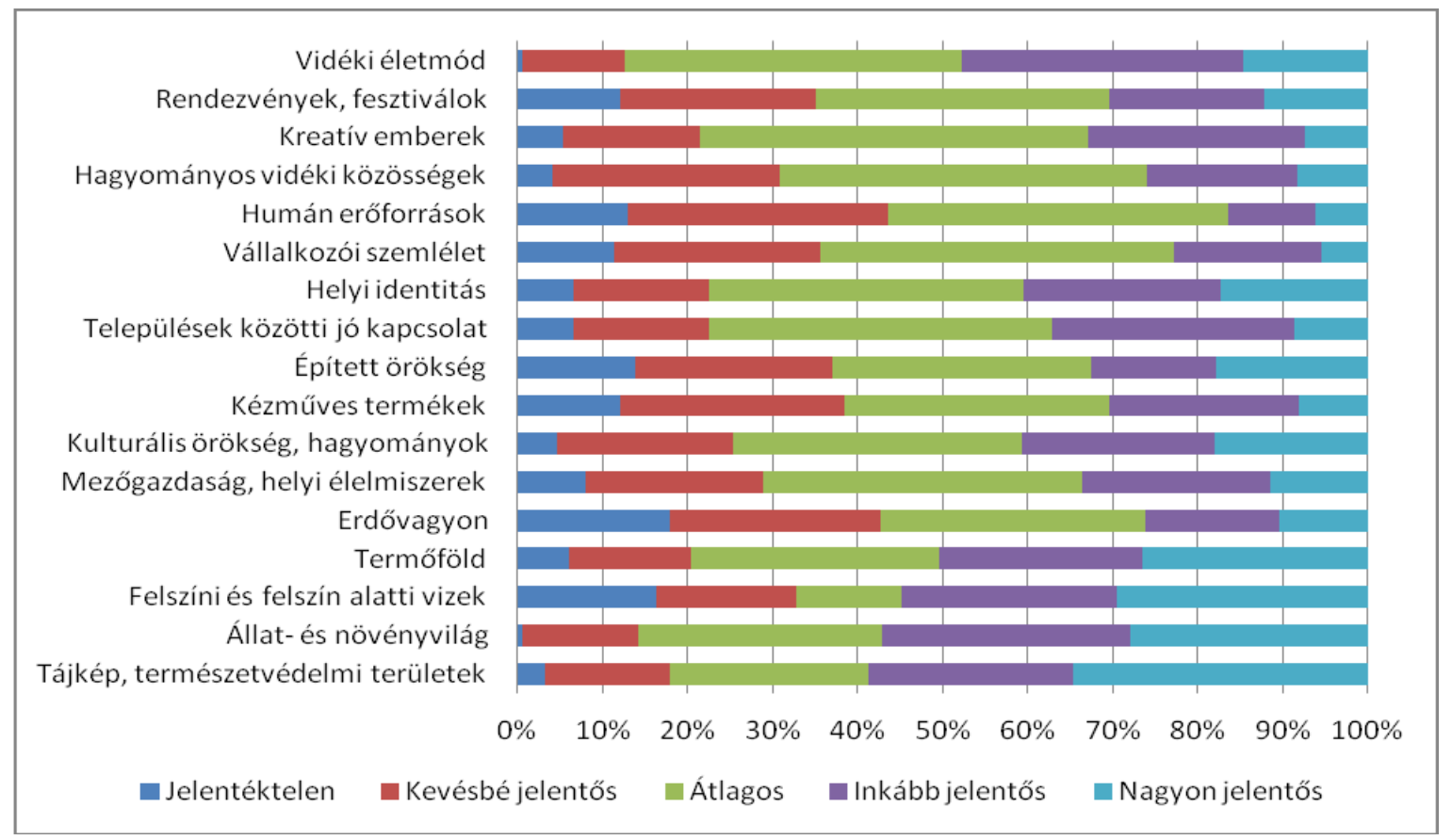

Forrás: a beérkezett kérdőívek alapján saját szerkesztés

A falusi szállásadók ugyanolyan arányban müködnek együtt az ágazat többi szereplőjével, mint az összes válaszadó, azonban a pozitívabb annak tartalma. Majdnem 4\% ponttal többen értékelik erősnek és csaknem $6 \%$ ponttal kevesebben átlagosnak a kooperációt. Minden bizonnyal ez a szolgáltatói csoport jobban ráutalt a többi szereplöre, $\mathrm{s}$ csak egymást segítve tudnak müködni, illetve a kisebb településméret miatt jobban ismerik egymást az érdekelt felek és nagyobb a bizalom is egymás iránt. Még érezhetőbb a kooperációban pozitív irányban megmutatkozó eltérés a turizmus szektorhoz kapcsolódó egyéb szolgáltatókkal fenntartott kapcsolatok terén. Több mint 14\% ponttal nagyobb az együttmüködők aránya, illetve a kapcsolatot átlagosnak minősítők aránya több mint 7\% ponttal alacsonyabb.

\section{9. ábra: A turisztikai együttmüködések minősége az Alföldön}

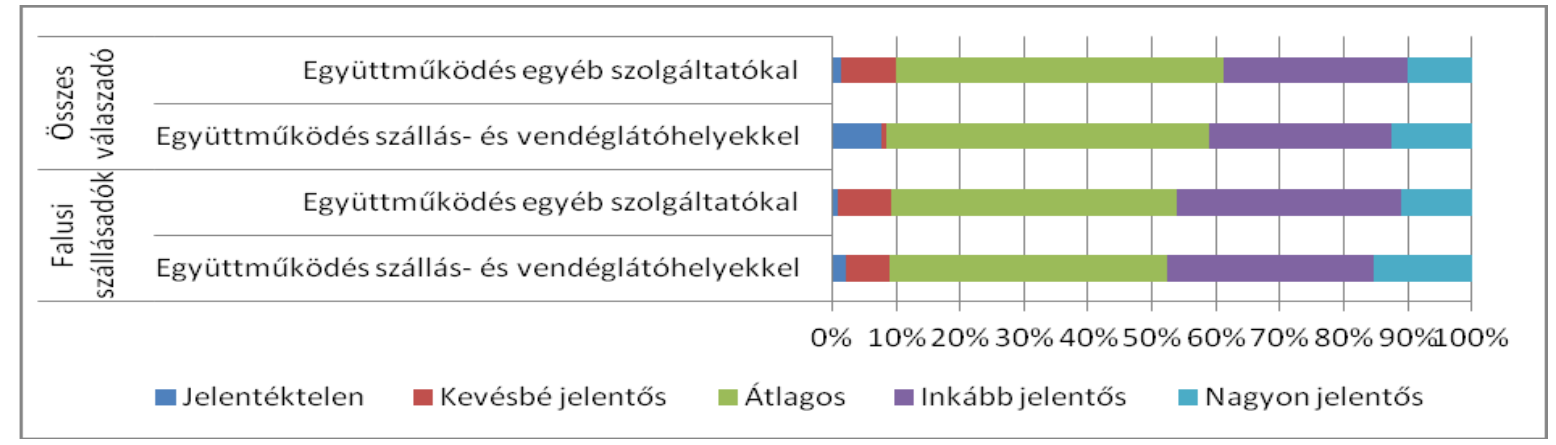

Forrás: beérkezett kérdőívek alapján saját szerkesztés 
A közös munkát jelentősnek és nagyon jelentősnek tartók aránya $40 \%$ feletti. A felsőfokú végzettségüeknél átlag feletti, a középfokú végzettséggel rendelkezők esetén átlag alatti ennek aránya.

Csak a válaszadók 35\%-a tagja LEADER helyi akciócsoportnak. Ez megítélésem szerint igen alacsony arány, s azért is kevés, mert ez a tagság egyfajta tanuló vagy továbbfejlesztő terepe lehetne a közös gondolkodásnak, a lokális együttmüködések elmélyítésének. A helyi közösségek számára mód nyílna saját fejlesztési stratégiájuk közös megalkotására és megvalósítására. Ha egy-egy cég, civil szervezet vagy magánszemély nem tagja ilyen közösségnek, jóval korlátozottabb beleszólása lehet mindezek kimunkálásába, és végső soron saját fejlesztési elképzeléseik formálásába, legalábbis a LEADER elv szerint.

A teljes válaszadó sokaság 4/5-e, a falusi szállásadóknak pedig még nagyobb része (87\%) fejlesztette szolgáltatásait az elmúlt évtizedben, és több mint $80 \%$-uk tervezi azt a következő 5 évben is, ami mindenképpen a jövőbe vetett bizalomra utal. Még nagyobb arányt (90\%) képviselnek azok, akik bizakodóak tevékenységük jövőjét illetően.

A falusi szállásadók érzékelhetően másképp értékelik a turizmus jelentőségét településükön, mint az összes válaszadó. Ez a csoport döntően kiegészítő tevékenységnek tartja, mely csak néhány családnak nyújt megélhetést. (Ezzel kapcsolatba hozhatók a tevékenység elindításának indokaként megjelölt tényezők: a kiegészítő jövedelemszerzés és a szolgáltatás feltételeinek megléte.) Jelentősen kisebb, de mégis számottevőnek nevezhető körükben azok csoportja (24\%), akik meghatározónak tartják az ágazatot a település gazdaságában. Szembetűnő, hogy nincs olyan járás az Alföldön, ahol a válaszadók többsége a turizmust véli meghatározónak a helyi gazdaságban. Néhány járásban, a falusi turizmus magterületein (fehérgyarmati, vásárosnaményi, tiszafüredi, kecskeméti) kiegyenlített az arány. Szakmai tapasztalataim és a kérdőívekre adott válaszok egybevágnak abban a vonatkozásban, hogy a jelenleg falusi turizmus egy viszonylag szűk csoport, településenként néhány család számára kínál biztos vagy kiegészítő megélhetést azokon a településeken, ahol egyáltalán jelen van. 
30. ábra: A turizmus jelentősége föbb válaszadói csoportonként

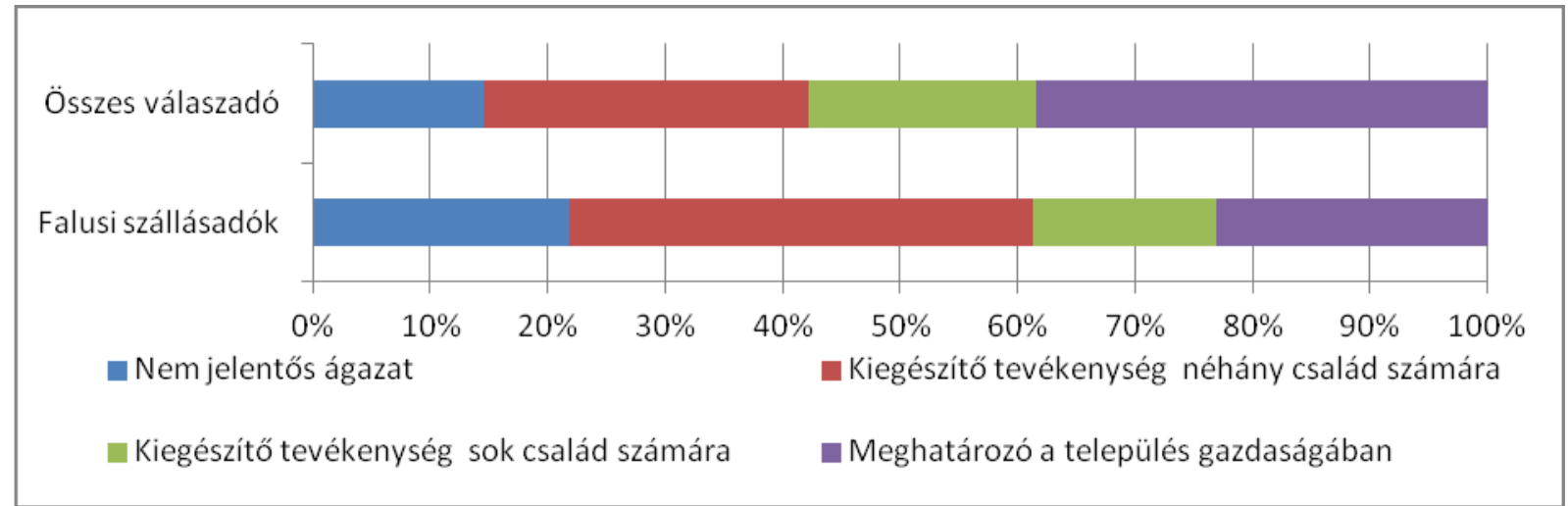

Forrás: beérkezett kérdőívek alapján saját szerkesztés

6.5.3. Az alföldi vidékturizmus kiemelt térségeinek sajátosságai a kérdőívek alapján

Az Alföld attrakcióinak, vonzerőinek, valamint a térség turizmusát kvantitatív módon leíró adatainak elemzése során jól kirajzolódtak azok területi egységek, magterületek, ahol a leginkább jellemző jelenségnek értékelhető az Alföldön a turizmus. Elég nagy biztonsággal körülhatárolhatók azok a területek, ahol kifejezetten vidékies vonzerök, szolgáltatások és kínálat várja a vendégeket. Sajátosak, illetve meghatározhatók a városi turisztikai szolgáltatások felé átmenetet mutató „köztes” térségek is.

A következőkben néhány ilyen tipikus térségből (Szatmár-Bereg; Tisza-tó térsége és Hortobágy; Mórahalom és Kiskunmajsa környéke; továbbá Kecskemét, Gyula és Hajdúszoboszló térsége), illetve az általuk lefedett járásokból beérkezett valamennyi válasz elemzését mutatom be.

A Duna-Tisza-közi Homokhátság területén lévő mórahalmi és kiskunmajsai járás már természeti földrajzi adottságait (magas napsütéses órák száma, sajátos homok talajok, tanyás-kertes, illetve nemzeti parki területek) tekintve is egyedi színfoltját képezi az Alföldnek. Tipikus vidéki járások ezek, de a turizmus nagyságrendje és intenzitása már lassan-lassan eléri azt a szintet, ami a vidéki területekre általában jellemző. A turisztikai ágazat megjelenése és bizonyos térhódítása az utóbbi 2-3 évtizedben vált jellemzővé ezen a vidéken. Mindkét járásban egyértelmüen a termál- és gyógyvizek, valamint az ezekre épült fürdők a legerősebb vonzerők, jóllehet Mórahalom városa az utóbbi két évtized példaértéküen tudatos és nagyon szisztematikus turizmusfejlesztése révén egyre diverzifikáltabb termékkínálatot tud felmutatni. Az ezen járásokból visszaküldött több mint 
30 kérdőív a szolgáltatók igen magas aktivitását mutatja. A válaszok alapján a belső erőforrásokról kialakuló kép kiegyenlített. Érdekes, hogy a helyi identitáson kívül nem jelöltek meg kiugróan magasra értékelt tényezőt. Egyaránt $50 \%$ felett vélik jelentősnek a természeti értékeket, közte a felszín alatti vizeket, a mezőgazdasághoz köthető erőforrásokat és a humán tényezőket. Egyedül az épített örökség jelentőségét vélik alacsonynak a turizmusban érdekelt válaszadók. Az együttmüködési hajlandóságuk a szektoron valamennyi szereplője között átlag feletti. Ez szinte nem is lehet másként, hiszen Mórahalom városában TDM szervezet is müködik, amelyben ez alapkövetelmény. A turizmust nagyon jelentős ágazatnak tartják a település gazdaságában is. Csaknem 60\% azok aránya, akik meghatározónak, további $20 \%$ feletti arányban pedig sok család számára fontos jövedelmet biztosító tevékenységnek vélik. A jövőben is jó eséllyel így marad ez, hiszen a válaszadók több mint $80 \%$-a fejleszteni szeretne a következő 5 évben és $95 \%$-uk bizakodó vendéglátó tevékenysége jövőjét illetően.

A Tisza-tó térsége az Alföld turizmusának valóban fontos és üde színfoltja. A mesterséges tó létrejötte előtt súlyos gondokkal küzdő, belső perifériának számító térség néhány településének gazdasági-társadalmi életébe új vitalitást hozott a turizmus megjelenése, amit a kérdőívek is alátámasztanak. A vonzerőket bemutató fejezetben már ismertetettem, hogy a Tiszához kapcsolódó vízi élővilág és természeti értékekre alapozva napjainkra hazánk egyik kiemelkedő ökoturisztikai célterületévé vált e terület, amit egy részének világörökségi státusza és az EDEN (Európai Kiváló Desztinációk) versenyfelhíváson való sikeres szereplése is jelez. A vízi-vízparti turizmus természetesen kiemelkedő vonzerőt jelent. A Tisza-tó térségét „klasszikusan” vidékies járások alkotják, azonban a turizmus bizonyos elemei (pl. nyári intenzív vízparti üdülések) - Lane beosztása szerint - már inkább a vidéki és városi típusú üdülések közötti átmeneti kategóriába tartoznak. Mindezek nagyon eklatánsan megmutatkoznak a térség 4 járásából (tiszafüredi, kunhegyesi, füzesabonyi és hevesi) visszaérkezett több mint 30 kérdőív belső erőforrásokra vonatkozó értékeléseiből is. Kiemelkedően magas, 70-90\%-os jelentőséget tulajdonítanak ugyanis a válaszadók a természethez köthető erőforrásoknak. 50\% körüli a rendezvényeket, fesztiválokat, valamint a vidéki életmódot inkább jelentősnek vagy nagyon jelentősnek jelzők aránya. A többi, kérdőívben szereplő tényező ezektől messze elmaradva, a 30\% alatti értékelést kapott. A turizmus szereplői közötti együttmüködés itt is messze átlag feletti, sőt az együttmüködés minőségét is kifejezetten pozitívan értékelték a válaszadók. Nem meglepetés tehát, hogy a turizmus szerepét szintén magasan átlag felettinek tartják a 
településük gazdaságában. A jövőbe vetett bizalmi indexük 87\%-os, a turisztikai végzettségüeké még ettől is magasabb, meghaladja a 94\%-ot.

A közeli Hortobágy az Alföld, magyar puszta és a pásztorélettel összefüggő hagyományok régóta legismertebb térsége. Természeti és kulturális öröksége révén méltán került fel az UNESCO világörökségi listára. Vidékies járások (balmazújvárosi, hajdúböszörményi, hajdúnánási) alkotják, jellemzően vidékies kínálattal. Belső erőforrásainak jelentőség szerinti értékelése a vendégfogadók és az ágazat többi szereplője szerint, de a külső kutató-elemző szemével is egybeesik. A beérkezett 23 kérdőív alapján a természetvédelmi területek és a kulturális örökség, valamint a hagyományok dominanciája emelkedik ki. A turizmus szereplőinek együttmüködése itt csak áltagos szintü, kimutathatóan gyengébb annak minősége más térségekhez képest. A szűkebben vett turisztikai szakmával és a tágabb szolgáltatói körrel a válaszadók több mint fele maximum átlagosnak véli a kooperációt. Az öt éven belül megvalósuló fejlesztések és a tevékenység jövője iránti bizakodás átlagos. A Hortobágy térségében, az egyik legnagyobb hagyományokkal bíró vidéki turisztikai célterületen a társadalmi erőforrások várttól elmaradó szintje meglepő.

Az utóbbi 25 évben Szatmár-Bereg térségében, a tisztán vidékies fehérgyarmati és vásárosnaményi járásban fejlődött ki talán a legtisztább formában a falusi-vidéki vendégfogadás. Tulajdonképpen más alapja nem volt ennek, mint az emberkéz által kevésbé átalakított természeti környezet, a szakrális emlékekhez kötődő épített örökség és a néprajzi értékeket képviselő hagyományok. Ebből nagy szorgalommal és szervezőmunkával fejlesztették ki a térség sajátosságait bemutató turisztikai szolgáltatásokat. Jóllehet a falusi vendégfogadás a számszerüsített adatokat tekintve szebb napokat is megélt e vidéken még mindig az Alföld egyik legkeresettebb és legautentikusabb vidékturisztikai területe a fehérgyarmati és a vásárosnaményi járás. A fentiekben említett erőforrások a turizmusban érdekeltek által visszaküldött 20 kérdőív alapján is meghatározó jelentőségűek, ugyanígy a „puha tényezők” közül a vidéki életmód is, egyedül csak a gasztronómiához, helyi élelmiszerekhez és a rendezvényekhez kötődő erőforrások kaptak alacsonyabb értékelést. Bőven 50\% feletti arányban vélik ezeket is jelentősnek vagy meghatározónak, de elmaradnak a természet alkotta erőforrások $80 \%$-ot elérő mutatóitól. A turizmus szereplöi itt is átlag fölötti együttmüködési hajlandóságról nyilatkoztak. Nagyon magas a jövőben fejlesztést tervezők aránya (85\%) és kiemelkedő a tevékenységük jövőjébe vetett bizalmuk (95\%). 
Speciális helyzetben van a Duna-Tisza-közi Homokhátság centrumában Kecskemét és térsége. Maga város az ország egyik dinamikusan fejlődő megyeszékhelye, a járás többi települése azonban sajátos vidékies jegyeket mutat. A központi város meghatározó szerepe miatt a járás egésze is városinak tekinthető, de a kettősség turisztikai kínálatában is erősen megmutatkozik. Ez kiviláglik a beérkezett kérdőívek belső erőforrásokra vonatkozó értékelései alapján is. Nincs 2-3 annyira kiugróan jelentősnek értékelt tényező, mint az eddigiekben bemutatott járások többségénél. A város erős hatása mutatkozik meg abban, hogy a kulturális örökséget értékelték legfontosabb eröforrásnak a válaszadók, ugyanakkor a vidékiséget jelzi, hogy második helyen a mezőgazdasághoz kapcsolódó értékeket és a helyi termékeket említették. Ugyancsak a vidékies jellegre utal a természeti értékek kedvező helyezése. A hagyományosan alföldi „város és vidéke” kapcsolat tehát itt Kiskunságban a turizmus terén is megmutatkozik. A turisztikai együttmüködések terén mutatkozó, előzetesen körvonalazható képet teljesen igazolják a válaszok. A magas együttmüködési hajlandóság mellett az érdekeltek fele viszont csak átlagosnak ítéli a kapcsolatokat. A turizmust, ha nem is meghatározó, de jelentős ágazatnak tartják, $60 \%$-uk sok család számára kiegészítő jövedelmet nyújtó ágazatnak, vagy meghatározónak véli az adott település életében. A tervezett fejlesztések és a tevékenység jövőjébe vetett bizalom szinte azonos, $83 \%$ körüli értékeket mutat.

Külön ki kell térni az alföldi turizmus két sajátos „fellegvárára” Hajdúszoboszlóra és Gyulára. A térségtipizálások alapján mindkét járás vidékies, de turisztikai kínálatuk inkább a köztes kategóriába tartozik, sőt bizonyos tekintetben városias jegyeket mutat. Sok a hasonlóság a két térség turisztikai kínálata és fogadóképessége között, de talán még több a különbség. Egyrészt Hajdúszoboszló vendégforgalma két és félszerese a gyulainak, másrészt a hajdúszoboszlói járás egyértelműen és kizárólag a termálvízre és az arra épülő fürdőkomplexumra építhet, legfeljebb a szomszédos nagyváros, Debrecen oldja ezt a túlsúlyt, addig Gyulán a termáladottságok mellett történelmi, kulturális örökség is meghatározó vonzó tényező. Ez tökéletesen igazolódik a kérdőívekből, sőt az is kiolvasható meglepő módon, hogy Gyulán a válaszadók nem a termál-gyógyvizet tartják a legjelentősebb belső erőforrásnak, hanem inkább az épített, valamint a kulturális örökséget. Mindkét térségben fontosnak, sőt meghatározónak ítélik a rendezvényeket és fesztiválokat. Érdekes, de a helyi viszonyokra való némi rálátás alapján mégsem teljesen meglepő, hogy Gyulán a válaszok alapján sokkal erősebbre értékelhető a helyi identitás, mint Hajdúszoboszlón. A szűkebben vett szakmai szereplőkkel mindkét járásban erőteljes az együttmüködés (80-90\% közötti), de a tágabb értelemben vett szakmai szereplőkkel 
egyáltalán nem jellemző (70\% feletti arányban nem). Lényeges különbség a két járás szolgáltatói között, hogy míg a hajdúszoboszlói turisztikai szereplök fele jellemzően átlagosnak tartják a más szolgáltatókkal való együttmüködést, addig Gyulán a válaszadók 55\%-a jelentősnek vagy nagyon jelentősnek véli. Mindkét térségben 70\% feletti azok aránya, akik meghatározónak nevezték a turizmust a helyi gazdaságban. A turizmus jövője szempontjából bíztató, hogy a szakmájuk jövőjében bizakodók aránya mindkét esetben $80 \%$ feletti, és több mint 75\%-uk fejlesztést is megvalósít 5 éven belül. Ezek az arányok alacsonyabbak mint a tipikus vidékturisztikai térségekben.

Összegzésként kiemelhető, hogy válaszadói csoportonként, illetve térségenként sok tekintetben differenciált vélemények, attitüdök szürhetők le a kérdőívekre adott válaszokból, melyek hozzájárulhatnak az Alföld turizmusáról alkotott pontosabb kép kialakításához. 


\subsection{A vidékturizmus alföldi sajátosságainak megjelenése turisztikai témájú weboldalakon}

Korunkban a kommunikáció és az információáramlás fő eszközévé az internet vált, különösen igaz ez a turisztikai szektorra, ahol az utazási döntések meghozatalában egyre nő a világhálón gyüjtött információk szerepe. Napjainkra a „hagyományos” internetes tartalmak (pl. weblapok) mellett a Web 2.0 (social media) is egyre fontosabb szerepet tölt be az információk közvetítésében. Jelentős tartalmi különbség van azonban az internetes tartalmak két generációja között. Míg a weboldalak/honlapok esetén annak tulajdonosa (müködtetője) közöl információt magáról, addig a közösségi médiában maguk a felhasználók alakítanak ki és osztanak meg tartalmakat.

Az alföldi turisztikai szektor müködése szempontjából fontos információkkal szolgál interneten történő megjelenéseik vizsgálata. Kutatásaim keretében ennek tartalmi és minőségi jellemzőit is megvizsgáltam. Áttekintettem és értékeltem, hogy megjelennek-e, s ha igen hogyan a vidékturizmus sajátos jegyei, speciális alföldi szolgáltatások és a vidékiség a turizmust müködtető szakmai szereplők internetes kommunikációjában, illetve milyen a honlapok minősége, közvetítik-e mindezeket a felhasználók felé. Emellett módom nyílt arra is, hogy a kínált szolgáltatások jellegét, sajátos vidékiségét, alföldiségét összevessem a kérdőíves már feltárt eredményeivel.

Munkám során a fenti célcsoport honlapjainak elemzésére koncentráltam, mivel a vizsgálati szempontjaimhoz szükséges információk ezen „hagyományos” internetes tartalmakon érhetők el. A közösségi médiában történő megjelenések egyrészt céljaim eléréséhez kevéssé releváns információkkal szolgálnak, másrészt jelentős szubjektív tényezőket is tartalmaznak, így azok elemzésétől eltekintettem.

Összesen 294 alföldi turisztikai szolgáltató (123 falusi szálláshely, 46 egyéb szálláshely, 69 kereskedelmi szálláshely) és 58 egyéb turisztikai programszervező szolgáltató (pl. fürdö, lovas tanya, csárda, kikötő, egyéb programszervező, stb.) honlapját tekintettem át, továbbá a vizsgált 70 járás térségi szintű interneten történő megjelenését vizsgáltam meg az alábbi szempontok mentén.

Szálláshelyek és egyéb szolgáltatók, programszervezők esetén:

- A kínált szolgáltatások egyedisége, vidékisége ,alföldisége”

- Az objektum külső megjelenése, speciális alföldi építészeti jegyek megjelenése 
- Együttmüködés más szolgáltatókkal

- A honlapon közölt információk frissessége

- Összbenyomás a honlapról: földrajzi jellegü tartalom, tetszetősség, ötletesség, rendezettség

Turisztikai desztinációkat bemutató megjelenések esetén:

- A kínált szolgáltatások egyedisége, vidékisége „alföldi jellege”

- A honlap komplexitása: a térség kínálatának komplex bemutatása

- Konkrét csomagajánlatok szerepeltetése

- A honlapon közölt információk frissessége

- Összbenyomás a honlapról: földrajzi tartalom, tetszetősség, ötletesség, rendezettség

A honlapokat ezen szempontok szerint 10-es skálán pontoztam, majd objektumonként és szolgáltatói típusonként összesítettem a kapott értékeket.

$\mathrm{Az}$ eredmények részletes bemutatása elött érdemes azonban górcső alá venni, hogy egyáltalán milyen arányban van jelen az alföldi turisztikai szektor interneten saját, önálló honlappal. A szolgáltatói adatbázisok áttekintése nyomán megállapítható, hogy napjainkban egyáltalán nem teljes körü a vizsgálatba bevont célcsoportok világhálón való jelenléte, és egyes csoportjaik mentén is vannak eltérések. A FATOSZ adatai szerint a falusi szálláshelyeknek országosan mindössze 55\%-a, az Alföldön pedig csak 45\%-a müködtet önálló weboldalt. A social media-ban (pl. a Facebook-on) való jelenlétük becslésem szerint ettől némileg elmarad, országosan 35-40\%-os, alföldi szinten 30\%-nyi. Az egyéb (korábban magán) szálláshelyek önálló internetes megjelenési aránya kisebb, mint a falusi vendéglátóké. A különböző szálláshely foglalásra alkalmas weboldalakon és a közösségi médiában való megjelenésük viszont erőteljesebb. Az interneten való jelenlét ezen formái akár hatékonyan szolgálhatják a szállásférőhelyek értékesítését, azonban - főleg a szállásfoglalásra specializálódott weboldalak esetén - meglehetősen limitált és sablonos felületet biztosítanak, ami pont az egyediség, a vidékies elemek és az alföldiség bemutatását gátolja. Az egyedi kínálati elemek, a speciális szolgáltatások megismertetéséhez mindenképpen szükség lenne egy gazdagon illusztrált, ötletes, mindig naprakész, grafikai megoldásaiban is a vidékiséget és az alföldiséget tükröző honlap. Emellett persze az interneten való jelenlét már említett többi formája is segítheti a kínált szolgáltatások megismertetését és értékesítését. 


\subsubsection{A turisztikai szektort müködtető szereplők honlapjainak jellemzői}

Egy-egy turisztikai vállalkozás vagy objektum méretének növekedésével egyre jellemzőbb az interneten történő megjelenés valamely fentebb említett formája. A rendszerint cégek által üzemeltetett kereskedelmi szálláshelyek esetén az általában egyéni vállalkozóként vagy magánszemélyként müködtetett falusi és egyéb szállásokat jóval meghaladó, közel teljes körü a világhálón történő jelenlét. E két nagy csoport között helyezkedik el az egyéb turisztikai szolgáltatók, programszervezők köre.

A weboldalak áttekintése során az egyik legfontosabb szempont a turisztikai szektor szereplői által kínált szolgáltatások egyediségének, vidékiségének és „,alföldiségének” vizsgálata volt, melyet a turisztikai szereplők főbb csoportjai szerint mutatok be. Ezt a feldolgozási módot a további szempontok értékelése során is követem.

A mintámban legnagyobb hányadot képviselő falusi szállásadók által kínált szolgáltatások e szempont szerint meglehetősen heterogének. Fellelhetők kifejezetten autentikus környezetben elérhető, a táj adottságaiból és hagyományaiból táplálkozó kínálati elemek, de előfordulnak kifejezetten e térséghez nem köthető szolgáltatások is, bár ma már ezek is a fogyasztói alapigényekhez sorolhatók (pl. falusi szálláshelyeken jacuzzi, szauna, úszómedence) (ld. Fotómelléklet). A vizsgált szálláshelyek negyede ért el maximális 10-es pontszámot e kritérium szerint, ugyanakkor a nagy többség átlagos értéket kapott, és a webes tartalomelemzés során - ugyanúgy mint a kérdőíves felmérés eredményei alapján bebizonyosodott, hogy szálláshely mellé általában kevés vagy kis hozzáadott értékü turisztikai szolgáltatást kínálnak a szállásadók. A jövőben jó lenne, ha ebben érezhető változás történne, hiszen a vendég a szabadidő tartalmas, élményt kínáló eltöltésére alkalmas programokat is elvárja. Szerencsés módon kevés (5\% alatti) a kirívóan gyenge, tájidegen szolgáltatásokat kínáló falusi szállásadó, azonban a honlappal nem rendelkezőket is beleszámítva arányuk minden bizonnyal magasabb.

Az általában városiasabb településeken jellemző „egyéb” szálláshelyeknél is - az előzetesen várthoz képest - magas „vidékiség faktor” adódott. Ennek oka lehet egyfelől, hogy ezen csoportnál is keverednek a városias és vidékies szolgáltatási elemek, másfelől mint korábban is jeleztem - a 2009-es jogszabályi és adatgyüjtési szabályok változása miatt ezen szállásadói csoport jelentős része korábban falusi szállásadó volt, de az adminisztratív szabályok változása miatt átkerült ebbe az „egyéb” kategóriába. Az alföldi kereskedelmi 
szálláshelyeknél is viszonylag magas érték adódott a vidékiséget tekintve, ami több tényező miatt alakulhat ki. A kereskedelmi szálláshelyek csoportja eleve heterogén, hiszen a szállodák mellett ide tartoznak a panziók, kempingek és üdülőházak is, melyek jellegüknél fogva - mint ez esetben is - kifejezetten vidékies kínálattal jellemezhetők. Másfelől, ha az adott szálláshely vidékies településen (térben) található, az kihat a szolgáltatásaira, megjelenésére is, és ezáltal rurális jellege erősödik.

Feltünő volt valamennyi szállástípusnál, de különösen a kereskedelmi szálláshelyeknél a fürdőkre épülő egészségturizmus nagyon markáns megjelenése a kínált szolgáltatások között. A fürdővel rendelkező településeken lévő szálláshelyek egyértelmüen erre építik szolgáltatási palettájukat, sőt a legismertebb fürdővárosokban szinte kizárólagosan ez a fő kínálati elem, más programlehetőségek csak kiegészítő jellegűek.

Az egyéb turisztikai szolgáltatók (fürdők, lovas tanyák, kikötők, csárdák, látogatóközpontok) vidékiségére kapott viszonylag magas pontszámok nem meglepőek annak tükrében, hogy ez a csoport kifejezetten a táj belső adottságaira épít, azokból alakítja ki és kínálja attrakcióit a vendégeknek.

A szolgáltatások (és a szolgáltatók) vidékiségének településtípusonkénti vizsgálata összevethető kérdőíves felmérés eredményeivel és a Bernard Lane által kidolgozott „Rurális turizmus” koncepcióval. A legkisebb (5000 fő alatti) településeken elérhető szolgáltatók több mint 50\%-a átlag feletti vidékies pontszámot kapott. Nem sokkal alacsonyabb (45\%-os) értéket értek el ugyanilyen vonatkozásban az 5-45 ezer fős kis- és középvárosok) turisztikai szereplői, sőt még az alföldi nagyvárosokban (45 ezer fö felett) müködő szolgáltatók vidékiségi faktora is 30\% feletti. Jelentős mértékü tehát a keveredés, amint az Lane koncepciója alapján feltételezhető volt, és primer kutatásom eredményeiből is leszürhető.

Építészeti sajátosságaikat tekintve a legalacsonyabb átlagos érték - meglepő módon a falusi szálláshelyeknél adódott. Ez leginkább abból adódott, hogy köztük igen magas azok aránya, amelyek modern kialakításúak. Ez annak is köszönhető, hogy az elmúlt 5-6 évben, jórészt Európai Uniós támogatásból jelentős számú falusi szálláshely épült vagy újult meg. Gyakran találhatunk köztük „klasszikus” családi házakat („kockaház”), modern vízparti nyaralókat, melyek csekély építészeti értéket képviselnek. (ld. Fotómelléklet). S kevés az igazán autentikus falusi vendégház. Leginkább Beregben, a Kiskunságban Bugac környékén és elszórtan néhány, egykori tanyából kialakított szálláshely tartozik e csoportba. 
Az egyéb és a kereskedelmi szálláshelyek magasabb értéke abból is adódhatott, hogy az adott településhez, térhez viszonyítottam építészeti sajátosságaikat (ugyanígy történt a falusi szálláshelyek esetén is). Ha tehát egy adott szálláshely a körülvevő térbe beleillett, magán viselte a település jellegéből (pl. kisváros) adódó jegyeket, viszonylag magas pontszámot kaphatott.

A honlapok vizsgálata a turisztikai szektoron belüli együttmüködések tekintetében is információkkal szolgál. A falusi és a kereskedelmi szálláshelyeknél jellemző leginkább a kooperáció, egymás szolgáltatásaink bevonása a saját kínálati palettába, csomagajánlatok kidolgozása, egymás kínálatainak kölcsönös ajánlása. Ahogy azt a kérdőíves felmérés eredményei is mutatták, az egyéb szálláshelyek legtöbbször csak elszállásolási lehetőséget kínálnak, a szabadidő eltöltésére alkalmas programokat nem vagy nagyon kevés esetben. Honlapjaik is hasonló képet mutatnak, programlehetőségeket nem vagy csak felsorolásszerüen jelenítenek meg. Az egyéb szolgáltatók esetén kapott igen alacsony érték elgondolkodtató, további részletesebb vizsgálatot igényel, hiszen együttmüködésük kulcsfontosságú lehet az egész ágazat jövője szempontjából.

A naprakészen tartott honlap alapvetö elvárás ma már a turisztikai szektorban is. Akkor várható vendég, ha friss információkat kaphat az interneten keresztül. A szolgáltató mérete, humán kapacitásai ez esetben is meghatározóak. A kereskedelmi szálláshelyek előnye e téren szignifikánsan kimutatható, messze az átlag feletti honlapjaik frissessége. Sajnos a falusi és egyéb szolgáltatók esetén valószínűsíthetően a humán és pénzügyi erőforrások szükössége miatt inkább átlagos szintet képviselnek, míg az egyéb szálláshelyek weboldalai ezen szinttől is elmaradnak. Pedig jóval ésszerübb lenne a saját honlapon történő kommunikációt erősíteni és naprakésszé tenni, mint egyes gyenge eredményeket produkáló szállásértékesítést végző honlapokon hirdetni. Ráadásul ma már valamennyi internetes megjelenés alapját jelenti egy korrekt tartalmú, saját weboldal.

A honlapokról alkotott összkép az ötletes kialakítást, a tetszetős kivitelezést, a szöveges és képi elemek harmóniáját foglalta össze. Itt került értékelésre az önálló domain név megléte vagy hiánya. A vizsgált weboldalak mindezeket együttesen vizsgálva nagyon széles skálán mozognak. A legegyszerübb, néhány menüpontból álló honlaptól az ötletes, tartalmas, harmonikus kialakítású dinamikus oldalig minden típus előfordul. A viszonylagosság elvét ez esetben is alkalmaztam, azaz a kisebb szálláshelyek és szolgáltatók esetén egy harmonikus kialakítású, kellő információmennyiséggel rendelkező weboldal szolgálhatja az interneten való hatékony megjelenést, míg pl. egy nagyobb szállodánál elvárható a dinamikus, közvetlen foglalási lehetőséget kínáló honlap. 
13. táblázat: A honlapok átlagos pontszámai főbb szolgáltatói típusonként (pont)

\begin{tabular}{|l|c|c|c|c|c|c|}
\hline & $\begin{array}{c}\text { Vidékiség, } \\
\text { „alföldiség” }\end{array}$ & $\begin{array}{c}\text { Építészeti } \\
\text { jegyek }\end{array}$ & $\begin{array}{c}\text { Együtt- } \\
\text { múködés }\end{array}$ & $\begin{array}{c}\text { Honlap } \\
\text { aktualitása }\end{array}$ & Összkép & Összesen \\
\hline $\begin{array}{l}\text { Falusi } \\
\text { szálláshelyek }\end{array}$ & 7,77 & 5,77 & 6,63 & 7,68 & 7,11 & 34,96 \\
\hline $\begin{array}{l}\text { Egyéb } \\
\text { szálláshelyek }\end{array}$ & 7,09 & 5,82 & 6,56 & 7,55 & 6,64 & 33,66 \\
\hline $\begin{array}{l}\text { Kereskedelmi } \\
\text { szálláshelyek }\end{array}$ & 6,82 & 5,84 & 6,16 & 8,04 & 6,96 & 33,76 \\
\hline $\begin{array}{l}\text { Egyéb } \\
\text { turisztikai } \\
\text { szolgáltatók }\end{array}$ & 7,21 & 5,94 & 4,85 & 7,01 & 6,98 & 31,99 \\
\hline
\end{tabular}

Forrás: saját adatgyüjtés és szerkesztés

14. táblázat: A szolgáltatói honlapok összpontszámainak megoszlása kategóriák szerint (\%)

\begin{tabular}{|c|c|c|c|c|c|c|}
\hline $\begin{array}{c}\text { Falusi } \\
\text { szálláshelyek }\end{array}$ & $\mathbf{1 - 1 0}$ pont & $\mathbf{1 1 - 2 5}$ pont & $\mathbf{2 6 - 3 5}$ pont & $\mathbf{3 6 - 4 5}$ pont & $\mathbf{4 6 - 5 0}$ pont & Összesen \\
\hline $\begin{array}{c}\text { Egyéb } \\
\text { szálláshelyek }\end{array}$ & $0 \%$ & $18,7 \%$ & $30,9 \%$ & $30,1 \%$ & $19,5 \%$ & $100 \%$ \\
\hline $\begin{array}{c}\text { Kereskedelmi } \\
\text { szálláshelyek }\end{array}$ & $1,4 \%$ & $11,6 \%$ & $42,0 \%$ & $34,8 \%$ & $10,1 \%$ & $100 \%$ \\
\hline $\begin{array}{c}\text { Egyéb } \\
\text { turisztikai } \\
\text { szolgáltatók }\end{array}$ & $0 \%$ & $12,5 \%$ & $46,4 \%$ & $32,1 \%$ & $8,9 \%$ & $100 \%$ \\
\hline \begin{tabular}{c} 
Összesen \\
\hline
\end{tabular} & $0,7 \%$ & $15,7 \%$ & $37,4 \%$ & $32,7 \%$ & $13,6 \%$ & $100 \%$ \\
\hline
\end{tabular}

Forrás: saját adatgyüjtés és szerkesztés

6.6.2. Turisztikai desztinációkat bemutató honlapok jellemzői

A turisztikai internetes tartalmak vizsgálata során nem csak az egyes szolgáltatók, hanem a különböző területi egységek, desztinációk világhálón történő megjelenései is érdemben hatással lehetnek a szektor müködésére, optimális esetben jelentősen segíthetik 
azt. A járási szintű vizsgálat - korábbi vizsgálataimhoz hasonlóan - ez esetben is kézenfekvő, hiszen azok sok esetben a turizmus egy-egy szükebb régióját, célterületét is jelentik.

A térségi szemléletű honlapok fenntartói, üzemeltetői változatos képet mutatnak. Nyolc esetben lelhető fel az Alföldön Turisztikai Desztináció Menedzsment Szervezet (TDM) által üzemeltetett önálló honlap; öt térségben a TDM vagy a központi város által üzemeltetett, általában a honlap aldomain-jeként müködő a weboldal; további öt területen a Tourinform Iroda, egy turisztikai egyesület, Mủvelödési Ház által üzemeltett, önálló honlap fordult elö. Ezek a tulajdoni és üzemeltetési formák kellően részletes, önálló arculattal rendelkező megjelenési lehetőséget biztosítanak a turisztikai ágazat számára. Ezektől jóval szerényebb bemutatásra ad módot a leggyakrabban alkalmazott módszer (36 térség esetén), amikor a centrumtelepülés honlapján almenüként jelent meg a turisztikai kínálat. Sajnos a vizsgált 70 járás ötödéről semmilyen turisztikai információ nem érhető el a világhálón vagy azért, mert az imént említett lehetőségek egyikét sem alkalmazták, vagy pedig egyszerüen üres volt a „Turizmus” almenü. Meg kell azonban jegyezni, hogy ezen térségek általában nagyon szerény vonzerőkkel rendelkeznek, és mint arra a statisztikai adatok elemzését bemutató fejezetben rámutattam a vendégforgalom is minimális.

Az értékelhetőség és az összehasonlíthatóság végett a térségi weboldalakat a korábban jelzett szempontok szerint pontoztam, majd kategóriákba soroltam. Az elérhető maximális pontszám $(5 * 10=50$ pont) felét el nem érő honlapok a gyengének minősíthetők, a 26-35 pontot elértek közepesek, a 36-45 pontot szerzettek a „Jó”, a 46 pont felett teljesítőket a „Nagyon jó” kategóriába kerültek.

15. táblázat: A desztinációk honlapjai* kategóriák szerint (db)

\begin{tabular}{|l|c|c|c|c|c|}
\hline & $\begin{array}{c}\text { Gyenge } \\
\text { honlap } \\
(1-25 \text { pont })\end{array}$ & $\begin{array}{c}\text { Közepes } \\
\text { honlap } \\
(26-35 \text { pont })\end{array}$ & $\begin{array}{c}\text { Jó honlap } \\
(36-45 \text { pont })\end{array}$ & $\begin{array}{c}\text { Nagyon jó } \\
\text { honlap } \\
(46-50 \text { pont })\end{array}$ & Összesen \\
\hline $\begin{array}{l}\text { TDM által üzemeltetett önálló } \\
\text { honlap }\end{array}$ & 0 & 0 & 0 & 8 & 8 \\
\hline $\begin{array}{l}\text { TDM vagy város által } \\
\text { üzemeltetett aldomain }\end{array}$ & 0 & 3 & 1 & 0 & 5 \\
\hline $\begin{array}{l}\text { Tourinform Iroda vagy egyéb } \\
\text { fenntartó által üzem. honlap }\end{array}$ & 2 & 2 & 1 & 1 & 37 \\
\hline $\begin{array}{l}\text { Központi város honlapján } \\
\text { almenü }\end{array} \quad 19$ & 13 & 4 & 10 & 55 \\
\hline Összesen & 21 & 18 & 6 & & 5 \\
\hline
\end{tabular}

Forrás: Internet, saját adatgyüjtés és szerkesztés; *Megjegyzés.: Nincs honlap 15 térségben. 
Az eredmények alapján kapcsolat mutatható ki a professzionális térségi/helyi turisztikai honlap és a regisztrált TDM szervezetek megléte között. Ahol TDM szervezet működik az Alföldön, ott többségében jó minőségü, információgazdag honlap szolgálja a szektor minél hatékonyabb müködését és a turizmust. Ez több tényező együttes hatásaként magyarázható. Egyrészt a TDM-ek a helyi és térségi együttmüködés magasabb szintjét jelentik, és általában ott müködnek, ahol a vendégforgalom elér egy olyan szintet, amely révén a turisztikai ágazat jelentős szerepet tölt be a térség/település gazdaságában. Ezek együttesen szinte megkövetelik a korszerü turistatájékoztatás elengedhetetlen eszközéül szolgáló honlap kifejlesztését és webes megjelenést. Másrészt pénzügyi forrásaik is jóval nagyobbak, amit EU-s forrásokkal is meg tudtak toldani a 2007-2013-as fejlesztési ciklusban. Ezekböl a szervezet- és infrastrukturális fejlesztések mellett informatikai fejlesztésekre is jelentős összegeket költhettek, aminek eredménye meg is mutatkozik internetes megjelenésiekben. Tartalmukat és a kínált szolgáltatások jellegét illetően vegyes: a vidékies, a köztes és városias szolgáltatások egyaránt előfordulnak. A regisztrált TDM szervezet megléte nem jelenti törvényszerüen, hogy kimagasló webes tartalom érhető el egy adott területröl, hiszen akad arra is példa (pl. Kalocsa), ahol müködik TDM szervezet, de önálló turisztikai információs portál nincs, csak a központi város honlapján juthatunk némi információhoz a város nevezetességeit és szálláshelyeit illetően. Olyan is előfordul, hogy ugyan nincs TDM szervezet, mégis felismerték a világhálón való jelenlét pótolhatatlan szerepét, és nagyon korrekt, térségi szemléletü honlapot müködtetnek (Fehérgyarmat és környéke).

Az egyéb szervezetek által müködtetett és önállóan vagy a központi város honlapján lévő turisztikai tartalmak kevéssé átfogók és kidolgozottak. A turisztikailag frekventált települések honlapjához kapcsolódó aldomain jó megoldás lehet, ha a tartalma eléri a kívánatos szintet, hiszen így két tartalom szorosan összekapcsolódik, a városról információt kereső felhasználó viszonylag egyszerüen juthat turisztikai információkhoz is. A megvizsgált alföldi példák (pl. Mórahalom, Kiskunhalas, Makó, Ráckeve térsége) többsége a pontszámok alapján közepes vagy jó minősítést kaptak.

Némileg kedvezőtlenebb a kép a civil szervezetek, Müvelődési Házak és egyéb fenntartók által müködtetett 5 honlap esetén, a potenciális felhasználók (turisták) elérése is nehézkes lehet. A településekről és térségekről elérhető internetes tartalmak nagy többsége a központi vagy turisztikailag frekventált város honlapjának almenüjeként lelhető fel. Ez a megjelenési mód jelentősen korlátozza a közzétehető információmennyiséget, ugyan akkor 
azok elérése a központi honlapon történő elhelyezéssel könnyebb a felhasználó számára. Zömmel alacsony vendégforgalmat produkáló területek (néhány példaként Jászberény, Mezőtúr, Berettyóújfalu, Csongrád), alkalmazzák ezt a módszert, de meglepő módon a Délalföldi régió egyik turisztikai centruma, Kecskemét is ezzel a megoldással él. (Korábban müködött önálló, turisztikai információkat közlő honlap a városról, de vizsgálataim idején nem volt elérhető.)

\section{1. ábra: Térségi (desztinációs) honlapok minőségi kategóriái}

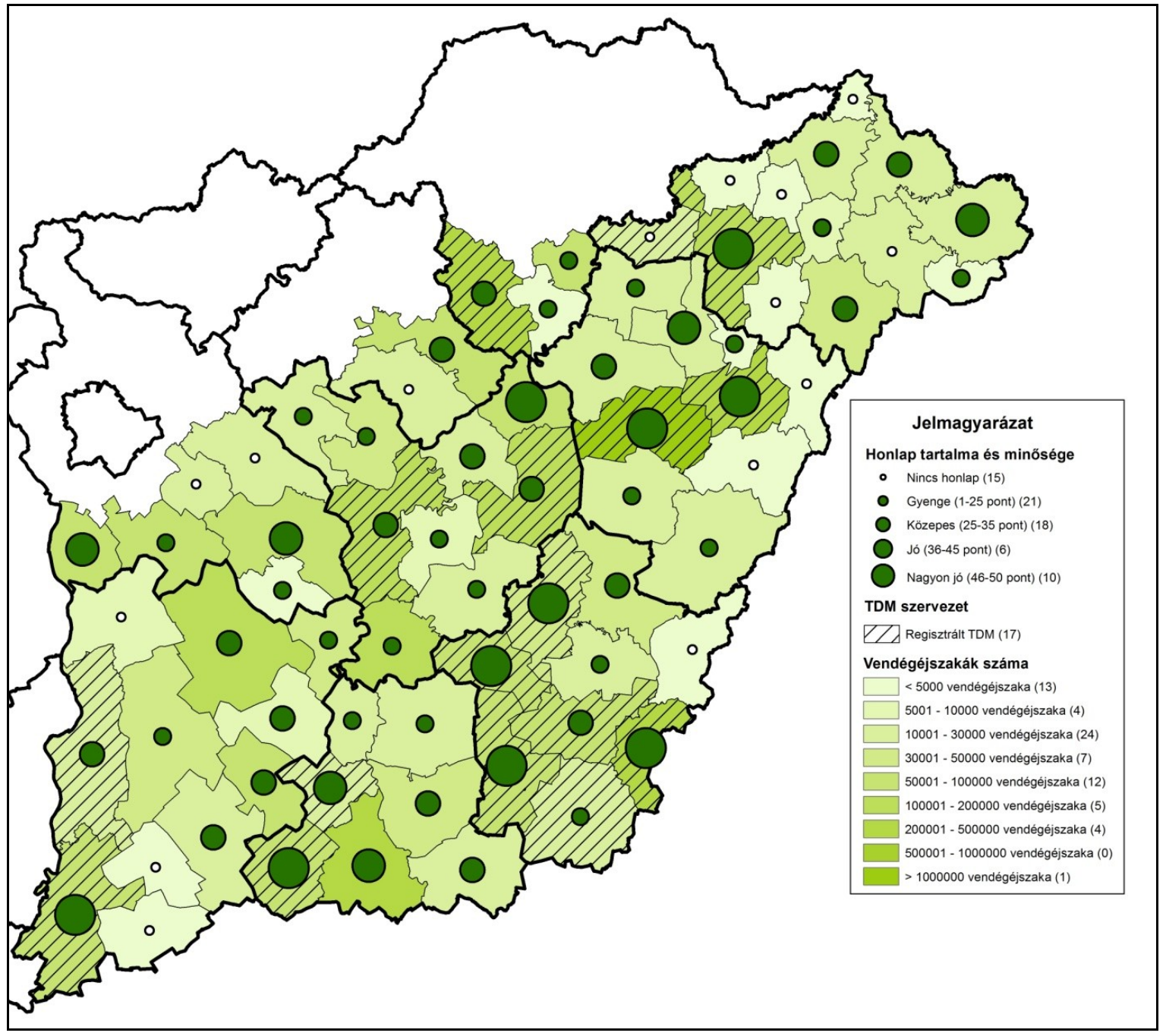

Forrás: saját adatgyüjtés és szerkesztés, TeIR

Úgy gondolom, hogy a szerényebb vonzerőkkel és adott pillanatban csekély vendégforgalommal rendelkező térségek számára is megkerülhetetlen és célszerü is turisztikai információk közlése az internet segítségével. Mint tartalomelemzéseim alátámasztották ezen térségekben is - ha kisebb számban is - de lehetnek olyan turisztikai szereplők, amelyek értékes szolgáltatásokat nyújtanak, s munkájukat a segíthetné az adott terület értékeit átfogóan bemutató internetes tartalom. Ahol pedig már valamilyen formában 
létezik ilyen weboldal, ott azok lehetőség szerint teljes körűvé tétele és folyamatos karbantartása, aktualizálása szükséges, ami szoros együttmüködést kíván a szektor helyi szereplőivel. Látható tehát, hogy az együttmüködés ezen módja (a helyi szereplők és a térségi szint között) is fontos láncszeme az ágazat hatékony müködésének. Ezt támasztják alá a korábbi fejezetekben bemutatott elméleti megközelítések (térségfejlesztési modellek, Intergált Rurális Turizmus modell), melyek mind-mind az érdekelt felek közötti magas fokú kooperáción alapulnak. S mint kérdőíves felmérésemből világossá vált és saját tapasztalataim is megerősítik, az alföldi turisztikai szektorban tapasztalható együttmüködések mennyiségi és főleg minőségi értelemben is fejlesztésre szorulnak.

Az alföldi turizmust működtető szolgáltatók és az azokat összefogó térségek honlapjainak vizsgálata nyomán a régió turizmusának vidékies vonásai megfigyelhetők valamennyi település és szolgáltatói típus esetén. Nyilvánvalóan ez legerőteljesebb a kisebb településeken működő szolgáltatók esetén. A szolgáltatások legnagyobb hányada azonban átlagos szintet ér el, minőségi fejlesztésük és még helyspecifikusabbá tételük nagyban javítaná „eladhatóságukat”. Az alföldi turizmus vidékies jegyei az internetes megjelenéseken is felfedezhetők, de ez esetben is kívánatos lenne a minőség javítása, sőt a turisztikai szereplők interneten történő jelenlétét is növelni kellene.

A világhálón lévő honlapok elemzéséből és a korábban ismertetett kérdőíves felmérés eredményeiből az is kitünik, hogy a szektor szereplői közötti és a magasabb területi (térségi) szinttel folytatott együttmüködések intenzitását növelni kellene. Mindezek együttesen járulhatnának hozzá a turizmus szektor érzékelhető fejlődéséhez és hatékonyabb müködéséhez. 


\section{7. Összefoglalás, konklúziók, javaslatok}

Értekezésem végén igyekszem összefoglalni mindazon konklúziókat, amelyek dolgozatom elkészítése során és annak tartalma alapján felszínre kerültek.

A vidéki térségek átalakulási folyamatainak eredményeként Nyugat-Európában jelentősen átstrukturálódott a vidékgazdaság, mára integráns részévé, sőt sok országban meghatározó ágazatává vált a turizmus. Hazánk vidéki térségei a fejlett Európától eltérő utat jártak be, így gazdaságukban még jóval szerényebb szerepet tölt be az ágazat.

Az alföld természeti földrajzi viszonyai, a természet alkotta erőforrások dominánsan meghatározzák egy-egy tájegység arculatát, bizonyos mértékig gazdaságát, de hatással vannak a sok évszázad alatt kialakult társadalmi viszonyaira, hagyományrendszerére, s ezek révén együttesen a mindezeket magába integráló turizmusra is. Leszögezhető, hogy a térség természeti-táji és ember alkotta erőforrásai nagyon sokszínűek és változatosak, tájegységenként eltérőek. Egyedi kombinációikra alapozva jönnek létre térségenként a turisztikai vonzerők és termékek. Bennük erősen keverednek a vidékies és a városias elemek, sőt jelen van egy erős köztes vagy más szóval átmeneti kategória. Bernard Lane turisztikai termékekre vonatkozó tipizálása (vidéki, „köztes”, városi) az Alföldön is érvényes, sőt ezt lenne célszerü széles körben alkalmazni, mint arra a vidékturizmus koncepció felvázolásával jómagam is javaslatot tettem.

Kiemelkedőek az Alföld egyedi földrajzi adottságaiból és vidékiségéből eredő vonzerök.

Hazánk és különösen az Alföld kedvező geotermikus adottságai révén termál- és gyógyvizekben a világ leggazdagabb területei közé tartozik, az ezen vonzerőkre alapozott egészségturizmus generálja a régió vendégforgalmának döntő többségét. Emellett igen markánsak a térség hagyományokra épülő ember alkotta vonzeröi, különösen a mezőgazdasághoz és élelmiszer előállításhoz kapcsolódó tradíciók, melyek ma leginkább az egykori hagyományos életmódhoz köthető kulturális örökségben, a gasztronómiában és a népi építészet ránk maradt elemeiben jelennek meg és válnak turisztikai vonzerővé.

A számszerüsített adatokat tekintve az Alföld turizmusa jelenleg térben erősen koncentrált, fürdővárosok és az alföldi nagyvárosok járásaiban (hajdúszoboszlói, debreceni, gyulai, mezőkövesdi, szegedi) koncentrálódik a regisztrált vendégéjszakák több mint fele. 
Jellemzően a fürdőhelyeken, nagyvárosokban és megyeszékhelyeken produkál a turizmus olyan volumenű forgalmat és bevételi forrást, amely számottevő és érzékelhető fejlesztő hatást tud kifejteni. A vidékies kínálattal turisztikai térségek a statisztikai adatközlés szerint jóval kisebb vendégforgalmat realizálnak, mint az intenzívebb, városiasabb szolgáltatásokkal rendelkező területek.

A magyar jogszabályok és statisztikai adatgyüjtés szerint definiált „falusi turizmus” kategória csak egy kis szeletét képes lefedni a vidékies környezetben igénybe vehető turisztikai szolgáltatások nyomán keletkező vendégforgalomnak. A vidéki területek turizmusát bővítve, a jelenleginél - bizonyos tőlünk nyugatabbra fekvő országokhoz hasonlóan - jóval szélesebben lenne célszerü értelmezni, akár az általam felvázolt „,vidékturizmus” koncepció alapján.

$\mathrm{Az}$ értekezésben bemutatott, az alföldi turisztikai szakma véleményének megkérdezésével végzett primer kutatás alapján a turizmus társadalmi erőforrásai, köztük a szektoron belüli és az ahhoz kapcsolódó szereplőkkel való együttmüködések - bár térségenként eltérő minőségben - szerencsés módon jelen vannak az ágazatban és biztos alapot képeznek annak müködéséhez, de multiplikáló hatással bírna az eredményességre és a hatékonyságra az érdekelt felek mostaninál magasabb szintü, hatékonyabb kooperációja. Az viszont mindenképpen biztató, hogy az utóbbi években az ország más, Budapesten kívüli területeihez képest az Alföld turizmusának számszerüsíthető bővülése dinamikusabb. $\mathrm{Az}$ is reményt keltő, hogy a kutatásaim során választ beküldő szállásadók és turisztikai szolgáltatók több mint 4/5-e bizakodó tevékenysége jövőjét illetően. Az elmúlt évtized turisztikai ágazatba történt befektetéseinek látványos, kézzel fogható eredményei vannak, de a fejlesztések akkor teljesedhetnek ki és válthatják be a hozzájuk füzött reményeket, ha a térség humán és társadalmi erőforrásai is fejlődnek.

\section{Javaslatok}

$\mathrm{Az}$ értekezés elkészítése során tudatosan törekedtem arra, hogy jövőbe mutató gondolatokat is megfogalmazzak, vagy ezek irányába kutatásokat végezzek. Most zárásként, összefoglaló jelleggel ezeket veszem számba.

Mikroszinten, azaz a turisztikai szolgáltató (programgazda, szállásadó) szintjén úgy gondolom, hogy az Alföld turisztikai kínálatának jelentős minőségi fejlesztése szükséges még inkább a speciális, csak e térségre jellemző turisztikai kínálat felé történő 
elmozdulással. Másként megfogalmazva - úgy vélem - a jelenleginél jóval nagyobb, a helyi hagyományokból, csak itt meglévő tudásból és kreativitásból származó „helyi hozzáadott érték" szükséges a turisztikai kínálat minőségi fejlesztése érdekében. Ennek eléréséhez azonban a humán erőforrások, az emberi tudás gyors és hathatós fejlesztése elengedhetetlen. Kiművelt, széles látókörü, nyitott, innovatív szakemberekre lenne szükség a turisztikai szolgáltatók szintjén is.

Makroszinten úgy kell alakítani az ösztönzőket, közte a turizmus fejlesztését szolgáló források allokációját, hogy az a szolgáltatások minőségének javulását eredményezze.

Kijelenthető, hogy az Alföld régió gazdag endogén erőforrásaira alapozható a turizmus fejlesztése, amit a kérdőívekre adott válaszok is alátámasztottak. Erre alkalmas módszer lehet erre az Európa szerte elterjedt LEADER ${ }^{14}$ modell, melynek alapvető jellemzője a belső erőforrásokra bevonása mellett a köz- és magánszféra szoros együttmüködése annak érdekében, hogy közös kezdeményezéseket tudjanak megvalósítani.

Új színt vinne az Alföld, de akár egész Magyarország turizmusának müködésébe, az általam részletesebben is bemutatott, Saxena és Ilbery által kidolgozott, s Nyugat-Európa számos országban alkalmazott Integrált Rurális Turizmus (Integrated Rural Tourism = IRT) modell. Ennek legföbb sarokpontja, hogy a vidéki terülteken a helyi szereplök társadalmi hálózatokká kapcsolódnak össze. Ennek erőforrásai jórészt jelenleg is megvannak, ezt a kutatásaim részét képező kérdőíves felmérés egyes eredményei is alátámasztották. A szektoron belüli és kívüli kooperációk léteznek, de belső tartalmuk gazdagabbá tétele, szorosságuk és a hatékonyáguk további növelése szükséges.

Úgy vélem vizsgálataim során egy nagyon izgalmas és összetett kép tárult fel az Alföld turizmusa kapcsán. Jóllehet számos problémával és nehézséggel küzd az ágazat e térségben, de a fejlődés lehetőségei mindenképpen felismerhetők, s kitartó szorgalmas munkával az eredmények sem maradhatnak el.

\footnotetext{
${ }^{14} \mathrm{~A}$ „Liaisons entre actions pour le développement de l'économie rurale” francia betűszó magyar fordítása: „Közösségi kezdeményezés a vidéki gazdaság fejlesztéséért”.
} 


\section{Summary}

Tourism has now become a highly dynamic leading business in the world. While it is primarily an urban phenomenon by nature, it has gained ground in the changing rural areas over the past few decades. In a number of developed countries, tourism based on the sustainable exploitation of local inner resources has become a powerful sector of "rural economy" and a key factor of rural development. While tourism in the Great Hungarian Plain has made considerable progress concerning both quantity and quality in the last period of more than two decades, it is struggling with a number of problems that could only be solved by planning and development built on thorough research. It seems reasonable, then, to analyse tourism in the Great Hungarian Plain from the perspective of regional and tourism geography in a new, systematic and comprehensive way, to explore the various relationships between attractions and guest turnover, and to survey the opportunities of tourism regarding the various aspects of geography and rural economy.

This thesis presents its subject with a review of the relevant European literature, proceeding from the general problems to the individual. To this end, it first quotes the international and Hungarian definitions of "rural area" and the latest findings of rural research in Hungary. The thesis then explores the main characteristics of the multiple connections between rural geography and tourism geography, and the various European and Hungarian approaches to tourism in rural areas. These theoretical considerations are followed by my own conception of rural tourism. Using the relevant literature, I interpret the terms inner resources and tourism resources of rural areas and their role in rural economy. Then the thesis presents tourism supply in the Great Hungarian Plain and its special geographic elements that are characteristic of the region. My secondary research used the existing tourism databases to analyse the main data and the temporal and spatial processes of tourism in the region. My primary research included a targeted online questionnaire to survey the opinions and approaches of tourism professionals in the Great Hungarian Plain, as well as the main geographic characteristics of their appearance on the Internet.

The specific analyses in this thesis cover all six counties of the Great Hungarian Plain (Bács-Kiskun, Békés, Csongrád, Jász-Nagykun-Szolnok, Hajdú-Bihar and SzabolcsSzatmár-Bereg) with another 11 administrative subunits in the Great Hungarian Plain (the Districts of Cegléd, Dabas, Monor, Nagykáta, Nagykőrös, and Ráckeve in the County of 
Pest; the Districts of Füzesabony and Heves in the County of Heves; and the Districts of Mezőcsát, Mezőkövesd and Tiszaújváros in the County of Borsod-Abaúj-Zemplén), a total of 70 districts. In other words, this thesis is about the natural geographic plain that can be described by administrative limits and is the basis of rural tourism supply in the region.

This research project sought answers to the following questions:

- How did the role of tourism change in the economies of Europe's developed rural areas after World War II?

- Is it possible to adapt the rural tourism approaches and models of such areas to the Great Hungarian Plain? Is it possible to create a rural tourism model for the Great Hungarian Plain?

- What are the key individual and rural elements of tourism supply in the Great Hungarian Plain? How has tourism changed in the Great Hungarian Plain over the past 15 years? What are the key nuclear areas of tourism?

- What are the most important local and inner resources of the Great Hungarian Plain? Does the region have the social and human resources that are vital for the future development of its tourism?

Based on Hungarian regional typology relying on international research findings, the Great Hungarian Plain is a typical Hungarian rural region. Except for the districts that include county towns and others with special conditions, its territory is almost completely rural and hence suitable for various types of social geographic research using the criteria of rural tourism.

There are various approaches to the scope and name of tourism in rural areas. In Hungary the most common term is "village tourism" but it is increasingly replaced by "rural tourism" as a broader term. In Western Europe, the concept is usually called "rural tourism" and is interpreted quite broadly, as was done by Bernard Lane in his research into the subject. In his theory, adopted by this thesis, tourism in rural areas does not consist of purely rural elements. Instead, it is a mixture of rural and urban elements. Indeed, there is an "intermediate" category between the two main types. Lane's model was readily adaptable to tourism in the Great Hungarian Plain as the region exhibits the mixture that he proposed. The urban, intermediate and rural types of tourism are present together in each region, if with different intensity and shares, and they jointly constitute tourism supply in the given region. "Rural tourism", presented in the thesis with respect to tourism in the 
Great Hungarian Plain, is a much broader and wider term than tourism in the villages or the country. The Central Statistical Office does not gather data directly about the performance of rural tourism so it can only be inferred from other statistical data. Taken in its sense used in this thesis, rural tourism accounts for $70 \%$ of the guest nights spent in the Great Hungarian Plain owing to a high proportion of rural areas.

The products of tourism in the Great Hungarian Plain are based on the region's attractions that are largely rural owing to the landscape, natural, locality and cultural conditions. Thermal waters are outstanding attractions and have created self-contained destinations. The localities with a spa in the Great Hungarian Plain have an outstanding capacity to attract and receive visitors and they manage a high tourist turnover. The Great Hungarian Plain boasts of considerable natural assets. Specifically, the first two national parks of Hungary were founded in this region (the Hortobágy National Park in 1973 and the Kiskunság National Park in 1975). The region offers remarkable man-made attractions built on cultural values and traditions, especially traditions related to agriculture, food production, and gastronomy (including monuments, regional peasant houses, local foods, Hungaricums, equestrian traditions, etc.).

Tourism statistics reflect that the accommodations in the Great Hungarian Plain show a highly uneven geographic distribution and striking differences in capacity. Some of the districts offer fewer than 50 beds whereas there is one (Hajdúszoboszló) with a number above 17,000. This research has demonstrated the high territorial concentration of tourism in the region. Almost $50 \%$ of guest nights are spent in five districts (Hajdúszoboszló, Debrecen, Gyula, Mezökövesd, and Szeged). This reveals the dominance of tourism built on medicinal waters except for two regional centres (although they also manage such tourism). Concentration is also typical of localities. Those with the top 20 guest nights represent $3 / 4$ of the overall guest turnover and the top 10 represent nearly $60 \%$ of guest nights.

The currently valid and operative statistical data only include figures of "village tourism" about tourism in rural areas. However, this fairly narrow definition of the concept raises a number of problems. As the statutory and statistical concept of rural tourism underwent an apparently undue change in 2009, half of the landlords were excluded from this category also in the Great Hungarian Plain and they are now carrying on their business not as rural but as "other" landlords. This problem is a major obstacle to a realistic professional and scholarly analysis of the subject. In 2014 the number of registered guest nights in rural tourism, using its definition in force from 2010, was negligible, slightly more 
than $1.6 \%$ of all guest nights spent in the Great Hungarian Plain. The areas that are attractive in terms of rural tourism are most concentrated in Szatmár and Bereg, where this activity has evolved in the most complete and authentic way. Further regional foci are scattered across Hortobágy (the village of Hortobágy), near Lake Tisza (Tiszabábolna, Tiszadorogma, Tiszavalk), Hajdúság (Ebes, Derecske, Hajdúszovát), in the region of NagySárrét (Báránd, Sárrétudvardi), along the Danube (Harta, Dunafalva), and in the DunaTisza Interfluve (Akasztó, Bugac, Csólyospálos, Felsőlajos, Jászszentlászló, Ópusztaszer, Pusztaszer, Üllés).

My primary research consisted of a questionnaire about two factors that are relevant for tourism: the opinions of stakeholders about inner resources and collaborations related to the sector. Performed by asking tourism professionals in the Great Hungarian Plain, the primary research confirmed my hypothesis that the most important inner resources are natural factors. Of the man-made resources, the respondents primarily identified those related to agriculture (e.g. the traditions of local food production) and cultural heritage. Of the inner resources, tourism professionals in the Great Hungarian Plain considered the condition of human factors as one of the most unfavourable. More than one-third found them weak or poor and only one-fifth rated them as rather significant or highly significant.

While collaboration with the professionals of tourism and others related to the sector provide a solid basis for operating the sector, efficiency could be multiplied by a higher level of and more intense cooperation between stakeholders (landlords, event managers, local producers, tourism organisations, and local governments) as opposed to what most respondents found mediocre.

I used the method of content analysis to explore the qualitative and quantitative characteristics of the Internet appearances of tourism professionals as they determine the sector's operation. The Internet appearance of tourism professionals in the Great Hungarian Plain is below the national average in every service provider and landlord category. As is reflected by the websites of service providers operating tourism in the Great Hungarian Plain and of the regions that partly cover them, tourism has conspicuous rural features in the case of nearly each type of locality and service provider. Collaboration between tourism professionals in the Great Hungarian Plain and the territorial (regional) level offering a broader supply is below expectations in terms of intensity and should be enhanced.

One of the goals of this thesis was to make proposals for the manner and ways of the future development of tourism in the Great Hungarian Plain. An efficient way of development could be the LEADER model built on the involvement of inner resources and 
on close cooperation between the public and private sectors, and even the new CLLD cooperation, which encourages cooperation between cities and their rural areas. Further new possibilities could be offered for tourism in the Great Hungarian Plain and even in the whole of Hungary by Saxena-Ilbery's Integrated Rural Tourism (IRT) Model. While it is not a new idea, it is never enough to stress that quality improvement is vital for tourism services, and this requires qualified, creative and innovative human resources. This quality is now insufficient and its improvement calls for urgent action.

I think my research about tourism in the Great Hungarian Plain from multiple perspectives has offered a highly exciting and complex picture of this developing industry. Although it is still facing a number of problems and difficulties, the opportunities of its development are definitely identifiable and it only takes hard work to achieve the desired results. 


\section{Felhasznált irodalom}

AUBERT A. (2006): A turizmusföldrajz rendszertani helye és fóbb kérdései a földrajztudományban. Földrajzi Értesítő 2006/3-4. pp. 333-354.

BENDIXEN, P. (2004): A kultúra mint a regionális gazdaság fejlődésének motorja. Tudásmenedzsment, 5. évf., 1. sz. pp. 17-26.

BOKOR K. (2003): A tér mint erőforrás. In: Bora Gy. - Korompai A. (szerk): A természeti erőforrások gazdaságtana és földrajza. Aula Kiadó, Budapest. pp. 384-388.

BOZSIK N. (2010): A vidékgazdaság fogalomrendszere, erőforrásai. In: MAGDA R. MARSELEK S. (szerk.): Vidékgazdaságtan I. A vidékfejlesztés gazdasági folyamatai. Szaktudás Kiadó Ház. Budapest, 2010.

BRYDEN, J. M. (1998): Development strategies for remote rural regions: what do we know so far? Paper presented at the OECD Conference. Albarracen, Spain, 1998.

BURKART, A. and MEDLIK, S. (1981): Tourism, Past Present and Future, 2nd Edition, London: Heinemann. p. 366.

CLOKE, P.-PARK, C. (1985): Rural Resource Management. Croom Helm, London. p. 473.

CSATÁRI B. (2001): Európai vidékiség és az Alföld. Alföldi tanulmányok 2000/2001. XVIII. kötet: EU és az Alföld. Nagyalföld Alapítvány Békéscsaba, 2001. pp. 44-63.

CSATÁRI B. (2004): A magyarországi vidékiségről, annak kritériumairól és krízisjelenségeiről. Területi statisztika 44. évf. 2004/6. pp. 532-543.

CSIZMADIA L. (1993): Falusi turizmus - környezetbarát turizmus oktatási összefüggései. Kézirat. Hőgyészi Falusi turizmus konferencia, 1993.

CSIZMADIA L. (2013): Vidékfejlesztés, Falusi és Agrárturizmus. „A köles reneszánsza” konferencián elhangzott előadás írasosszefoglalója. http://koles.atw.hu/koles/eload/csizmadia/Dr_Csizmadia Laszlo Videkfejlesztes falusi es agrarturizmus.doc. Letöltve: 2015. október 10. 
CSORDÁS L. (1992): Az Alföld Turizmusa. Alföld I. kutatási program VIII. kötet. MTA Regionális Kutatások Központja. Kecskemét, 1992. p. 239.

CSORDÁS L. (1999): Változások az Alföld turizmusában. Alföld II. kutatási program. MTA Regionális Kutatások Központja. Kecskemét, 1999. p. 43.

CSORDÁS L. (2010): A magánüdülők építése és állománya Magyarországon. In: MEZEI I.

- BARABAS, D. (szerk.): Földrajzi dolgozatok határok nélkül - napjaink magyar természet- társadalom-és gazdaságföldrajzi írásaiból. MTA RKK Pécs. http://www.rkk.hu/rkk/news/2010/HU-SK_2_foldrajzi_dolgozatok_tarsadalomfoldrajz.pdf Letöltve: 2015. október 5.

DÁVID L. - JANCSIK A. - RÁTZ T. (2007): Turisztikai erőforrások. A természeti és kulturális erőforrások turisztikai hasznosítása Budapesti Gazdasági Főiskola. p. 289.

DÁVID L. (2007): A turizmus földrajzi alapjai. In: DÁVID L. - JANCSIK A. - RÁTZ T. (2007): Turisztikai erőforrások. A természeti és kulturális erőforrások turisztikai hasznosítása Budapesti Gazdasági Főiskola. pp. 7-61.

DORGAI L. (1998): Néhány gondolat a „Mi tekinthető vidéknek?” címü vitacikkhez. Gazdálkodás, XLII. évfolyam 5. sz. pp. 60-64.

ENYEDI GY. (2000): Globalizáció és a magyar területi fejlődés. Tér és Társadalom 14. évf. 1. sz. pp. 1-10.

FARKAS J. ZS. (2010): Agrár- és vidékföldrajzi kutatások Bács-Kiskun megyei példákkal. Doktori (PhD) értekezés. Szegedi Tudományegyetem, Természettudomány és Informatikai Kar. p. 180.

FEHÉR A (1998): A vidék fogalmáról és a vidéki területek lehatárolásáról. Gazdálkodás 1998/5. pp. 54-59.

FEHÉR A. (2005): A vidékgazdaság és a mezőgazdaság. Agroinform Kiadó, Budapest. p. 336.

FEHÉR I. - KÓRÓDI M. (2009): A vidéki turizmus fejlesztése. Szaktudás Kiadóház, Budapest. p. 196. 
G. FEKETE É. (2013): Integrált vidékfejlesztés. "Cross border training of economic experts in distance learning network" project (CROSSEDU) HUSK/1101/1.6.1-0300. Miskolc. p. 178.

GARROD, B. - WORNELL, R. - YOUELL, R. (2006): Re-conceptualising rural resources as countryside capital: The case of rural tourism. Journal of Rural Studies, Vol. 22., Issue 1. pp. 117-128.

GLATZ F. (2005): A vidék közhaszna. A „Párbeszéd a vidékért „ lakossági fórumainak tapasztalatai, megállapításai. http://www.glatzferenc.hu/upload/file/Ezredfordulo/E-200503a.pdf

GLÜNCKSMANN, R. (1935): Fremdenverkehrskunde. Bern.

HALL, C. M. - PAGE, S. J. (2006): The geography of tourism and recreation. Environment, place and space. (Third edition) London and New York. p. 530.

HANUSZ Á.-PRISTYÁK E. (2007): A turizmus szerepe egy vidéki térség szerkezet és funkcióváltásában. In: Földrajzi Közlemények, CXXXI/LV. kötet, 3. szám. Budapest, 2007. pp. 203-215.

HANUSZ Á. (2009): A területi turisztikai tervezés és a helyi TDM rendszerek kialakításának mozgástere a fehérgyarmati térségében. Turisztikai desztináció „desztinációs menedzsment”. Nyíregyháza, 2009. pp. 45-60.

HUNZIKER, W.- KRAPF, K. (1942): Grundriß der allgemeinen Fremdenverkehrslehre. Zürich: Polygraphischer Verlag.

JANCSIK A. (1998): Az Európai Unió turizmussal kapcsolatos intézkedései. KIT Képzőmüvészeti Kiadó. Budapest.

JANSEN-VERBEKE, M. (1990): The Potentials of Rural Tourism and Agritourism in EEC, University of Nijmegen, Netherlands.

JENKEI L. (2002): Idegenforgalmi értelmező kéziszótár. BGF Kereskedelmi, Vendéglátóipari és Idegenforgalmi Főiskolai Kar. p. 310. 
JÓNÁS-BERKI M. (2010): Tematikus parkok a turizmus rendszerében. PhD értekezés. Pécsi Tudományegyetem Természettudományi Kar Földtudományok Doktori Iskola. p 171.

KENÉZ GY.-né (1996): Falusi turizmus fejlesztése a harmincas években. A Falu, XI/4. sz. pp. 69-73.

KOVÁCH I. (2010): A jelenkori magyar vidéki társadalom szerkezeti és hatalmi változásai. MTA doktori értekezés. Budapest. p. 299.

KOVÁCH I. (2013): Vidék az ezredfordulón: A jelenkori magyar társadalom szervezeti és hatalmi változásai. Argumentum kiadó - MTA Társadalomtudományi Kutatóközpont (Szociológiai Intézet), Budapest.

KOVÁCS A. D. - FARKAS J. ZS. - PERGER É. (2015): A vidék fogalma, lehatárolása és új tipológiai kísérlete.. Tér és Társadalom 2015/1. pp. 11-34.

KOVÁCS D. (2000): „Falusi és vidéki turizmus” értelmezések a nemzetközi irodalomban. A Falu. XV. évf. 2000/1. szám. pp. 49-59.

KOVÁCS D. (2002): Falusi turizmus az átalakuló mezőgazdaság és a vidék gazdaságának egyik diverzifikációs lehetősége Magyarországon. PhD értekezés. Szent István Egyetem Gödöllő. p. 170.

KOVÁCS D. (2003): Falusi és vidéki turizmus értelmezések a nemzetközi irodalomban. In: Kovács Dezső (szerk.) A falusi turizmus hagyományai. Mezőgazda Kiadó, Budapest. pp. 55-67.

KOVÁCS D. (2015): Falusi turizmus Magyarországon - kérdések és dilemmák. Területi statisztika 2015/6. pp. 592-613.

KOVÁCS T. (1998): Mi tekinthető vidéknek? Gazdálkodás 1998/5. pp. 39-48.

KOZIEL M. (2010): A magánszállásadás helyzetének áttekintése, 1997-2009. Turizmus Bulletin XIV: évf. 2010/3. szám. pp. 50-57.

LANE, B. (1994): What is rural tourism? Journal of Sustainable Tourism. 1994/1-2. Special Issue: Rural Tourism and Sustainable Rural Development. pp. 7-21. 
LENGYEL I. (2012): Regionális növekedés, fejlődés, területi tőke és versenyképesség. In: Bajmócy Z.-Lengyel I.-Málovics Gy. (szerk.): Regionális innovációs képesség, versenyképesség és fenntarthatóság. JATE Press Szeged pp. 151-174.

LENGYEL M. (1992): A turizmus általános elmélete. KIT Képzőművészeti Kiadó és Nyomda. Budapest. p. 297.

LOWE, P. -MURDOCH, J. - WARD, N. (1995): Networks in rural development beyond exogenous and endogenous models. In: Ploeg, J.D. van der DIJK (eds.) Beyond modernisation, The impact of endogenous rural development. Van Gorcum, Assen. pp. 87105.

LORBERER Á. (2010): A hazai hévizek történetéhez, 1866-2010. História 2010/6-7. sz. pp- 55-58.

MARINI, M. B. - MOONEY, P. H. (2006): Chapter 6: Rural Economies. pp. 91-103. In. CLOKE, P.-MARSDEN, T.-MOONEY, P. (eds.): The Handbook of Rural Studies. SAGE Publications Ltd., London. p. 511.

MARSDEN, T (1998): New rural territories: regulating the differentiated rural space. Journal of rural Studies 14. pp. 107-117.

MICHALKÓ G. (2004): A turizmuselmélet alapjai. Kodolányi János Főiskola. Székesfehérvár p. 218.

MICHALKÓ G. (2007): Magyarország modern turizmusföldrajza. Dialóg-Campus kiadó. Budapest-Pécs 2007. p. 288.

MICHALKÓ G. (2008).: A turisztikai tér társadalomföldrajzi értelmezésének új dimenziói. MTA Doktori értekezés. Budapest. p. 211.

MIKLAY F.-NÉ (szerk.) (2007): Falusi turizmus tájékoztató. 2007/1-2. p. 28.

MITCHELL, C. J. A. (1998): Enterpreneuralism, commodification and creative desturction: a modell of post-modern community development. Journal of Regional Studies 14/3. pp. 273-286.

MURRAY, M. - DUNN, L. (1995): Capacity building forr ural development int he United States. Journal of Regional Studies 11/1. pp. 89-97. 
NÓGRÁDI Z. (2010): A vidék erőforrásai. Magyar szemle, 19. évf., 1-2. sz. pp. 35-44.

OLÁH J (2003): Vidékgazdaság diverzifikálás ás multiplikálás Magyar Tudomány, 49. (109.) évf. 7. sz. pp. 867-877.

OLÁH J. (2005): Mit ér a vidék? Valóság, XLVIII. évf. 12. sz. pp. 35-53.

PÓLA P. (2014): Helyi erőforrások, vidékfejlesztési stratégiák. In: Lukovics Miklós - Zuti Bence (szerk.): A területi fejlődés dilemmái. SZTE Gazdaságtudományi Kar pp. 267-276.

QUENDLER, T. (1986): Entwicklungsprogramm für die Lang- und Forstwirtschaft. LRAktuell, Steiermark. pp. 3-14.

RAY, C. (1998): Culture, intellectual property and territorial rural development. Sociologia Ruralis, Vol. 38, 1. pp. 3-20.

RÁTZ T. (2011): Attrakció- és látogatómenedzsment. In: AUBERT A. (szerk.) (2011): Turizmusmenedzsment. Pécsi Tudományegyetem Kempelen Farkas Hallgatói Információs Központ.

www.tankonyvtar.hu/hu/tartalom/tamop425/0051_Turizmusmenedzsment/ch06.htm

Letöltve: 2015. október 25.

ROBERTS, S. (2002): Key Drivers of Economic Development and Inclusion in Rural Areas. Initial scoping study of the socio-economic evidence base for DEFRA. p. 70. http://archive.defra.gov.uk/evidence/economics/foodfarm/reports/documents/sion.pdf (letöltve: 2015.02. 14.)

SARUDI CS. (2003): Térség- és vidékfejlesztés. A magyar térgazdaság és az európai integráció. Agroinform kiadó, Kaposvár.

SAXENA, G. - ILBERY, B. (2008): Integrated rural tourism. Annals of tourism research. 2008/1., pp. 233-254.

SPITZER, H. (1991): Raumnutzungslehre. Verlag Eugen Ulmer, Stuttgart.

SZABÓ G. (2006): Turizmus és földrajz: kapcsolatok az elméletben és a gyakorlatban, a kutatásokban és a tervezésben. In: Csorba P. szerk.: Egy szakmai életút eredményei és 
helyszínei - Tiszteletkötet Martonné Dr. Erdős Katalin 60. születésnapjára, Tájvédelmi és Környezetföldrajzi Tanszék, Debreceni Egyetem, pp. 227-253.

SZABÓ G. (2012): A hazai falusi turizmus helyzete és jövőképe In: Hanusz Á. (szerk.): A turizmus területi dimenziói. Nyíregyházi Főiskola Turizmus és Földrajztudományi Intézet. 2012. pp. 177-190.

TERLUIN, I. J. (2003): Differences in economic development in rural regions of advanced countries: an overview and critical analysis of theories. Journal of Rural Studies. Vol. 19. Issue 3. pp. 327-344.

TÓTH M. (1988): A természeti erőforrások potenciálja és igénybevétele gazdasági értékelésének elvi-módszertani kérdései. MTA FKI, Budapest. p. 183.

WARD, N (2008): Witness: Professor Neil Ward, Centre for Rural Economy, Newcastle Univer-sity, gave evidence. In: The potential of England's rural economy. Eleventh Report of Session 2007-08 Volume II. Oral and written evidence. House of Commons Environment, Food and Rural Affairs Committee. The Stationery Office Limited, London. pp. 7-16.

http://www.publications.parliament.uk/pa/cm200708/cmselect/cmenvfru/544/544ii.pdf (letöltve: 2015. 08. 12.)

VIDÉKKUTATÁS 2012-2013. Magyar Tudományos Akadémia Közgazdaság- és Regionális Tudományi Kutatóközpont Regionális Kutatások Intézete. MTA KRTK RKI ATO Kecskemét, 2013. 


\section{Felhasznált egyéb források}

110/1997. (VI. 25.) Kormány rendelet (1997): A magánszálláshelyek idegenforgalmi célú hasznosításáról. net.jogtar.hu Letöltve: 2015. október 19.

48/1998. (VI. 24.) IKIM rendelet (1998): A kereskedelmi és a fizetővendéglátó szálláshelyek osztályba sorolásáról, valamint a falusi szálláshelyek minősítéséről. www.fatosz.eu/ftp/jogszabalyok/45-1998.pdf. Letöltve: 2015. október 20.

239/2009. (X.20.) Kormány rendelet (2009): A szálláshely-szolgáltatási tevékenység folytatásának részletes feltételeiről és a szálláshely-üzemeltetési engedély kiadásának rendjéről. net.jogtar.hu Letöltve: 2015. október 19.

COUNCIL OF EUROPE (1996): Recommendation 1296 (1996) on a European Charter for Rural Areas http://assembly.coe.int/nw/xml/XRef/Xref-XML2HTMLEN.asp?fileid=15330\&lang=en Letöltve: 2016. január 12.

EUROPEAN COMMISSION (1988): The future of rural society. Bulletin of the European Communities 4/88. p. 68. $\quad$ http://ec.europa.eu/agriculture/cap-history/crisis-years1980s/com88-501_en.pdf Letöltve: 2015. október 12.

Herman Ottó Intézet (2015): Magyarországi Natúrparkok Fejlesztési Koncepciója 20152030.

http://www.naturparkok.hu/webimages/files/Naturpark_fejlesztesi_koncepcio_151218 tars adalmi_egyeztetes(1).pdf Letöltve: 2016. január 15.

NÉPSZÁMLÁLÁS 2011 (2016).: 20. A külterületen élők társadalmi, gazdasági jellemzői. Központi Statisztikai Hivatal, Budapest. p. 60.

http://www.ksh.hu/docs/hun/xftp/idoszaki/nepsz2011/nepsz_20_2011.pdf Letöltve: 2016. június 5 . 


\section{MELLÉKLETEK}


1. sz. melléklet

\section{KÉRDŐÍV FALUSI SZÁLLÁSADÓK RÉSZÉRE}

1. Település neve:

2. Válaszadó kora:

3. Válaszadó neme:

\begin{tabular}{|l|l|}
\hline Férfi & \\
\hline Nö & \\
\hline
\end{tabular}

4. Legmagasabb iskolai végzettsége:

\begin{tabular}{|l|l|}
\hline Alapfokú & \\
\hline Középfokú & \\
\hline Felsőfokú & \\
\hline
\end{tabular}

5. Rendelkezik-e turisztikai végzettséggel?

\begin{tabular}{|l|l|}
\hline Igen & \\
\hline Nem & \\
\hline
\end{tabular}

6. Ha igen, milyen szintű turisztikai végzettsége van?

\begin{tabular}{|l|l|}
\hline Tanfolyam (pl. OKJ-s) & \\
\hline Középiskola & \\
\hline Felsőfokú tanulmányok & \\
\hline Egyéb: & \\
\hline
\end{tabular}

7. Rendelkezik-e nyelvismerettel?

\begin{tabular}{|l|l|}
\hline Igen & \\
\hline Nem & \\
\hline
\end{tabular}

8. Ha igen, milyen szintü nyelvismerete van? (Kérem jelölje x-szel a megfelelő rovatban!)

\begin{tabular}{|l|l|l|l|}
\hline & Alapfokú & Középfokú & Felsőfokú \\
\hline Angol & & & \\
\hline Német & & & \\
\hline Francia & & & \\
\hline Spanyol & & & \\
\hline Orosz & & & \\
\hline Egyéb: & & & \\
$\ldots . . . . . . .$. & & & \\
\hline
\end{tabular}


9. Kérem adja meg, milyen fajtájú falusi szálláshellyel rendelkezik?

\begin{tabular}{|l|l|}
\hline Vendégszoba & \\
\hline Lakrész & \\
\hline Vendégház & \\
\hline Sátorozóhely & \\
\hline Egyéb: & \\
\hline
\end{tabular}

10. Kérem adja meg, milyen minőségi kategóriába tartozik az Ön szálláshelye!

\begin{tabular}{|l|l|}
\hline 1 napraforgós & \\
\hline 2 napraforgós & \\
\hline 3 napraforgós & \\
\hline 4 napraforgós & \\
\hline
\end{tabular}

11. Szakosodott-e az Ön szálláshelye?

\begin{tabular}{|l|l|}
\hline Igen & \\
\hline Nem & \\
\hline
\end{tabular}

12. Ha igen, milyen szakosodása van?

\begin{tabular}{|l|l|}
\hline Bioporta/Ökoporta & \\
\hline Egészségporta & \\
\hline $\begin{array}{l}\text { Kerekes és } \\
\text { mozgáskorlátozottakat fogadó } \\
\text { vendégház }\end{array}$ & \\
\hline $\begin{array}{l}\text { Bébi- és gyermekbarát } \\
\text { vendégház }\end{array}$ & \\
\hline Aktív üdülés falusi portán & \\
\hline Üdülés lovas tanyán & \\
\hline $\begin{array}{l}\text { Üdülés boros/pálinkás } \\
\text { gazdánál }\end{array}$ & \\
\hline Hagyományok portája & \\
\hline Falusi életmód ifjúsági porta & \\
\hline
\end{tabular}

13. A szállásadó (azaz Ön) a vendégekkel egy ingatlanban lakik-e?

\begin{tabular}{|l|l|}
\hline Igen & \\
\hline Nem & \\
\hline
\end{tabular}

14. A szállásadáson kívül milyen turisztikai szolgáltatást kínál még vendégeinek? (Több válasz is lehetséges!)

\begin{tabular}{|l|l|}
\hline $\begin{array}{l}\text { Falusi vendégasztal } \\
\text { szolgáltatás }\end{array}$ & \\
\hline Reggeliztetés & \\
\hline Kemence & \\
\hline Szabadtéri sütés-fózés & \\
\hline
\end{tabular}




\begin{tabular}{|l|l|}
\hline $\begin{array}{l}\text { Szórakoztató beltéri játékok } \\
\text { (pl. asztalitenisz, biliárd) }\end{array}$ & \\
\hline $\begin{array}{l}\text { Szabadtéri sporteszközök, } \\
\text { játékok }\end{array}$ & \\
\hline Játszóudvar, játszósarok & \\
\hline $\begin{array}{l}\text { Hagyományos gazdálkodás } \\
\text { bemutatása }\end{array}$ & \\
\hline $\begin{array}{l}\text { Vidéki élethez kapcsolódó } \\
\text { tevékenységek } \\
\text { pincelátogatás, stb.) }\end{array}$ & \\
\hline Biogazdálkodás bemutatása & \\
\hline $\begin{array}{l}\text { Gyümölcsöskert, konyhakert } \\
\text { Állatsimogató/Ismerkedés a } \\
\text { háziállatokkal }\end{array}$ & \\
\hline Kézmúves programok & \\
\hline Kerékpárkölcsönzés & \\
\hline Horgászat \\
\hline Vadászat \\
\hline $\begin{array}{l}\text { Lovas } \\
\text { szolgáltatások }\end{array}$ \\
\hline Szakképzett túravezetés & \\
\hline Szauna & \\
\hline Fürdó medence & \\
\hline $\begin{array}{l}\text { Mozgássérülteket } \\
\text { szoba }\end{array}$ & \\
\hline $\begin{array}{l}\text { Egyéb } \\
\text {..................................... }\end{array}$ \\
\hline
\end{tabular}

15. Kínál-e vendégeinek olyan programokat, amelyeket nem Önnél, hanem más szolgáltatónál vehetnek igénybe?

\begin{tabular}{|l|l|}
\hline Igen & \\
\hline Nem & \\
\hline
\end{tabular}

16. Ha igen, milyen programot?

\begin{tabular}{|l|l|}
\hline $\begin{array}{l}\text { Falusi vendégasztal } \\
\text { szolgáltatás }\end{array}$ & \\
\hline Reggeliztetés & \\
\hline $\begin{array}{l}\text { Hagyományos gazdálkodás } \\
\text { bemutatása }\end{array}$ & \\
\hline $\begin{array}{l}\text { Vidéki élethez kapcsolódó } \\
\text { tevékenységek (szüret, } \\
\text { pincelátogatás, stb.) }\end{array}$ & \\
\hline Biogazdálkodás bemutatása & \\
\hline \begin{tabular}{l} 
Gyümölcsöskert, konyhakert \\
\hline $\begin{array}{l}\text { Állatsimogató/Ismerkedés a } \\
\text { háziállatokkal }\end{array}$
\end{tabular} & \\
\hline Kézmúves programok & \\
\hline
\end{tabular}




\begin{tabular}{|c|c|}
\hline Kerékpárkölcsönzés & \\
\hline Horgászat & \\
\hline Vadászat & \\
\hline $\begin{array}{ll}\text { Lovas } & \text { programok, } \\
\text { szolgáltatások } & \end{array}$ & \\
\hline Szakképzett túravezetés & \\
\hline $\begin{array}{ll}\text { Egyéb } & \text { szolgáltatás: } \\
\ldots \ldots \ldots \ldots \ldots \ldots \ldots & \ldots \ldots \ldots \ldots \ldots\end{array}$ & \\
\hline
\end{tabular}

17. A vidéki/falusi turisztikai szolgáltatást főállásban, életvitelszerüen végzi?

\begin{tabular}{|l|l|}
\hline Igen & \\
\hline Nem & \\
\hline
\end{tabular}

18. Ha igen, milyen formában?

\begin{tabular}{|l|l|}
\hline $\begin{array}{l}\text { Falusi vendéglátóként } \\
\text { (magánszemélyként) }\end{array}$ & \\
\hline Vállalkozóként & \\
\hline Gazdasági társaságként & \\
\hline Egyéb: .......................... & \\
\hline
\end{tabular}

19. Ha nem fóállású, milyen jogviszony mellett folytat a vidéki/falusi turisztikai szolgáltatást?

\begin{tabular}{|l|l|}
\hline Tanuló/hallgató & \\
\hline $\begin{array}{l}\text { Őstermeló, családi } \\
\text { gazdálkodó }\end{array}$ & \\
\hline Vállalkozó & \\
\hline Alkalmazott & \\
\hline Nyugdíjas & \\
\hline Egyéb: .......................... & \\
\hline
\end{tabular}

20. Ha nem fóállású, milyen tevékenységet folytat a vidéki/falusi turisztikai szolgáltatás nyújtásán kívül?

\begin{tabular}{|l|l|}
\hline Mezőgazdasági & \\
\hline Ipari & \\
\hline Más szolgáltatás & \\
\hline Egyéb: .......................... & \\
\hline
\end{tabular}


21. Milyen indíttatásból kezdte el jelenlegi vidéki/falusi turisztikai szolgáltatói tevékenységét? Tegyen x-et a megfelelő rovatba!

\begin{tabular}{|l|l|l|l|l|}
\hline & $\begin{array}{l}\text { Egyáltalán } \\
\text { nem igaz }\end{array}$ & $\begin{array}{l}\text { Részben } \\
\text { igaz }\end{array}$ & $\begin{array}{l}\text { Nagy } \\
\text { mértékben } \\
\text { igaz }\end{array}$ & $\begin{array}{l}\text { Teljes } \\
\text { mértékben } \\
\text { igaz }\end{array}$ \\
\hline Kényszerból & & & & \\
\hline $\begin{array}{l}\text { A } \\
\text { szolgáltatásnyújtás } \\
\text { feltételei adottak } \\
\text { voltak }\end{array}$ & & & \\
\hline $\begin{array}{l}\text { A szolgáltatásból } \\
\text { származó } \\
\text { kiegészítő } \\
\text { jövedelemszerzés } \\
\text { lehetősége miatt }\end{array}$ & & & & \\
\hline $\begin{array}{l}\text { A szolgáltatás } \\
\text { magas } \\
\text { jövedelmezósége } \\
\text { miatt }\end{array}$ & & & & \\
\hline
\end{tabular}

22. Részt vett-e már vidéki/falusi turizmussal kapcsolatos képzésen?

\begin{tabular}{|l|l|}
\hline Igen & \\
\hline Nem & \\
\hline
\end{tabular}

23. Ha igen, akkor milyen témájú képzésen?

\begin{tabular}{|l|l|}
\hline Nyelvi képzés & \\
\hline Pályázatírás & \\
\hline $\begin{array}{l}\text { Vendéglátással kapcsolatos } \\
\text { ismeretek }\end{array}$ & \\
\hline $\begin{array}{l}\text { Szállásszolgáltatással } \\
\text { kapcsolatos ismeretek }\end{array}$ & \\
\hline $\begin{array}{l}\text { Programszervezéssel } \\
\text { kapcsolatos ismeretek }\end{array}$ & \\
\hline Egyéb: ................................ & \\
\hline
\end{tabular}

24. Hány különálló szálláshelyet müködtet?

\begin{tabular}{|l|l|}
\hline 1 & \\
\hline $\mathbf{2 - 3}$ & \\
\hline $\begin{array}{l}\text { Több } \\
\text { mint 3 }\end{array}$ & \\
\hline
\end{tabular}

25. Kérem adja meg szállásférőhelyei (ágyak) számát! db 
26. Képvisel-e valamilyen építészeti értéket az Ön szálláshelye?

27. Ha igen, milyen értéket?

\begin{tabular}{|l|l|}
\hline Igen & \\
\hline Nem & \\
\hline
\end{tabular}

\begin{tabular}{|l|l|}
\hline Népi múemlék & \\
\hline Korhúen felújított épület & \\
\hline $\begin{array}{l}\text { Népi építészeti jegyeket viselö } \\
\text { épület }\end{array}$ & \\
\hline Egyéb: ............................. & \\
\hline
\end{tabular}

28. Szolgáltatásaival mely hónapokban áll a vendégek rendelkezésére?

\begin{tabular}{|l|l|}
\hline Január & \\
\hline Február & \\
\hline Március & \\
\hline Április & \\
\hline Május & \\
\hline Június & \\
\hline Július & \\
\hline Augusztus & \\
\hline Szeptember & \\
\hline Október & \\
\hline November & \\
\hline December & \\
\hline
\end{tabular}

29. Milyen belső erőforrásokkal rendelkezik az Ön települése? (Értékelje 1-től 5-ig: 1 - jelentéktelen, 2 - kevésbé jelentős, 3 - átlagos, 4 - inkább jelentős, 5 - nagyon jelentős) Tegyen x-et a megfelelö rovatba!

\begin{tabular}{|l|l|l|l|l|l|}
\hline \multicolumn{1}{|c|}{ Belső eröforrások } & & & & & \\
\hline $\begin{array}{l}\text { Tájkép, természetvédelmi területek, természeti } \\
\text { értékek }\end{array}$ & & & & & \\
\hline Állat- és növényvilág & & & & & \\
\hline Felszíni- és felszín alatti vizek & & & & & \\
\hline Termőföld & & & & & \\
\hline Erdővagyon & & & & & \\
\hline $\begin{array}{l}\text { Tradícionális mezőgazdasági kultúra, helyi } \\
\text { élelmiszerek }\end{array}$ & & & & & \\
\hline Kulturális örökség, hagyományok, népszokások & & & & & \\
\hline Kézmúves termékek & & & & & \\
\hline Történelmi épületek, múemlékek & & & & & \\
\hline Jó kapcsolat a térségi települések között & & & & & \\
\hline A helyben élők erős kötődése a településhez, térséghez & & & & & \\
\hline Vállalkozói szemlélet & & & & & \\
\hline Versenyképes tudással rendelkező humán erőforrás & & & & & \\
\hline
\end{tabular}




\begin{tabular}{|l|l|l|l|l|l|}
\hline Hagyományos értékkel bíró vidéki közösségek & & & & & \\
\hline Kreatív emberek & & & & & \\
\hline Nagy múltú vidékturisztikai rendezvények, fesztiválok & & & & & \\
\hline Vidéki életmód & & & & & \\
\hline
\end{tabular}

30. Ön szerint mennyire fontos eleme a helyi kultúra települése turisztikai kínálatának?

\begin{tabular}{|l|l|}
\hline Meghatározó része & \\
\hline Fontos része & \\
\hline Kevésbé fontos része & \\
\hline Nem jelentős & \\
\hline
\end{tabular}

31. Értékelje a helyi épített és kulturális örökség elemeit az Ön településén! (1 jelentéktelen, 2 - kevésbé jelentős, 3 - átlagos, 4 - inkább jelentős, 5 - nagyon jelentős) Tegyen x-et a megfelelő rovatba!

\begin{tabular}{|l|l|l|l|l|l|}
\hline \multicolumn{1}{|c|}{ Helyi kultúra elemei } & & & & & \\
\hline Kastély, kúria & & & & & \\
\hline Templom & & & & & \\
\hline Kolostor, zarándokhely & & & & & \\
\hline Vár & & & & & \\
\hline Más jellegú múemlék épület (pl. malom) & & & & & \\
\hline Védett természeti értékek & & & & & \\
\hline Híres emberekkel kapcsolatos emlékhely & & & & & \\
\hline Gasztronómia, tájra jellemzó ételek, italok & & & & & \\
\hline Népi építészet & & & & & \\
\hline Kézmúves termékek & & & & & \\
\hline Hagyományos mesterségek megléte & & & & & \\
\hline Fesztiválok, rendezvények & & & & & \\
\hline $\begin{array}{l}\text { Hagyományos mezógazdasági szaktudás megléte (Az } \\
\text { itt éloók hozzáértése a növénytermesztéshez és az } \\
\text { állattenyésztéshez) }\end{array}$ & & & & & \\
\hline
\end{tabular}

32. Együttműködik-e a településen más turisztikai szolgáltatókkal (szállásadó, vendéglátóhely, programszervező)?

\begin{tabular}{|l|l|}
\hline Igen & \\
\hline Nem & \\
\hline
\end{tabular}

33. Ha igen, kérem értékelje az együttmüködést! (1 - jelentéktelen, 5 nagyon jelentős)

\begin{tabular}{|l|l|}
\hline 1 - jelentéktelen & \\
\hline 2 - kevésbé jelentős & \\
\hline 3 - átlagos & \\
\hline
\end{tabular}




\begin{tabular}{|l|l|}
\hline $4-$ inkább jelentôs & \\
\hline $5-$ nagyon jelentős & \\
\hline
\end{tabular}

34. Együttmüködik-e a településen más, nem turisztikai szolgáltatókkal (kistermelők, erdészet, Nemzeti Park, stb.)?

\begin{tabular}{|l|l|}
\hline Igen & \\
\hline Nem & \\
\hline
\end{tabular}

35. Ha igen, kérem értékelje az együttmúködést! (1 - jelentéktelen, 5 nagyon jelentős)

\begin{tabular}{|l|l|}
\hline $1-$ jelentéktelen & \\
\hline $2-$ kevésbé jelentős & \\
\hline 3 - átlagos & \\
\hline $4-$ inkább jelentős & \\
\hline $5-$ nagyon jelentős & \\
\hline
\end{tabular}

36. Tagja-e LEADER Helyi Akciócsoportnak?

\begin{tabular}{|l|l|}
\hline Igen & \\
\hline Nem & \\
\hline
\end{tabular}

37. Az Ön véleménye szerint mennyire van meghatározó szerepe a turizmusnak települése gazdasági-társadalmi életében?

\begin{tabular}{|l|l|}
\hline Meghatározó & \\
\hline Kiegészítő tevékenység & \\
\hline Nem jelentős & \\
\hline
\end{tabular}

38. Ön szerint mennyire van meghatározó szerepe általában a turizmusnak az Alföld gazdasági-társadalmi életében?

\begin{tabular}{|l|l|}
\hline $\begin{array}{l}\text { Meghatározó a település } \\
\text { gazdaságában }\end{array}$ & \\
\hline $\begin{array}{l}\text { Kiegészító tevékenység sok } \\
\text { család számára más } \\
\text { tevékenység mellett }\end{array}$ & \\
\hline $\begin{array}{l}\text { Kiegészítő tevékenység } \\
\text { néhány család számára más } \\
\text { tevékenység mellett }\end{array}$ & \\
\hline $\begin{array}{l}\text { Nem jelentős a település } \\
\text { gazdaságában }\end{array}$ & \\
\hline
\end{tabular}

39. Ön szerint várhatóan milyen pozitív hatásai lesznek a turizmusnak a jövőben?

\begin{tabular}{|l|l|}
\hline Infrastrukturális fejlesztések & \\
\hline Munkahelyteremtés & \\
\hline A turizmusban & \\
\hline
\end{tabular}




\begin{tabular}{|l|l|}
\hline $\begin{array}{l}\text { alkalmazottak számának } \\
\text { növekedése }\end{array}$ & \\
\hline $\begin{array}{l}\text { A térség ismertségének } \\
\text { növekedése }\end{array}$ & \\
\hline Egyéb: .............. & \\
\hline Nem lesz pozitív hatása & \\
\hline
\end{tabular}

40. Ön szerint várhatóan milyen negatív hatásai lesznek a turizmusnak a jövőben?

\begin{tabular}{|l|l|}
\hline $\begin{array}{l}\text { Természeti környezet } \\
\text { károsodása }\end{array}$ & \\
\hline $\begin{array}{l}\text { Helyi lakosság életterének } \\
\text { csökkenése }\end{array}$ & \\
\hline Zajszennyezés & \\
\hline $\begin{array}{l}\text { Büncselekmények számának } \\
\text { növekedése }\end{array}$ & \\
\hline Egyéb: ............. & \\
\hline Nem lesz negatív hatása & \\
\hline
\end{tabular}

41. Fejleszttette-e szolgáltatásait az elmúlt 10 évben?

\begin{tabular}{|l|l|}
\hline Igen & \\
\hline Nem & \\
\hline
\end{tabular}

42. Ha igen, milyen jellegü fejlesztéseket valósított meg?

\begin{tabular}{|l|l|}
\hline $\begin{array}{l}\text { Szolgáltatás minőségének } \\
\text { fejlesztése }\end{array}$ & \\
\hline $\begin{array}{l}\text { Szolgáltatások körének } \\
\text { bővítése }\end{array}$ & \\
\hline Szállásférőhelyek bővítése & \\
\hline Technológiai fejlesztés & \\
\hline Humán erőforrás fejlesztés & \\
\hline Egyéb: ............... & \\
\hline
\end{tabular}

43. Tervez-e fejlesztést a következő 5 évben?

\begin{tabular}{|l|l|}
\hline Igen & \\
\hline Nem & \\
\hline
\end{tabular}

44. Ha, igen, milyen jellegü fejlesztéseket tervez?

\begin{tabular}{|l|l|}
\hline $\begin{array}{l}\text { Szolgáltatás minőségének } \\
\text { fejlesztése }\end{array}$ & \\
\hline $\begin{array}{l}\text { Szolgáltatások körének } \\
\text { bővítése }\end{array}$ & \\
\hline Szállásférőhelyek bővítése & \\
\hline Technológiai fejlesztés & \\
\hline Humán erőforrás fejlesztés & \\
\hline
\end{tabular}


Egyéb: .............

45. Bizakodó-e tevékenysége jövőjét illetően?

\begin{tabular}{|l|}
\hline Igen \\
\hline .
\end{tabular}

Nem 
2. sz. melléklet:

\section{„Hagyományok-Ízek-Régiók” védjeggyel ellátott alföldi termékek}

\begin{tabular}{|c|c|c|c|}
\hline & $\begin{array}{c}\text { HÍR védjegyhasználó } \\
\text { termelő/elóállító és székhelye }\end{array}$ & $\begin{array}{c}\text { HÍR védjegyes termék } \\
\text { megnevezése }\end{array}$ & $\begin{array}{l}\text { Jogosultság } \\
\text { kezdete }\end{array}$ \\
\hline & Cukrászati termékek & & \\
\hline & Fekete Józsefné, Debrecen & Grillázstorta & 2010 \\
\hline . & $\begin{array}{l}\text { Toldi Miklós Élelmiszeripari } \\
\text { Szakképző Iskola és Kollégium, } \\
\text { Nagykőrös }\end{array}$ & Dobostorta, Zserbó & 2010 \\
\hline & Édesipari termékek & & \\
\hline & Csobán Mihályné, Csongrád & Csongrádi búzacsíramálé & 2011 \\
\hline & Füle Ferenc, Ceglédi & Ceglédi csírímálé & 2011 \\
\hline . & Radics László, Debrecen & $\begin{array}{l}\text { Debreceni mézeskalács } \\
\text { Debreceni vert mézes }\end{array}$ & 2011 \\
\hline & Friss vagy feldolgozott gyümölcs & & \\
\hline . & Körösi Miklósné, Penyige & $\begin{array}{l}\text { Penyigei szilvalekvár, } \\
\text { Somlekvár }\end{array}$ & 2010 \\
\hline . & Balku Gyuláné, Penyige & $\begin{array}{l}\text { Penyigei szilvalekvár, } \\
\text { Somlekvár }\end{array}$ & 2011 \\
\hline . & $\begin{array}{l}\text { Szomolya Község Önkormányzata, } \\
\text { Szomolya }\end{array}$ & $\begin{array}{l}\text { Szomolyai rövidszárú mézédes } \\
\text { fekete cseresznye }\end{array}$ & 2012 \\
\hline & Görög Erika, Kecskemét & $\begin{array}{l}\text { Napország Gyümölcse } \\
\text { kistermelői baracklekvár }\end{array}$ & 2013 \\
\hline 0. & Tranzit Dió Kft, Debrecen & $\begin{array}{l}\text { Milotai } 10 \text { dió } \\
\text { Zöld dió szirupban }\end{array}$ & 2013 \\
\hline & Friss, feldolgozott zöldség, gomba & & \\
\hline 1. & Univer Product Zrt, Kecskemét & $\begin{array}{l}\text { Erős Pista } \\
\text { Édes Anna } \\
\text { Piros Arany }\end{array}$ & 2010 \\
\hline 2. & Csanád és Térsége Gazdakör, Makó & $\begin{array}{l}\text { Makói zöldség/Makói hosszú } \\
\text { petrezselyemgyökér }\end{array}$ & 2015 \\
\hline & Fűszernövények, ízesítők & & \\
\hline 3. & Farkas András, Szeged & Füszerpaprika-őrlemény & 2011 \\
\hline 4. & Paprika Molnár Kft. Röszke & $\begin{array}{l}\text { Szegedi füszerpaprika- } \\
\text { örlemény }\end{array}$ & 2011 \\
\hline
\end{tabular}




\begin{tabular}{|c|c|c|c|}
\hline & Halászati termékek & & \\
\hline 5. & Szegedfish Kft Szeged & Szegedi tükrös ponty(filé) & 2011 \\
\hline & Húsok, húskészítmények & & \\
\hline 6. & Dónáth Élelmiszer Kft. Nagykőrös & Körösi sódar & 2010 \\
\hline 7. & Gyulahús Kft. Gyula & Gyulai kolbász & 2010 \\
\hline 8. & $\begin{array}{l}\text { Kiskunsági Hagyományőrző } \\
\text { Kézműves és Turisztikai } \\
\text { Egyesület, Kerekegyháza }\end{array}$ & Kiskunsági mangalica kolbász & 2011 \\
\hline 9. & Knyihár Mihály Békéscsaba & $\begin{array}{l}\text { Knyihár-féle } \\
\text { házikolbász(vastag) } \\
\text { Knyihár-féle } \\
\text { házikolbász(vékony } \\
\text { Cigánka }\end{array}$ & $\begin{array}{l}2012 \\
2012 \\
2013\end{array}$ \\
\hline & Italok, beleértve szörpök & & \\
\hline 0. & Lakatos Márton, Madaras & $\begin{array}{l}\text { Madarasi Pálinka, } \\
\text { Barackpálinka } \\
\text { Madarasi Pálinka, Birspálinka } \\
\text { Madarasi Pálinka, } \\
\text { Körtepálinka } \\
\text { Madarasi Pálinka, } \\
\text { Meggypálinka } \\
\text { Madarasi Pálinka, } \\
\text { Szilvapálinka } \\
\text { Madarasi Pálinka, } \\
\text { Szőlőpálinka }\end{array}$ & 2013 \\
\hline & Méz & & \\
\hline 1 & Zsibrita Pál, Mezőberény & $\begin{array}{l}\text { Selyemfú méz } \\
\text { Akácméz } \\
\text { Napraforgóméz } \\
\text { Repceméz }\end{array}$ & 2013 \\
\hline & Süitőipari termékek & & \\
\hline 2. & $\begin{array}{l}\text { Toldi Miklós Élelmiszeripari } \\
\text { Szakképző Iskola és Kollégium, } \\
\text { Nagykörös }\end{array}$ & $\begin{array}{l}\text { Orosházi banán } \\
\text { Paprikás kifli } \\
\text { Tepertős pogácsa }\end{array}$ & 2010 \\
\hline 3. & $\begin{array}{l}\text { Szegedikum Nonprofit Kft., } \\
\text { Szeged }\end{array}$ & Szegedi kenyér & 2010 \\
\hline 4. & $\begin{array}{l}\text { Civilek a Lakóhelyért Egyesület, } \\
\text { Hajdúböszörmény }\end{array}$ & $\begin{array}{l}\text { Böszörményi bobajka } \\
\text { Böszörményi darunyak } \\
\text { Böszörményi dübbencs } \\
\text { Böszörményi házikenyér } \\
\text { Böszörményi parasztkifli } \\
\text { Kapros kalács } \\
\text { Káposztás pogácsa }\end{array}$ & $\begin{array}{l}2011 \\
2011 \\
2011 \\
2011 \\
2011 \\
2011 \\
2011\end{array}$ \\
\hline
\end{tabular}




\begin{tabular}{|l|l|l|r|}
\hline & & Kenyérlángos & 2011 \\
& & Kött túrós béles & 2011 \\
& & Szilvás lepény & 2011 \\
& & Böszörményi lakodalmi béles & 2012 \\
& & $\begin{array}{l}\text { Mákos kukoricamálé } \\
\text { Ferdinánd tekercs } \\
\text { Kossuth-kifli (hajdúsági } \\
\text { hagyomány szerint) }\end{array}$ & 2012 \\
& & Kemencés borjúkötél & 2013 \\
\hline 5. & Csupor Ibolya, Szabadszállás & & 2014 \\
\hline & & & \\
\hline & Tájjellegú ételek: levesek, pörkölt, & & \\
\hline tésztafélék, egyéb & Karcagi Birkafözök Baráti & Karcagi birkapörkölt & \\
\hline 6. & Társasága, Karcag & & \\
\hline & & & \\
\hline & Tejtermékek & & \\
\hline \multirow{2}{*}{7.} & Gulyás Mihályné, Hajdúdororg & Gulyás gomolya & \\
\hline
\end{tabular}


3. sz. melléklet

\section{FOTÓMELLÉKLET ${ }^{15}$}

\footnotetext{
${ }^{15}$ Fotók: Tourinform Irodák, MT ZRt., szolgáltatói honlapok, valamint a szerző felvételei
} 


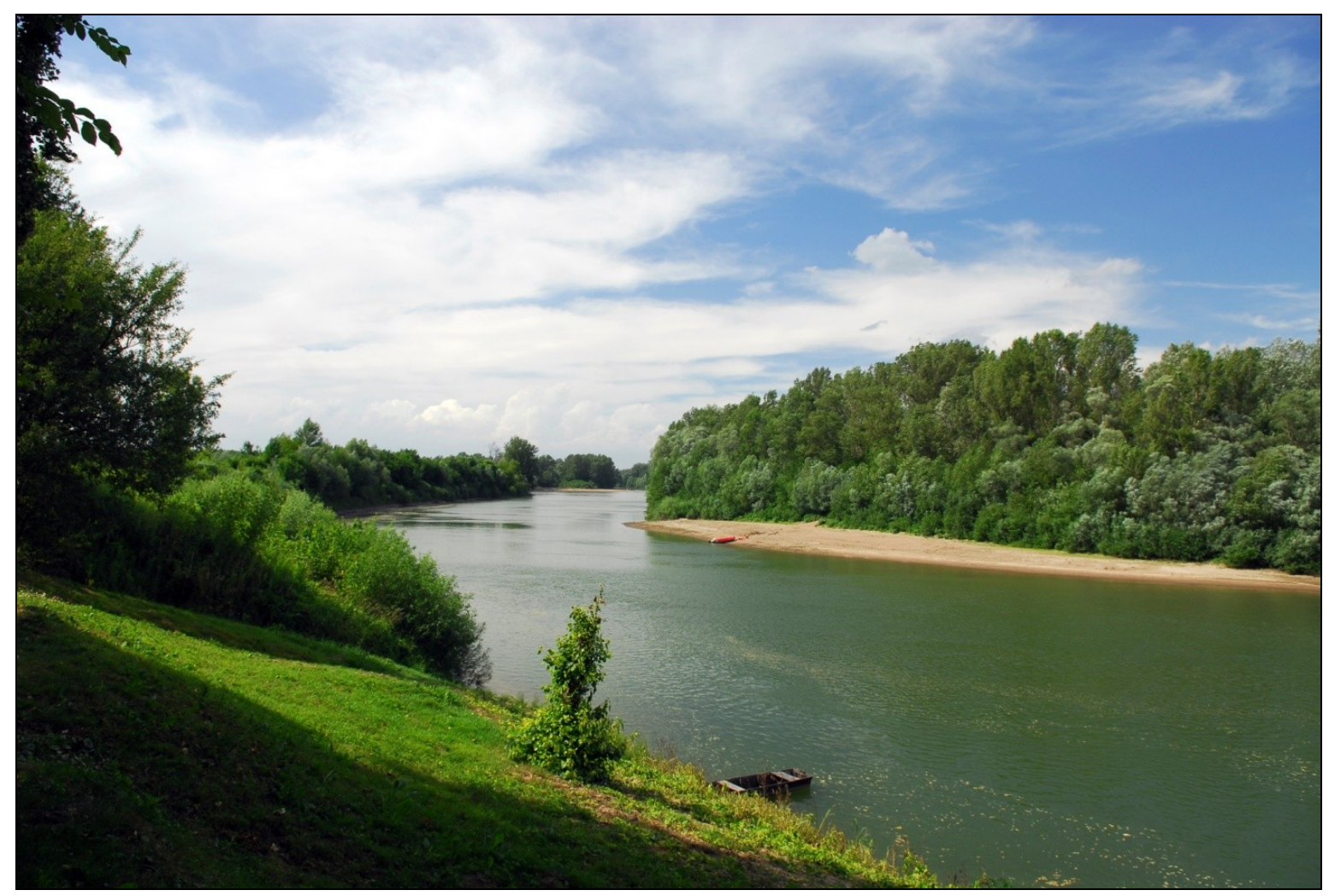

Felső-Tisza

Forrás: Tourinform Vásárosnamény

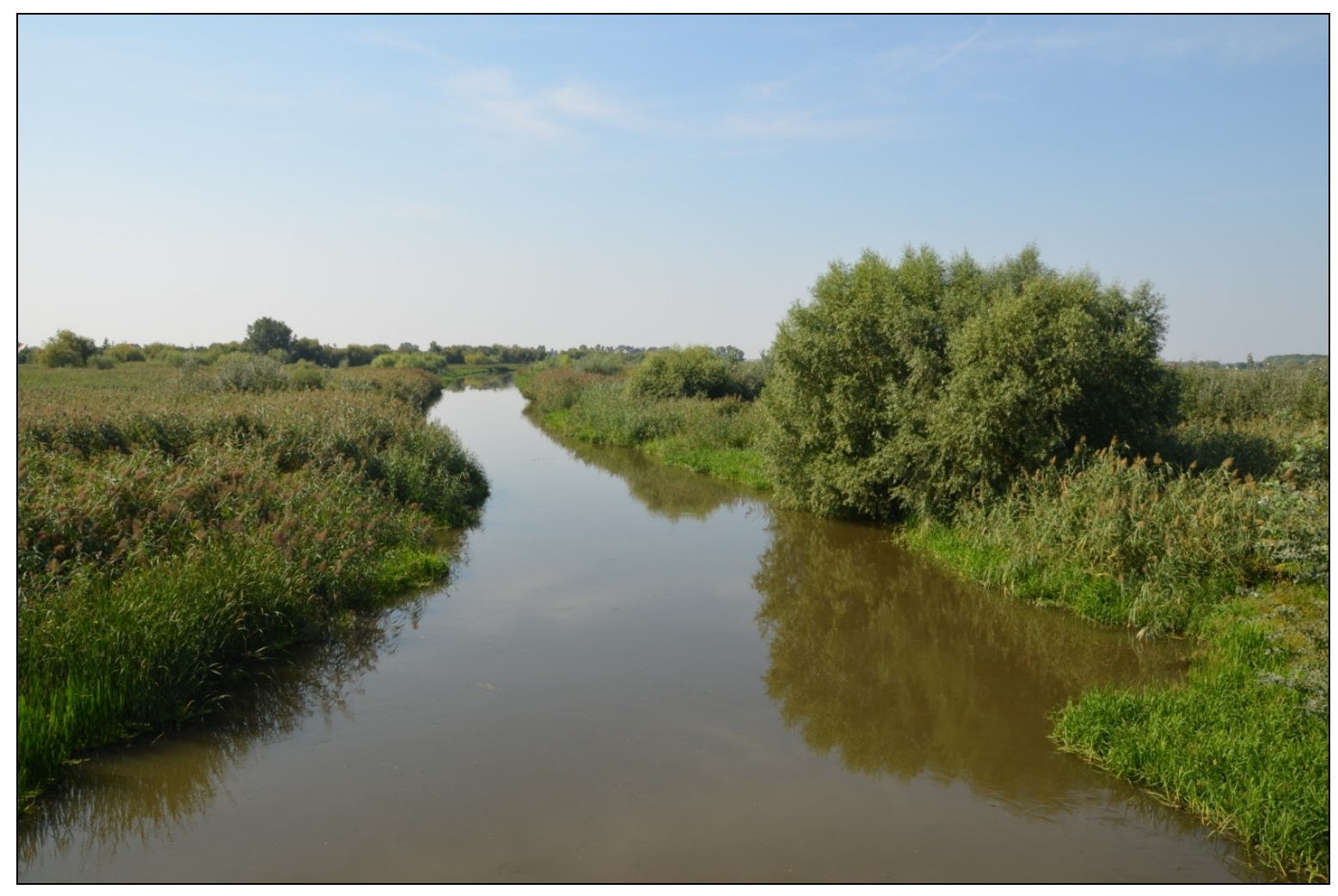

Hortobágy-Berettyó

Forrás: a szerző saját felvétele 


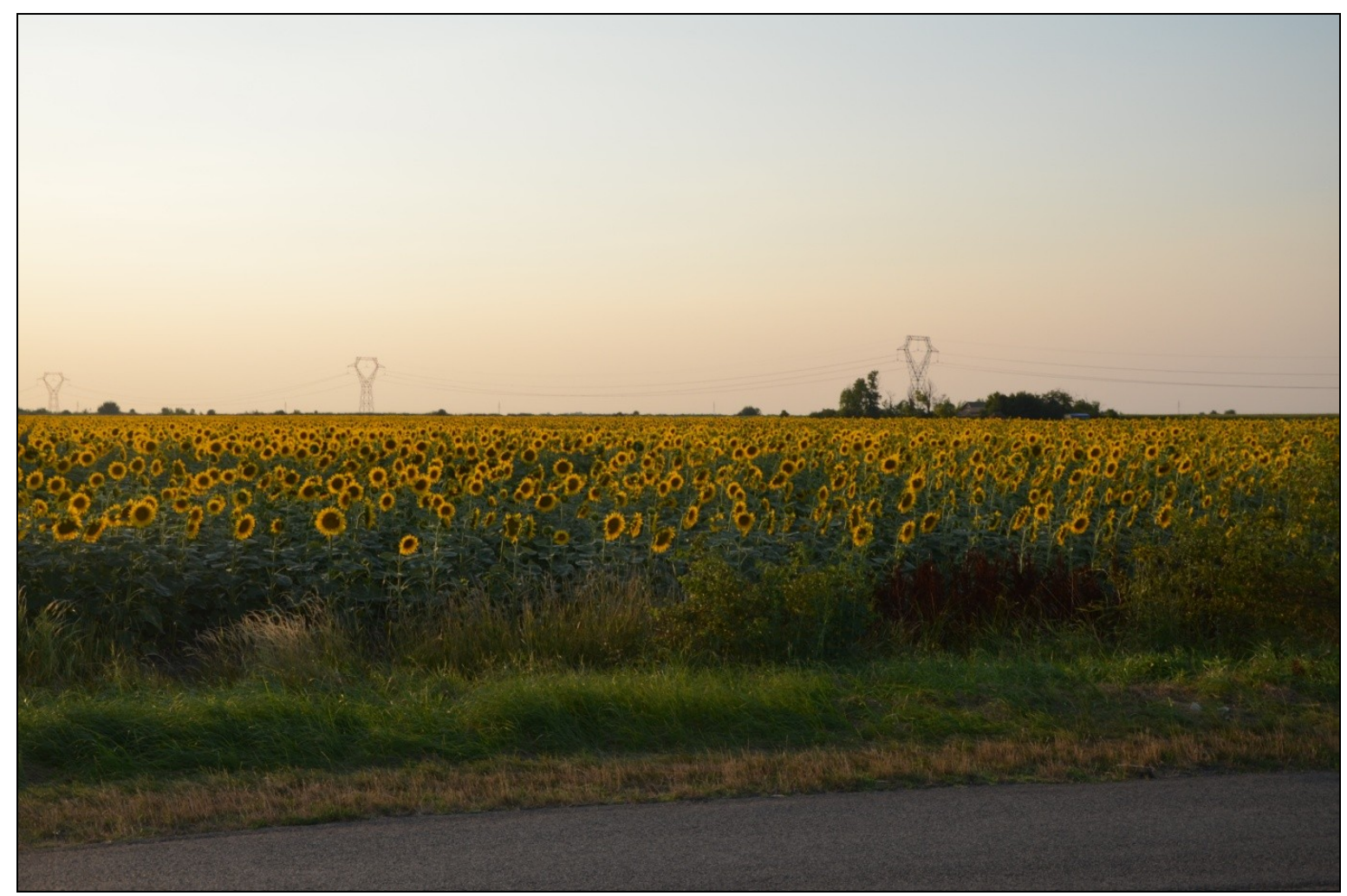

Alföldi táj napraforgótáblával

Forrás: a szerző saját felvétele

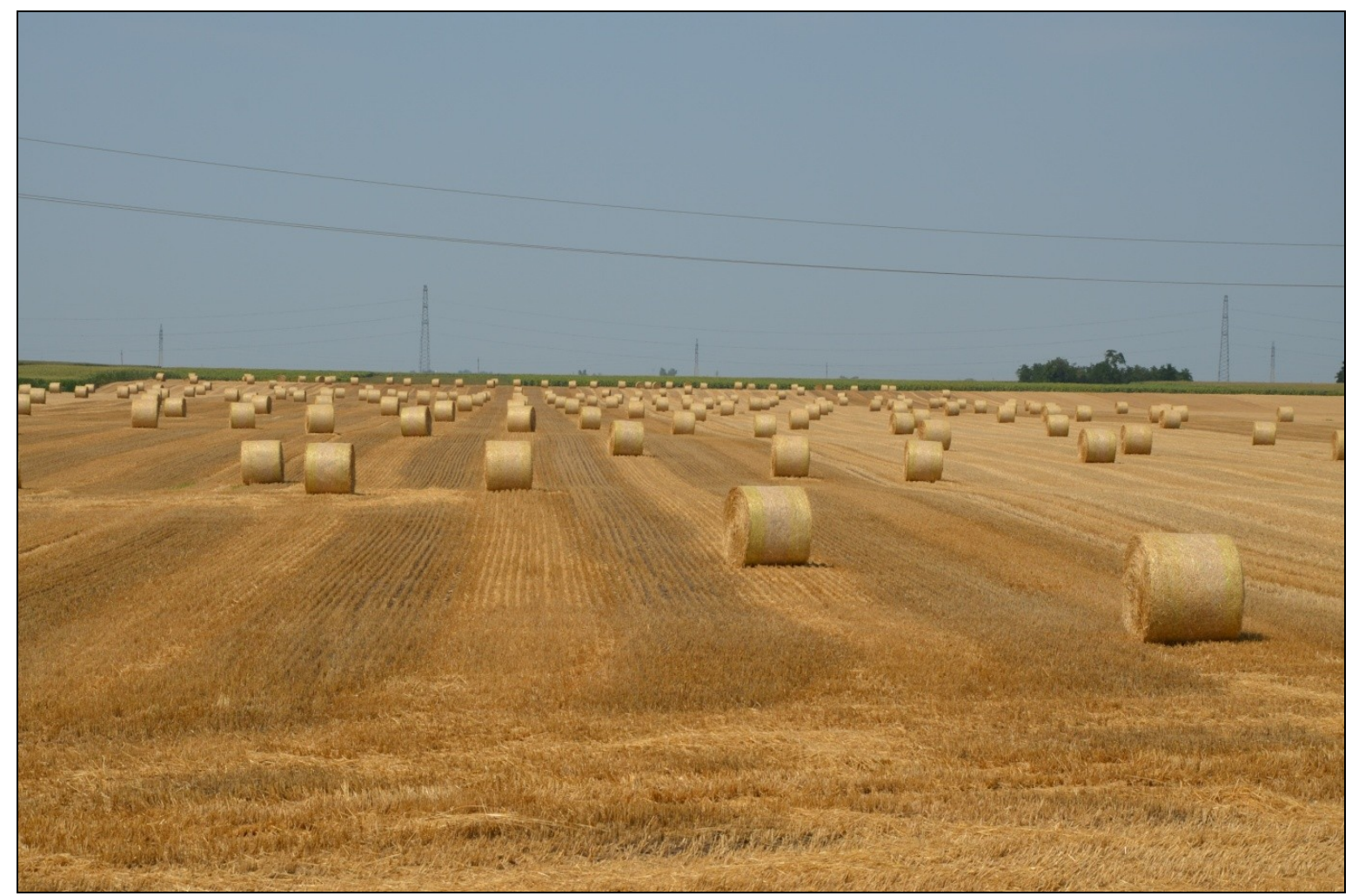

Alföldi táj aratás után

Forrás: a szerző saját felvétele 


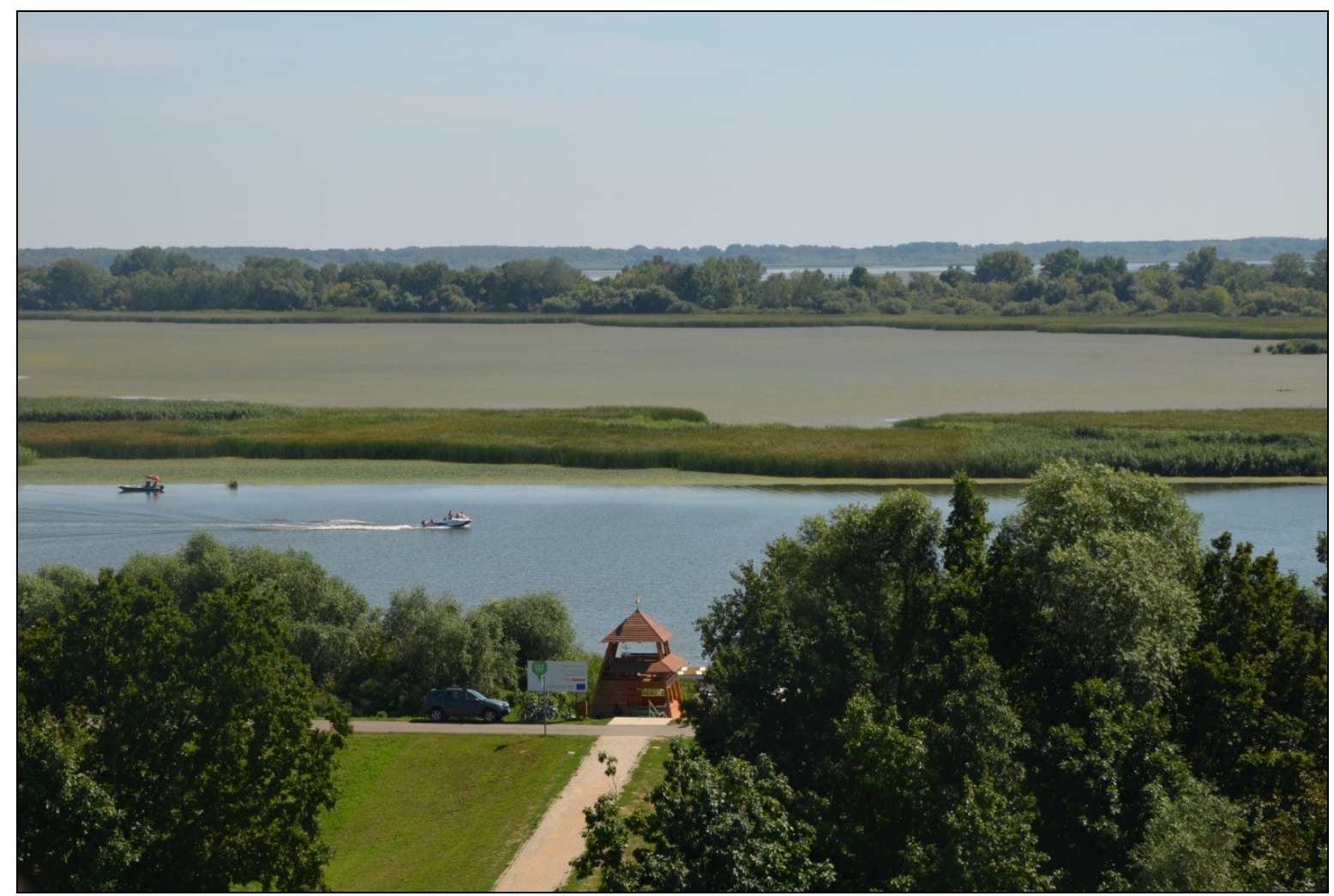

A Tisza-tó látképe

Forrás: a szerző saját felvétele

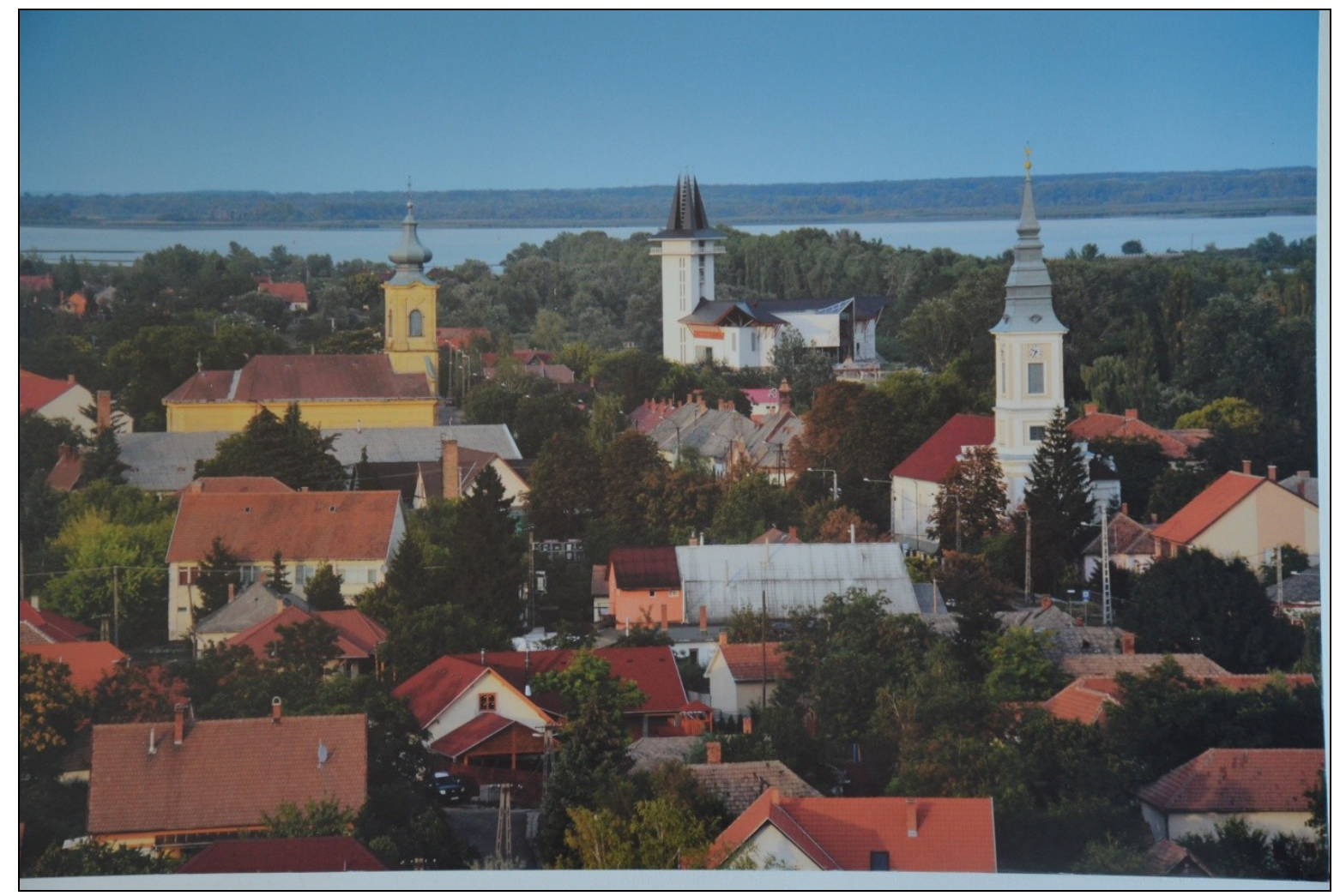

A Tisza-tavi Ökocentrum és a Tisza-tó Poroszlónál

Forrás: a szerző saját felvétele 


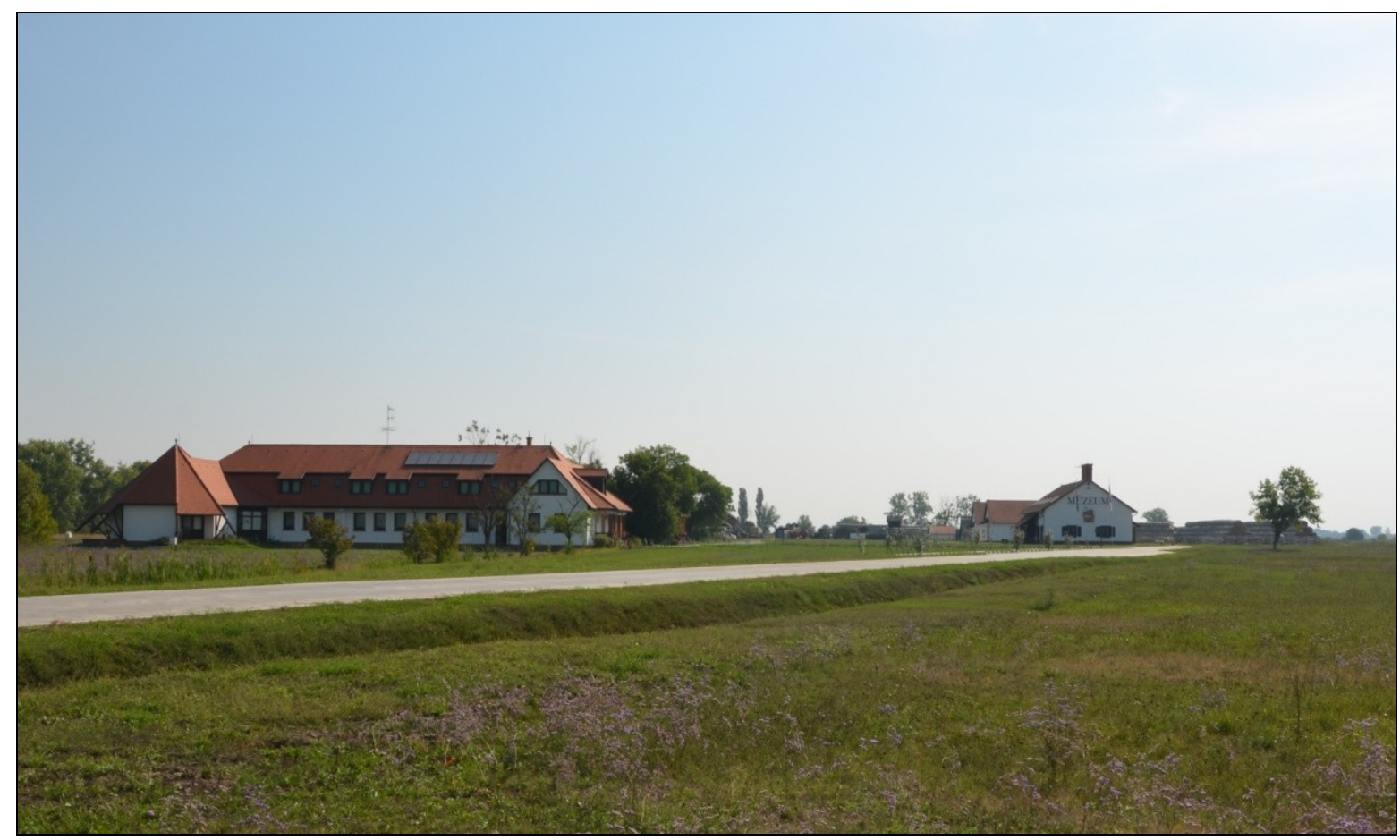

Dévavaványa-Réhely

Forrás: a szerző saját felvétele

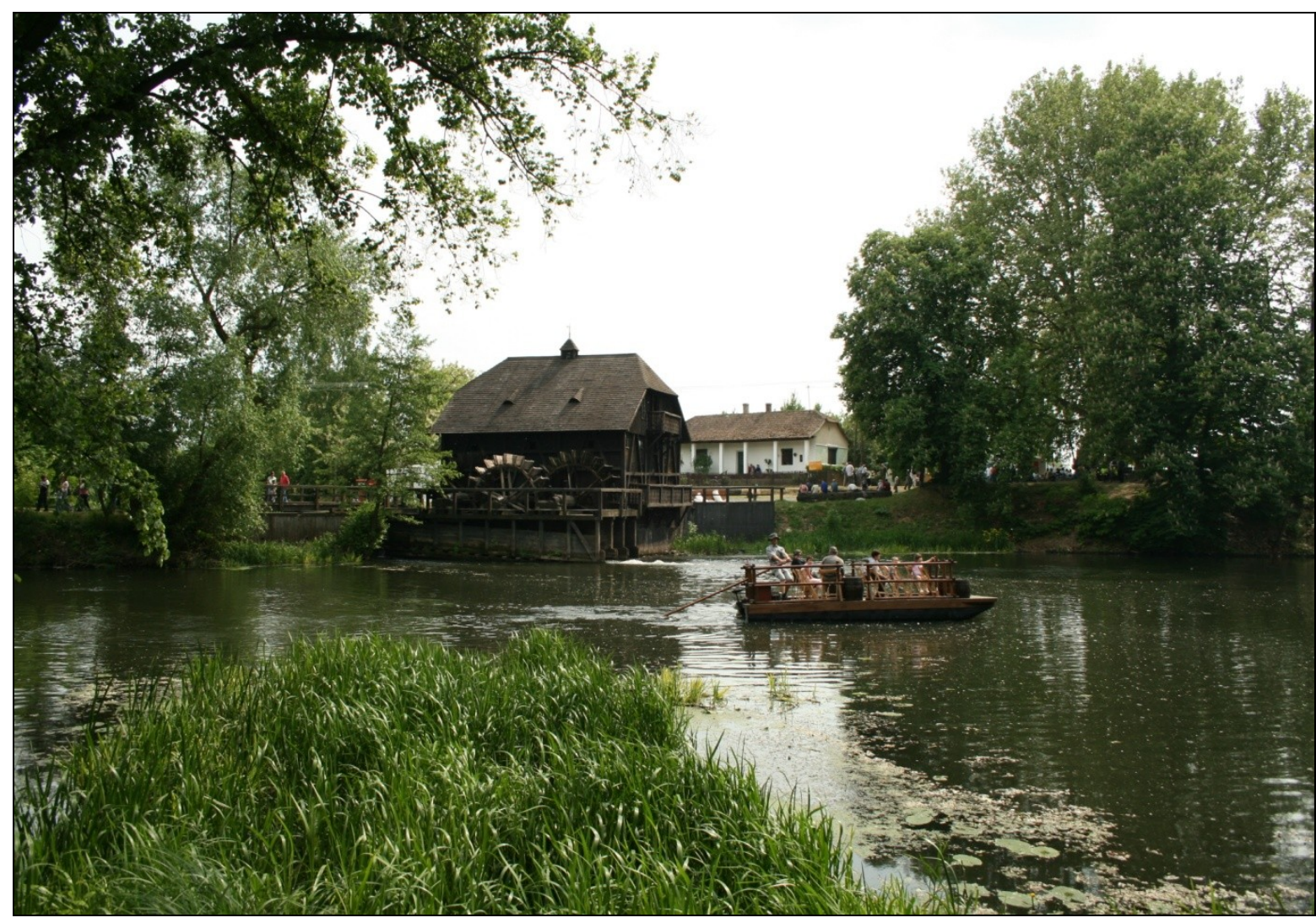

Túristvándi: Vízimalom

Forrás: Tourinform Vásárosnamény 


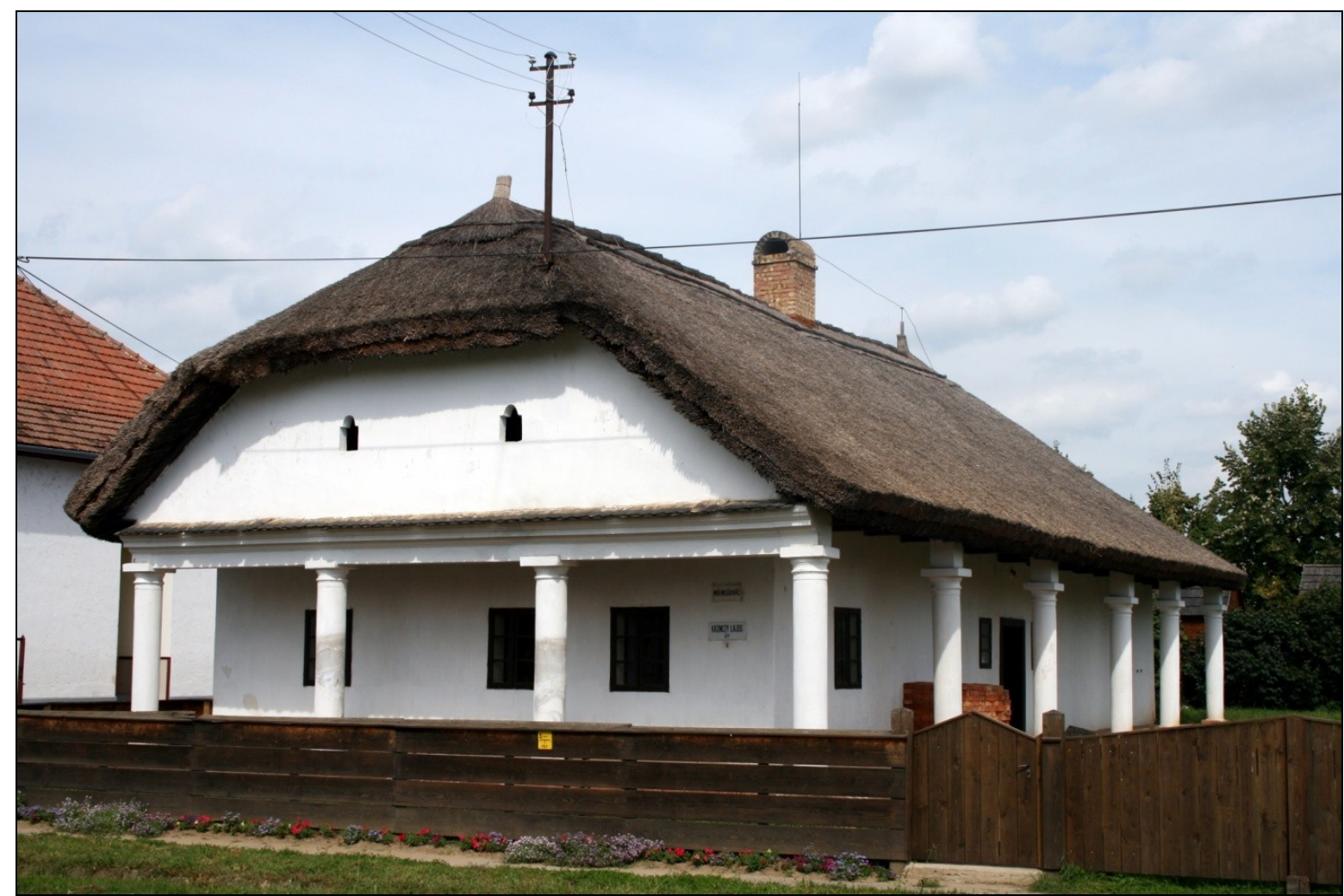

Vásárosnamény (Vitka): Egykori népi lakóház

Forrás: Tourinform Vásárosnamény

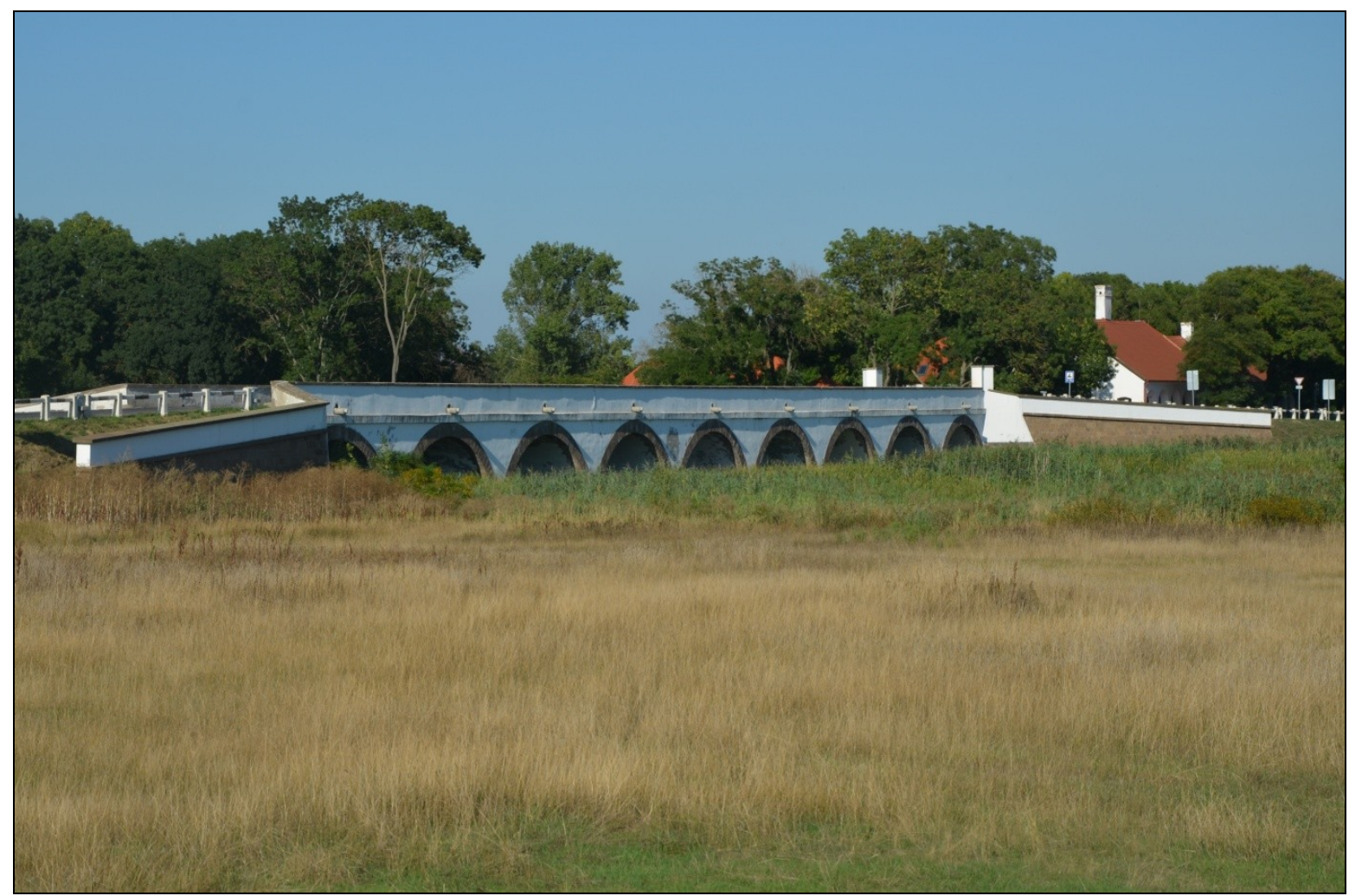

A hortobágyi Kilenclyukú híd

Forrás: a szerző saját felvétele 


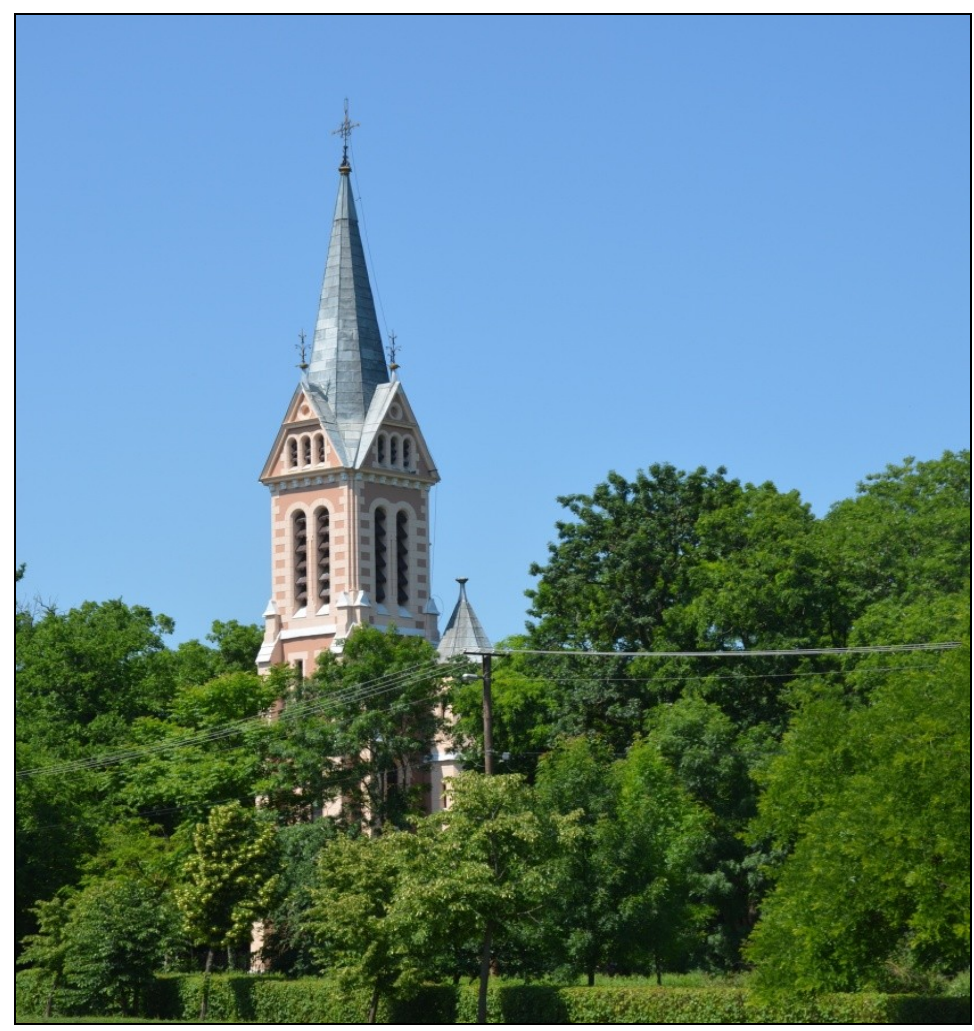

Római katolikus templom Nagymágocs

Forrás: a szerző saját felvétele

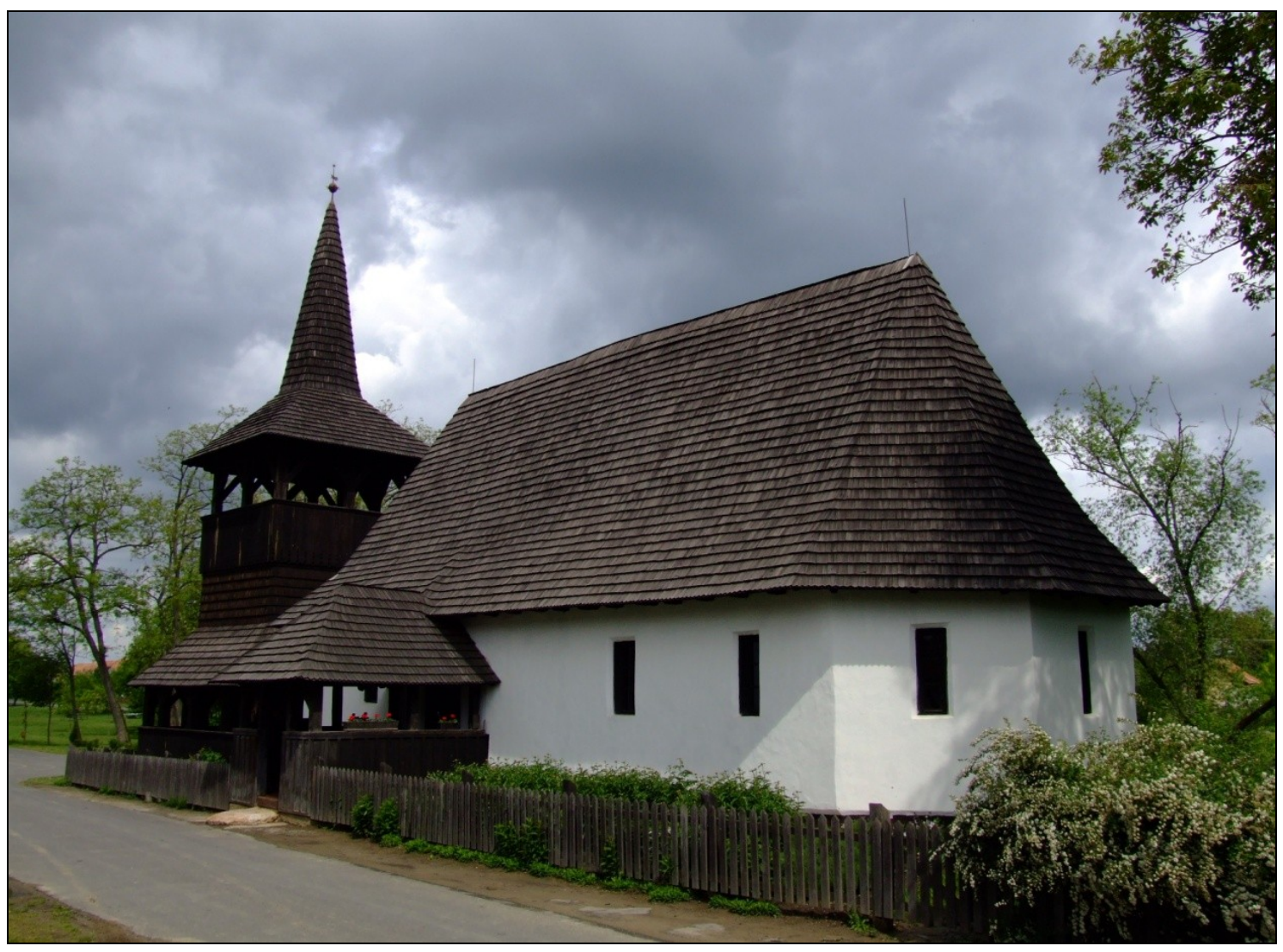

Református templom Tákos

Forrás: Tourinform Vásárosnamény 


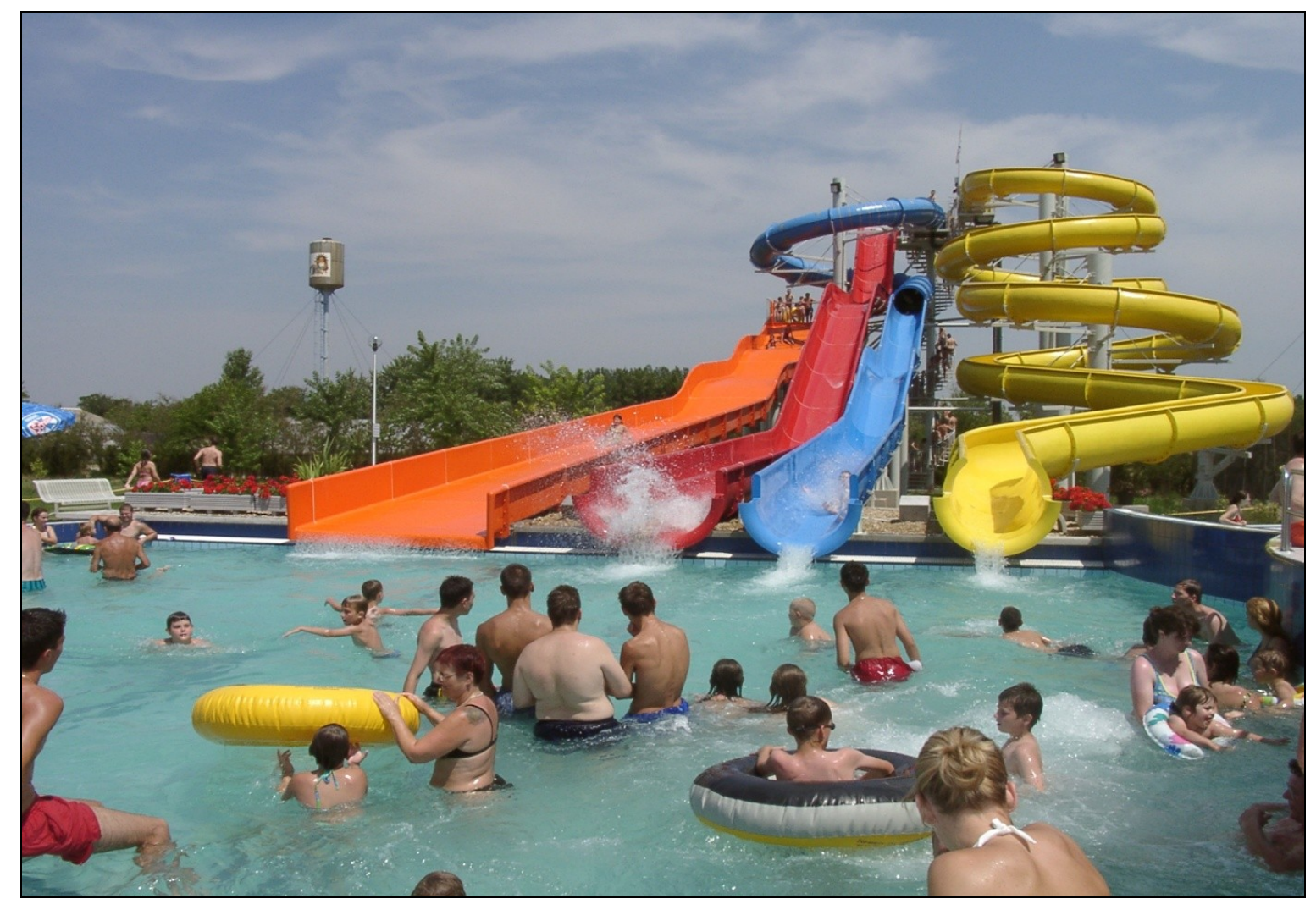

Jonathermal Gyógy- és Élményfürdő (Kiskunmajsa)

Forrás: MT Zrt.

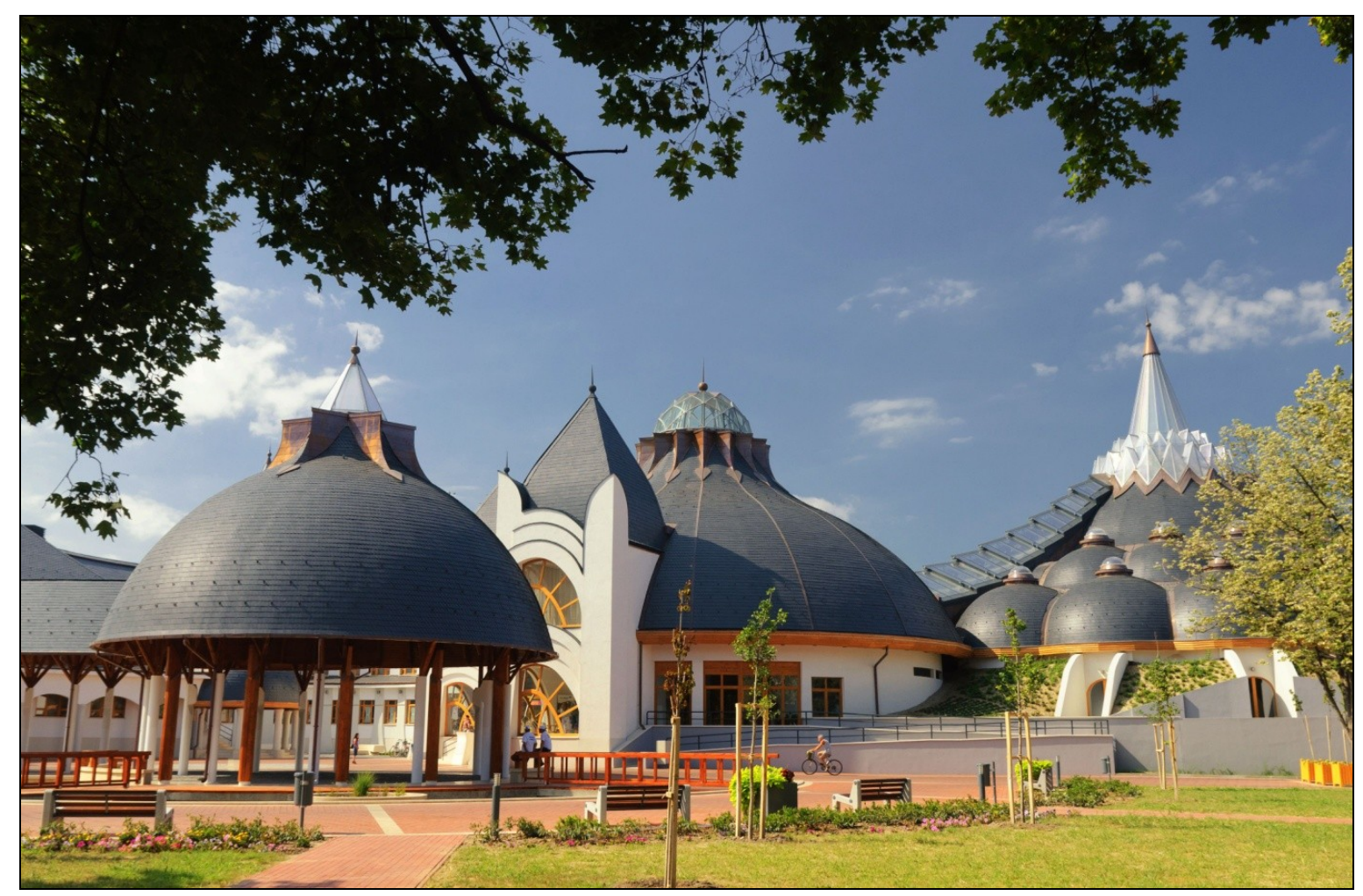

Hagymatikum fürdő (Makó)

Forrás: MT Zrt. 


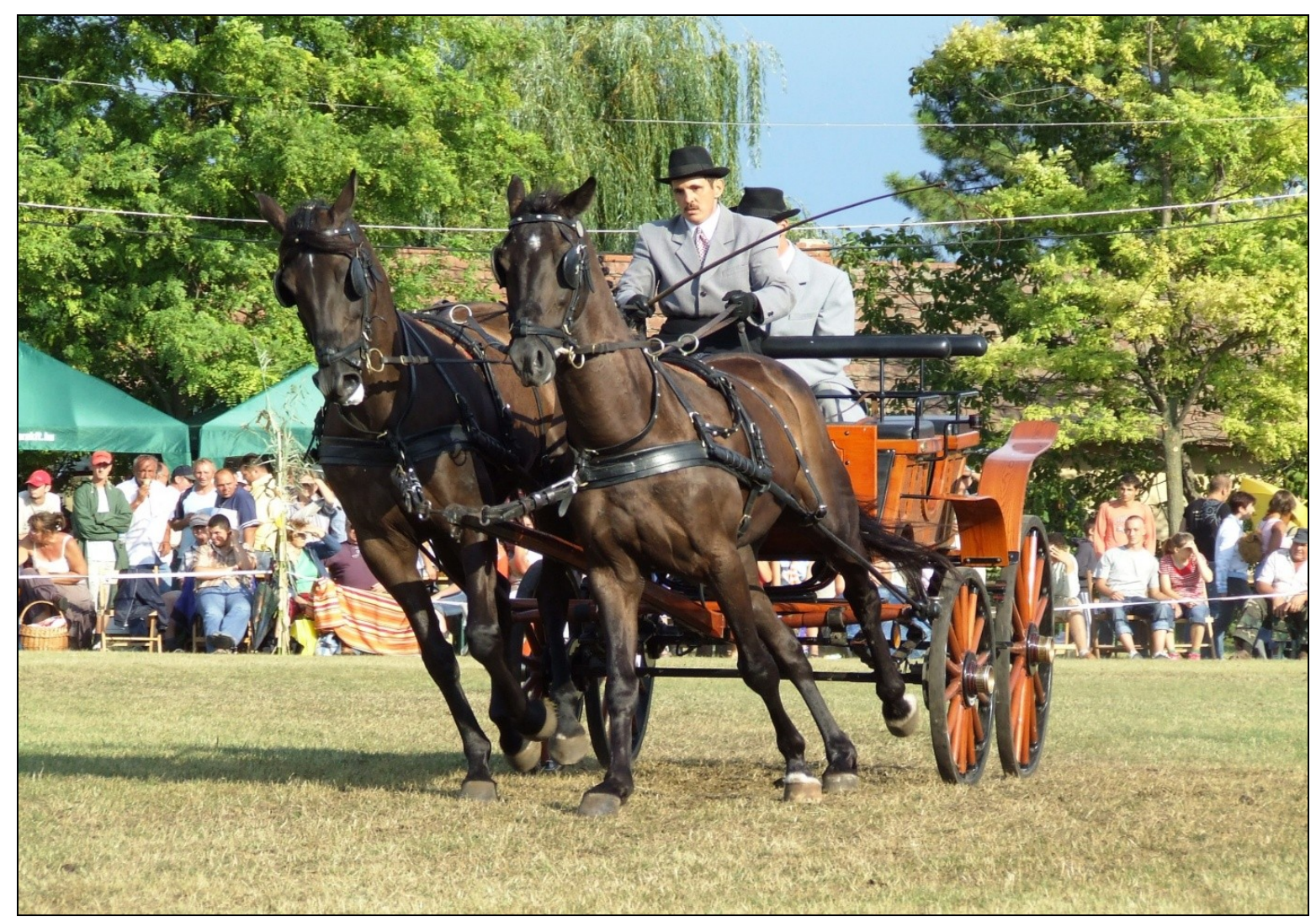

Fogathajtó verseny (Kondoros)

Forrás: MT Zrt.

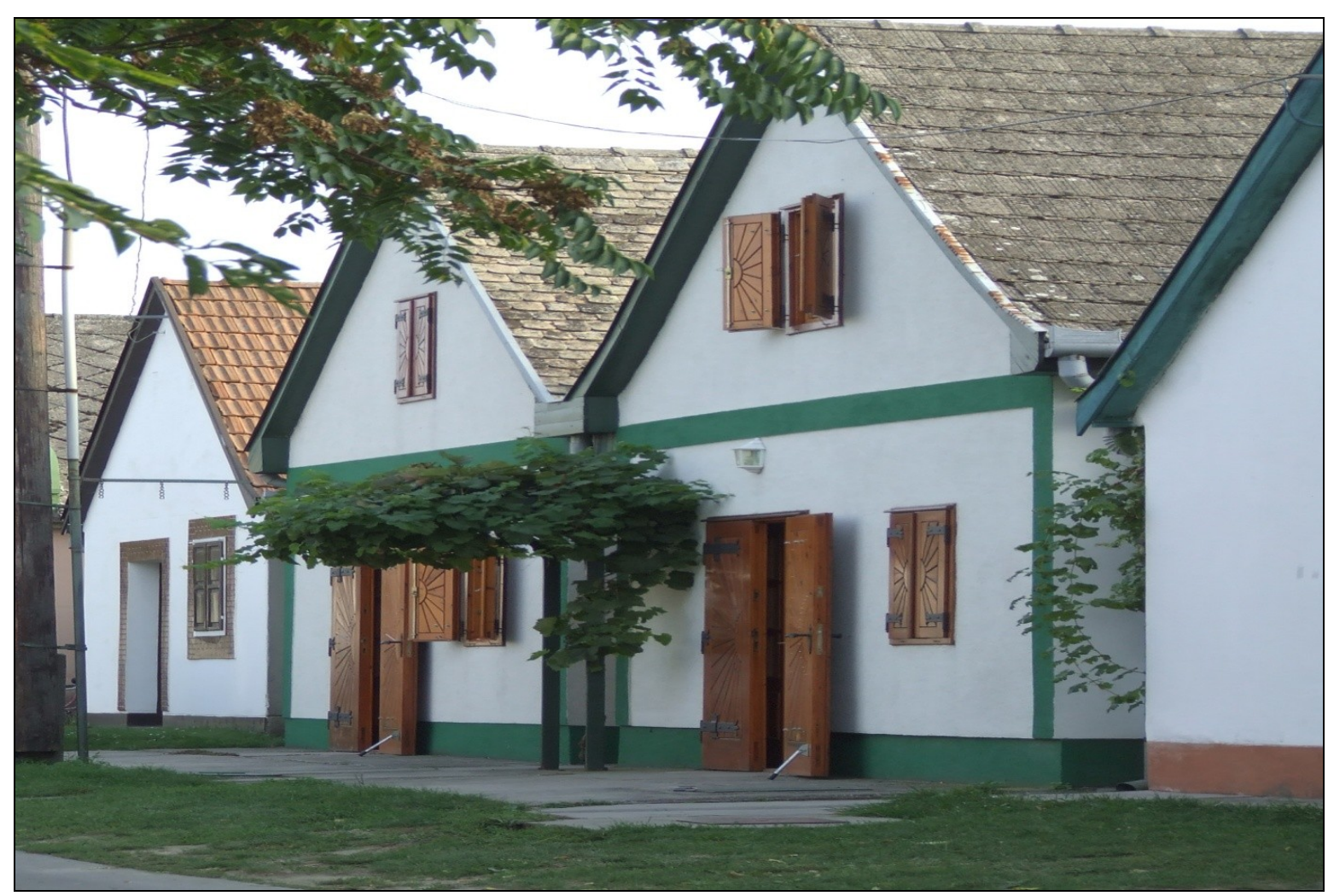

Hajós-Pincefalu

Forrás: MT Zrt. 


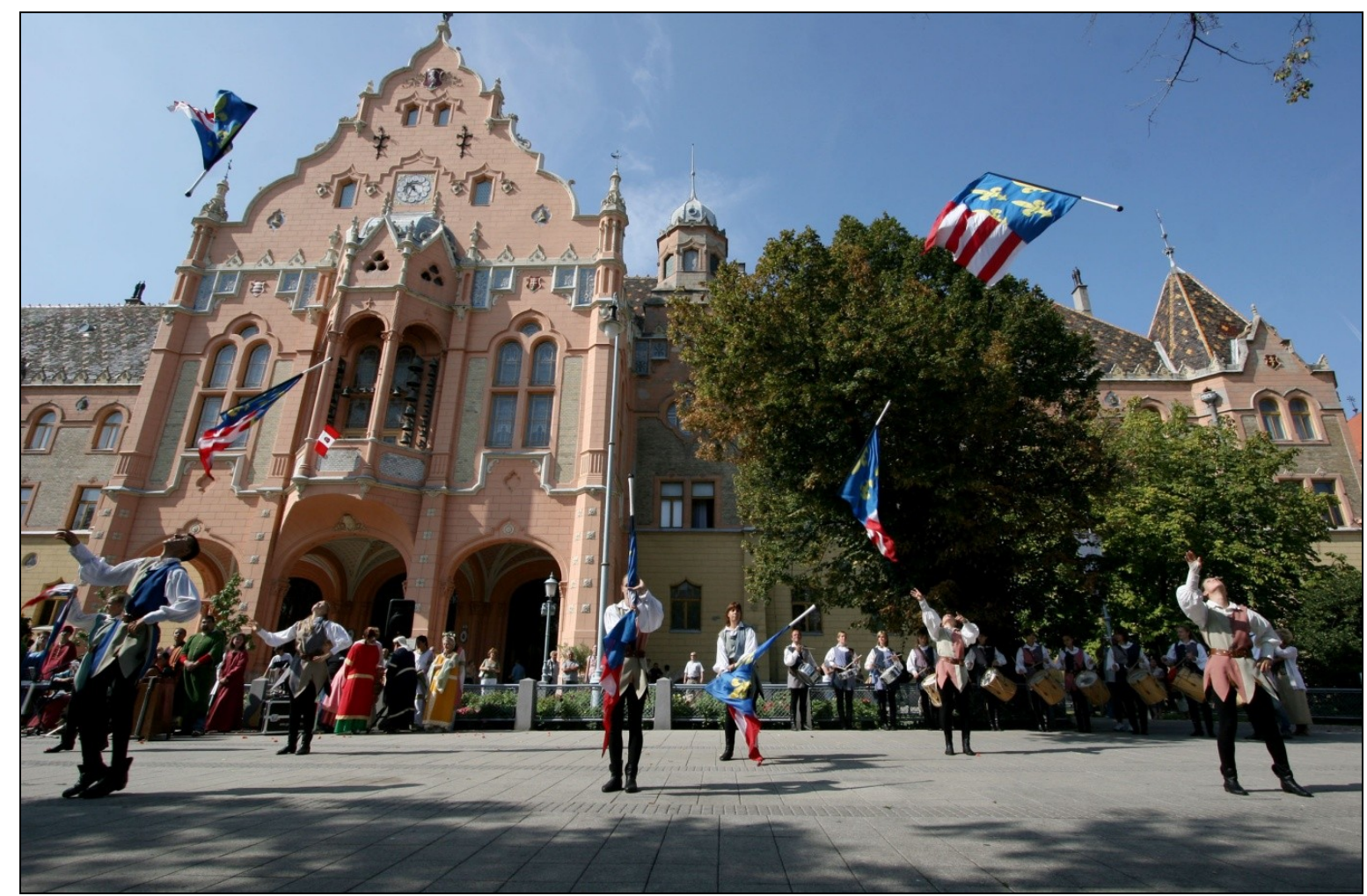

Hírös Hét Fesztivál (Kecskemét)

Forrás: MT Zrt.

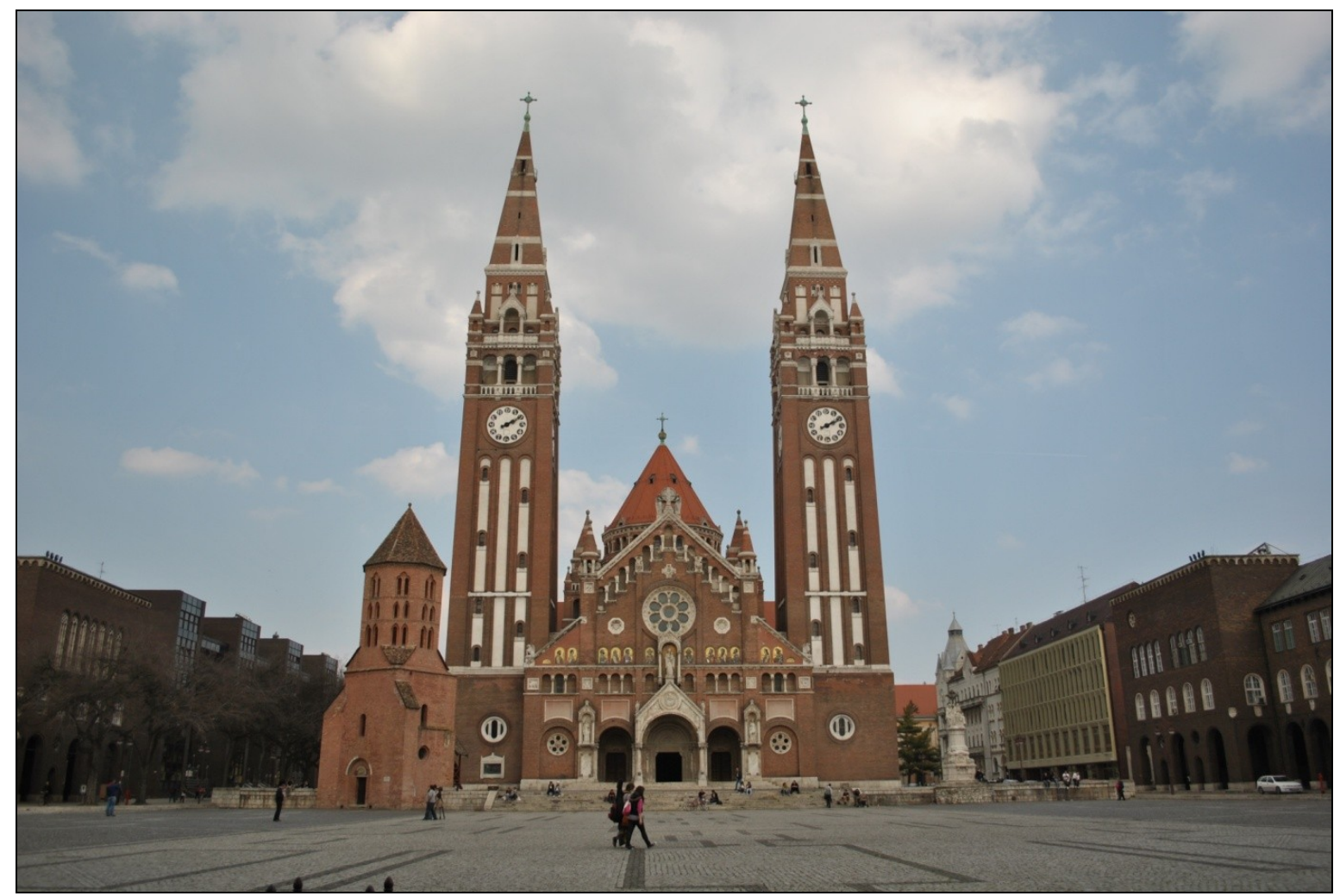

Magyarok Nagyasszony Fogadalmi Templom (Dóm) (Szeged)

Forrás: MT Zrt. 


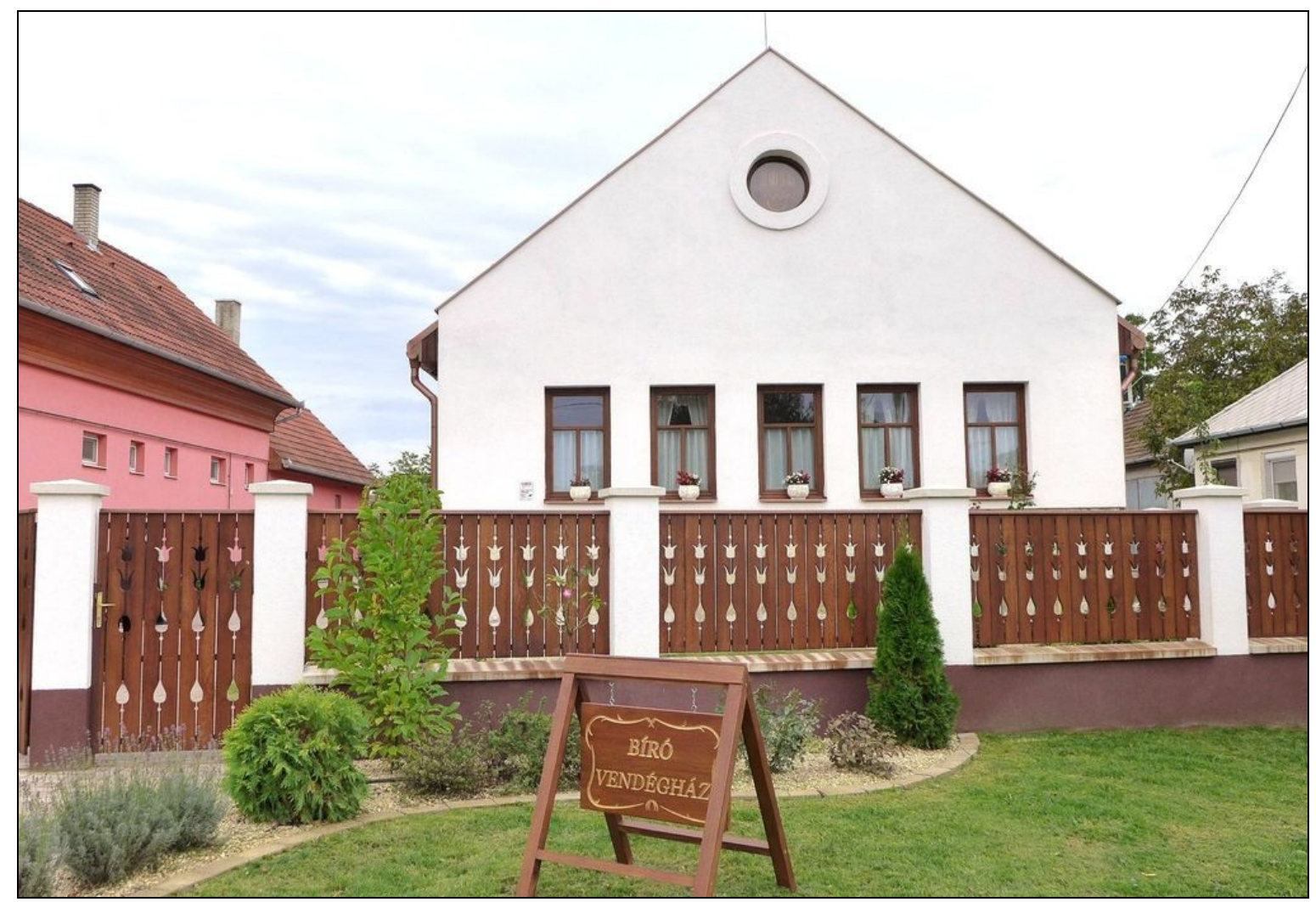

Bíró Vendégház (Jánkmajtis): Az ezredik Napraforgós Nemzeti Tanúsító Védjegy tulajdonosa

Forrás: www.turistanet.hu

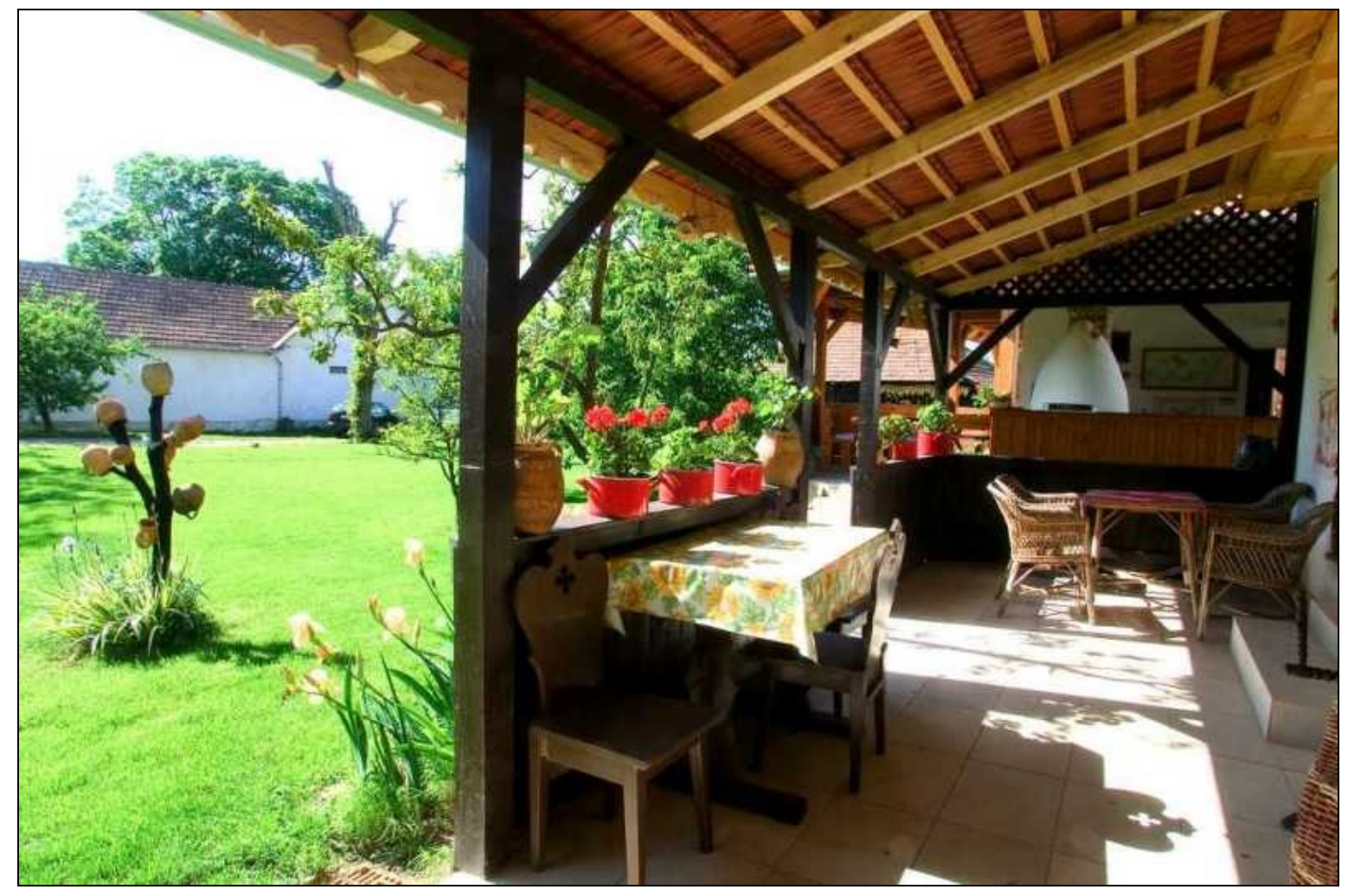

Danó Porta (Tivadar)

Forrás: www.danoporta.hu 


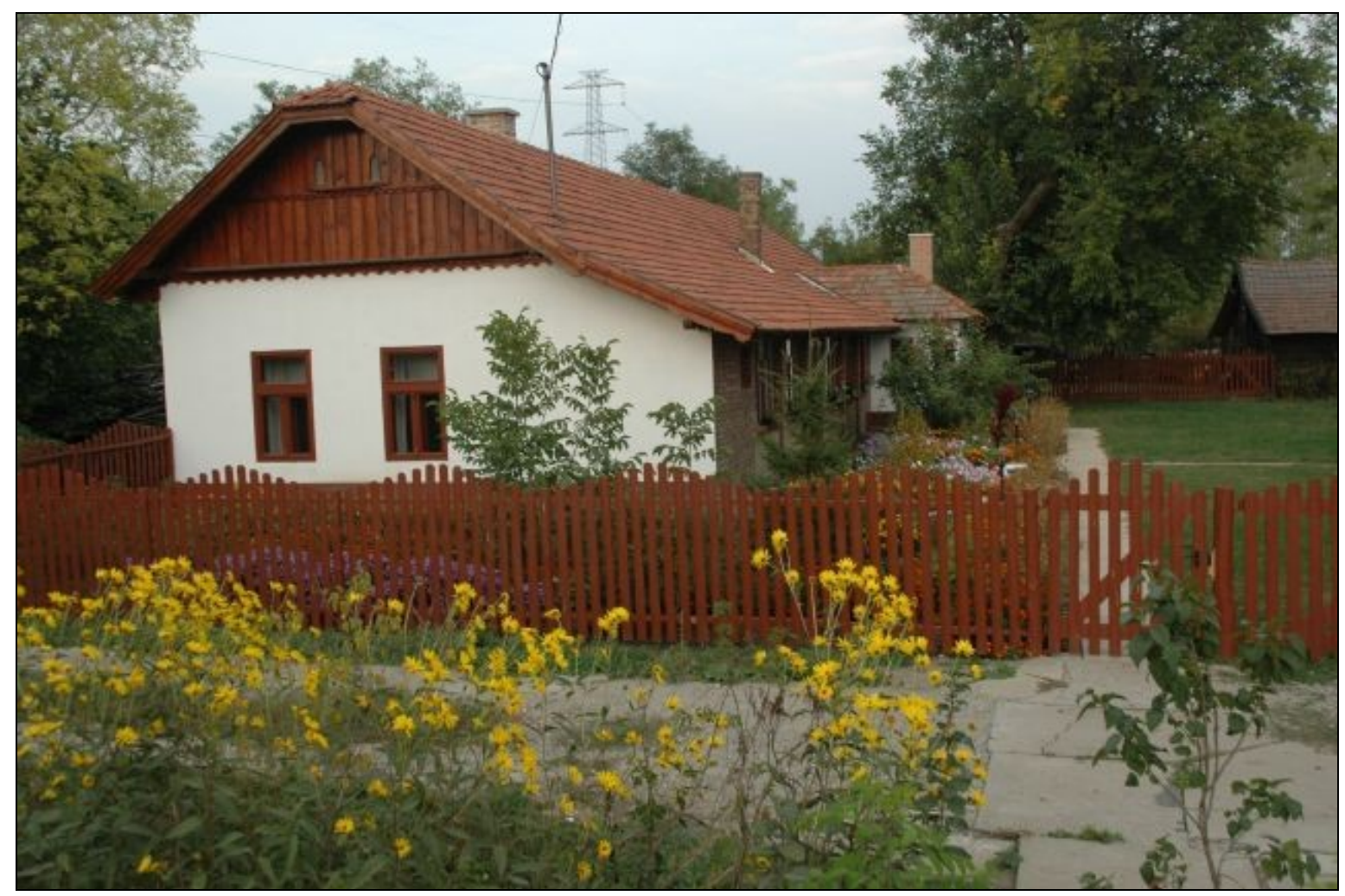

Eszter tanya (Csorvás)

Forrás:www.esztertanya.hu

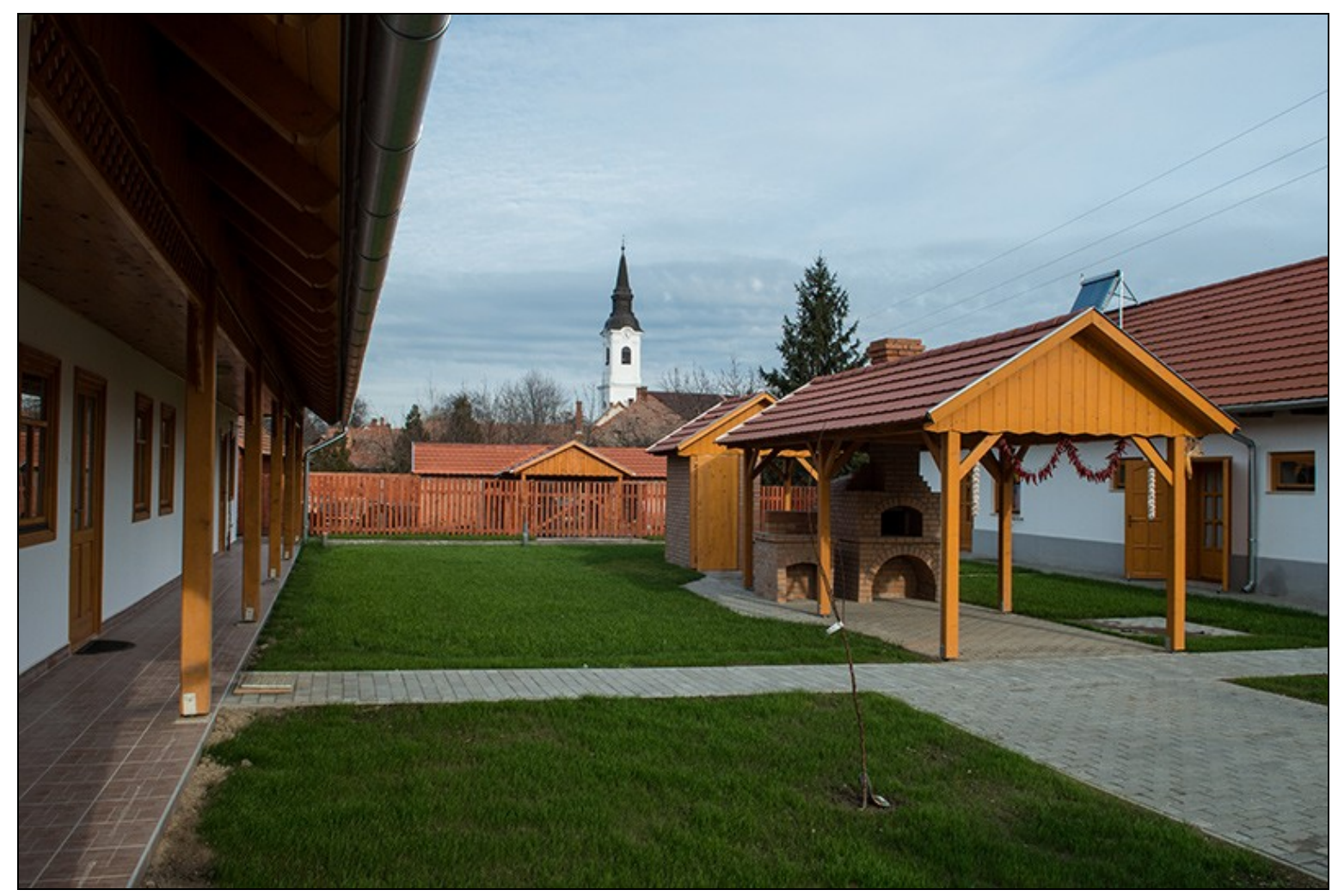

Bodor porta (Doboz)

Forrás: www.bodorporta.hu 


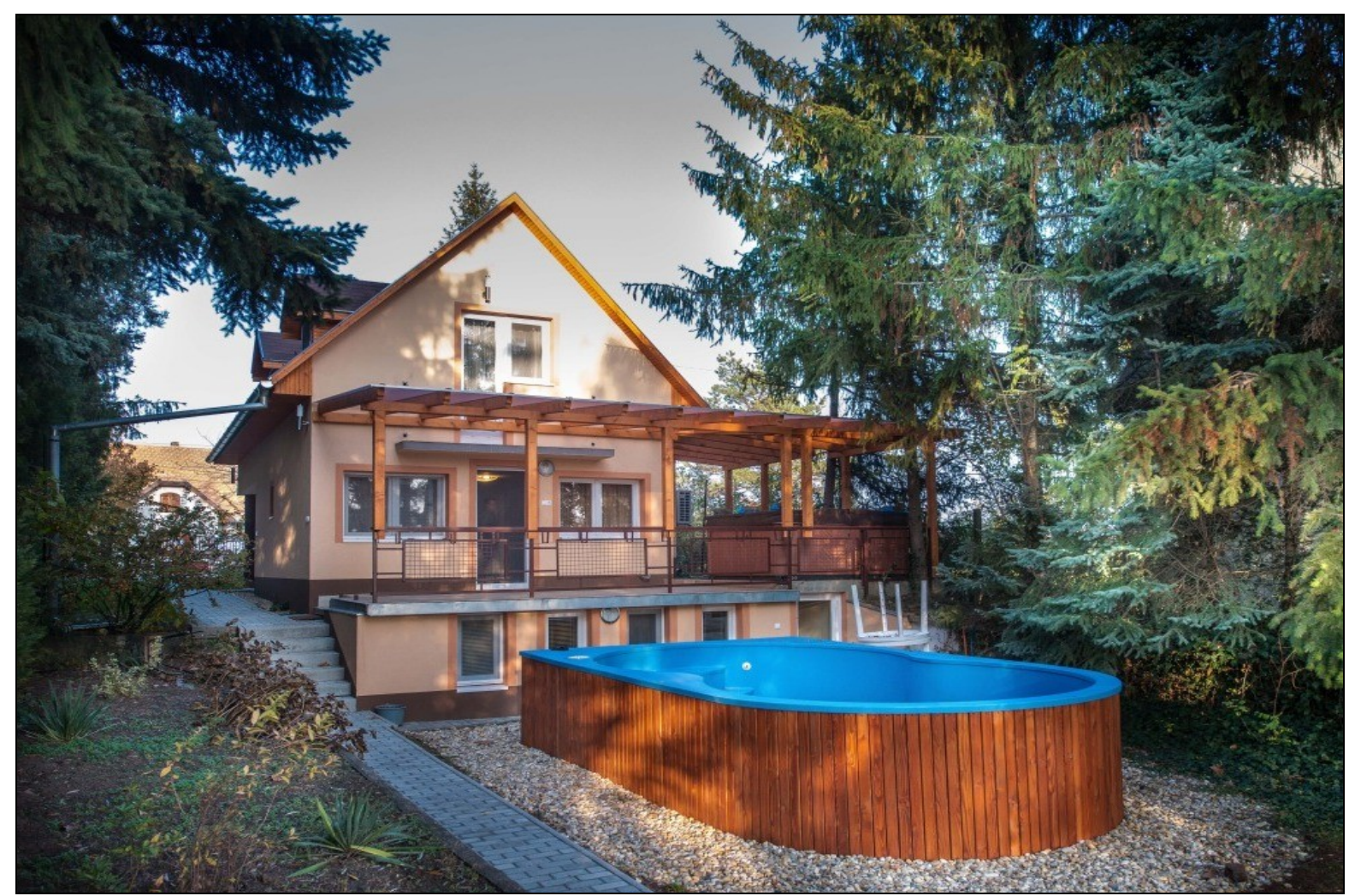

\section{Öregpacás Vendégház (Békésszentandrás)}

Forrás: oregpecas.uw.hu

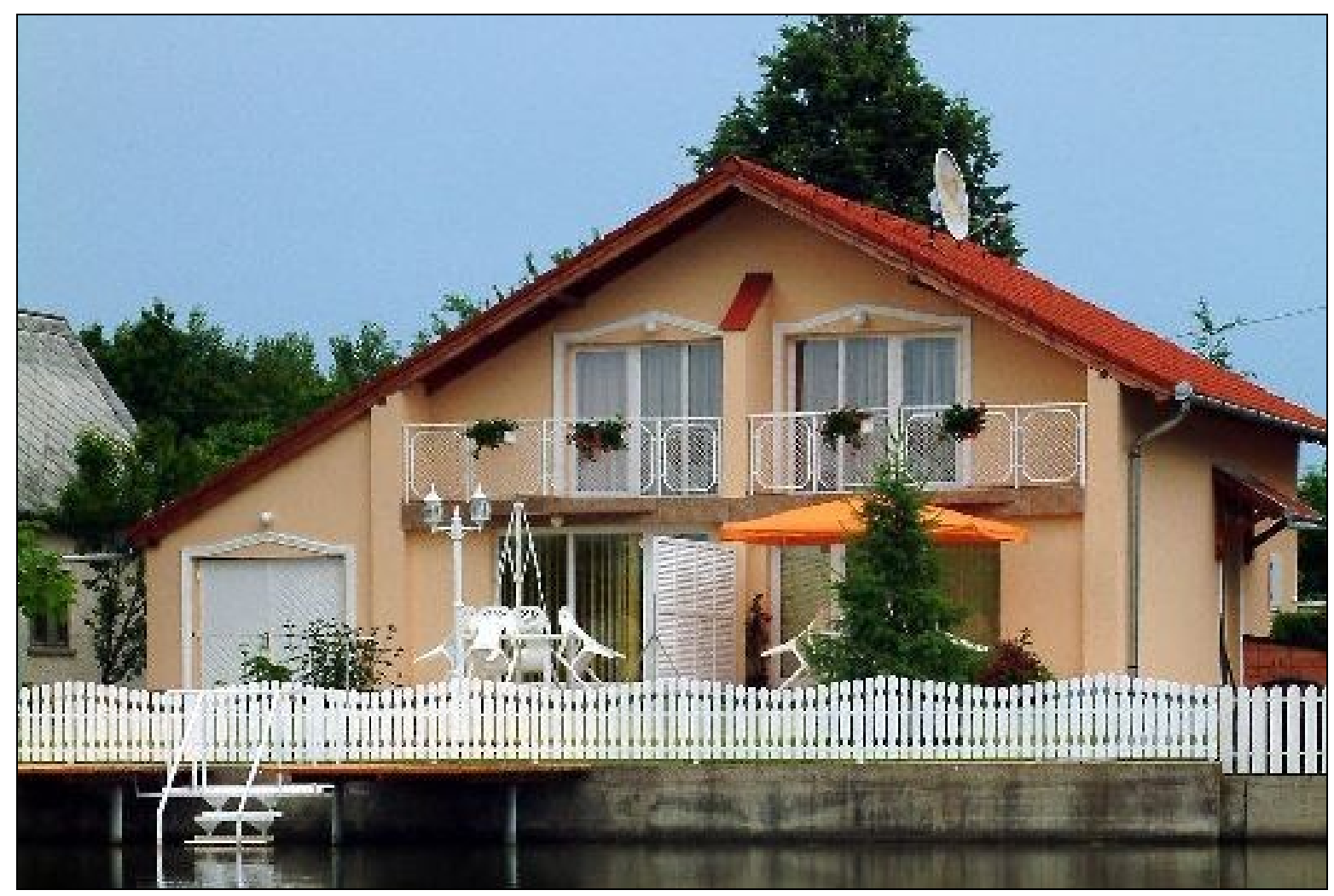

Kiszely nyaraló (Békésszentandrás)

Forrás: www.kiszelynyaralo.hu 


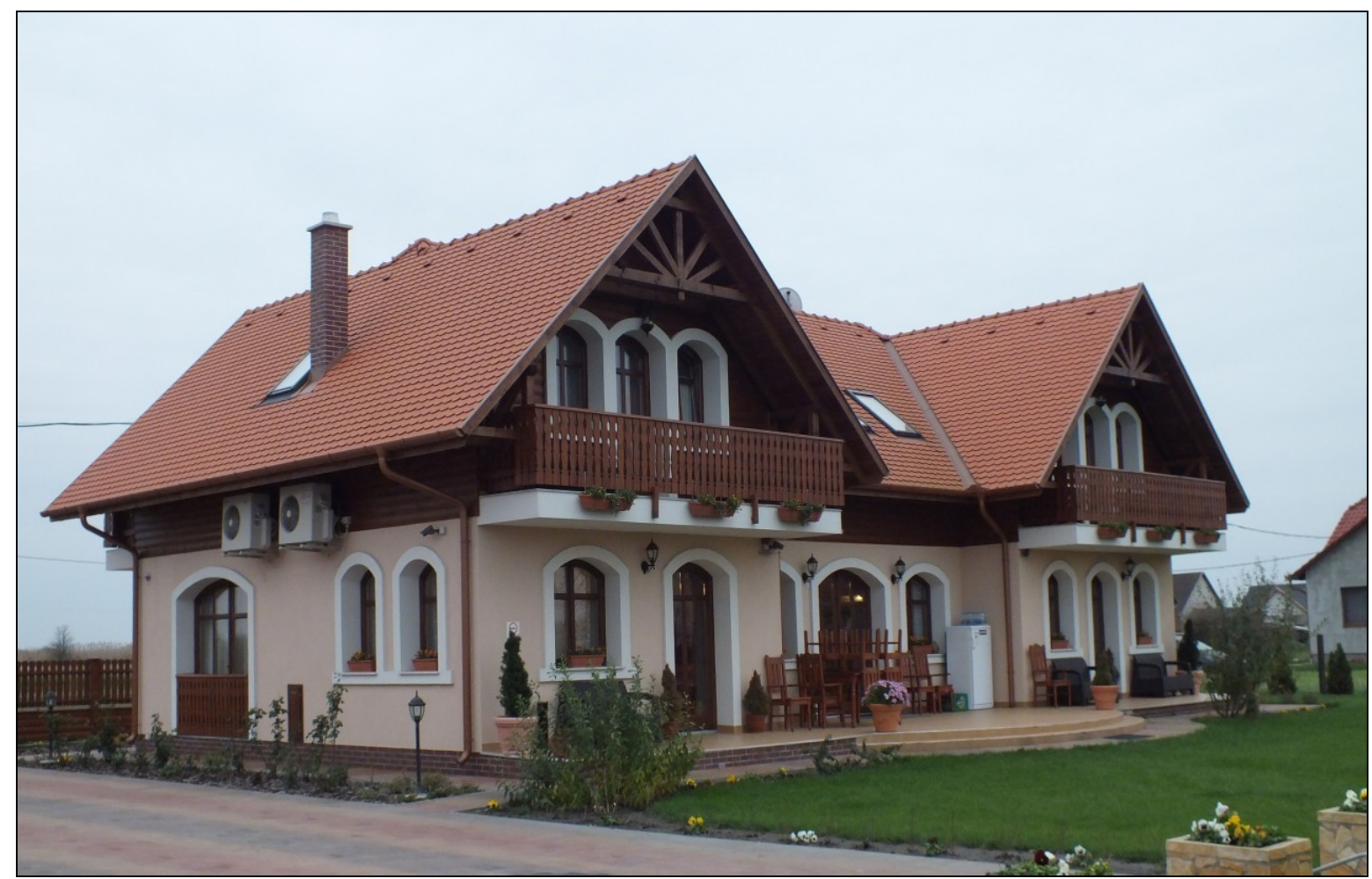

Sóvirág Vendégház (Hortobágy)

Forrás: www.soviragvendeghaz.hu

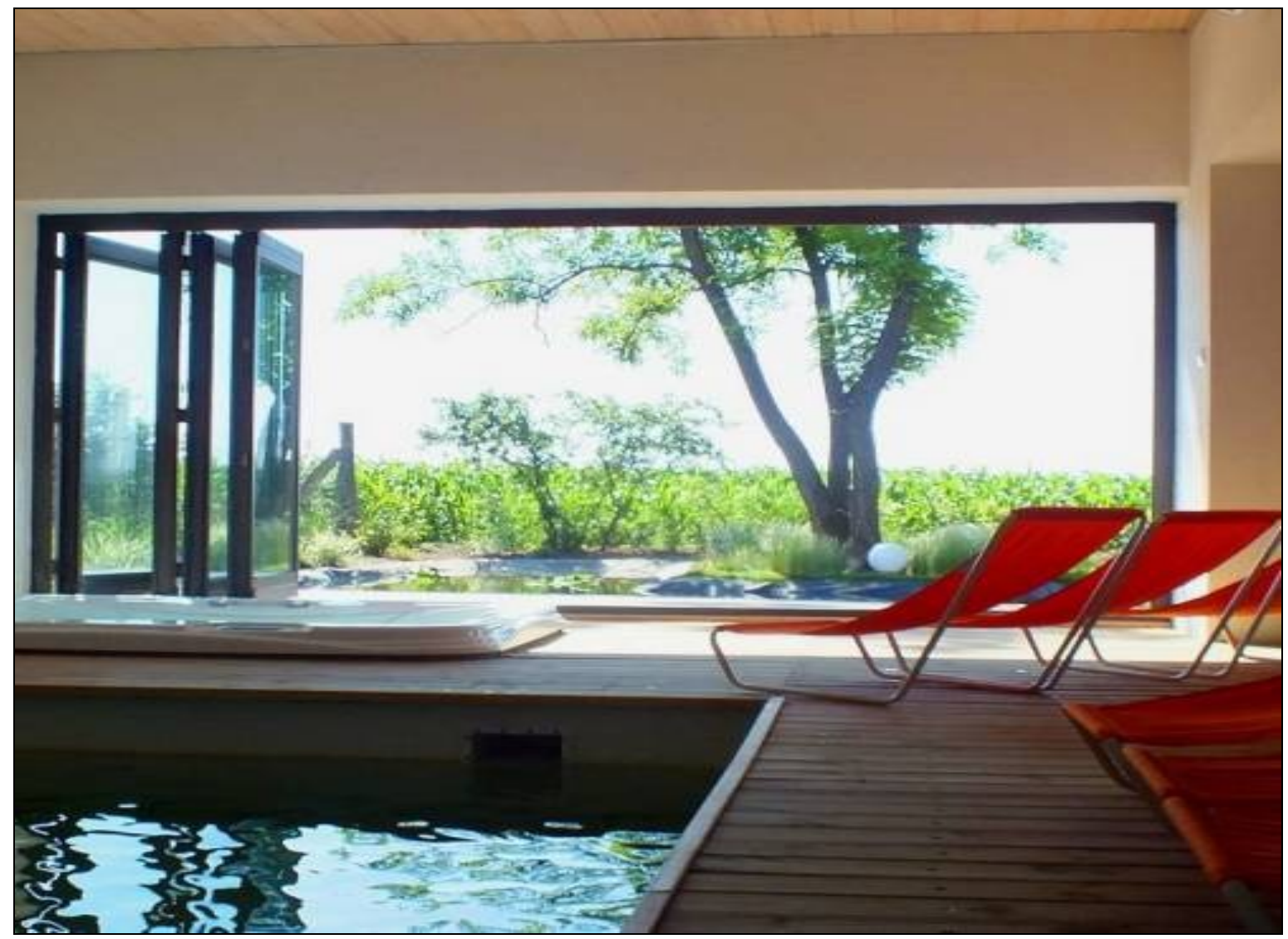

Héthatár Wellness Tanya (Pusztavacs)

Forrás: www.hethatar.net 


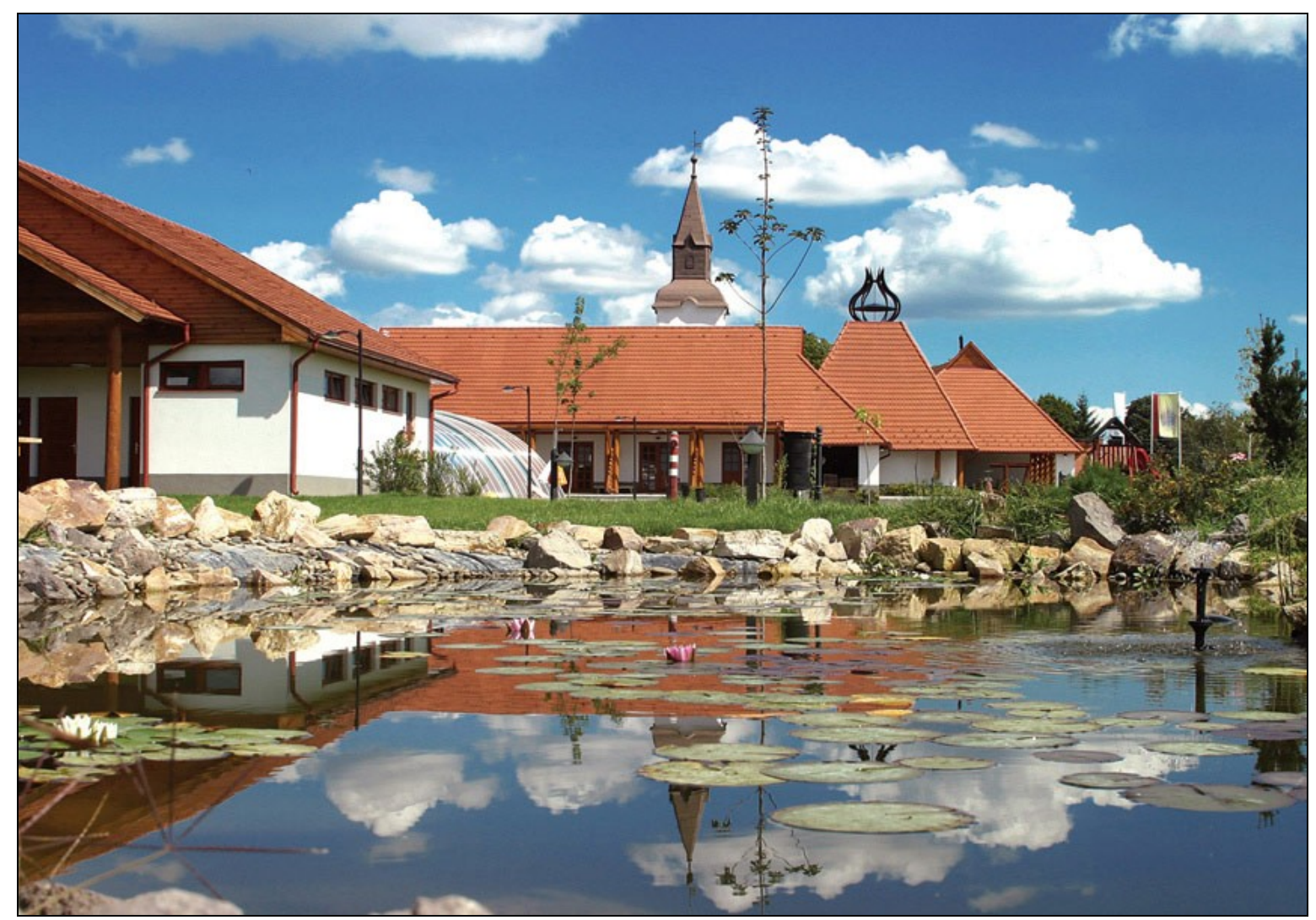

Hét Csillag Konferencia Központ (Beregdaróc)

Forrás: www.hetcsillag.hu

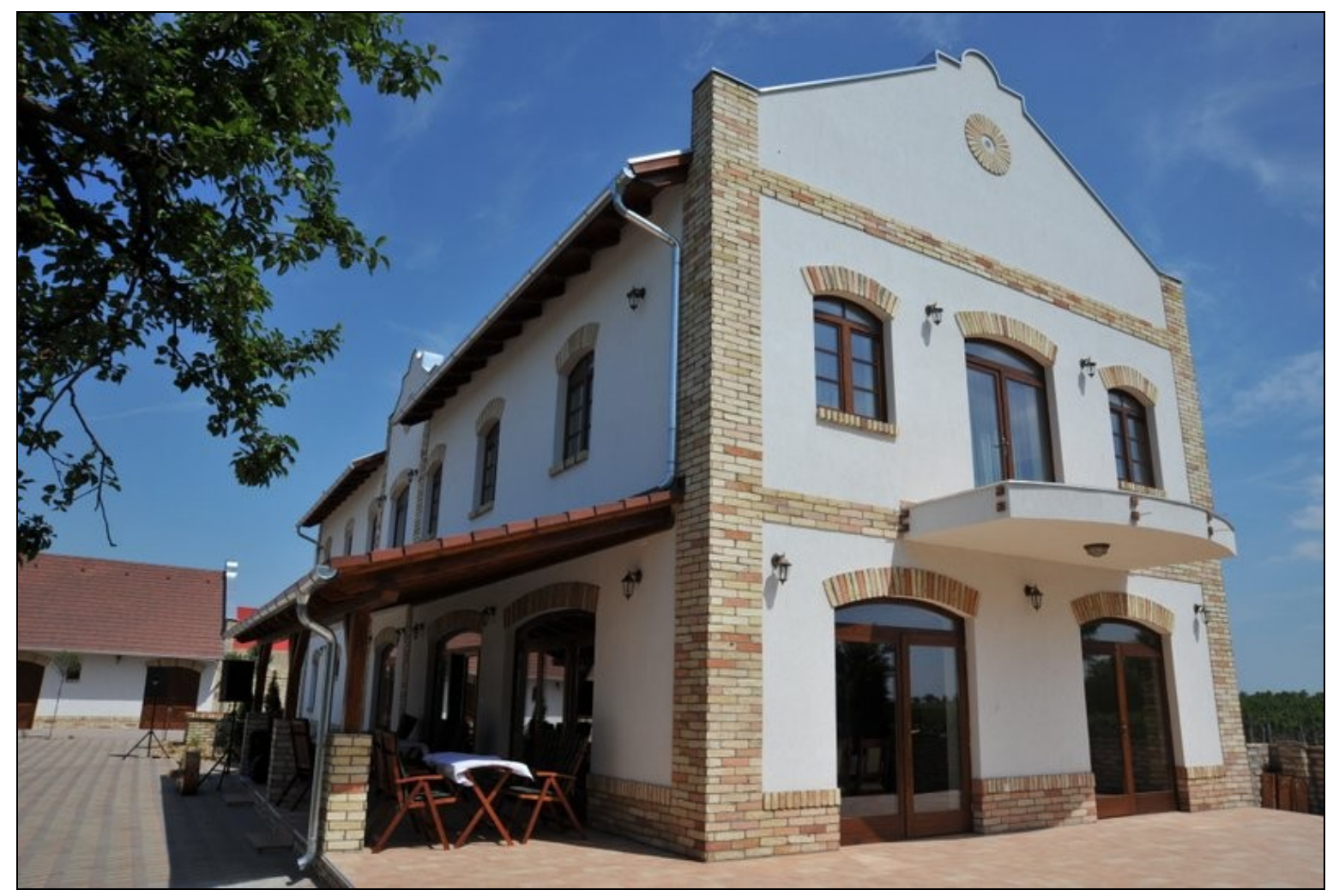

Koch Borház (Borota)

Forrás: www.kochboraszat.hu 


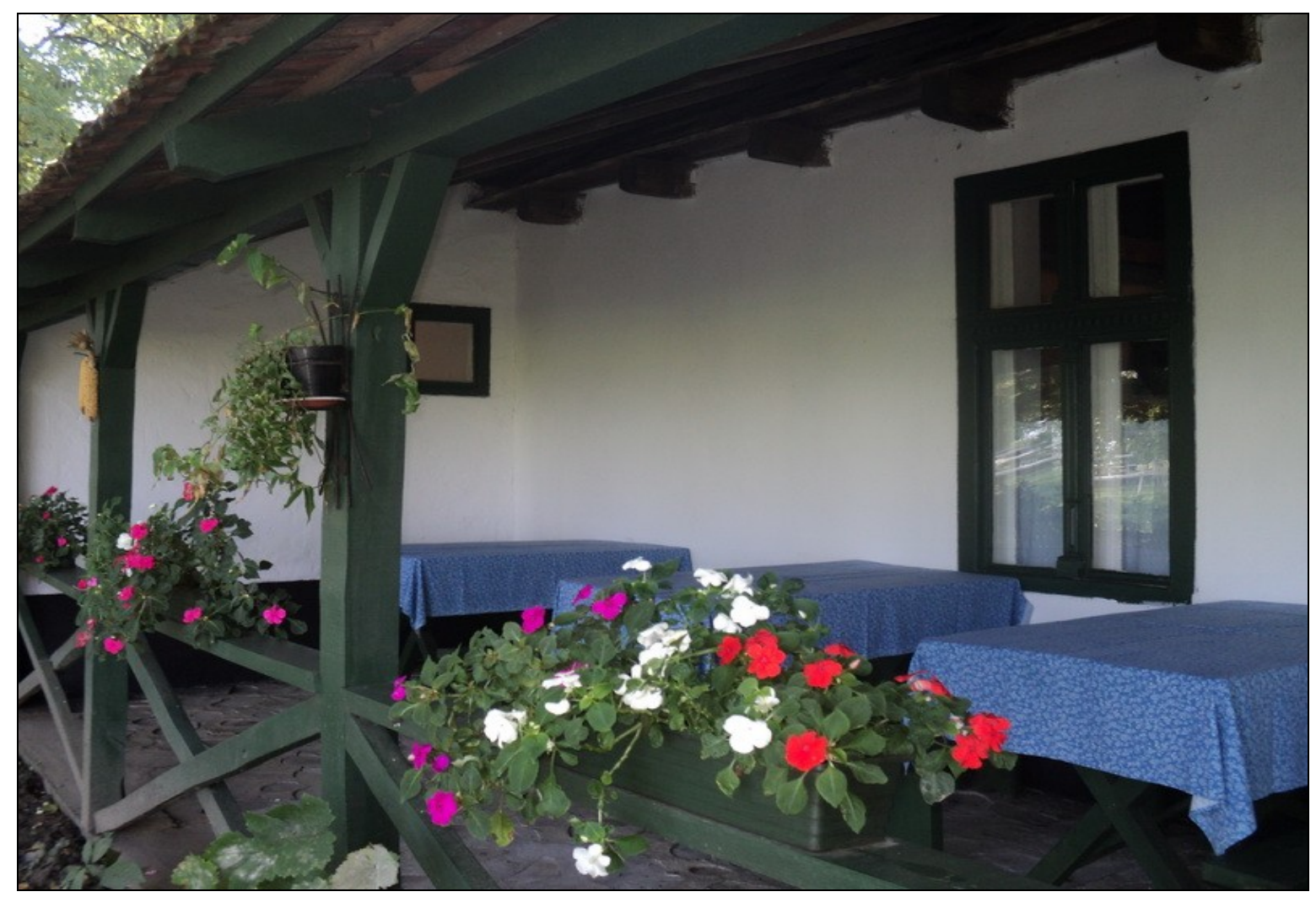

Steigerwald Tanya (Gyula)

Forrás: www.steigerwaldtanya.hu

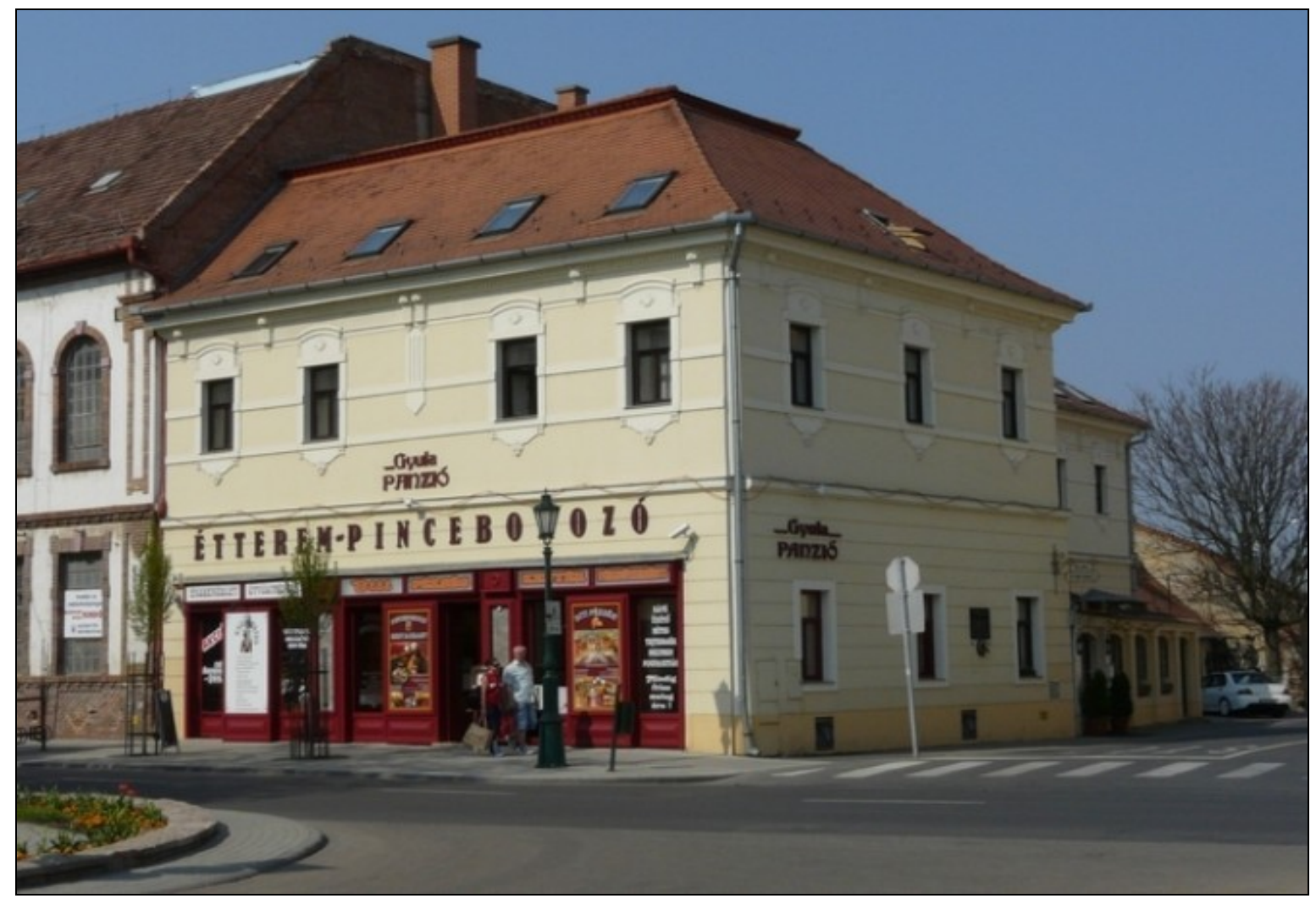

Gyula Panzió (Gyula)

Forrás: www.gyulapanzio.hu 


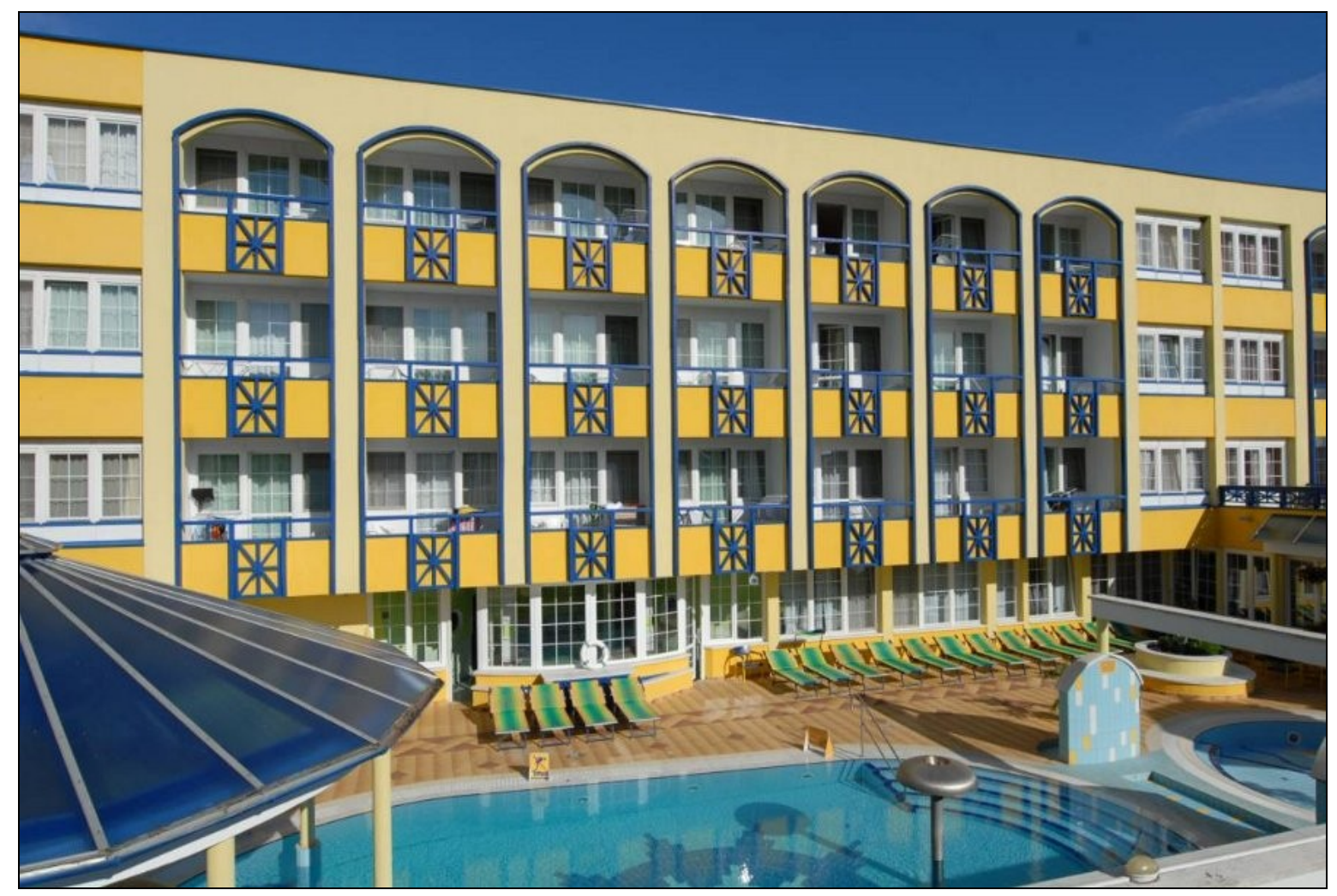

Rudolf Hotel (Hajdúszoboszló)

Forrás: www.hotelrudolf.hu

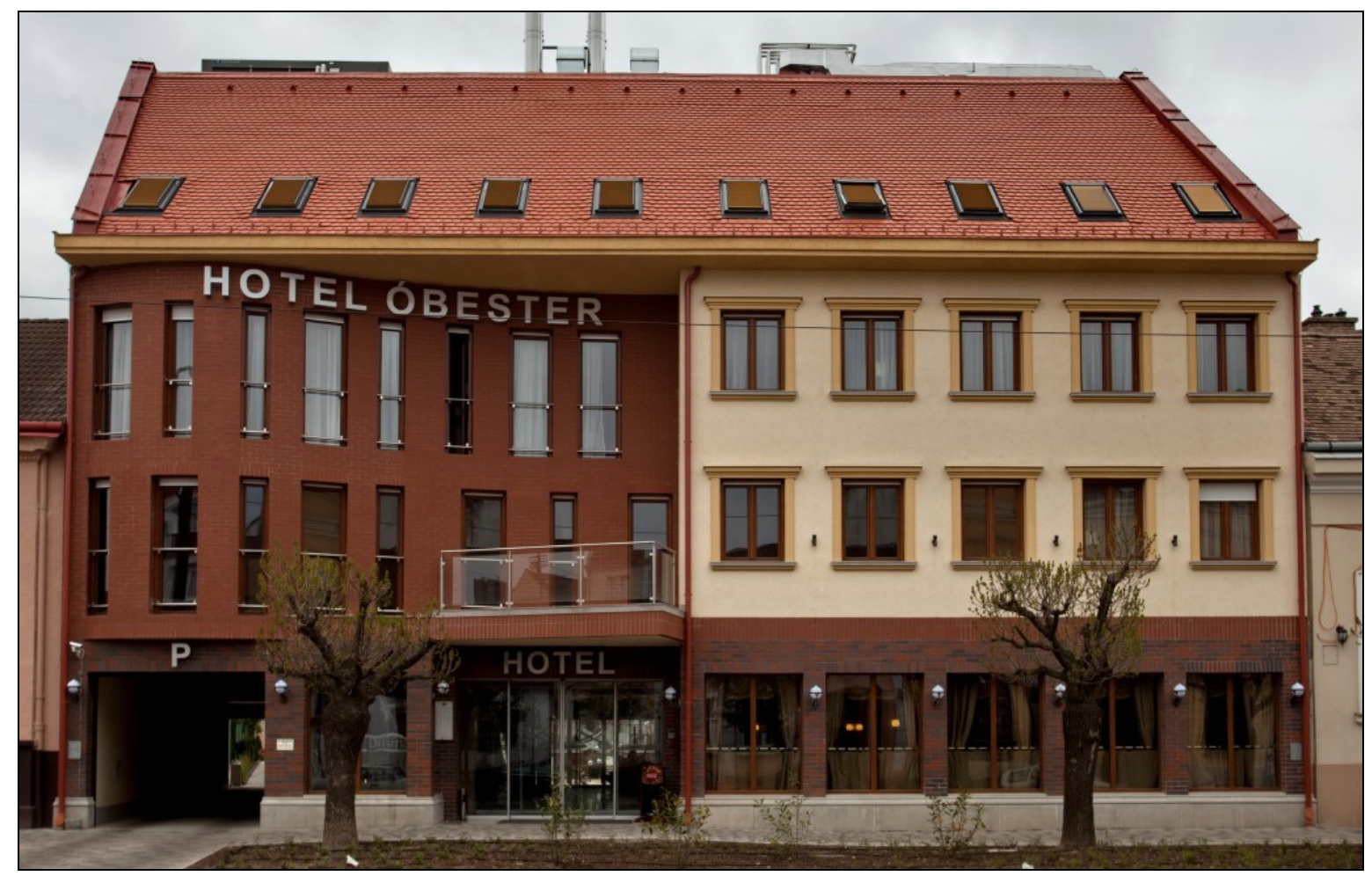

Hotel Óbester (Debrecen)

Forrás: www.hotelobester.hu 


\section{KÖSZÖNETNYILVÁNÍTÁS}

Köszönettel tartozom témavezetőmnek, Dr. Csatári Bálintnak szakmai segítségéért, hasznos tanácsaiért és kritikai észrevételeiért, melyekkel értekezésem elkészítését mindvégig támogatta.

Köszönetet mondok tovább mindazoknak, akik nyomon követték munkámat, szakmai észrevételeikkel, baráti biztatásukkal segítették munkámat.

Köszönettel tartozom családomnak a sok türelemért és megértésért, mellyel dolgozatom elkészítését lehetővé tették. 